IVAN BOLIS

CONTRIBUIÇÕES DA ERGONOMIA PARA A MELHORIA DO TRABALHO E PARA O PROCESSO DE EMANCIPAÇÃO DOS SUJEITOS 
IVAN BOLIS

\section{CONTRIBUIÇÕES DA ERGONOMIA PARA A MELHORIA DO TRABALHO E PARA O PROCESSO DE EMANCIPAÇÃO DOS SUJEITOS}

Dissertação apresentada à Escola Politécnica da Universidade de São Paulo para obtenção do titulo de Mestre em Engenharia 


\section{IVAN BOLIS}

\section{CONTRIBUIÇÕES DA ERGONOMIA PARA A MELHORIA DO TRABALHO E PARA O PROCESSO DE EMANCIPAÇÃO DOS SUJEITOS}

Dissertação apresentada à Escola Politécnica da Universidade de São Paulo para obtenção do titulo de Mestre em Engenharia

Área de Concentração:

Engenharia de Produção

Orientador: Prof. Dr. Laerte Idal Sznelwar 
FICHA CATALOGRÁFICA

Bolis, Ivan

Contribuições da ergonomia para a melhoria do trabalho e para o processo de emancipação dos sujeitos. / I. Bolis --- São Paulo, 2011. $179 \mathrm{p}$.

Dissertação (Mestrado) - Escola Politécnica da Universidade de São Paulo. Departamento de Engenharia da Produção.

1.Ergonomia 2. Condições de trabalho 3.Satisfação no trabalho I.Universidade de São Paulo. Escola Politécnica. Departamento de Engenharia de Produção II.t. 


\section{AGRADECIMENTOS}

Agradeço primeiramente a minha família. Uma lembrança muito especial vai para minha "nonna" Nina, pelo exemplo que deixou e pelo grande carinho que sempre mostrou para mim. Aos meus pais pela compreensão da minha escolha profissional e para o grandíssimo apoio desinteressado.

Ao Prof. Laerte Idal Sznelwar pela paciência ao longo da construção do trabalho e pelos preciosos conselhos.

Aos Professores Marcia Terra da Silva e Selma Lancman, pelas sugestões e contribuições valiosas.

A Isabelle, Soraya, Tamires e Alessandra pelo grande apoio no desenvolvimento do trabalho e pela essencial ajuda linguística.

Aos colegas de pós-graduação, sobretudo da sala de TTO, pela convivência, apoio e amizade.

E aos profissionais do Hospital Universitário da USP os quais me acolheram gentilmente e contribuíram de modo essencial para que este trabalho fosse possível. 


\section{RESUMO}

Esta dissertação foi idealizada a partir da busca de elementos que permitissem a introdução de melhorias duradouras e de maior porte nas organizações através da ergonomia.

Os principais objetivos foram, primeiro, analisar os benefícios do desenvolvimento de ações ergonômicas em um nível mais elevado da organização e mais próximo àqueles que a gerenciam. Posteriormente, descrever e analisar os benefícios da presença de trabalhadores com um alto grau de emancipação em uma intervenção ergonômica.

Como referencial teórico partimos da introdução da temática da ergonomia do trabalho, passando pela questão da emancipação no trabalho, e enfim pelo assunto da participação do trabalhador sob a ótica das teorias organizacionais.

Um projeto de pesquisa ação numa instituição pública da área da saúde se constituiu um meio útil para o levantamento dos dados, obtidos sobretudo através de entrevistas semi-estruturadas e da participação efetiva do pesquisador nos processos de implantação dos dispositivos de melhoria. Em uma primeira parte foi avaliado e analisado o trajeto das ações ergonômicas desenvolvidas na instituição em estudo, enquanto na segunda parte dos resultados foi analisado o grau de envolvimento dos trabalhadores no processo de melhoria na organização em um nível mais abrangente da instituição.

Este trabalho permitiu concluir que um papel proativo dos sujeitos visando uma efetiva transformação do trabalho pode propiciar resultados positivos e duradouros em intervenções ergonômicas, assim como é fundamental para a construção de um processo de emancipação dos trabalhadores (em vários níveis da organização). Fortemente relacionada à conclusão anterior é a confirmação de que quanto mais elevamos a discussão e quanto maior o apoio em níveis elevados de decisão sobre a ergonomia na hierarquia organizacional, maior é o sucesso na implementação de políticas de melhoria. 
Palavras chave: Ergonomia participativa, Emancipação do trabalhador, Macroergonomia, Organização do trabalho. 


\begin{abstract}
The aim of this dissertation was to look for elements that allow organizations to introduce important and lasting improvements through ergonomics.

Two main strategic goals have been pursued during this work. The first aim analyzes the benefits of ergonomics developed on high levels of organization, closer to managers. The second, instead, investigates the importance of a presence of workers with an high degree of emancipation within ergonomic approaches.

From a theoretical point of view, the starting point consists of the introduction, in the working system, of ergonomic themes, worker emancipation and worker participation (analyzed within organization theories).

The practical results have been achieved through an action research project applied to a public care organization. The outcomes were achieved mainly through the adoption of semi-structured interviews and the participation of the researcher during the processes of improvement implementation. First of all, the course of ergonomic actions developed in the institution under study have been evaluated and examined. Then the research focused on the degree of employee involvement in this process of improvement in a larger scale.

This study revealed that a proactive role carried out by people looking for an effective transformation of the work provides positive and lasting results within an ergonomic intervention. At the same time this is fundamental to build a process of emancipation of workers in the different levels of organization. Therefore, on the basis of this conclusion, the more ergonomics is applied to higher levels of discussions and decisions in the organization hierarchy, the greater the success in implementing improvement policies is.
\end{abstract}

Keywords: Participatory Ergonomics, Workers Emancipation, Macroergonomics, Work organization. 


\section{LISTA DE ILUSTRAÇÕES}

Ilustração 1 - Esquema geral da abordagem AET ........................................................17

llustração 2 - Modelo de duas dimensões produtividade-ergonomia...................................25

llustração 3 - Participantes aconselhados para o Comitê de Ergonomia...............................27

llustração 4 - Formas de interação entre conhecimento tácito e conhecimento explicito. ....41

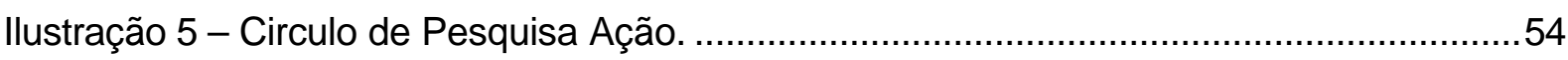

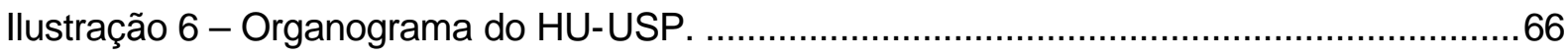

Ilustração 7 - Distribuição etária de 2005 a 2009............................................................68

Ilustração 8 Dificuldade ergonômicas verbalizadas pelos gestores......................................88

llustração 9 - Problemas ergonômicos com equipamentos..............................................100

Ilustração 10 - Presencia de compras que deram problemas............................................101

llustração 11 - Cuidado com a temática da ergonomia durante um pedido de compra. .....103

llustração 12 - Necessidade de ajuda externa em considerar aspectos ergonômicos nas

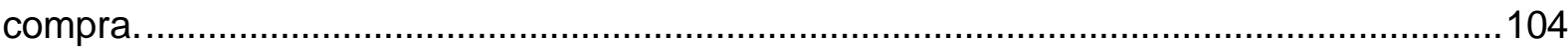

Ilustração 13 - Respostas de quem poderia dar suporte por questões ergonômicas na hora

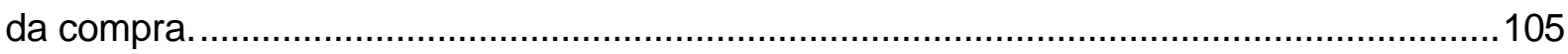

llustração 14 - Dificuldades dos gestores na hora da compra de equipamentos...............109

llustração 15 - Posicionamento dos sujeitos que atuam na organização entre nível de decisão na organização e conhecimento do trabalho operacional.

llustração 16 - Posicionamento das ações ergonômicas desenvolvidas no HU-USP entre nível de decisão na organização e potencial de melhorias.

Ilustração 17 - Movimento descendente e ascendente na organização para a

implementação eficaz de políticas de melhoria.

Ilustração 18 - Variáveis com aumento "linear" ao aumento do grau de emancipação.......126

Ilustração 19 - Relação entre expectativas e resultados positivos.....................................127

llustração 20 - Variáveis com aumento "não linear" ao aumento do grau de emancipação.

Ilustração 21 - Tipologia de sucesso com diferentes graus de emancipação dos trabalhadores e diferentes níveis da organização aonde se situa a discussão ergonômica. 


\section{LISTA DE TABELAS}

Tabela(s) 1 - Número de acidentes fatais no trabalho e número de lesões e doenças ocupacionais nos EUA.

Tabela 2 - Dados sobre funcionários com restrições e afastamentos a longo prazo no HUUSP.

Tabela 3 - Respostas agregadas dos participantes do comitê de melhorias. 74

Tabela 4 - Tipologia de trabalhadores participantes do GTC. 75

Tabela 5 - Grau de voluntariedade dos participantes do GTC. 77

Tabela 6 - Conceitos aprendidos pelos participantes do GTC 78

Tabela 7 - Aplicação dos conhecimentos adquiridos pelos participantes do GTC. 80

Tabela 8 - Suporte da organização depois do curso no GTC. 82

Tabela 9 - Suporte da organização depois do curso no GTC, relacionado a outras variáveis.

Tabela 10 - Respostas de quem acha que o GTC tomou tempo demais deles. 84

Tabela 11 - Respostas de quem acha que o GTC teve um conjunto de participantes não ideal.

Tabela 12 - Respostas da pergunta feita aos gerentes sobre qual o objeto de estudos ergonômicos.

Tabela 13 - Respostas da pergunta feita aos gerentes sobre qual o objeto de estudos ergonômicos (em porcentagem).

Tabela 14 - Conhecimento de ações de tipo ergonômico pelos gestores - GTC.

Tabela 15 - Conhecimento de ações de tipo ergonômico pelos gestores - CM. 90

Tabela 16 - Relação entre as ações de ergonomia e melhoria nas condições de trabalho.

$(\mathrm{SR}=$ sem resposta)

Tabela 17 - Relação entre conhecimento do GTC e percepção de melhorias entre os gerentes.

Tabela 18 - Tipo de cuidado em assuntos ergonômicos em compras, por grupos de gestores.

Tabela 19 - Relação entre tipo de cuidado ergonômico, presença de problemas sobre a saúde do trabalhador e necessidade de ajuda externa na hora da compra de equipamentos. 
Tabela 20 - Relação ente tipo de cuidado ergonômico e quem respondeu da existência de problemas na falta de conhecimento ergonômico, no especificar e na falta de tempo. ........110

Tabela 21 - Relação ente tipo de cuidado ergonômico e quem respondeu da existência de problemas econômicos e no mercado na hora da compra de equipamentos.......................111

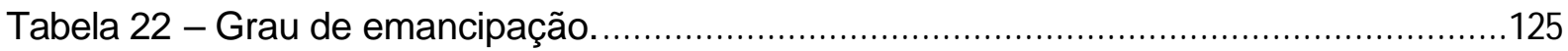




\section{SUMARIO}

1 - INTRODUÇÃO

1.1 - Contextualização do tema de Pesquisa..................................................................

1.2 - Formulação do problema - origem da pesquisa....................................................4

1.3 - Contextualização do projeto de pesquisa em ergonomia desenvolvido no HU-USP ..6

1.4 - Estrutura da dissertação...............................................................................11

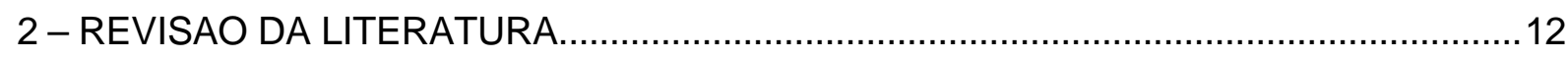

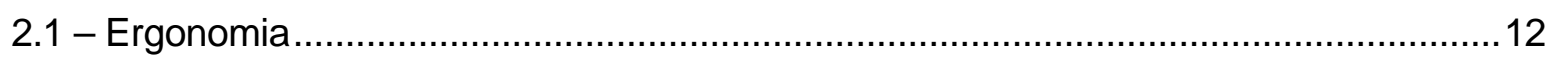

2.1.1 - Abordagem: Análise Ergonômica do Trabalho .................................................14

2.1 .2 - Evolução da ergonomia ......................................................................... 18

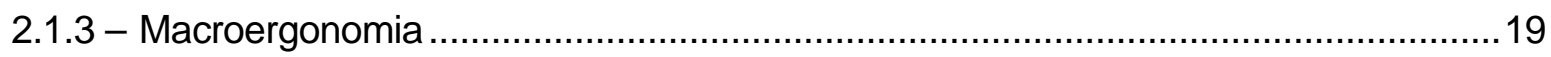

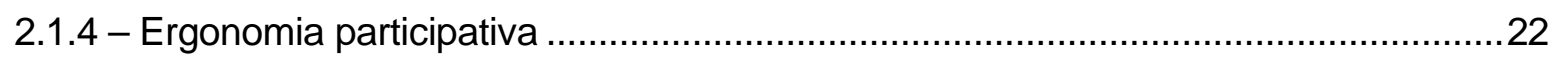

2.1.5 - A produtividade e os problemas levantados pela temática da ergonomia..............23

2.1.6 - Comitê multifuncional e de ergonomia..................................................................25

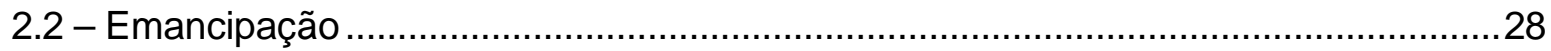

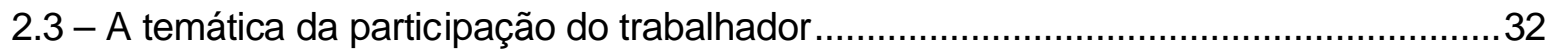

2.3.1 - A participação do trabalhador nas principais teorias da organização do trabalho..35

2.3.2 - Ação organizativa e a contribuição de Maggi .......................................................... 42

3 - PROPOSIÇÕES, OBJETIVOS E RELEVÂNCIA ..................................................... 45

3.1 - Visão dos pesquisadores sobre o trajeto de ações ergonômicas no HU-USP .......... 45

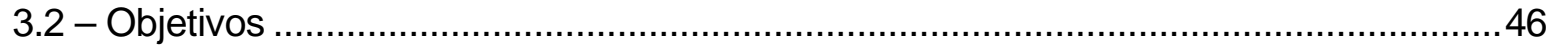

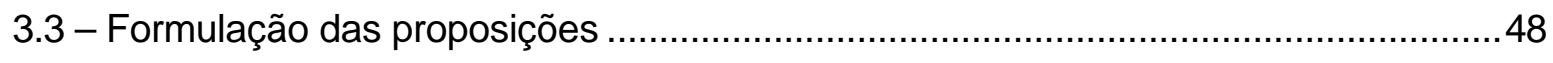

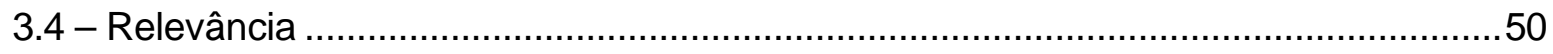

4 - ASPECTOS METODOLÓGICOS - PESQUISA AÇÃO .............................................. 51

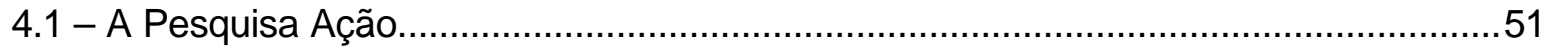

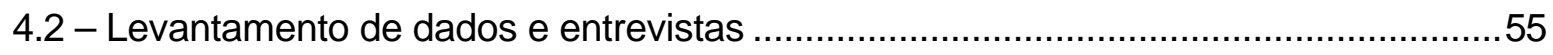

4.3 - Método: pesquisa ação no Hospital Universitário da USP .......................................59

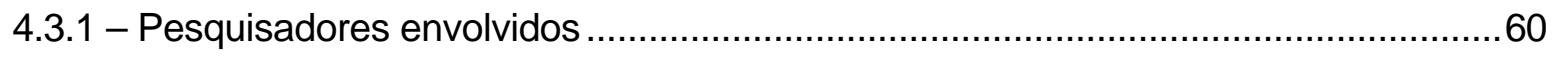

4.3.2 - Ciclos do projeto de pesquisa ação ..............................................................60

4.3.3 - Entrevistas semi-estruturadas no HU-USP .......................................................63

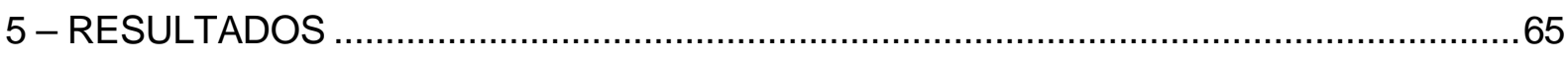

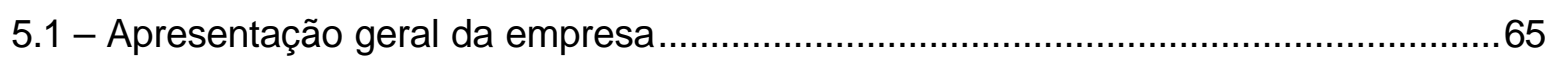

5.2 - Questão da saúde dos trabalhadores no HU-USP ..............................................66 
5.3 - Análise e crítica do trajeto de ações ergonômicas desenvolvidas na instituição em estudo e análise do grau de disseminação da ergonomia - avaliação . 69

5.3.1 - Comitê de melhorias (CM) 69

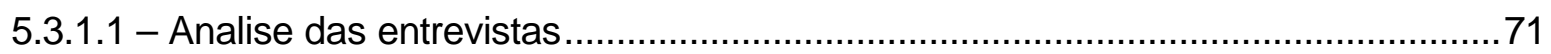

5.3.2 - Grupo de Treinamento e Capacitação (GTC) …................................................. 75

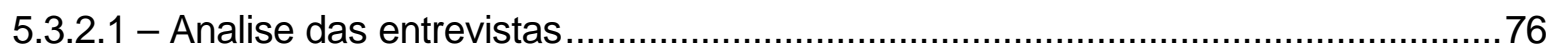

5.3 .3 - Disseminação de conceitos ergonômicos entre os gestores .................................86

5.3.4 - Visão do projeto de ergonomia por parte da direção da empresa - assessora ......93

5.3.5 - Visão do projeto de ergonomia por parte da direção da empresa - Superintendente .95

5.4 - Envolvimento dos trabalhadores no processo de melhoria na organização em nível estratégico (aplicação na seção das compras) - a questão das compras no HU-USP. .....98

5.4.1 - Entrevista com os gestores sobre ergonomia ligada às compras . . .99

5.4.2 - Envolvimento dos co-participantes do HU-USP na resolução do eixo da aquisição de materiais, equipamentos, sistemas de informação e serviços ...................................112

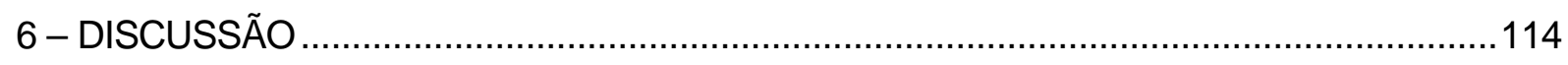

6.1 - Analise do sucesso ou insucesso dos projetos de ergonomia no HU-USP .............114

6.2 - Benefícios em elevar a temática da ergonomia no nível estratégico da organização 120

6.3 - Benefícios de um papel proativo dos trabalhadores em vários níveis da organização numa intervenção ergonômica .............................................................................. 124

6.4 - O papel do Comitê de Melhorias ......................................................................... 131

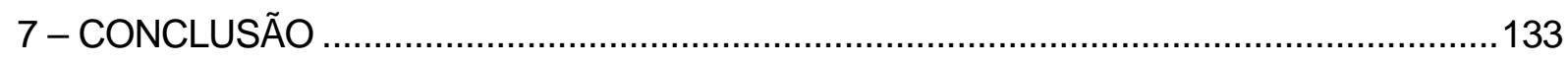

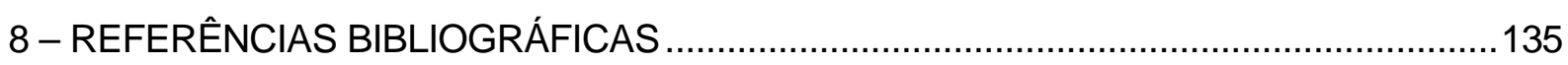

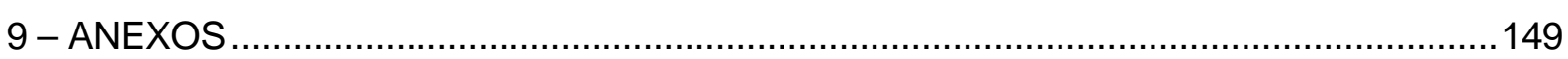




\section{1 - INTRODUÇÃO}

\section{1 - Contextualização do tema de Pesquisa}

Problemas de saúde dos trabalhadores criam prejuízos econômicos às empresas. Um estudo do National Institute for Occupational Safety and Health (2009) identificou como os empregadores dos EUA perdem entre \$13 e \$20 milhões de dólares cada ano por diminuição de produtividade e outras queixas ligadas à saúde.

Além das empresas, existem grandes custos também para os países. No Brasil, por exemplo, segundo os dados do Ministério da Previdência Social (2010a) se considerados exclusivamente o pagamento dos benefícios devido a acidentes e doenças do trabalho somado ao pagamento das aposentadorias especiais decorrentes das condições ambientais do trabalho em 2008, o INSS tem que gastar por volta de $R \$ 11,60$ bilhões/ano. Se forem adicionadas despesas como o custo operacional do INSS e as despesas na área da saúde, o custo ligados a saúde no trabalho atinge no Brasil o valor da ordem de $R \$ 46,40$ bilhões/ano. Estas estatísticas levam em consideração exclusivamente os custos econômicos, mas a estes precisaríamos adicionar os impactos sociais. No Brasil, em 2007, ocorreu cerca de uma morte decorrente do trabalho a cada 3 horas, e 23 trabalhadores a cada dia que não retornaram ao trabalho por invalidez.

Entendendo as conseqüências e os custos causados por problemas de saúde no trabalho, nos países desenvolvidos estão sendo hoje implementadas políticas adequadas. Este é o caso, por exemplo, dos EUA, visível nos dados apresentados nas tabelas 1 que mostram uma grande diminuição seja no número de acidentes fatais para o trabalhador como no número de lesões e doenças ocupacionais (nos seis anos de análise houve uma diminuição em $24,91 \%$ nos casos identificados).

A situação do Brasil segue contra esta tendência. Com base nos dados do DIESAT Departamento Intersindical de Estudos e Pesquisa de Saúde e dos Ambientes de Trabalho (2010) em um período de seis anos (de 2001 a 2007) houve um aumento dos acidentes de trabalho em 91,94\%. 


\begin{tabular}{|c|c|} 
Ano & $\begin{array}{c}\text { Numero de acidentes fatais no } \\
\text { trabalho }\end{array}$ \\
\hline $\mathbf{2 0 0 3}$ & 5575 \\
\hline $\mathbf{2 0 0 4}$ & 5764 \\
\hline $\mathbf{2 0 0 5}$ & 5734 \\
\hline $\mathbf{2 0 0 6}$ & 5840 \\
\hline $\mathbf{2 0 0 7}$ & 5657 \\
\hline $\mathbf{2 0 0 8}$ & 5214 \\
\hline $\mathbf{2 0 0 9}$ & $4340(\mathrm{P})$ \\
\hline
\end{tabular}

\begin{tabular}{|c|c|}
\hline Ano & $\begin{array}{c}\text { Numero de lesões e doenças } \\
\text { ocupacionais (milhares) }\end{array}$ \\
\hline $\mathbf{2 0 0 3}$ & 4365.2 \\
\hline $\mathbf{2 0 0 4}$ & 4257.3 \\
\hline $\mathbf{2 0 0 5}$ & 4214.2 \\
\hline $\mathbf{2 0 0 6}$ & 4085.4 \\
\hline $\mathbf{2 0 0 7}$ & 4002.7 \\
\hline $\mathbf{2 0 0 8}$ & 3696.1 \\
\hline $\mathbf{2 0 0 9}$ & 3277.7 \\
\hline
\end{tabular}

Tabela(s) 1 - Número de acidentes fatais no trabalho e número de lesões e doenças ocupacionais nos EUA.

Fonte: Extraído do Bureau of Labor Statistics (2010).

Entrando no detalhe dos dados da Previdência Social (2010), referentes ao Estado de São Paulo, as profissões mais perigosas não são as atividades ligadas à construção civil, ao combate ao crime, ou em profissões operacionais que tenham contato com o uso de produtos tóxicos, como comumente poderíamos pensar; nos anos entre 2006 e 2008 os trabalhadores do atendimento hospitalar tiveram a maior quantidade de acidentes do estado, com um aumento em dois anos de $29,91 \%$ dos casos. Em comparação com todas as atividades desenvolvidas em São Paulo, médicos, enfermeiros, técnicos e auxiliares de enfermagem e os demais funcionários representam $6,89 \%$ de todos os acidentes ocorridos no ano de 2008 , chegando quase na quantidade somadas das três sucessivas atividades como maior número de afastamentos (administração pública em geral, fabricação de açúcar em bruto e comércio varejista de mercadorias em geral com predominância de produtos alimentícios e hipermercados). Um número tão significativo pode ser explicado também por causa de uma fiscalização mais intensa em tais lugares, mas de qualquer maneira identifica a necessidade de uma grande atenção da ergonomia sobre este tipo de atividade.

Além dos problemas de saúde relacionados ás atividades de trabalho, nos últimos anos discute-se sempre mais a questão do aumento da idade média dos trabalhadores, com as relativas conseqüências sobre a prestação do trabalho e a saúde dos mesmos.

O envelhecimento é hoje um fenômeno universal, característico sobretudo dos países desenvolvidos, mas presente também naqueles em via de desenvolvimento. 
Com referência nos dados da Organization for Economic Co-operation and Development - OECD (2010), no Brasil a população com idade inferior aos 15 anos, passou de 29,6\% em 2000, á 26,36\% em 2000, enquanto a projeção em 2030 é de ficar em $17 \%$. Inversamente, a população com mais de 65 anos passou de $5,49 \%$ em 2000, a 6,58\% em 2008, e projetada a 13,65\% em 2030. Tal fenômeno na população em geral, se reflete também num envelhecimento na população de trabalhadores. Com foco na força de trabalho dos servidores públicos do Brasil, um estudo realizado pela OECD a pedido do Ministério do Planejamento (2010) mostrou como $40 \%$ dos servidores públicos federais têm mais de 50 anos. Pode-se extrair também que o serviço público no Brasil está envelhecendo rapidamente mais do que o mercado de trabalho.

Segundo vários estudos (SANDERS e McCORMICK, 1993; AVOLIO e WALDMAN, 1994; VERHAEGEN e SALTHOUSE, 1997; VOORBIJ e STEENBEKKERS, 2000; BUGAJSKA, 2005), capacidades físicas e cognitivas diminuem quando as pessoas ficam mais idosas, tendo conseqüências no ato do trabalho. Isso acarreta um grande desafio para as empresas, na preservação da saúde dos trabalhadores.

Existem várias disciplinas que cuidam da relação entre saúde e trabalho, mas com a presente dissertação o autor quis exclusivamente focalizar o seu estudo na contribuição da disciplina da ergonomia. Embora esta contribuição para a saúde e segurança nem sempre seja reconhecida (JENKINS e RICKARDS, 2001), as empresas associam este campo de conhecimento a problemas da saúde e aos custos relacionados com as faltas por doenças, sendo que a demanda por análises ergonômicas deriva quase exclusivamente de tal motivação. Existem, mas são poucos, os casos nos quais a ergonomia é associada à eficácia organizativa. Como escrito por Dul e Neumann (2009) a ergonomia pode contribuir nas estratégias das companhias, seja no nível das funções de negócio como no nível intra-funcional e no nível corporativo.

Com a presente dissertação, partindo de problemas ligados á saúde dos trabalhadores, o autor quis ampliar a temática da ergonomia a aspectos da organização do trabalho, tentando elevar a discussão num nível da organização (e de poder) mais elevado e considerando os benefícios de um envolvimento proativo de funcionários. 


\section{2 - Formulação do problema - origem da pesquisa}

A pesquisa origina-se partindo de um estudo anterior, um trabalho de formatura realizado pelo autor (BOLIS, 2007). Em tal trabalho foi desenvolvida uma aplicação prática da metodologia da Análise Ergonômica do Trabalho - AET (a ser explicada no capítulo da revisão da literatura) em um dos departamentos mais críticos de uma empresa hospitalar, devido à presença de muitos acidentes de trabalho.

A aplicação da metodologia AET permitiu chegar a um diagnóstico composto por uma lista de sugestões de melhorias aplicáveis tanto na parte da adaptação da estrutura física como no remodelamento de alguns processos de trabalho. Por limites de tempo e pelo fato que de acordo com os planos estratégicos da organização ocorreria o deslocamento físico do departamento pesquisado daí a alguns meses, não foi possível para o autor chegar até a fase da implementação do diagnóstico. Permanecendo em contato com a instituição e voltando após dois anos foram percebidas poucas mudanças efetivas, por ter sido dada maior prioridade a projetos de outras áreas. Além disso, embora a divulgação gradual de conceitos de ergonomia em todos os níveis da organização feita por parte de todo o grupo de pesquisa, após varias ações e sem outras ajudas externas o hospital teve dificuldades para desenvolver independentemente novas ações ergonômicas.

As explicações para tal foram encontradas através de duas justificativas. A primeira é que as decisões de mudanças e os projetos são assuntos exclusivos da direção da instituição e os outros interlocutores para tais questões são os serviços especializados em segurança e medicina do trabalho e, sobretudo, os chefes de área. Estes últimos encontram muitas dificuldades para influenciar as decisões da instituição para que se incluíssem nos processos de decisão aspectos do trabalho que, apesar de terem conhecimento sobre os problemas, não o tinham de modo sistemático. Um dos aspectos que dificultam este tipo de atuação é que as chefias estão muito mais envolvidas em outros assuntos mais diretamente ligados à produção do serviço e ao seu próprio trabalho.

Em segundo lugar ficou claro, sobretudo nos estudos ergonômicos $A E T$, que estes foram de tipo descendente (top-down) dirigidas pelo pesquisador (ou seja, ele é a pessoa que tem o poder de decidir e dirigir a sua pesquisa sobre as situações e as 
pessoas envolvidas no estudo) o qual foi contratado pela diretoria exclusivamente para resolver problemas pontuais. Neste caso ele, mesmo levantando opiniões e coletando dados diretamente dos trabalhadores da área operacional através de entrevistas ou questionários, dirige todo o estudo sobre os próprios objetivos e fins. Isso, como foi confirmado na análise dos resultados do estágio, causa que o interesse sobre este projetos permaneçam até que 0 pesquisador esteja trabalhando; com a saída do pesquisador todo o processo estudado pára. Se existem outros processos de melhoria a ser estudados, os trabalhadores esperam a chegada de um novo profissional. Não existindo planos de melhoria ergonômica na organização, as pessoas não se sentem diretamente atores ativos que possam interferir e possibilitar as mudanças.

Esta experiência motivou o pesquisador a continuar os estudos ergonômicos com o objetivo de conseguir encontrar soluções mais eficazes para conseguir disseminar a temática da ergonomia e permitir que esta preocupação seja sustentada ao longo do tempo. Além disso, faltando na organização uma pessoa de referência que possa resolver assuntos ergonômicos, cresceu a idéia que os mesmos trabalhadores poderiam ser os protagonistas na preservação da sua saúde, entregando à empresa sugestões de melhoria. Antes de começar a pesquisa, a QUESTÃO DE PESQUISA foi então a seguinte:

Agindo:

- no grau de envolvimento/participação/emancipação dos trabalhadores

- no nível onde se situa a discussão ergonômica na organização

é possível obter resultados ergonômicos mais amplos e duradouros no tempo?

Baseado em tais considerações, e buscando entre as possibilidades de pesquisa existentes na época, o presente estudo foi possibilitado da participação ativa numa fase de um projeto plurianual de ergonomia desenvolvido no Hospital Universitário da Universidade de São Paulo (HU-USP) por professores e estudantes do Departamento de Engenharia de Produção da Escola Politécnica da USP. 
Com o próximo sub-capítulo, serão introduzidos os passos principais de tal projeto plurianual e aonde o autor atuou.

\section{3 - Contextualização do projeto de pesquisa em ergonomia desenvolvido no HU-USP}

O HU-USP desde a sua inauguração foi sede de muitos trabalhos de pesquisa desenvolvidos por várias faculdades da universidade. Focalizados na temática da saúde dos trabalhadores existem muitos trabalhos os quais foram escritos principalmente por estudantes e docentes da Escola da Enfermagem e do Departamento de Fisioterapia, Fonoaudiologia e Terapia Ocupacional da Faculdade de Medicina da USP (BALSAMO e BARRIENTOS, ROSSI, 2000; BALSAMO, 2002; FUGULIN, GAIDZINSKI e KURCGANT, 2003; LANCMAN et al., 2004; COSTA e FELLI, 2005; NUNES et al., 2010).

O enfoque em ergonomia foi introduzido nas pesquisas do HU-USP em paralelo aos muitos trabalhos acadêmicos. O começo de tal projeto foi possibilitado principalmente por interesses convergentes; de pesquisa, por parte de um docente do departamento da Engenharia de Produção da Escola Politécnica da USP (e orientador da dissertação); e de apoio a projetos de melhorias, por parte da Superintendência do HU-USP. O hospital em particular, no começo das intervenções ergonômicas apresentava grandes problemas sobre a saúde dos próprios trabalhadores com altos índices de afastamento e de pessoas com restrições ao trabalho (os quais serão apresentados posteriormente no capítulo dos resultados).

Com o intuito de ajudar em melhorar bem-estar e produtividade, a partir de 2000, foi proposto para o docente da Escola Politécnica e sucessivamente aprovado pela diretoria do HU-USP a introdução de ações ergonômicas locais envolvendo alunos do departamento da Engenharia de Produção da USP. Desde então foram feitas intervenções ergonômicas em diferentes departamentos por estudantes seja de graduação ou de pós-graduação.

Os primeiros trabalhos, de tipo acadêmico (WU, 2002; BENITO, 2004), foram de aplicação da metodologia AET e focalizados no departamento de higienização especializada do HU-USP, área caracterizada por funcionários com uma idade 
média maior daquela de outros departamentos, uma alta carga de trabalho físico, e com impactos psicológicos pelo próprio trabalho ser pouco valorizado.

Em 2006, depois de uma análise específica sobre a tendência do numero de afastamentos nos anos antecedentes em todos os departamentos do hospital, levou também o autor a entender o porquê do alto número de pessoas afastadas do trabalho no Serviço de Arquivo Médico Estatístico (SAME). Partindo disso uma pesquisa de AET mostrou como processos, ambiente e ferramentas não tão eficientes e ótimos levavam as pessoas a contrair doenças ocupacionais, sobretudo devidos a esforços repetitivos (BOLIS, 2007). Foi este trabalho que teve grande influencia para que se originasse a presente dissertação de mestrado, como discutido antecedentemente.

Um grande impulso na parceria entre o Departamento de Engenharia de Produção (apoiado pela Fundação Vanzolini) e o HU-USP começou a partir do final de 2006 com o "Programa de Cooperação Técnica (PCT)". Este trabalho envolveu vários pesquisadores por um total de quatro ações integradas: executar estudos de AET em alguns departamentos, realizar ações de psicodinâmica do trabalho, introduzir um programa de capacitação técnica e enfim, um comitê de melhorias (SZNELWAR et al., 2007).

Esta ultima parceria teve início partindo de uma demanda específica presente no HU-USP. Em 2003, depois do decreto do presidente Lula, que causou a volta ao trabalho de muitos funcionários afastados por vários anos, o superintendente nomeou uma assessora para ajudar na busca de soluções para esta problemática. Em toda a Universidade inúmeros funcionários retornaram ao trabalho com a carta do INSS, sem que os gestores soubessem como proceder pois estas pessoas estavam já desadaptadas. Foram então introduzidas algumas reuniões para discutir o assunto. O grupo que se formou foi chamado de "Grupo LER-DORT", composto por pessoas do hospital e da universidade (como o SESMT e o Departamento de Recursos Humanos - DRH). O primeiro passo prático foi buscar a quantidade de funcionários da universidade que estava voltando do INSS solicitando ao DRH uma lista de todas as pessoas afastadas. Deparando-se com uma quantidade significativa, foi clara a falta de meios para atender as necessidades de toda a universidade, sendo portanto decidido focar a atenção sobre os afastados do $\mathrm{HU}$. Neste período foi criado o serviço de reabilitação contratando mais fisioterapeutas e 
terapeutas ocupacionais. Aos poucos foram chamadas as pessoas que estavam afastadas para que fizessem uma avaliação e uma consulta de fisioterapia, de modo a entender o estado real da saúde de tais trabalhadores e avaliar a sua reinserção no hospital. Tal trabalho gerou bons resultados e grande quantidade de dados além da sensibilização dos profissionais para esta problemática. Um segundo passo consistiu na análise de cada setor do hospital em busca dos principais problemas. Descobriu-se que havia muitos funcionários trabalhando com dor, e que mesmo não estando afastados a longo prazo pelo INSS, freqüentemente se afastavam por pequenos períodos. Foi nesta fase que se intuiu a necessidade de agir e melhorar os processos de trabalho. A fase sucessiva, foi então conversar com os componentes do grupo LER-DORT em busca de solução. Isso levou a muita discussão sobre a necessidade de revisão dos processos de trabalho em cada setor do hospital com a sensibilização dos profissionais e compreensão dos problemas. $O$ envolvimento inicial da equipe da Escola Politécnica foi causado pela busca da assessora por apoio ao grupo LER-DORT, enviando o pedido a um professor recomendado pelo superintendente. $O$ convite foi aceito e 0 referido professor passou a participar de algumas reuniões do grupo LER-DORT, porém sem um compromisso formal. Outro docente da Escola Politécnica também iniciou sua participação, assim em poucas reuniões foi formulada uma proposta para introduzir a cooperação técnica entre o Departamento da Engenharia de Produção e o HUUSP. De convidados, a equipe da Escola Politécnica inverteu a sua posição e começou a ter uma atuação ativa formulando uma proposta, logo aceita, para introduzir uma cooperação técnica entre a Escola Politécnica e o HU-USP consistente nas seguintes propostas ergonômicas:

\section{PCT: estudos de AET.}

Os estudos de AET deste ciclo foram aplicados seja por estudantes de graduação como os de pós-graduação e se concentraram em particular no departamento de nutrição (NAKAHARA, 2008; MITSUISHI, 2009; CASSANO, 2010). 


\section{PCT: análises de Psicodinâmica do trabalho.}

A cooperação entre ações de ergonomia e psicodinâmica do trabalho não foi começada a partir do PCT, mas já a partir dos primeiros estudos no hospital havia ligações entre as duas temáticas. Enquanto anteriormente as ações eram introduzidas independentemente por uma dupla de pesquisadores (ALVARINHO e WU, 2002; SZNELWAR et al., 2004), um chegando da Engenharia da Produção da Escola Politécnica, e outro do Departamento de Fisioterapia, Fonoaudiologia e Terapia Ocupacional da Faculdade de Medicina da USP, mesmo com uma pequena colaboração (aonde por cada trabalho de AET, em paralelo era executado um trabalho de psicodinâmica do trabalho); partindo deste período os dois trabalhos foram desenvolvidos formalmente em conjunto e em cooperação. Com o PTC, pela primeira vez no hospital, a análise psicodinâmica foi conduzida também por um docente e por uma estudante de mestrado da Engenharia de Produção.

\section{PCT: "Grupo de Treinamento e Capacitação".}

O Programa de capacitação técnica (GTC) eve o objetivo principal de criar uma equipe que possa num segundo instante multiplicar e difundir na instituição conceitos de ergonomia, de análise do trabalho e dos riscos, assim que seja possível em visão futura prevenir o aparecimento de doenças ocupacionais. Como definido no relatório inicial do projeto:

\footnotetext{
Através dele, buscamos capacitar um grupo de profissionais a analisar do ponto de vista do trabalho e da produção, as situações de trabalho com a finalidade de diagnosticar e propor melhorias visando adequar o trabalho às características humanas, reduzir e controlar os riscos (SZNELWAR e NEIVA, 2008, p.13).
}

O GTC consistente em um curso oferecido de um professor da Escola Politécnica da USP com a exposição de conceitos de ergonomia e da metodologia AET, o acompanhamento e supervisão de aplicações práticas desenvolvidas em alguns locais da instituição anteriormente escolhidos, e enfim a avaliação das soluções propostas e o acompanhamento dos resultados. 


\section{PCT: Comitê de Melhorias.}

O Comitê de Melhorias (CM) é um meio organizativo que foi criado com a finalidade de conseguir atrelar todas as ações de tipo ergonômico num nível organizacional mais estratégico.

Como definido partindo de um relatório inicial do projeto (SZNELWAR et al., 2007), o objetivo principal da criação deste $\mathrm{CM}$ foi, em primeiro lugar, a definição de políticas de melhorias de condições de trabalho para poder, num segundo estágio, efetivar as melhorias nas condições atuais e na definição de novos projetos.

O CM foi formado em linha permanente da equipe da Escola Politécnica (consistente no docente responsável do projeto, dois mestrandos e uma estudante de iniciação científica), da assessora da Superintendência responsável do projeto pelo hospital, a chefe da enfermagem e a chefe da fisioterapia. Outras figuras profissionais do hospital se agregavam ao grupo dependendo do assunto tratado.

Do lado dos conceitos tratados, desde as primeiras reuniões no 2007 foram definidos quatro eixos de ação principais: vigilância epidemiológica; políticas para trabalhadores com restrições e necessidades especiais; aquisição de materiais, equipamentos, sistemas de informação e serviços; e adequação das instalações.

A volta do pesquisador neste projeto plurianual aconteceu no começo de 2009 através da atuação ativa no $\mathrm{CM}$. $\mathrm{O}$ aporte maior foi dado apoiando e ajudando na implementação de políticas que incluem critérios ergonômicos na aquisição de materiais, equipamentos, sistemas de informação e serviços. Embora a participação tenha ocorrido em tal eixo do $\mathrm{CM}$, na presente dissertação não serão discutidas as aplicações práticas e os resultados alcançados em tal comitê pelo autor.

Partindo também de elementos de atuação na pesquisa, o presente trabalho escrito verterá principalmente na fase de reflexão sobre as ações desenvolvidas no projeto plurianual (em particular CM e GTC) pondo grande atenção no rolo dos trabalhadores e da organização em projetos de melhoria, ou seja, mais detalhadamente, sobre a temática da emancipação e a necessidade de levantar a discussão da ergonomia num nível de decisão mais elevado na organização. 


\section{4 - Estrutura da dissertação}

A seguir apresenta-se a estrutura dos sete capítulos que compõem esta dissertação.

O capitulo 1 situa a presente pesquisa no contexto em que foi desenvolvida a pesquisa ação, apresenta o problema de pesquisa e introduz a questão de pesquisa. Uma segunda parte mostra o conjunto de ações que foram desenvolvidas no Hospital Universitário da USP antes da entrada do pesquisador no projeto.

O capitulo 2 traz o referencial teórico pertinente ao estudo desenvolvido, abordando conceitos sobre ergonomia, emancipação do trabalhador e participação do trabalhador nas teorias organizacionais.

O capitulo 3 apresenta os objetivos, as proposições que nortearam o estudo e a relevância do trabalho.

O capitulo 4 apresenta a metodologia, a fundamentação conceitual da pesquisa, a justificativa da escolha do método e das técnicas para coleta de dados, e as fases percorridas no desenvolvimento do trabalho.

O capitulo 5 apresenta os resultados obtidos em algumas fases da pesquisa ação desenvolvida no Hospital Universitário da USP. Depois da apresentação geral da empresa e da demanda inicial foram introduzidos os resultados de entrevistas desenvolvidas em todo o hospital e algumas experiências do pesquisador.

O capitulo 6 apresenta a discussão dos resultados, a analise e reflexão sobre os objetivos de pesquisa levantados no capitulo 3.

O capitulo 7 traz as conclusões deste trabalho, as limitações de pesquisa e perspectivas para trabalhos futuros. 


\section{2 - REVISAO DA LITERATURA}

A presente pesquisa, partindo dos propósitos estabelecidos na introdução, discute sobre as temáticas da ergonomia, da emancipação do trabalhador, e da sua participação na organização do trabalho.

O tema da ergonomia é apresentado logo no início através de uma introdução geral, para depois focalizarmos na abordagem metodológica AET (Análise Ergonômica do Trabalho) utilizada em vários estágios do projeto plurianual no HU-USP e na vertente da macroergonomia. Partindo desta última, foi introduzida também a ergonomia participativa, o ramo da ergonomia mais ligado ao tema da participação. Esta temática enfim é concluída mostrando a forte ligação entre produtividade e ergonomia, e sobre o Comitê de Ergonomia, ambos presentes na literatura.

O conceito da emancipação encontra-se em posição central neste capítulo. Introduzido com a definição de um dicionário, o argumento foi direcionado na discussão da ligação entre a temática da emancipação e o trabalho, antes como resposta à alienação ao trabalho (incluindo a visão da disciplina de psicodinâmica do trabalho) e depois como meio de ganhar autonomia no alcance dos objetivos empresariais.

Sendo a emancipação do trabalhador uma temática pouco explorada, pelo menos no enfoque requerido pelo mestrando, na última parte do seguinte capitulo é apresentada a base teórica da temática da participação relacionada à temática da organização do trabalho, com a sua evolução no tempo. Particular atenção foi dada ao conceito da ação organizativa e às contribuições do pesquisador Bruno Maggi a esta temática.

\section{1 - Ergonomia}

Mesmo com relatos de cuidado nas condições de trabalho documentados desde os tempos egípcios, e do surgimento do termo "ergonomia" em 1857 no livro do polaco Wojciech Jastrzebowki, a ergonomia moderna nasceu em junho de 1949 com a 
criação da primeira "Sociedade de Ergonomia" fundada por um grupo de pesquisadores ingleses (ABRAHÃO et al., 2009).

O termo "Ergonomia" é composto por duas palavras gregas; ergon (trabalho) e nomos (normas, regras, leis) e denomina o estudo da adaptação do trabalho às características dos indivíduos, de modo a lhes proporcionar um máximo de conforto, segurança, e bom desempenho nas suas atividades no trabalho (FALZON, 2007).

A Associação Internacional de Ergonomia (IEA) em 2000 adotou a seguinte definição:

A ergonomia é a disciplina científica que visa a compreensão fundamental das interações entre os seres humanos e os outros componentes de um sistema, e a profissão que aplica princípios teóricos, dados e métodos com o objetivo de otimizar o bem-estar das pessoas e o desempenho global dos sistemas (FALZON, 2007, p.5).

Centrada na temática do trabalho (ABRAHÃO et al., 2009), a ergonomia é reconhecida como uma disciplina autônoma, mas que precisa se nutrir das aquisições de outras disciplinas em um espírito interdisciplinar (WISNER 2004). Segundo Falzon: "A ergonomia é uma disciplina jovem, sua história é recente. Enraíza-se, portanto, necessariamente em disciplinas mais antigas. Além disso, está em evolução... (LEPLAT e MONTMOLLIN, 2007, p.33)".

O objetivo de tal disciplina é aquele de "transformar o trabalho de forma a adaptá-lo às características e variabilidades do homem e do processo produtivo" (ABRAHÃO et al., 2009, p. 19).

Na fase de análise ergonômica, como descrito por Falzon (2007) e Daniellou (2004), é necessário alcançar resultados positivos em duas principais esferas, certas vezes em tensão entre si: uma centrada na organização e no seu desempenho (em termos de produtividade, eficiência, confiabilidade, qualidade, etc.), e outra centrada nas pessoas (em termos de segurança, saúde, conforto, facilidade de uso, bem estar, etc.). Na aplicação prática dentro das organizações precisamos, portanto, buscar o melhor trade-off entre as duas esferas, sendo que a ergonomia, como explicado por lida (1990), não deve situar a produtividade e a eficiência como objetivo principal das próprias análises, pois isso poderia causar sofrimento e mal estar no trabalhador durante a execução de suas atividades, indo contra os princípios da ergonomia. 
A ergonomia nasceu contrapondo-se à visão predominante da época em que pretendia-se adaptar o Homem à sua profissão (BONNARDEL, 1943 apud WISNER, 2004) e foi introduzida na Grã-Bretanha para adaptar a máquina ao homem, e na França para adaptar o trabalho ao homem (DANIELLOU, 2004). Tais diferenças derivadas dos diversos contextos culturais foram as causas do nascimento das duas principais abordagens metodológicas na ergonomia: a Human Factors (HF) e a Análise Ergonômica do Trabalho (AET). A primeira, fundada por K. F., H. Murrel no ano de 1949 em Oxford e Londres, de tradição anglófona, atualmente desenvolvida principalmente nos EUA e na Grã-Bretanha, é uma ergonomia de laboratório, caracterizada pelo encontro de todas aquelas disciplinas que cuidam do trabalho, das ciências biomédicas, higienísticas, politécnicas e tecnológicas, deixando um pouco de lado aquelas sociais (MAGGI, 1993). A segunda, fundada na metade dos anos $50 \mathrm{com}$ Faverage, de tradição francófona e atualmente desenvolvida principalmente na França, Bélgica e Suíça, não é experimental, mas se baseia no estudo de campo aonde acontece o trabalho e na análise detalhada dos casos singulares. Além das disciplinas da metodologia anterior, existe diálogo também com a psicologia do trabalho e a sociologia do trabalho (MAGGI, 1993).

A abordagem seguida pelo autor da presente dissertação de mestrado é a AET, a qual será analisada com maior profundidade no próximo parágrafo.

\subsection{1 - Abordagem: Análise Ergonômica do Trabalho}

Daniellou (2004) a definiu como Método destinado a examinar a complexidade, sem colocar em prova um modelo escolhido a priori.

Ao desenvolvermos uma ação ergonômica buscamos elementos que nos permitam transformar o trabalho e também produzir conhecimentos. Nesta perspectiva a ergonomia foi se desenvolvendo, adotando como referência a noção de variabilidade, a distinção entre tarefa e atividade, e a regulação das ações associada ao reconhecimento da competência dos trabalhadores (ABRAHÃO et al., 2009, p. 19).

Um dos conceitos fundamentais da presente abordagem é a distinção entre o conceito de tarefa e de atividade: "A tarefa é o que se deve fazer, o que é prescrito pela organização. A atividade é o que é feito, o que o sujeito mobiliza para efetuar a 
tarefa" (FALZON, 2007, p.9). Com base em tais conceitos, a tarefa é o trabalho prescrito pela empresa, o qual influencia e constrange as atividades, e assim 0 trabalho real (GUÉRIN et al., 2001).

As empresas definem as tarefas para obter maior controle sobre o trabalho. $\mathrm{Na}$ administração científica do trabalho de Taylor chegava-se até a definição precisa dos gestos a serem executados. Hoje a definição das tarefas evoluiu, não é mais tão rígida, tendo incorporado o conceito de variabilidade para fazer frente aos imprevistos e aleatórios (ABRAHÃO et al., 2009).

Analisar ergonomicamente a atividade significa analisar as estratégias usadas pelo operador para administrar a distância entre "o que é pedido" e "o que a coisa pede" (GUÉRIN et al., 2001).

Para estudar as conseqüências das atividades sobre a saúde do trabalhador não é possível observar simplesmente os fatores de risco, mas sim ter conhecimento do papel ativo do trabalhador, de modo a poder formular os modelos operatórios mais favoráveis para a saúde do mesmo (GUÉRIN et al., 2001).

É essencial que nas intervenções haja colaboração entre os trabalhadores e quem analisa as situações de trabalho. Este último, através da análise do trabalho real, pode identificar as estratégias operativas que os trabalhadores utilizam em resposta às dificuldades, para conseguir assim alcançar os próprios objetivos (do trabalho, mas também pessoais). É este conhecimento que permite tomar as atitudes mais eficazes para melhorar, ou pelo menos amenizar, as condições de trabalho (DANIELLOU, 2005).

Outro importante ponto da abordagem da AET é que esta é centrada na análise das atividades dos operadores em situações reais de trabalho, através de estudos de campo e observações sistemáticas das situações reais do trabalho (ABRAHÃO et al., 2009).

A AET é uma metodologia tipicamente utilizada pelo ergonomista na análise de uma ou mais atividades com o fim de investigar o trabalho e propor melhorias de acordo com os princípios da ergonomia.

A aplicação de tal metodologia é justificada partindo de uma demanda de análise que pode ser de diferentes naturezas: ou partindo de questões não resolvidas em que existem riscos nas situações de trabalho que não podem ser mais ignorados 
(ação corretiva), ou partindo de uma análise proativa como, por exemplo, um processo de projeto que permita antecipar o surgimento de problemas de saúde e incorporar o conhecimento dos trabalhadores. (DUARTE, 2001). Para tais fins a demanda pode originar-se de múltiplos aspectos, provindo de quatro lugares principais: da direção da empresa, dos departamentos técnicos, dos departamentos do pessoal ou dos trabalhadores e seus representantes (GUÉRIN et al., 2001).

Embora seja apresentada por diferentes autores com pequenas variações, Guérin et al. (2001) propõe o próprio esquema geral da abordagem prática que apresenta de modo exemplificado os principais passos que tal metodologia propõe.

Este pode ser definido como um modelo metodológico de intervenção e transformação que permite levantar a complexidade presente nas relações entre trabalho e homem, sem se basear em estudos através de modelos a priori (WISNER, 2004).

Como apresentado na ilustração 1, os principais momentos são cinco.

O primeiro é de análise da demanda, buscando compreender a sua origem (se real ou formal), os problemas (dividindo-os entre os aparentes e os fundamentais), analisar os diferentes pontos de vista dos atores, as expectativas, e os meios disponíveis que acompanharão a AET. O objetivo desta fase é delimitar a situação de estudo, para entender as necessidades reais que serão analisadas durante o estudo e eventualmente contratar um maior engajamento da diretoria no desenvolvimento do projeto.

A fase sucessiva é de análise do funcionamento da empresa (ou organização) e as características da sua população. Com estes dados é possível contextualizar a situação organizacional e humana, permitindo que o pesquisador possa conhecer alguns aspectos macro da empresa. Fundamental nesta fase é conhecer a dimensão econômica e comercial, a dimensão social e demográfica, as leis e as regulamentações, o ambiente geográfico da empresa, a dimensão técnica, a produção e a sua organização (GUÉRIN et al., 2001). É de fundamental importância saber idade, escolaridade e tempo "de casa" da população em análise e a sua evolução, dados que permitem entender como a força de trabalho da empresa está evoluindo e quais pontos fortes ou mais críticos ela pode apresentar, para posterior valorização. A conclusão desta etapa permite uma maior delimitação das situações a 
serem analisadas e a introdução das hipóteses gerais que irão nortear o estudo ergonômico.

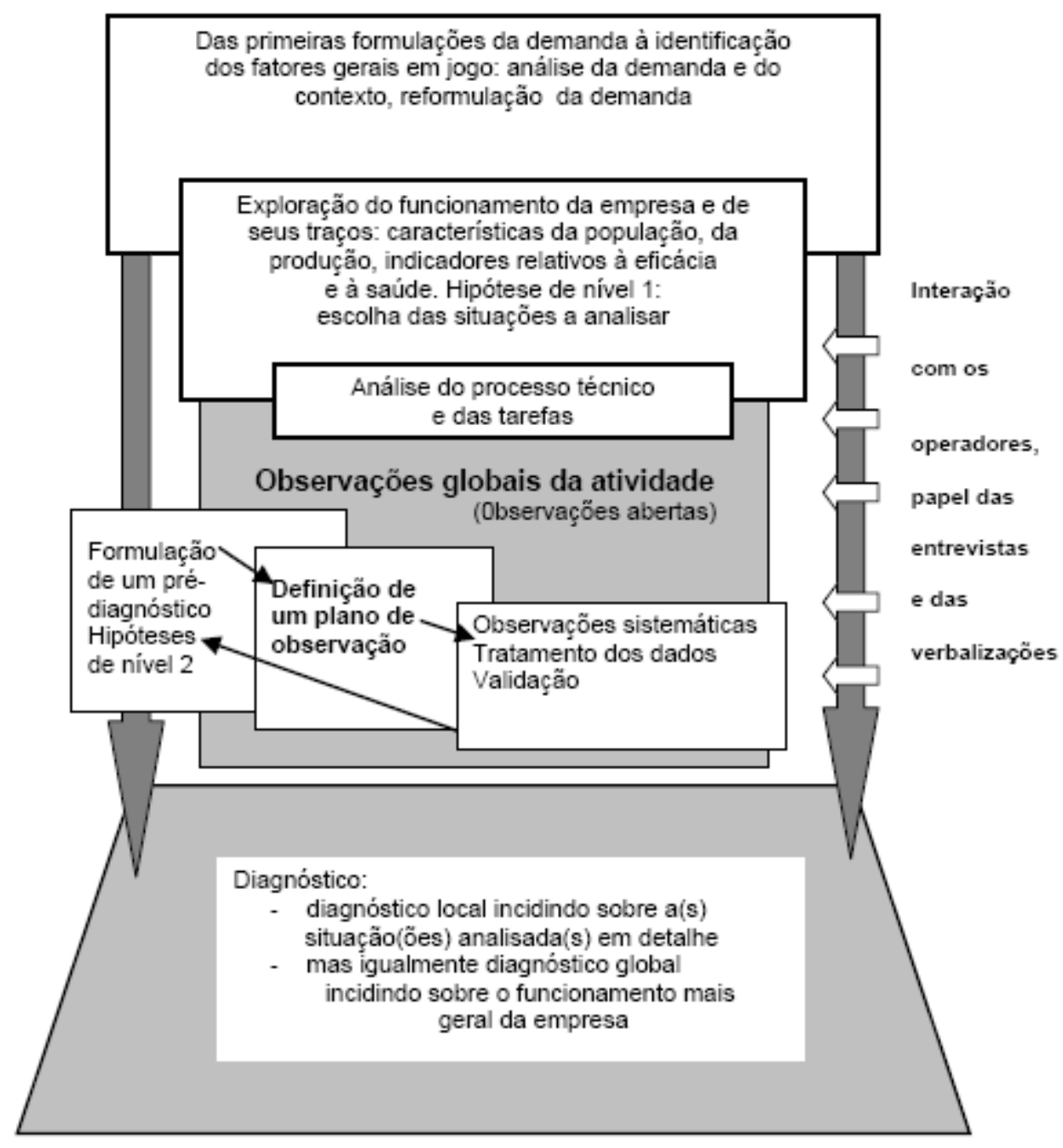

llustração 1 - Esquema geral da abordagem AET.

Fonte: Extraído de Guérin et al. (2001, p. 86)

A terceira fase leva à análise do processo técnico e das tarefas. O objetivo do levantamento de tais dados é colocar em evidência os determinantes e as exigências prescritas pela empresalorganização. Estes contribuem no condicionamento da execução do trabalho, tendo assim impacto formal na situaçãoproblema.

O quarto momento é a análise das atividades, na qual procura-se identificar, ao longo do trabalho, os indicadores críticos que caracterizam a situação-problema em termos de gênese e processos. As observações nesta fase são inicialmente globais sobre todas as atividades das situações escolhidas e são do tipo aberto, para coletar 
dados mais gerais. As observações globais desencadeiam a formulação de um prédiagnóstico e as relativas hipóteses de segundo nível. Para confirmá-las, ou não, estas são investigadas através de planos de observação mais estruturados e orientados. Uma vez levantados os dados, estes são tratados e validados para assegurar a confiabilidade. Enquanto as observações gerais são realizadas continuamente nesta fase, a formulação do pré-diagnóstico e das observações sistemáticas é feita em ciclos. Algumas hipóteses podem não ser confirmadas, assim como novos dados estruturados podem levar a novas hipóteses.

A última fase é a elaboração do diagnóstico, com a perspectiva de descrever a situação-problema, situando e explicando as causas de eventuais indicadores críticos e elaborando em seguida um conjunto de recomendações e propostas. Busca-se transformar as condições de trabalho existentes com a finalidade de aumentar o bem-estar para os trabalhadores e melhorar a qualidade, eficácia, e produtividade dos output da empresa/ instituição.

As três fases centrais, sobretudo na análise das atividades, necessitam da interação com os operadores para permitir que o pesquisador possa levantar os dados, mas também para que estes possam descrever a realidade das próprias atividades e modalidades operatórias, que na maioria das vezes diferem do prescrito. A prática ergonômica, como escrito por Falzon (2007) pode ser enxergada como uma atividade de resolução participativa.

Esta abordagem metodológica envolve principalmente a análise dos processos, da organização do trabalho, do comportamento do ser humano lá inserido, e do posto de trabalho, com os seus equipamentos, ferramentas, lay-out e variáveis ambientais.

\subsection{2 - Evolução da ergonomia}

Silva-Bau (2002) identificou quatro fases: a fase da Ergonomia Hardware ou do Posto de trabalho, com preocupação sobre questões fisiológicas e biomecânicas, a fase da Ergonomia do Meio Ambiente, com ênfase em encontrar a melhor relação entre o homem e os aspectos ambientais (ruído, iluminação, temperatura, etc., além das questões ecológicas) e a fase da Ergonomia de Software ou Cognitiva aonde a atenção é focalizada também no aspecto psico-cognitivo dos trabalhadores na 
execução de suas tarefas. A última fase é aquela da Ergonomia Organizacional, aonde o campo de estudo é ampliado e são analisados e otimizados todos os aspectos organizacionais que têm influência sobre o trabalho.

A ergonomia organizacional está passando por um forte desenvolvimento e, segundo Guimarães (1999) é conhecida internacionalmente como ODAM (Organizational Design and Management), e para alguns representando um sinônimo de macroergonomia.

\subsection{3 - Macroergonomia}

Um dos principais problemas nas intervenções ergonômicas tradicionais é que, permanecendo com a mesma estrutura organizacional, os resultados das ações de melhoria ergonômica mantêm-se parciais e limitados durante o período de intervenção: "É necessário melhorar os aspectos físicos no trabalho, mas isso não é suficiente para que a ergonomia possa melhorar as condições humanas" (IMADA e CARAYON, 2008, p.415).

É a partir desta necessidade que na década de 1980 o campo de estudo da ergonomia foi ampliado, abrindo a introdução do termo de Macroergonomia. A análise ergonômica além de ser desenvolvida no nível (micro) da situação ou do posto de trabalho, ou do homem individualmente, é ampliada partindo da idéia da organização como um todo, aonde mudanças em aspectos organizacionais, sobretudo de tipo estratégico, desencadeiam um forte impacto também nas situações mais locais. Com as palavras de Imada e Carayon, (2008), é necessário que seja considerado o contexto dessa mudança e as forças que facilitam e inibem melhorias ergonômicas.

A macroergonomia é definida por Hendrick (2005), um dos primeiros ergonomistas a se preocupar em defini-la, como uma abordagem sócio-técnica de cima para baixo (top-down) para a concepção do trabalho no sistema, e o seu transporte ao posto de trabalho e as interfaces relacionadas entre humanos e máquinas, assim como os seres humanos e softwares. O objetivo final da macroergonomia é garantir que os sistemas de trabalho sejam totalmente harmonizados e compatíveis com suas características sócio-técnicas. 
O ponto de vista deste autor baseia-se na teoria dos sistemas. Ele afirma que o principal objetivo é harmonizar as partes do sistema entre si e com o meio ambiente.

Ainda segundo Haro e Kleiner (2008) a macroergonomia representa a formalização da atenção sobre o 'design' da organização e dos fatores de gerenciamento em ergonomia. Também Brown Jr. (1990) explica que a macroergonomia entende as organizações como sistemas sócio-técnicos e incorpora conceitos e procedimentos da teoria dos sistemas sócio-técnicos no campo da ergonomia.

Esta ampliação do campo de análise, segundo Imada (1991) deurse como seqüência à internacionalização da economia com a globalização, à passagem gradual para uma economia mais concentrada nos serviços, à introdução de novas tecnologias, à necessidade de que as empresas fossem mais reativas ao mercado, à mudança do perfil da mão de obra, induzindo as organizações a se converterem em estruturas mais ágeis e por isso com organogramas mais achatados, orientadas para o funcionamento em rede e essencialmente mais participativas. Foi este mesmo ambiente, para Brown Jr (1995), que impulsionou a introdução de conceitos e princípios ergonômicos diferentes do passado, aonde não são mais feitas intervenções pontuais e locais, mas políticas estratégicas a nível organizacional, propiciando a introdução de programas ergonômicos transversais em toda a organização e incorporando esta temática como um valor e uma crença na organização.

lida (1990) define a macroergonomia como o desenvolvimento e aplicação da tecnologia da interface homem-máquina em toda a organização.

Ao longo dos estudos e pesquisas desenvolvidas pelos autores principais, houve uma mudança em relação ao foco da análise macroergonômica, principalmente na direção categórica. O enfoque passou de exclusivamente descendente (top-down) para abranger também o sentido ascendente (bottom-up), de forma ampliar a visualização, verificação, e possibilidade de projetos. Hoje encontramos o que podemos denominar como "estado médio", que possibilita a observação geral dos diagnósticos e a consolidação da formulação do caderno de encargos (recomendações ergonômicas a nível organizacional) visando a adaptação do ambiente organizacional ao homem como um processo, sem deixar de lado a produtividade, a qualidade e a saúde do trabalhador (HENDRICK e KLEINER, 2001; GUIMARÃES, 2002). 
Com a macroergonomia, a ergonomia tornourse uma ferramenta de gestão empresarial. Gestões baseadas em definição de tarefas, de processos e de produtos com as suas certificações nada adiantam sem a consideração dos hábitos, dos aspectos culturais, dos sentimentos, e enfim do lado humano. A ergonomia então tenta juntar os aspectos técnicos e social, para chegar a um ótimo global.

Isso não seria possível sem uma visão antropocêntrica. Levar a atenção ao homem significa assim mudar conceitos de gestão na organização, levando em consideração sobretudo a qualidade de vida no trabalho e assim a participação do trabalhador. É assim que este último pode reapropriar-se do "saber fazer" e trazer à organização os seus conhecimentos e a própria criatividade (DUTRA, 2003).

Sobre a macroergonomia existe uma crítica feita por Daniellou (2004) constatando que quando unimos uma parte da organização do trabalho, aquela ligada à sóciotécnica, à ergonomia, pode haver o risco que esta ampliação do número de disciplinas atrapalhe o ergonomista. Este poderia ser ultrapassado pela quantidade de conhecimentos, com o risco de poder entregar indicações muito vagas.

Embora esta crítica, a macroergonomia possibilita que as empresas enxerguem a ergonomia com uma visão menos limitada. Como descrito por Dul e Neumann (2009), atualmente os gerentes costumam associar a ergonomia com a saúde, segurança ocupacional, e a legislação correlata (como custos); assim eles não são motivados a aplicar a ergonomia. Diferente seria se estes gestores conseguissem permitir que a ergonomia pudesse contribuir com as estratégias da empresa e os objetivos de negócio. Aplicada em tal nível estratégico, Dul e Neumann, mostraram grandes benefícios.

Também segundo lida (1990), a aplicação e o aprimoramento da tecnologia da interface homem-máquina, típica da macroergonomia, pode levar à melhoria da qualidade, das condições de trabalho e da eficiência através da redução da fadiga e do trabalho repetitivo na organização do trabalho e do aumento da participação dos trabalhadores nas decisões do dia-dia, envolvendo-os no próprio trabalho.

A aplicação da ergonomia envolve custos, mas se os projetos ergonômicos são bem planejados, estes podem trazer benefícios maiores em termos de custos poupados (HENDRICK, 2003). Embora isso seja possível para qualquer intervenção ergonômica, Hendrick (1991) mediu que uma análise macroergonomica com forte 
suporte da diretoria e dos trabalhadores pode proporcionar melhorias da ordem de 50 a $90 \%$, enquanto que na abordagem micro as melhorias são de apenas 10 a $25 \%$.

Em outro artigo, Hendrick (2008), discutindo sobre os benefícios de projetos ergonômicos, em particular de tipo macroergonômico, explicou como:

- Projetos bem estruturados de ergonomia podem trazer benefícios nos custos diretos de 2 até 10 vezes o quanto pago por toda a intervenção ergonômica, e um retorno dos investimentos entre 6 e 24 meses.

- Os programas eficazes de ergonomia em grandes projetos de desenvolvimento de sistema constituem apenas $1 \%$ do orçamento do projeto de engenharia.

- Melhorias ergonômicas com o objetivo de diminuir os acidentes e os distúrbios osteomusculares, normalmente melhoram também a produtividade.

- Intervenções de tipo macroergonomico tipicamente alcançam melhorias de 50 a $90 \%$ em um ou mais critérios de eficácia do sistema de trabalho

\subsection{4 - Ergonomia participativa}

A ergonomia participativa é um dos métodos para a implantação do enfoque macroergonomico da ergonomia, considerado também como uma "filosofia distintiva sobre as últimas décadas" (HAINES et al., 2002). Permanecendo na macroergonomia, ao invés de desenvolver processos descendentes nos quais 0 ergonomista estuda a organização e as situações, chegando no diagnóstico e na recomendação de soluções a serem implementadas, esta perspectiva proporciona o envolvimento dos trabalhadores para que eles sejam co-produtores das soluções (HENDRICK e KLEINER, 2001).

Segundo Hendrick (2009) a ergonomia participativa é uma metodologia comprovada para garantir que os benefícios derivados de uma intervenção macroergonômicas durem. O conceito base é entregar técnicas acessíveis para proporcionar estudos macroergonomicos nas organizações, deixando a possibilidade que os próprios trabalhadores possam participar de todas as fases da intervenção ergonômica. A idéia é transformar os trabalhadores em agentes de melhoria das condições de 
trabalho, envolvendo-os nas análises e nas fases de desenvolvimento e implementação de processos de melhoria.

Este método se baseia no conceito que ninguém, se não o próprio trabalhador, conhece melhor as situações do próprio posto de trabalho. É o trabalhador o sujeito que pode obter uma maior aproximação e compreensão do próprio trabalho (ZALK, 2001). O envolvimento do trabalhador em resolver problemas ergonômicos pode ajudar em aumentar a experiência, a confiança, e enfim o seu interesse, permitindo dispensar a presença de um especialista nas análises. Envolver os trabalhadores permite domínio e compromisso sobre as soluções propostas, minimizando a possibilidade que as soluções encontradas sejam rejeitadas. Outra vantagem considerável da participação dos trabalhadores é que o seu envolvimento permite conscientizá-los em assuntos ergonômicos e sobre o aidado da própria saúde, permitindo então introduzir e manter uma cultura permanente do bem-estar na organização (HENDRICK, 2008).

Esta vertente da macroergonomia não é tão imediata e precisa de um grande cuidado na fase de planejamento e introdução nas organizações. Kuorinka (2001) descreve projetos de ergonomia participativa realizados, mas que levaram a várias dificuldades devido à incompreensão e discordância. Precisaria-se avaliar e ter a percepção sobre os conhecimentos e as atitudes dos participantes no início do projeto, adequando assim o processo de participação e as suas atividades.

\subsection{5 - A produtividade e os problemas levantados pela temática da ergonomia}

De acordo com Haak (2000), as pessoas querem se envolver no trabalho, mas para isso precisam ser motivadas e ter a liberdade de agir entendendo que podem produzir resultados positivos através das próprias atividades de trabalho. Isso contrasta com a necessidade das empresas em diminuir a variabilidade dos resultados dos próprios trabalhadores, e das mesmas desejarem serem as únicas a poder organizar o trabalho.

Observando o ambiente de trabalho no último período pode-se constatar como a importância da tecnologia de informação se expandiu, resultando na construção de 
lugares de trabalho sempre mais ligados à conectividade tecnológica e em videoterminais.

Também no ambiente das instituições dos países mais desenvolvidos economicamente existe uma preocupação sempre maior em dirigir as empresas a produzir com ótimas políticas de segurança e saúde, já considerando que estas proporcionariam um ganho sobre as despesas sociais e sobre a produtividade da empresa (SCHMITTER, 2003; EUROPEAN AGENCY FOR SAFETY AND HEALTH AT WORK, 2004).

O resultado deste período histórico faz com que as empresas estejam encontrando problemas sempre mais recorrentes: psíquicos, como estresse (FALZON e SAUVAGNAC, 2007); doenças biomecânicas, como movimentação de cargas e doenças DORT, e em geral baixas motivação na própria organização.

Por conseqüência destes problemas as empresas estão enfrentando um aumento na incidência de turn-over, afastamento por problemas de saúde, ausências ligadas ao desconforto, um aumento nas paradas da produção, altas taxas de sucata, crescentes custos de compensação, e baixo comprometimento dos trabalhadores.

Estas temáticas são normalmente estudadas pela matéria da ergonomia. Introduzir conceitos ergonômicos na empresa permite aumentar o conhecimento e motiva os trabalhadores a terem um comportamento mais engajado. Os resultados são melhoramento no bem-estar dos trabalhadores e sua conseqüente motivação com o efeito direto de melhoramento na prestação e na produtividade do trabalho (ROBERTSON et al., 2002).

A forte relação entre ergonomia e produtividade pode levar a ganhos apenas através da sinergia entre os dois, como apresentado na ilustração 2 (NEUMANN e WINKEL, 2005).

De acordo com Generalis e Mylonakis (2007) os fatores ergonômicos que afetam a produtividade total são: o projeto do lugar de trabalho, os fatores ambientais, a produtividade homem- máquina, o projeto dos equipamentos e das ferramentas e fatores organizacionais. De acordo com isso, muitos outros estudos mostraram os efeitos positivos ao aplicar princípios econômicos em tais áreas (ZANOTTI, 1997; DAS; SHIKDAR, 1999; RESNICK; DERANGO et al., 2003; BRADBURY, 2009). 


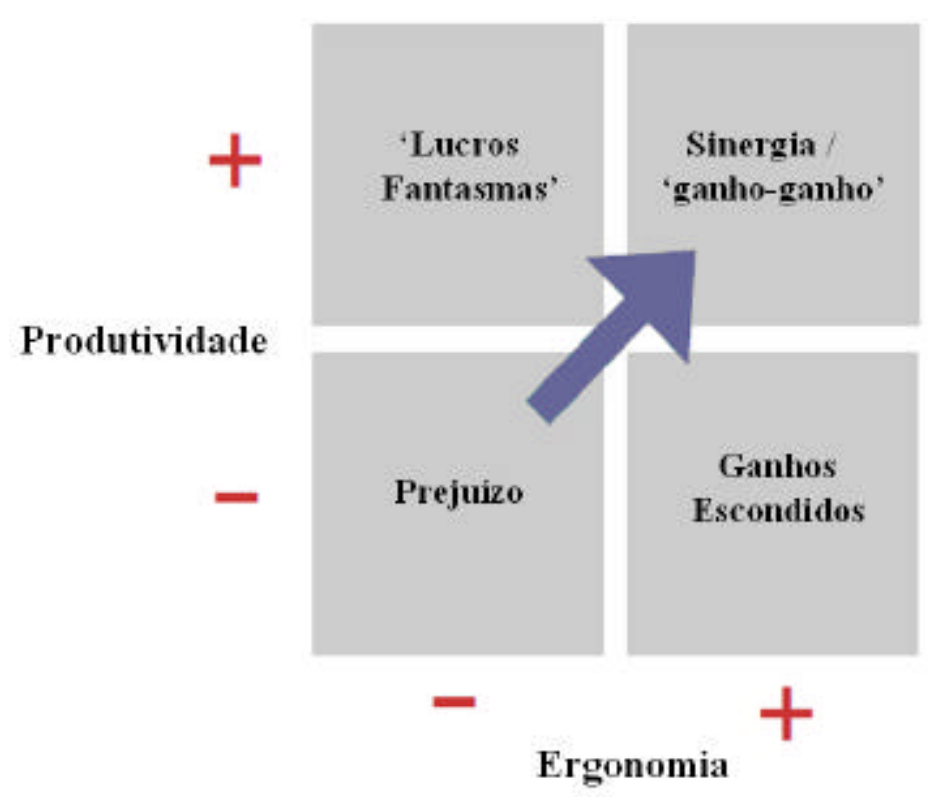

llustração 2 - Modelo de duas dimensões produtividade-ergonomia.

Fonte: Adaptado de Neumann e Winkel (2005).

\subsection{6 - Comitê multifuncional e de ergonomia}

Um dos problemas principais nas intervenções ergonômicas tradicionais é que, permanecendo com a mesma estrutura organizacional, os resultados das ações de melhoria ergonômica mantêm-se parciais e limitados durante o período de intervenção. Torna-se então necessário introduzir um processo constante de monitoramento e de alinhamento das situações de trabalho não conformes com as situações de trabalho de referência. Por isso é tão importante inovar na estrutura organizacional, e uma das possíveis soluções é a implementação de um comitê multifuncional de melhoria (COCKELL e VASCONCELOS, 2002; MARRAS e ALLREAD, 2005)

Comitê multifuncional é definido pela Fundação Nacional da Qualidade (2008) como:

[...] grupos de trabalho, que podem ser permanentes ou temporários, normalmente são formados por pessoas de diversas áreas e que tenham objetivos comuns, tais como a realização de projetos específicos ou a gestão de algum processo que permeie diversas áreas." 
Um grupo multinacional pode ser constituído também com o objetivo de prevenir problemas de tipo ergonômico. Tal meio organizacional vai permitir que a ergonomia seja elevada além da singular situação de trabalho e possa interferir na estrutura organizacional.

A implementação deste tipo de comitê é ligada a uma abordagem macroergonomica e participativa, aonde se propõe um envolvimento direto de todos os para solucionar os problemas sobre a saúde dos trabalhadores, sobretudo os mais importantes e os transversais às áreas de atuação da organização. Segundo Nagamachi (1996), se as pessoas na organização participam da tomada de decisões elas são capazes de experienciar a utilização de suas habilidades de discernimento, alem de fornecer às pessoas um sentimento de responsabilidade e comprometimento com a organização.

É ressaltada a importância de que o comitê consiga envolver os trabalhadores no projeto de mudança, permitindo que estes sejam atores ativos no processo de melhoramento (LOPES e GUIMARÃES, 2001) desde a concepção até a operação.

Os objetivos do comitê de ergonomia são: pesquisar sobre os lugares de trabalho e as problemáticas que estes podem trazer, prevenir que os problemas de saúde apareçam (e caso aconteçam, resolvê-los junto aos trabalhadores), acompanhar todas as fases de um projeto ergonômico e gerar sensibilidade nas temáticas da ergonomia. O objetivo final é conseguir obter uma abordagem proativa introduzindo as soluções antes que o problema apareça (MARRAS e ALLREAD, 2005).

Guimarães (2002) acrescenta que ao comitê de ergonomia , cabe acompanhar todas as fases de um projeto de ação ergonômica na empresa tendo em vista o posto, o ambiente (físico e psicossocial), o conteúdo e a organização do trabalho, enfim, a qualidade de vida como um todo. Este comitê não é necessariamente responsável por atuar, sozinho, em todas as ações ergonômicas definidas como essenciais para a empresa, podendo solicitar auxílio de especialistas externos (sobretudo no caso de uma ação mais aprofundada ou complexa).

Não existe um único formato de comitê de ergonomia (SILVERSTEIN et al., 1991; NAGAMACHI, 1995; MOORE e GARG, 1998, ST-VINCENT, CHICOINE e BEAUGRAND, 1998; HAGG, 2003; TORMA-KRAJEWSKI et al., 2007; VILLENEUVE et al., 2007; ACOSTA e MORALES, 2008; NEUMANN, EKMAN e WINKEL., 2009). 
Guimarães (1999) por exemplo, propõe a utilização do comitê de ergonomia junto à metodologia da Análise Macroergonômica do Trabalho (AMT), dela desenvolvido.

Embora haja algumas diferenças na aplicação, existem características em comum. Os participantes deste tipo de comitê chegam de áreas heterogêneas. Como apresentado na ilustração 3, podem chegar da diretoria, de trabalhadores da área operacional, staff técnico, engenheiros, e dos comitês de saúde e segurança (OHCOW, 2001).

Trabalhadores

Fornecem conhecimentos do trabalho e limitaçỗes dos trabalhadores.

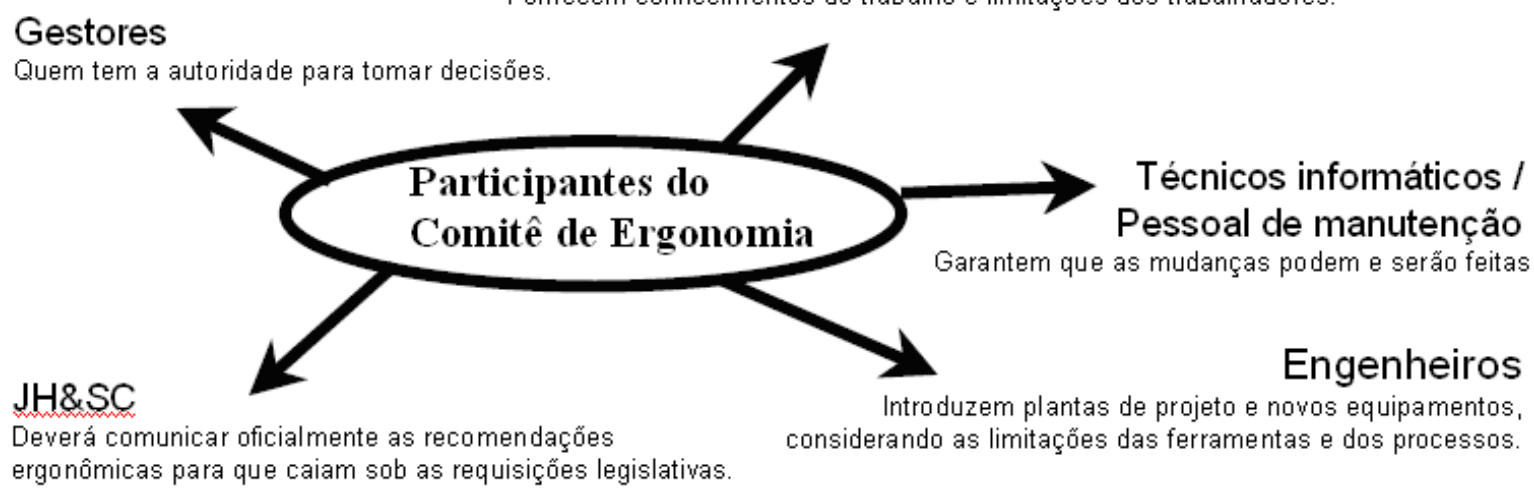

Ilustração 3 - Participantes aconselhados para o Comitê de Ergonomia.

Fonte: Adaptado de OHCOW (2001).

Aspectos importantes na fase de implementação de um comitê de ergonomia são o suporte dos trabalhadores e da diretoria, definir claros objetivos, e estabelecer expectativas realísticas. Além disso é importante que os participantes do comitê sejam treinados em assuntos ergonômicos (OHCOW, 2001).

Em um trabalho de comparação de duas diferentes realidades empresariais nas quais foi implementado um comitê ergonômico são individuados três cuidados: a lentidão em implementar tal inovação, a necessidade de compromisso por parte da empresa para viabilizar recursos econômicos, e querer a participação efetiva de colaboradores da empresa (SOARES et al., 2007). 


\section{2 - Emancipação}

Através de uma busca nos principais dicionários foi encontrada a seguinte definição:

1. Libertação de uma condição de inferioridade, de constrição. SINONIMO: libertação, resgate, e. de um povo da ditadura || e. feminil conquista por parte da mulher de direitos iguais aos dos homens.

2. No direito moderno, o ato que reconhece ao menor que fez dezesseis anos a possibilidade de casar-se e a capacidade de agir dentro dos limites da administração ordinária (SABATINI COLETTI, 2007).

A emancipação, em outras palavras e no sentido mais lato do termo, refere-se a todas as ações que permitem a uma pessoa ou grupo o acesso a um estado de autonomia através da cessação de dependência (de sujeição) por qualquer autoridade ou poder. Este termo pode ser relacionado a várias temáticas e têm variações de significado dependendo do contexto no qual inserido. O termo pode ser ligado a muitos assuntos, entre os quais eventos históricos (emancipação católica em 1829, hebraica em 1791, russa em 1861, a proclamação de emancipação do presidente dos EUA Abraham Lincoln), políticos - emancipação das mulheres ou de direitos da família - emancipação do menor (CATALDI et al., 2009).

Embora a amplitude da temática da emancipação, o que interessa ao autor na presente dissertação de mestrado é a sua interface com a temática do trabalho. Os primeiros eventos (na ordem histórica) de utilização do termo ligados ao trabalho, foram as fases históricas de libertação dos escravos por parte dos patrões, que acompanharam as diferentes civilizações, entre as quais a Egípcia, a Romana e as colônias das Américas (CATALDI et al., 2009). Neste caso o termo 'emancipação' é utilizado para dar sentido à questão da libertação, definindo exclusivamente o fato dos escravos serem liberados da própria condição social e também das condições de trabalho conseqüentes.

O período histórico no qual a emancipação tornou-se uma temática bem definida (e não uma simples palavra definindo um período) foi no século XIX em 
correspondência ao desenvolvimento das atividades econômicas conseqüentes da primeira revolução industrial (1780-1860). Traços distintivos de tal período foram a especialização das tarefas para melhoria do rendimento das atividades e da padronização dos componentes, para permitir que as peças produzidas sejam intercambiáveis (CATALDI et al., 2009). Neste período a temática da emancipação é ligada estreitamente à alienação.

Na filosofia este termo se fez presente já com Rousseau, Fichte e Schelling, mas uma teoria propriamente dita foi introduzida por Georg Wilhelm Friedrich Hengel na "Fenomenologia do espírito", utilizando o termo alienação para indicar o estranhar da consciência de si mesma, pela qual ela se considera como uma coisa, e o estranharse é um processo que vai da consciência à autoconsciência (IMBIMBO, PARASPORO e SALUCCI, 2004).

O termo alienação foi utilizado exclusivamente do ponto de vista filosófico, mas foi Karl Marx quem indagou as causas e quais fenômenos sociais a geravam, conduzindo então uma análise econômica e política nas obras "Manuscritos econômico-filosóficos do 1844", "Lineamentos fundamentais da crítica da economia política (1857-58)" e "O Capital". Segundo ele, na sociedade burguesa o operário se encontra alienado do produto do próprio trabalho, da própria atividade, do gênero humano e dos outros homens. O operário fica infeliz não podendo desenvolver livremente nenhuma atividade física e espiritual, mortificando o próprio corpo e espírito. A força trabalho é um bem que o trabalhador é obrigado a vender para sobreviver, e o trabalho torna-se imposto por uma necessidade acidental exterior, e não por uma necessidade real interior (IMBIMBO, PARASPORO e SALUCCI, 2004). O conceito da alienação surge do fato que Marx entende a noção de pessoa essencialmente como ser social, em contraste com a concepção do mercado liberal, de uma pessoa como ser econômico (LAMBERT e WEBSTER, 2006).

Para superar a alienação no trabalho Marx propõe a emancipação do proletariado. A busca da emancipação é uma temática discutida, por exemplo, em um dos textos presentes nos "Anais Franco-Alemães", ou seja na "Crítica da Filosofia do Direito de Hegel. Introdução" nos quais ele propõe como única via possível para o alcance da emancipação a revolução e o imperativo categórico de derrubar as relações aonde o homem é uma realidade escravizada e abandonada (IMBIMBO, PARASPORO e SALUCCI, 2004). 
Estas teorias foram a base para o fortalecimento de alguns movimentos políticos, sobretudo de esquerda, mas também dos movimentos operários. Baseados em ideais de emancipação, estes últimos ganharam muita força, sobretudo no final do século XIX e no começo do século XX, com uma explosão no número de greves nas fábricas, sobretudo na Europa (CATALDI et al., 2009).

Com tal significado, esta palavra é utilizada ainda hoje pelos sindicatos, sobretudo aqueles mais ligados às correntes políticas de esquerda, para defender os direitos dos trabalhadores. Um caso que possa servir de exemplo se encontra nas disputas entre os sindicados e a FIAT, em Pomigliano - Itália, em junho de 2010 (GIANOLA, 2010). Discutindo sobre tal questão é possível ver como a temática da emancipação é ainda atual: "Para o sindicato, no entanto, além dos ideais e das questões políticas, ainda hoje permanece o compromisso com o trabalho que é, de fato, o principal processo de emancipação humana" (FOCCILLO, 2010).

O tema da emancipação foi muito utilizado politicamente ligando-o á revolução e às "ideologias de esquerda", mas não faltam exemplos com diferentes olhares sobre a temática. Segundo Montgomery (1993), por exemplo, a participação dos trabalhadores na política permitiu a eles a conquista de poder, assim como nos EUA, no começo do século $\mathrm{XX}$, o processo de democracia possibilitou o mercado livre (capitalismo) e a emancipação do trabalho.

Outra contribuição à discussão sobre o tema da emancipação ligada ao trabalho é possibilitada pela psicodinâmica do trabalho. Sem querer entrar numa descrição detalhada (sendo uma temática que não será tratada sucessivamente) a psicodinâmica do trabalho foi desenvolvida no contexto organizacional, tendo como objeto de estudo a superação do sofrimento psíquico causado pelo trabalho e da sua capacidade de conseguir desgastar os sujeitos desestabilizando a sua identidade (DEJOURS, 2005). A Psicodinâmica do Trabalho se propõe então a estudar o espaço que separa um comportamento livre, que possa permitir a transformação da realidade ao redor dos sujeitos segundo seus desejos e prazer, e um comportamento pré-determinado fora do alcance de tais sujeitos. Baseando-se nos conceitos ergonômicos de trabalho prescrito e de trabalho real, é na distância entre estes dois que ocorre ou não a construção da identidade no trabalho (DEJOURS, 2000). 
A Psicodinâmica do Trabalho visa a coletividade de trabalho, assim suas intervenções são voltadas para a organização do trabalho aonde os sujeitos estejam submetidos. Elemento importante de análise psicodinâmica é a fala dos sujeitos, levantada através de grupos de discussão internos à organização, a qual permite a expressão das vivências de prazer e de sofrimento encontradas no trabalho, consentindo explicitar as estratégias utilizadas para lidar com o sofrimento. Com referência às intervenções de psicodinâmica, Lancman e Uchida afirmam que estas "[...] devem levar os trabalhadores a um processo ativo de reflexão sobre o próprio trabalho, de modo a permitir sua apropriação e emancipação, e a conduzir a uma reconstrução coletiva do trabalho" (LANCMAN e UCHIDA, 1993, p. 88). Como introduzido por Dejours (2009), o trabalho pode gerar o pior, até suicídio, mas também pode gerar o melhor, como prazer, auto -realização e emancipação.

Como em Marx, na Psicodinâmica do trabalho a emancipação é contraposta ao tema da alienação. Dejours dedica a este último argumento um sub-capitulo na obra "A banalização da injustiça social" através de uma discussão sobre estratégias de defesa contra o sofrimento, e ao tentar resolver o problema da alienação escreve com referência em outra obra: "[...] procurei sobretudo desenvolver a psicodinâmica do prazer no trabalho e do trabalho como mediador insubstituível da re-apropriação do sentido e da emancipação" (DEJOURS, 2000, p. 97).

A autonomia no trabalho, em oposição ao controle através da prescrição de tarefas, é assim uma questão importante na psicodinâmica do trabalho (DEJOURS, 2000; FREITAS, 2007) porque abre aos sujeitos espaço de deliberação sobre a organização, permitindo realizar plenamente a si mesmo no ambiente interno ao trabalho (PERILLEUX, 1998). Com este gancho, e introduzindo duas concepções de emancipação (associadas à temática da autonomia) Perilleux (1998) faz uma análise histórica até chegar nas teorias sócio-técnicas, aonde analisa que a autonomia tornou-se meio de regulação do trabalho flexível e exigência empresarial. Isso se traduziu, conseqüentemente, em necessidade de maior responsabilidade do operador, criando nele um aumento de insegurança. Examinando assim, se a autonomia pode ser ainda um real ideal da emancipação no trabalho, ele conclui que a autonomia pode manter todo o seu potencial de emancipação se desligado da temática da responsabilidade individual. 
Em geral, nas teorias levantadas até o instante, a visão da emancipação é entendida como $o$ ato de se livrar de algo negativo (no caso, a alienação e a condição social mais fraca), mas no presente trabalho desejamos introduzir a temática encarando a emancipação como uma ação que permite a uma pessoa ou a um grupo entrar em um estado de autonomia, pró atividade, livrando o próprio pensamento das barreiras presentes nas organizações, mas respondendo aos objetivos das mesmas, sem a presença de responsabilidade individual.

Não existe muita literatura com o termo "emancipação" utilizado com este último significado, menos ainda junto à temática da ergonomia. Na busca da literatura foi encontrado algum exemplo ligado aos assuntos do processo de trabalho em saúde (PIRES, 2005), do aprendizado organizacional e de tecnologia de informação. Cashman (2003) descreveu como o fato de se emancipar, procurando ir além das fronteiras comunicativas a fim de resolver problemas, permitindo expandir as capacidades e os conhecimentos, e aumentar a compreensão entre as pessoas, ajudando na construção de uma comunidade. Falando sobre tecnologia de informação Klein e Myers (1999) introduziram a emancipação como "[...] ajudar a eliminar as causas de alienação e dominação injustificada e, assim, aumentar as oportunidades para a realização do potencial humano" (KLEIN e MYERS, 1999, p. 69).

\section{3 - A temática da participação do trabalhador}

Considerando a falta de literatura sobre a temática de emancipação, como elemento positivo e incentivado pelas organizações, aonde os sujeitos consigam dar espaço à própria individualidade para agir pró-ativamente com a finalidade de alcançar objetivos positivos para si e para a empresa, o autor decidiu introduzir a temática da participação e o conceito de envolvimento.

Envolvimento e participação muitas vezes são utilizados como sinônimos, mas entrando, no significado específico, existem algumas diferenças. Através da busca em vocabulários foram encontradas as definições presentes no anexo $A$ (participação: ato ou efeito de participar; envolvimento: ação ou efeito de envolver ou envolver-se): 
Os significados mais apropriados para esta pesquisa são "Comunicar, fazer saber, informar, ter ou tomar parte em" da definição de participar e "Comprometer, enredar, incluir-se, comprometer-se" da definição de envolver. A diferença principal é que participar indica ação, enquanto envolver indica um estado. A ligação destas três temáticas é que o trabalhador emancipado compreende a necessidade de que seja participativo, envolvido, e enfim pró-ativo. Destas, o tema da participação é o mais desenvolvido pela literatura, sobretudo relacionado à temática da organização do trabalho.

Como será explicado sucessivamente, a evolução da importância do assunto da participação é estritamente relacionada à evolução da importância dos trabalhadores para as organizações. Nas últimas décadas assistimos a grandes mudanças na gestão das empresas, aonde o papel do trabalhador ganhou crescente consideração e importância. Hoje as políticas das empresas de maior sucesso passam obrigatoriamente por uma gestão acurada das pessoas que trabalham ou querem trabalhar nelas, criando departamentos dedicados e especializados exclusivamente na busca, seleção, contratação, treinamento e acompanhamento de funcionários (FISCHER 2002, ALBUQUERQUE, 2002).

Vivemos num período histórico no qual o conhecimento é considerado como o único recurso que pode criar uma contínua vantagem competitiva (DRUCKER, 1993) e na sociedade do conhecimento investir no talento humano e nas suas capacidades é um fator competitivo importante (FLEURY e OLIVEIRA JR., 2002). Obter trabalhadores de primeiro nível é hoje reconhecido como um fator de sucesso, e por isso as empresas estão investindo muitos recursos para conseguir atrair os melhores profissionais do mercado, existindo uma concorrência por profissionais que agreguem condições determinantes no diferencial de qualidade das empresas (LIMONGI-FRANÇA e ARELLANO, 2002). Esta mudança não investe exclusivamente nos níveis hierárquicos mais altos das organizações, mas em todos os seus níveis. O objetivo atual é conseguir encontrar o trabalhador mais adequado para cada tipo de trabalho a ser executado.

Uma gestão de pessoas eficaz deve permitir, através da identificação dos profissionais mais adequados, que sejam atendidas as necessidades organizacionais para viabilizar o desempenho e a sustentação da competitividade, 
mas constitui vantagem competitiva também saber desenvolver relações de trabalho satisfatórias que permitam reter as pessoas (FACCHINI e BIGNETTI, 2004).

Além de contratar e reter um "capital humano" (BECKER, 1983), o foco dos estudos modernos é promover o desempenho eficiente dos trabalhadores já contratados para que possam entregar os resultados de sucesso esperados e alcançar os objetivos e a missão da empresa.

Fischer (2002) descreveu cinco fatores condicionadores do modelo de gestão de pessoas: tecnologia adotada, estratégia da organização de trabalho, cultura organizacional, estrutura organizacional e fatores externos. Ele adicionou também:

O que se quer dizer é que, quanto mais os negócios se sofisticam em qualquer de suas dimensões - tecnologia, mercado, expansão e abrangência etc. -, mais seu sucesso fica dependente de um padrão de comportamento coerente com estes negócios (FISCHER, 2002, p. 13).

Podemos extrair que uma modalidade eficiente e eficaz de gestão das pessoas depende de fatores internos (dependentes da política estratégica da empresa) e externos (principalmente do mercado ou dos clientes). Com isso podemos entender como numa sociedade do final do século XIX e começo do XX, com todas as suas características e peculiaridades entre as quais a necessidade de produzir bens de massa ao menor preço, podia-se considerar o homem um simples complemento da máquina. Daquele período até hoje houve muitas mudanças (entre as principais: do mercado, da necessidade de uma produção com alta flexibilidade, da globalização, da maior instrução dos empregados, da servitização, de tipo institucionais e culturais, etc.) e tal modelo pode ser ainda possível apenas em poucos nichos de empresas. Mesmo assim, o pressuposto de linearidade, de controle absoluto (também sobre os trabalhadores), foi ultrapassado e hoje dificilmente é possível colocar homens e robôs na mesma categoria (ABRAHÃO et al., 2009)

A visão atual está em processo de evolução, e o empregado não é mais considerado como um recurso produtivo a par de maquinários que precise assegurar estabilidade e ótimo rendimento das tarefas pré-estabelecidas, mas sim está se transformando em um crescente influenciador do sucesso da empresa (FISCHER, 2002).

Com isso ganham crescente importância temática, como a motivação e a participação do trabalhador: "A motivação tem sido vista como uma saída para melhorar o desempenho profissional no que diz respeito tanto à produtividade 
quanto à saúde organizacional e satisfação dos trabalhadores" (CASADO, 2002, p. 257).

Existem várias contribuições; entre as mais famosas, de Maslow (1954), Likert e Herzbergh (HERTZBERG, MAUSNER e SNYDERMAN, 1959). Motta e Vasconcelos (2002), analisando tais autores, relataram que estas teorias motivacionais prescreviam um estilo mais democrático de liderança, o qual permite a participação dos funcionários e o enriquecimento das tarefas.

A participação do trabalhador, mesmo com algumas limitações (SMITH, 2006), ganha então uma importância fundamental seja como aspecto motivacional para o empregado, seja como elemento que permite vantagem competitiva para a empresa através dos seus conhecimentos, sendo a criação de conhecimento organizacional um processo participativo (FLEURY e OLIVEIRA JR., 2002).

No sub capítulo sucessivo serão apresentadas as principais teorias organizativas sobre a importância do assunto da participação, deixando claro quais foram os princípios e os elementos que levaram as empresas a ter maior consideração do papel do trabalhador.

\subsection{1 - A participação do trabalhador nas principais teorias da organização do trabalho}

\section{“Organização Cientifica do Trabalho" (OCT)}

Inovar, na organização do trabalho, ocorre desde o começo do período industrial ao aperfeiçoar as soluções organizacionais com o objetivo de maximizar a utilização dos próprios recursos para conseguir maior output e condições vantajosas para o mercado. Em tal sentido que a passagem do artesanato à fabrica, através dos conceitos de especialização das tarefas e padronização dos componentes dos produtos, decretou o começo de uma mudança de visão, aonde todos os input de entrada viraram recursos a serem maximizados.

Mas foi com Taylor e a teoria da "Organização Cientifica do Trabalho" (OCT) que tal processo de racionalização teve seu ápice. As principais características destas teorias, descritas por Bonazzi (2002), são três: 
- concentrar a atenção sobre como aumentar a produtividade e o rendimento de homens e maquinários,

- Recolher e racionalizar as linhas de autoridade na empresa organizando o trabalho sobre base técnica, e não mais deixada à iniciativa de artesões ou operários. Introdução conjunta de sistemas contáveis e de programação, definindo também as linhas de comando.

- Utilização da ciência como critério de ação e de legitimação das escolhas efetuadas.

Resumindo, houve uma clara separação entre quem pensa (e gerencia o trabalho), e quem executa o trabalho (ANTUNES, 2003). A participação do trabalhador é nula: o operário chegou nesta época a tornar-se um recurso produtivo, desapropriado do seu saber fazer e sem poder dar sua contribuição original ao trabalho, alienando-se dele (MARX, 2002). Segundo Zarifian (1990) os operários renunciavam ao poder em troca de um salário maior, o que tornou seu trabalho abstrato e generalizável.

Ainda segundo Zarifian (1990), o Taylorismo apresentava uma grande limitação, ou seja, não levava em consideração a subjetividade das pessoas. O enfoque era deixado apenas na produtividade, sem interessar-se por argumentos como a qualidade e a diferenciação dos produtos finais, e se adaptava bem naquelas atividades que implicavam uma forte dependência da mão-de-obra operária, mas não em outras (como em indústrias de processo contínuo) sobretudo se a mão-deobra indireta (intelectual) representasse uma boa parte da força-trabalho. $O$ Taylorismo foi bom até a introdução de comportamentos cooperativos.

\section{Escola das Relações Humanas}

Os estímulos econômicos que perderam efeito sobre os trabalhadores, 0 reconhecimento da presença do senso de afetividade e responsabilidade de trabalho de grupos informais, e que a produtividade é estreitamente ligada à satisfação mo trabalho, foram as bases para o nascimento no fim dos anos 1920 da Escola das Relações Humanas (MOTTA e VASCONCELOS, 2002).

Significativa para tal fim é a seguinte passagem feita por Casado:

[...] A fragmentação e a rotinização das tarefas reduzem a possibilidade de o trabalhador sentir satisfação no trabalho, o que faz com que a busquem em outro lugar. Assim, o 
relacionamento com os colegas aparece como uma possibilidade de satisfação. O novo modelo indicava como estratégia motivacional: fazer com que os empregados se sentissem importantes, abrir canais de comunicação para que fossem ouvidos, e permitir que interferissem e opinassem no modo de executar seu trabalho (CASADO, 2002, p.250).

Para tal Escola de pensamento, o homem não pode ser considerado como simples força de trabalho e ser obrigado a realizar as tarefas sem conhecer os fins, mas precisa ser considerado na sua natureza humana.

Existem duas fases principais na evolução da Escola das Relações Humanas (BARTEZZAGHI, 2010):

- Numa primeira fase são propostas melhorias e integrações ao OCT, afirmando que para aumentar a produtividade precisamos considerar as características pessoais e sociais dos trabalhadores, e adaptar as tarefas ao trabalhador. O expoente principal foi Elton Mayo, sobretudo através dos experimentos de Hawthorne (ANFOSSI, 1971) nos quais, além de reconhecer a importância de considerar aspectos pessoais do trabalhador para obter resultados melhores, reconhece como a atenção dos chefes aos trabalhadores e a participação deles em programas de inovação pode causar um aumento da produtividade temporária.

- A segunda fase, do período após a segunda guerra mundial, é caracterizada por assuntos como a motivação (HERTZBERG, MAUSNER e SNYDERMAN, 1959; MASLOW, 2003) e o comportamento no trabalho como a teoria X e Y (McGREGOR, 1960).

Mesmo começando a entender as potencialidades da participação do trabalhador, a Escola das Relações Humanas considera como muito importante a percepção, o lado humano dos trabalhadores para conseguir um aumento da produtividade, ou seja, se preconiza que os trabalhadores devam participar da decisão que origina as tarefas que executa (MOTTA e VASCONCELOS, 2002). Sobretudo através dos experimentos de Heathorne, esta escola de pensamento começou a entender as potencialidades na melhoria temporária da produtividade (embora limitada temporariamente) da participação dos trabalhadores, embora seja uma das muitas variáveis para motivar o trabalhador. A temática da participação em Maslow (2003) é encontrada no terceiro "nível" do seu modelo, aquele das necessidades sociais. Ele entende como o gerenciamento autoritário insulta a dignidade do trabalhador, 
auspiciando assim para as necessidades sociais dos trabalhadores de introduzir uma gestão participativa.

\section{Lean Production e Toyotismo}

A partir dos anos 50, pressões competitivas, crise da produção de massa, e a particular situação do Japão, permitiram a introdução de novas teorias baseados no melhoramento contínuo, no Just in Time, Total Quality Management, Total Productive Maintenance, Business Process Reengineering, etc. A empresa precursora foi a Toyota e a expansão de tais teorias gerenciais no resto do mundo ocorreu entre os anos 60 e 70 (BARTEZZAGHI, 2010).

Como explicado por KRAFCIK (1988) com a Toyota foi possível adicionar as teorias do Scientific Management à aplicação de grupos de trabalho para aumentar ainda mais a produtividade. Os operadores são treinados para uma alta variedade de tarefas e habilidades (ex: controle de qualidade) com a responsabilidade de continuar aumentando a performance. Este tipo de organização não requeria muitos managers de nível médio e possuía baixos estoques, que permitiam livrar recursos para a empresa. Ford construiu as primeiras fábricas de produção de massa partindo do conceito de que uma maior eficiência seria alcançada minimizando o tempo entre o inicio e o fim da produção. Toyota conseguiu transformar esta padronização em Just in Time (JIT) introduzindo flexibilidade, possibilidade de produzir grande variedade de produtos utilizando as metodologias do continuos-flow, entre os quais a minimização dos tempos de set-up e diminuição do tamanho dos lotes de produção.

A participação do trabalhador nesta fase é ativa: ele tem que cuidar e permitir uma resposta rápida às variabilidades da produção, para aumentar também a flexibilidade da produção ao mercado. Diferentemente da via taylorista norte-americana que proporcionou a destruição dos saberes operários complexos e da decomposição em gestos elementares, na via japonesa os trabalhadores foram desespecializados, tornando-se de fato um "trabalhador multifuncional" (CORIAT, 1994).

Nesta fase não muda a idéia de que o homem é um recurso, a diferença para o Taylorismo é que além da força física, são aproveitadas também as capacidades e as idéias do trabalhador, como explicado por Coriat: 
[...] Este movimento de desespecialização dos operários profissionais e qualificados, para transformá-los em trabalhadores multifuncionais, é de fato um movimento de racionalização do trabalho no sentido clássico do termo. Tratase aqui também, como na via taylorista norte-americana, de atacar o saber complexo do exercício dos operários qualificados, a fim de atingir o objetivo de diminuir os seus poderes sobre a produção e de aumentar a intensidade do trabalho (CORIAT, 1994, p.53).

\section{$\underline{\text { Teoria dos sistemas sócio-técnicos }}$}

Outra teoria organizativa importante é a do sistema sócio-tecnico. Esta nasce ao começar dos anos $50 \mathrm{com}$ as pesquisas desenvolvidas do Tavistock Institute of Human Relations de Londres, como resposta a um contexto econômico de crescente dinamicidade e a um interesse maior pelo lado social nas empresas (BARTEZZAGHI, 2010). Emery e Trist (1974) descreveram os principais aportes desta teoria, ou seja, a introdução de: soluções organizativas inovadoras (como os grupos autônomos de trabalho), princípios de projetos organizativos inovadores (ex. job design), novos métodos de análise organizativa, e da metodologia de "pesquisaação".

Significativas foram as pesquisas desenvolvidas nas minas inglesas, as quais levaram a novos ensinos, como explicado por Bartezzaghi (2010):

- a impossibilidade de gerenciar e intervir de modo separado sobre o sistema técnico e social (sócio-technical system),

- é possível individualizar soluções organizativas diferentes, embora uma mesma solução tecnológica adotada (organizational choice),

- é útil envolver os trabalhadores na projeção da solução a ser adotada (participant design),

- necessidade de experimentar adequadamente antes de implementar uma solução (action research),

Para otimizar o próprio sistema e para aumentar também a produtividade, foram propostos novos princípios de projeção organizativa. O grupo começa a obter uma importância central sobre o indivíduo, como considerar as atividades em lugar de prescrever tarefas detalhadas. Nesta fase é incentivado o aumento da variabilidade, o aumento das funções desenvolvidas do grupo (aumentando assim a capacidade de resposta às possíveis variabilidades) e da auto-regelação do mesmo. O 
trabalhador se transforma assim em complemento aos maquinários, e não simples extensão (BARTEZZAGHI, 2010).

A participação dos funcionários é a base desta teoria e ganha então fundamental importância. Os limites de tal teoria foram encontrados na elevada responsabilidade dos operadores com a conseqüente alta possibilidade de risco por parte da empresa, e as reações das estruturas hierárquicas e de staff (BARTEZZAGHI, 2010).

É a partir da escola sócio-técnica que o trabalhador começa e exercer um papel ativo muito importante no sucesso da organização.

\section{$\underline{K n o w l e d g e ~ M a n a g e m e n t}$}

Última teoria organizativa a ser analisada é do Knowledge Management. Esta teoria nasceu devido ao fato que a competitividade, o contexto turbulento, a inovação, levam a ver o conhecimento como um recurso (o capital intelectual) a ser gerenciado como os recursos econômicos, as pessoas e as matérias primas (BARTEZZAGHI, 2010).

Segundo Bartezzaghi (2010) existem alguns pontos críticos na gestão do conhecimento:

- É difícil compartilhar e capitalizar o que se conhece,

- Existem desafios devidos à introdução contínua de novas tecnologias,

- Os conhecimentos pertencem ao Knowledge worker e não a organização, e estes são dificilmente retidos,

- O conhecimento torna-se logo obsoleto se não desenvolvido e discutido continuamente.

Por isso que segundo Bartezzaghi (2010) é necessário um esforço sistemático para encontrar, organizar e disponibilizar o capital intelectual necessário para a organização. É necessário também alimentar uma cultura de aprendizagem contínua e o compartilhamento do conhecimento. 
Segundo Nonaka e Takeuchi (1995) existem duas dimensões a ser considerada, a natureza dos conhecimentos e aonde estes residem (no indivíduo, no grupo, na organização e na dimensão interorganizacional).

Considerando a primeira dimensão, o conhecimento é distinguido entre o explícito, formal que pode ser codificado e transmitido na organização através de documentos, e a tácita, baseada na experiência pessoal e compreende competências práticas, experiências individuais e soluções criativas.

Ainda segundo Nonaka e Takeuchi (1995), as formas de interação entre o conhecimento tácito e conhecimento explícito (e como conseqüência também entre indivíduo e organização) resultam em quatro processos de conversão do conhecimento que constituem o modelo SECI (espiral do conhecimento), como descrito na ilustração 4 .

\begin{tabular}{|c|c|c|c|}
\hline & & \multicolumn{2}{|c|}{ Em conhecimento... } \\
\hline & & ...tácito & ...explícito \\
\hline \multirow{4}{*}{ 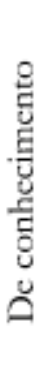 } & & Socialização & Externalização \\
\hline & "ֶֶّ & $\begin{array}{l}\text { (...cria conhecimento } \\
\text { compartilhado) }\end{array}$ & $\begin{array}{l}\text { (...cria conhecimento } \\
\text { conceitual) }\end{array}$ \\
\hline & : & Internalização & Combinação \\
\hline & 哭 & $\begin{array}{c}\text { (...cria conhecimento } \\
\text { operacional) }\end{array}$ & $\begin{array}{c}\text { (...cria conhecimento } \\
\text { sistêmico) }\end{array}$ \\
\hline
\end{tabular}

llustração 4 - Formas de interação entre conhecimento tácito e conhecimento explicito.

Fonte: Adaptado de Nonaka e Takeuchi (1995).

O conhecimento então passa do indivíduo ao grupo, à organização, e vice-versa através estes ciclos.

O trabalhador ganha importância no Knowledge Management, e a sua participação é fundamental, sobretudo ativa em tal processo de construção do conhecimento na organização: "O trabalho não é mais o conjunto de tarefas associadas descritivamente ao cargo, mas se torna o prolongamento direto da competência que o indivíduo mobiliza em face de uma situação profissional mais mutável e complexa" (FLEURY, 2002, p.54). 


\subsection{2 - Ação organizativa e a contribuição de Maggi}

Menos estudada na literatura da organização do trabalho tradicional, particular contribuição à temática da participação pode ser obtida através da teoria da Ação Organizativa.

Como escrito por Maggi (1991), não há apenas uma disciplina que estuda o trabalho organizado, existindo várias modalidades de concebê-lo. Ele propõe três posições para entender a realidade de trabalho organizado:

- Como sistema predefinido ao sujeito agente e às atividades, aonde os sujeitos devem se adaptar ao sistema (lógica do sistema predominante).

- Como exclusivo produto das interações subjetivas, independentes do sistema (lógica do ator).

- Como um processo de ações e decisões aonde não existe separação entre sistema e sujeito, porque o sistema é o processo e o sujeito é elemento integrante.

Esta última modalidade é própria da teoria da ação organizativa. O autor pai de tal teoria pode ser considerado Weber (2004), que define a organização como uma forma de agir social e um agir humano com sentido intencional.

$\mathrm{Na}$ sucessiva evolução do conceito, Barnard (1947) define o sistema organizativo como um sistema de atividades ou forças pessoais intencionalmente coordenadas. Em tal sentido, uma organização formal que represente o sistema organizativo nasce sempre depois da criação de uma organização espontânea e de tipo informal, e a comunicação organizativa é o tecido conectivo da organização.

Ulterior evolução ocorreu com Simon (1947), que introduz o conceito de racionalidade intencional limitada, no qual ao homem economicus é contraposto o homem administrativo, que tem que decidir num ambiente aonde não existem certezas. A estrutura torna-se o modo como são controladas e coordenadas as decisões e as ações.

Sucessivamente Thomson (1967) desenvolve o estudo das organizações como sistemas indeterminados que enfrentam a incerteza, mas ao mesmo tempo, sujeitas ao critério da racionalidade e assim necessitadas de determinação e certeza. 
Chegando enfim em Maggi (2006) que, através da lógica da ação organizativa, explica que o sistema de trabalho organizado é um processo de decisões e ações orientadas a objetivos e resultados esperados. A lógica da ação organizativa e do sistema como processo se baseia na idéia da "racionalidade intencional e limitada", que guia ao mesmo tempo o processo com relação a objetivos e valores; cada elemento do processo é variável porque é fruto de escolhas. No processo podem-se distinguir analiticamente diferentes componentes: as atividades, independentemente dos sujeitos que o desenvolvem; o desenvolvimento das atividades por parte dos sujeitos; os conhecimentos técnicos e os resultados esperados. Podem-se avaliar então as recíprocas congruências entre os componentes do processo de trabalho organizado.

Baseado em tais teorias, Maggi (2006) explica que a organização por sua vez pode subtrair ao indivíduo uma parte da sua autonomia de decisão, podendo assim produzir doença por meio da sua característica intrínseca de constrangimento. Uma ação cooperativa, por exemplo, é uma ação organizativa que provoca constrição, pois inevitavelmente reduz a liberdade das decisões individuais.

Sabendo que cada elemento do processo é corrigível e modificável (também os objetivos), são possíveis projeções e reprojeções que tendam a reduzir o constrangimento, para assegurar estados preferenciais de bem estar. Reconhecendo que os trabalhadores têm conhecimento direto sobre o próprio trabalho, o melhor modo para reduzir o constrangimento (ou seja, quando a organização subtrai ao individuo uma parte da sua autonomia de decisão) é agir no sentido da emancipação dos trabalhadores, para que possam ter maior influência nas decisões sobre o seu trabalho e a construção da sua saúde. O envolvimento das pessoas requer a constituição de espaços nos quais elas possam reforçar a cooperação e a deliberação sobre questões relativas ao trabalho.

Com o objetivo de passar das muitas práticas de leitura das situações de trabalho para um método de análise organizativa, Maggi (1991) propôs o método das Congruências Organizacionais. 
- Organização do trabalho - Método das Congruências Organizacionais

O Método das Congruências Organizacionais, testado e validado em vários contextos organizacionais, é proveniente da Teoria da Ação Organizacional (MAGGI, 1991). Cada situação de trabalho é resultado de decisão e ação, os quais são escolhas de metas, de coordenação das atividades, coordenação de pessoas para a realização das atividades, e de conhecimentos técnicos. Nasce e se desenvolve segundo um percurso interdisciplinar, com insumos econômicos, sociológicos, psicológicos e jurídicos, é um método de análise que descreve e interpreta a situação organizacional nos seus elementos de ação e de decisão. A análise de uma realidade organizada, como por exemplo no caso de atividades em laboratório em um hospital (RULLI et al., 2004), ou a projeção de uma nova realidade, seguem um percurso lógico, no qual se distinguem três etapas principais: a escolha do objeto de estudo, a descrição, e a interpretação.

O método das congruências prevê e analisa os possíveis riscos que podem originarse em cada uma das ações do processo organizacional (ações estruturais, técnicas e institucionais). A análise comparativa entre os componentes analíticos do processo organizacional permite detectar os elementos de constrangimento organizacional que representam a condição de perigo potencial para a saúde dos operadores envolvidos no processo de exame.

Pode-se, portanto, avaliar criticamente as escolhas estruturais e técnicas em relação ao objetivo, as relações entre os dois momentos de estruturação (das tarefas e social), as relações entre as estruturas e os conhecimentos técnicos; ou seja, podemos analisar as congruências organizacionais do processo de trabalho examinado.

Maggi (2006) propõe uma participação direta dos trabalhadores em processos de melhoria, não enxergando-os apenas como simples input de informação para as organizações. Sabendo que os trabalhadores têm o conhecimento operativo das próprias atividades, este autor identifica que os principais atores em um processo de melhoramento são os próprios trabalhadores. Com base na metodologia por ele introduzida, das congruências organizacionais, ele se propõe como pesquisador apenas a ensinar uma metodologia para que os próprios operadores a implementem. 


\section{3 - PROPOSIÇÕES, OBJETIVOS E RELEVÂNCIA}

Após a definição da questão de pesquisa (relembrando: "Agindo, (1) no grau de envolvimento/participação/emancipação dos trabalhadores e (2) no nível aonde se situa a discussão ergonômica na organização; é possível obter resultados ergonômicos mais amplos e duradouros no tempo?") e a escolha do projeto prático a ser analisado, o primeiro período da pesquisa foi caracterizado por buscas bibliográficas e pela inicial participação ativa nos projetos ergonômicos desenvolvidos na instituição em análise.

Antes da definição das proposições, dos objetivos, e da explicação de qual a relevância da presente dissertação, foi necessário ter bem claro qual foi a visão dos pesquisadores sobre $\mathrm{o}$ trajeto de ações ergonômicas anteriores e conseqüentes ao "Programa de Cooperação Técnica".

\section{1 - Visão dos pesquisadores sobre o trajeto de ações ergonômicas no HU- USP}

A entrada do grupo de pesquisadores a partir do ano 2000 foi através do desenvolvimento de estudos de AET. Este primeiro passo, embora era reconhecido que tais estudos não resolviam os problemas estruturalmente na instituição, trazendo melhorias quase exclusivamente locais, permitiu que a ergonomia fosse conhecida no hospital e que a relação com a instituição se fortalecesse. A crescente sensibilização na temática e o reconhecimento que os trabalhos de AET traziam sugestões de melhorias reais foram a alavanca para que o hospital começasse a confiar na equipe da Escola Politécnica e abrir a possibilidade que ela propusesse o "Programa de Cooperação Técnica", uma ação ergonômica mais estruturada e num nível mais estratégico. Entrando nos detalhes deste programa, as ações de psicodinâmica e de AET representaram a continuação das ações antecedentes, enquanto o Grupo de Treinamento e Capacitação (GTC) e o Comitê de melhorias (CM) foram um grande avanço com o objetivo de trazer melhorias de largo porte na organização, agindo além da área operativa. 
Com a introdução do GTC, o objetivo foi de formar internamente pessoas em assuntos ergonômicos, de forma a obter um grupo capacitado e apto a disseminar a temática no próprio âmbito de trabalho. Além disso, os trabalhos conclusivos do curso, uma vez realizados na prática, teriam constituído um ótimo meio para promover a temática entre os trabalhadores das áreas não envolvidas. Um aspecto fundamental teria sido incluir em todos os trabalhadores a consciência que eles mesmos poderiam ter um papel ativo para que as melhorias aconteçam.

Paralelamente ao GTC, a construção do CM permitiria criar um meio formal e organizativo para que as sugestões de melhorias (seja das condições de trabalho como da eficiência e produtividade) pudessem ser levadas aos mais altos níveis da organização até aqueles com poder para a tomada de decisões, sobretudo a Superintendência. Em outras palavras, as propostas de melhorias seriam coletadas por pessoas sensibilizadas no assunto vindas principalmente da área operacional (e que partindo da uma preposição inicial, são as melhores conhecedoras do próprio trabalho), e o CM teria a tarefa de alinhar tais exigências do trabalho com as estratégias do topo da organização.

Com tal propósito, além de permitir a sensibilização dos trabalhadores e a ajuda prática para o desenvolvimento dos projetos, a equipe de pesquisadores procurou sempre envolver a Superintendência, para que esta pudesse apoiar e permitir o efetivo alinhamento entre estratégia e planos operacionais.

\section{2 - Objetivos}

Partindo de tal visão, o primeiro objetivo é o seguinte:

Objetivo 1 Desejou-se analisar os benefícios do desenvolvimento de ações ergonômicas que estejam inclusas numa visão mais abrangente da organização e em um nível mais elevado nas tomadas de decisão.

Para obter resultados ergonômicos duradouros, além de estudar situações locais, em sua maioria executadas em lugares operacionais, é necessário agir no sentido de elevar a temática em níveis mais altos da estrutura organizacional. Em particular, 
introduzir um órgão formal na estrutura organizacional da empresa, em contato com a gerência da mesma, permitiria que a ergonomia pudesse ganhar força e importância na organização, além de permitir considerar nas análises também as variáveis de nível macro.

Partindo das experiências em análise ergonômica em situações locais e no plano operacional, e entendendo os limites das mesmas, o autor quis envolver a ação ergonômica em um nível mais macro, entregando com a presente dissertação os resultados. Pretendeu-se acompanhar o desenvolvimento de ações ergonômicas do $\mathrm{CM}$, apresentando através de uma fase de análise e avaliação do mesmo, pontos de sucesso e de fraqueza. Particular atenção é posta na entrega de feedbacks sobre o grau de ligação e integração entre o plano estratégico e o plano operacional da organização. Tentourse agir também no lado cultural da empresa, fazendo entender como a ergonomia vai além da legislação e dos custos sociais, mas também como meio de melhoria e de aumento do bem-estar na organização. É de fundamental importância a postura da diretoria, a qual dependendo do seu grau de envolvimento pode melhorar, ou mesmo piorar as condições ergonômicas de trabalho em toda a organização.

Com relação á organização do trabalho é importante que a cúpula estratégica da organização esteja totalmente envolvida e permita que a temática da ergonomia seja elevada e contemplada nas próprias decisões estratégicas. Do outro lado é importante que a organização busque dar as melhores bases para que os trabalhadores de todos os niveis possam oferecer contribuições para melhorar as próprias condições de trabalho e o desempenho global da organização.

Objetivo 2: Buscou-se descrever e analisar os benefícios de um papel proativo dos trabalhadores nos vários níveis da organização, numa intervenção ergonômica.

Os trabalhadores (de todas as áreas de atuação) são os maiores conhecedores das situações de trabalho. Envolvê-los através de uma participação direta nos estudos ergonômicos permitiria levantar com maior facilidade todas as informações ligadas às atividades e, como conseqüência, os problemas reais das situações de trabalho. 
Deste modo, as mudanças ganham uma maior porcentagem de sucesso, além de serem aceitas com maior facilidade pelos trabalhadores, engajados em tal processo.

Contando com a cooperação e o envolvimento dos trabalhadores é possível criar um núcleo, que fique na memória do hospital, dos trabalhadores e dos gestores para que os conceitos permaneçam na organização ao longo do tempo.

Foi possível chegar também a definir um sub-objetivo que se revelou um bom meio para alcançar os dois objetivos principais.

Sub-objetivo geral: Pretendeu-se formalizar juntos aos diferentes atores os impactos derivados da ação ergonômica na instituição pesquisada.

O projeto de cooperação entre o departamento de Engenharia de Produção (apoiado pela Fundação Carlos Alberto Vanzolini) e o Hospital Universitário foi composto por diferentes ações, seja de tipo ergonômico como de psicodinâmica, além de pesquisas anteriores de ergonomia através de intervenções menos estruturadas, sobretudo de AET. Chegando a um ponto avançado de tal projeto, pretendeurse coletar e resumir as informações derivadas de todo este projeto de ergonomia, levantando os pontos fortes e fracos de tal pesquisa e contextualizando-os com a tipologia específica da empresa estudada.

\section{3 - Formulação das proposições}

Em concomitância com a definição dos objetivos foram individuadas as proposições a serem verificadas através deste trabalho. As principais proposições são duas:

Proposição 1: Agir no sentido de elevar a temática da ergonomia em níveis de poder mais altos na organização, e uma atuação junto a cúpula estratégica possibilita obter resultados ergonômicos duradouros no tempo e de maior alcance.

Elevando a temática da ergonomia até que esta seja considerada ativamente na cúpula estratégica da empresa permite que sugestões e conhecimentos de trabalho 
típicos da base hierárquica da organização e do lado operacional possam chegar aos níveis de decisão. Com estas sugestões chegando de forma esquematizada à direção, também através de um meio organizacional como o $\mathrm{CM}$, podem ser adotadas políticas capazes de aproveitar idéias numerosas e ricas, melhorando o bem estar das pessoas e aumentando a produtividade. Entendendo tais benefícios a diretoria é incentivada na continuação de tal experiência.

Proposição 2: Existe relação entre a emancipação dos trabalhadores, o sucesso de uma intervenção ergonômica e a permanência da temática da ergonomia na organização ao longo do tempo.

Além da participação, o trabalhador emancipado consegue ter uma postura proativa, a qual permite uma busca contínua de informações úteis para propor e tentar implementar melhorias no próprio lugar de trabalho, mesmo sem ajuda externa. Ter controle sobre o próprio trabalho e poder melhorá-lo partindo do surgimento de situações críticas aumenta a flexibilidade e conseqüentemente o nível do próprio serviço. Com um aumento da satisfação do trabalhador no próprio serviço, decorrente de um cuidado direto nas específicas situações e da adoção de uma cultura do bem-estar, os funcionários trabalham melhor e oferecem um serviço de melhor qualidade para a comunidade que utiliza a estrutura. A presença de trabalhadores "emancipados" elimina a necessidade constante da presença de um especialista com conhecimentos técnicos em ergonomia para resolver problemas, porque estes poderiam ser individuados e corrigidos imediatamente após seu surgimento. Emancipar o trabalhador pode ser uma variável importante em determinadas estruturas organizacionais.

Buscou-se portanto entregar casos práticos e dados qualitativos investigando e tentando compreender a temática do envolvimento até a emancipação do trabalhador ligado as intervenções de ergonomia. Entendendo que, sobretudo em nível operacional, a saída do pesquisador após qualquer intervenção gera uma perda de importância percebida da temática da ergonomia na empresa, pretende-se confirmar (ou não) que uma efetiva emancipação dos trabalhadores é um dos meios que permitem que o cuidado com a saúde do trabalhador permaneça presente na instituição. Foram buscados também quais meios permitiriam que os funcionários se 
emancipassem e em quais fases seria necessária a presença ou não de um profissional da área da ergonomia.

\section{4 - Relevância}

Enquanto a importância da participação dos trabalhadores é uma temática com sólida base literária, sobretudo nas teorias organizacionais, e aplicada também em assuntos de ergonomia, pouco foi estudado sobre as oportunidades que uma estratégia de emancipação do trabalhador poderia promover nas organizações. Com a presente pesquisa procurou-se focalizar esta temática aplicada a assuntos ergonômicos, com o objetivo de introduzi-la e abrir uma discussão sobre os benefícios e eventualmente os limites que pode comportar a sua aplicação. Um caso real vai permitir que saiamos de uma discussão exclusivamente teórica e permitirá entregar uma base concreta para ser discutida e validada em outras situações.

Outra importante contribuição deste trabalho é descrever e permitir a difusão de uma experiência de aplicação ergonômica numa instituição pública brasileira na área da saúde, desenvolvida ao longo de vários anos e composta de múltiplos passos. Grande importância neste contexto será dada à relação entre as políticas estratégicas e o que é desenvolvido na realidade do plano operacional nas organizações, lugar no qual a aplicação de ações ergonômicas normalmente tem sede. Além de poucos casos de aplicação macroergonômica, este último assunto não é muito discutido na literatura ergonômica brasileira sendo que o foco de aplicações ergonômicas é geralmente a situação local, ou o singular problema, e por isso desejou-se dar uma contribuição. Acredita-se que a presente pesquisa, além do possível avanço nos conhecimentos ergonômicos, poderia ser uma ótima base a ser considerada na fase de planejamento para novos estudos ergonômicos em situações similares, aumentando assim a probabilidade de sucesso dos mesmos. 


\section{4 - ASPECTOS METODOLÓGICOS - PESQUISA AÇÃO}

Nas abordagens da ergonomia mais tradicionais, as pesquisas foram praticadas através de observações individuais com um olhar externo à execução operacional. Em tempos mais recentes, novas pesquisas ergonômicas (sobretudo partindo da abordagem francófona e toda a vertente da ergonomia participativa) começaram a privilegiar observações participativas entre os olhos dos pesquisadores e os conhecimentos dos trabalhadores na execução prática de projetos reais.

Baseado em tal evolução da ergonomia, foi natural a escolha do autor para que a dissertação tenha fundamentos práticos através da participação do autor de um projeto com orientação metodológica de pesquisa-ação (PA).

Em paralelo ás experiências recebidas através da participação na PA, grande impacto na construção de conhecimento neste escrito foi devido ao levantamento de muitos dados qualitativos, principalmente através de entrevistas semi-estruturadas.

A participação prática de PA foi essencial para o estudo,embora isso não seja o foco da dissertação e não será descrita em todas as fases, sendo mais um meio para chegar nos objetivos do autor. Os resultados das entrevistas, ao contrário receberam uma posição de grande respaldo.

Uma primeira parte segue exclusivamente metodológica com a apresentação de literatura sobre PA e sobre levantamento de dados (focando nas entrevistas semiestruturadas), uma segunda parte discute do método e dos principais passos que 0 autor desenvolveu para chegar na confirmação (ou não) das preposições de pesquisa.

\section{1 - A Pesquisa Ação}

Segundo Thiollent a pesquisa-ação é:

[...] um tipo de pesquisa social com base empírica que é concebida e realizada em estreita associação com uma ação ou com a resolução de um problema coletivo e no qual os pesquisadores e os participantes 
representativos da situação ou do problema estão envolvidos de modo cooperativo ou participativo (THIOLLENT, 2004, p 26).

Segundo Checkland e Holwell (1998) é um método colaborativo para testar novas idéias e implementar ações para a mudança. A PA envolve a participação direta em processos dinâmicos de pesquisa, enquanto as ações do pesquisador são monitoradas e avaliadas com o objetivo de melhorar a prática.

Esta abordagem é muito útil porque reconhece que existem vários olhares, e diferentes saberes (THIOLLENT, 2004) sobre as oportunidades de melhoria, e considerar todos estes pode permitir chegar ao máximo potencial na resolução da demanda de pesquisa inicial (COUGHLAN e COGHLAN, 2002).

É interessante notar como há analogias entre a ergonomia (de origem francófona) e a PA, ambas se baseiam em estudos de campo de atividades reais que, por natureza e por causa das variabilidades, são imprecisas, incertas e às vezes instáveis. Mesmo assim a PA, como a ergonomia, é uma abordagem científica porque focaliza sobre observações e estudo dos efeitos dos comportamentos humanos sobre o sistema na geração das mudanças (COUGHLAN e COGHLAN, 2002).

Existem também elementos em comum entre a PA e a ergonomia participativa. Com base nos textos que discutem de PA de Gummesson (2000), McDonagh e Coghlan (2001), podem ser encontrados alguns elementos em comum com a ergonomia participativa, sendo que ambas as pesquisas são:

- "em ação" e não "sobre a ação", ou seja, o estudo da resolução de problemas é feito junto com quem experimenta diretamente estes problemas e vivencia diariamente tal trabalho;

- participativas e interativas, sendo que os sujeitos do sistema não são objetos de estudo, mas atores que podem influenciá-lo;

- concorrentes com a ação, em particular para a organização, a ação é mais efetiva se construída simultaneamente com um corpo de conhecimentos científicos;

- direcionadas para a resolução de problemas que aparecem na realidade,

$\mathrm{Na}$ atual PA será tomado particular cuidado na direção de algumas ameaças de validade que precisam ser levadas em consideração. A principal destas é a 
possibilidade de falta de imparcialidade por parte do pesquisador, o qual precisa procurar sempre construir a pesquisa junto a todos os atores presentes no sistema estudado (COUGHLAN e COGHLAN, 2002).

$\mathrm{Na}$ aplicação de uma PA na prática existem varias fases a ser seguidas.

$\mathrm{Na}$ fase de planejamento da PA é necessário encontrar uma organização com um problema real de interesse de pesquisa e importância gerencial. Junto a isso, nesta fase, é essencial na escolha da empresa a presença de um contato na organização cliente que possa permitir o envolvimento dos membros chave da organização (COUGHLAN e COGHLAN, 2002).

Uma vez escolhida a instituição sede do estudo é possível planejar as primeiras ações a serem desenvolvidas. Torna-se necessário argumentar que a filosofia subjacente da PA é que não sejam planejadas com antecedência todas as fases da ação; sendo que pequenos planejamentos acontecem no final de cada fase (THIOLLENT, 2004). Esta é a motivação principal da necessidade de desenvolver ciclos de PA.

Existem na literatura vários modelos propondo ciclos de PA (POSCH e SOMEKH, 1993; KUHNE e QUIGLEY, 1997; ALTRICHTER; COUGHLAN e COGHLAN, 2002), os quais diferem por número de etapas, mas que resultam parecidos como impostação.

Com referência no modelo proposto por Coughlan e Coghlan (2002), cada ciclo de ação é formado por três fases, como apresentado nailustração 5.

Na primeira fase o objetivo é entender o contexto e os propósitos, e por isso são buscados: todos os elementos e forças presentes no contexto e no ambiente, informações que permitam entender se a PA é a metodologia apropriada para o caso em estudo, e quais contribuições ao conhecimento são esperadas.

A segunda fase é especifica para cada ciclo de PA e composta pelos seguintes seis estágios:

- Coleta de dados. É feita segundo a tipologia de dados (dados "duros" ou "moles") e pode ser realizada formal ou informalmente. A geração de dados chega através do envolvimento ativo no processo organizacional do dia-dia a respeito do projeto de 
PA. O comportamento é uma importante fonte de dados por permitir a observação da dinâmica dos grupos enquanto trabalham.

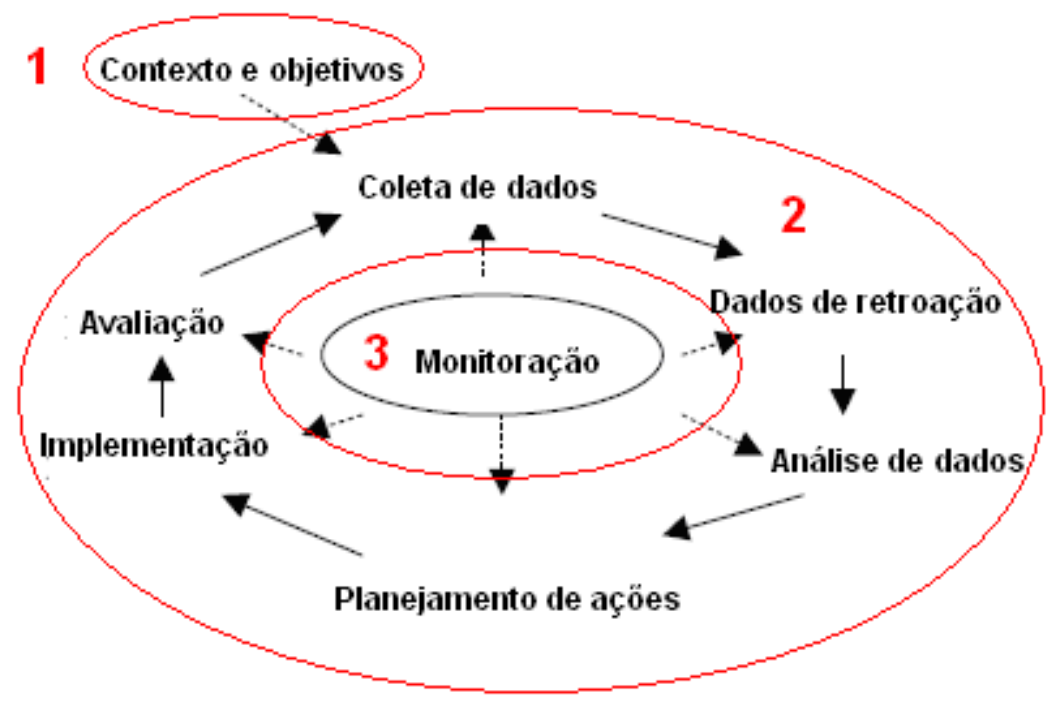

llustração 5 - Circulo de Pesquisa Ação.

Fonte: Adaptado de Coughlan e Coghlan (2002).

- Dados de retroalimentação. O pesquisador coleta os dados e depois alimenta o sistema do cliente, com o objetivo de torná-los disponíveis para a análise.

- Análise dos dados. Precisa ser realizada de modo colaborativo, baseando-se na suposição que os clientes conhecem melhor a organização, mas que precisam ser direcionados ao propósito da pesquisa.

- Planejamento da ação. É uma atividade feita em conjunto entre a diretoria e o grupo de PA.

- Implementação. O cliente programa as ações planejadas, ou seja, tenta introduzir as mudanças desejadas.

- Avaliação. Esta fase permite a reflexão sobre os resultados da ação permitindo que o próximo ciclo de PA possa se beneficiar da experiência do ciclo precedente. A avaliação é a chave para a aprendizagem.

A terceira fase é de monitoração. Esta acontece ao longo de todo o ciclo e permite a aprendizagem contínua. Nesta fase, enquanto o grupo de PA da organização se focaliza nos resultados práticos, os pesquisadores monitoram também o processo de aprendizagem, indagando através de interrogações. Estas, utilizadas também na segunda fase, como proposto da Schein (1999), podem ser de três tipos: 
- Indagações puras, buscando entender o que está acontecendo, têm que ser avaliadas escutando cuidadosamente e imparcialmente.

- Indagações para obter um diagnóstico exploratório, que pesquisa como a situação é analisada pelos outros atores;

- Indagações de confronto, aonde o pesquisador, compartilhando as próprias idéias, desafia os outros a pensarem sob novas perspectivas.

O aprendizado na ação é fundamentado no processo de reflexão e inquisição, e pode ser focalizado no exterior, sobre a organização, ou interiormente, no pesquisador. Para a ergonomia, refletir internamente sobre a própria atividade de pesquisa é de suma importância para o sucesso do projeto. Similarmente na PA a ação é a chave para a aprendizagem, pois permite ao pesquisador desenvolver a capacidade de descobrir e tornar explícito a si mesmo o que ele planeja, descobre e realiza na prática. Como explicado por Éden e Huxham (1996) a PA pode gerar teorias emergentes e de tipo incremental a partir do conceito de experiências particulares.

Na fase de monitoramento, o pesquisador utilizará um jornal de pesquisa. Este será um mecanismo significativo para desenvolver habilidades reflexivas por permitir integrar informações e experiências.

\section{2 - Levantamento de dados e entrevistas}

A busca de informações e de conhecimentos em todos os níveis da organização foi possibilitada através do apoio em técnicas típicas da ergonomia de tipo francófona.

Podem-se agrupar tais técnicas em técnicas objetivas e técnicas subjetivas (CHAPANIS, 1997):

- As técnicas objetivas ou diretas são constituídas de técnicas que impõem uma etapa importante no tratamento dos dados. Consistem no registro das atividades durante um longo período. As principais são as observações assistidas, direção do olhar, comunicações, tipologias de posturas e estudo de traços.

- Técnicas subjetivas ou indiretas são aquelas que tratam do discurso do trabalhador, e são constituídas normalmente de questionários, tabelas de avaliação 
ou entrevistas. Deve-se considerar ainda que essas técnicas são aplicadas segundo um plano pré-estabelecido de intervenção em campo, com um dimensionamento da amostra a ser considerado em função dos problemas abordados.

A ergonomia utiliza métodos e técnicas científicas para observar o trabalho humano, com o objetivo de apreender a complexidade do trabalho, e de decompor as atividades em indicadores observáveis, como a postura, as ações, a comunicação, a exploração visual e o deslocamento. Na seguinte pesquisa, por atuar em um nível mais estratégico, não se focalizou exclusivamente na observação do trabalho: utilizados muitas vezes na fase de levantamento de dados ou na fase de avaliação, tais métodos e técnicas foram úteis para uma função exploratória com o objetivo de entender os processos.

As principais ferramentas utilizadas nas fases de PA foram tanto de tipo objetivo, como as observações diretas, como de tipo subjetivo, através de entrevistas abertas e entrevistas semi-estruturadas. No presente trabalho, porém, grande espaço será dado às informações coletadas através entrevistas, em particular aquelas semiestruturadas e abertas.

Segundo Kvale (2007) a entrevista é uma conversação cuja finalidade e estrutura são definidas pelo entrevistador e uma interação profissional que vai além da troca espontânea de conversas diárias, finalizada a aquisição de conhecimento através da escuta e formulação de perguntas atentas. Baseando-se em Harrison (2004) as entrevistas apresentam várias desvantagens, entre as quais a dificuldade na administração de uma grande amostra, dificuldades na fase de análise devido as respostas á perguntas abertas e da diminuição do rigor (sendo que é possível modificar a entrevista para se adequar aos entrevistados). Tendo em consideração tais limitações, as entrevistas foram definidas como ferramentas base da pesquisa, principalmente pelas vantagens que podem oferecer. Ainda segundo Harrison (2004) as entrevistas são uma ferramenta útil por poderem cobrir muitos tópicos, construir confiança, permitir flexibilidade na modificação das perguntas antes e durante as entrevistas, poderem construir verdades, coletar dados bem detalhados e permitir o entendimento das percepções e do ponto dos interlocutores. Outra vantagem das entrevistas, segundo Bickman e Rog (2009), é a possibilidade de desenvolver relacionamentos com interlocutores da organização e aprender sobre áreas críticas, que não seriam acessíveis com questionários padrão. Existem varias sugestões de 
como realizar entrevistas na literatura. De acordo com Creswell (2007), ela é composta por três fases: a preparação da entrevista, a construção efetiva das questões de pesquisa e a implementação das entrevistas.

A preparação da entrevista é um estágio muito importante, permitindo planejá-la e construí-la coerentemente com os objetivos iniciais da pesquisa. Creswell (2007) discute a importância da escolha dos participantes, os quais devem ser qualificados ao fim da entrevista, mas também disponíveis a compartilhar as informações. Nesta fase é executado também o teste piloto, o qual permite identificar falhas e formular novas revisões antes da implementação do estudo (KVALE, 2007). Na segunda fase é crucial que as perguntas consigam extrair o maior número de informações da experiência e dos conhecimentos dos entrevistados. McNamara (2010) sugeriu algumas recomendações neste estágio: o estilo das perguntas deve ser aberto permitindo aos entrevistados responder com a própria terminologia, as perguntas devem ser as mais neutras possíveis, feitas uma de cada vez e formuladas com clareza, tomando grande cuidado com perguntas do tipo "porquê". Creswell (2007) sugeriu que se fosse flexível na formulação e construção das perguntas, sendo que os entrevistados podem não responder à questão solicitada, mas sim a outra presente mais tarde na entrevista. Para minimizar tal acontecimento o pesquisador deve construir as questões de maneira que os participantes possam responder bem direcionados ao que é perguntado. Juntamente o entrevistador deve ter prontas algumas questões de acompanhamento, para conseguir respostas bem detalhadas.

A implementação da entrevista é uma fase crítica, sendo feita em tempo real. Para tal fim existem algumas recomendações, seja na fase de inicialização como na fase de desenvolvimento da pesquisa. No estágio de preparação da entrevista McNamara (2010) sugere oito "cuidados": escolher um lugar adequado com pouca distração, esclarecer a finalidade da entrevista; discutir sobre os termos de confidencialidade, explicar o formato da entrevista; indicar a duração média da entrevista, indicar como entrar em contato com o entrevistador mais tarde, em caso de necessidade; perguntar se o entrevistado tem alguma dúvida antes de começar a entrevista; e não contar com a própria memória para decorar as respostas. McNamara (2010) apresenta também algumas recomendações para a fase de execução do processo de entrevista, ou seja: verificar ocasionalmente se o gravador (se utilizado) está funcionando, introduzir uma pergunta de cada vez; manter uma 
postura mais neutra possível, encorajar respostas ocasionais (com acenos de cabeça, "Uh huh", etc); ter cuidado com a aparência quando tomar nota (que seja neutra para não influenciar respostas futuras); proporcionar a transição entre os tópicos principais; não perder o controle da entrevista (por exemplo, por questões de tempo ou até mesmo se o entrevistado começa a fazer perguntas ao entrevistador). Além destas, Oliveira (2005) adicionou que o entrevistador não pode interferir nas respostas do entrevistado limitando-se a ouvir e gravar; na fase de preparação da entrevista prática é recomendado conhecer o lugar e as pessoas a serem entrevistadas, fazendo um contato prévio; e ainda aconselha-se utilizar o mesmo padrão de tópicos para cada pessoa que se pretende entrevistar.

Grande atenção também deve ser dada à interpretação dos dados, os quais devem ser agrupados segundo seções e grupos de informações, ou temáticas (CRESWELL, 2007). Estas contêm frases, expressões ou idéias em comum entre os participantes da pesquisa (KVALE, 2007). Existem vários tipos de entrevistas, mas para o atual trabalho de mestrado foram utilizados dois tipos; a entrevista aberta e a entrevista semi-estruturada.

Nas entrevistas abertas, o conteúdo das questões não é fixo e pode variar de indivíduo para indivíduo, são propostos apenas temas gerais para serem abordados (CORBETTA, 1999). O entrevistador tem a tarefa de apresentar os temas da entrevista e permitir que o entrevistado fale sobre os seus pontos de vista, deixando a ele a iniciativa da conversa. $O$ entrevistador pode direcionar a conversa, saindo de temas poucos importantes, ou encorajando assuntos considerados dignos de atenção para a investigação. Desta forma, dado um tema geral, cada entrevista torna-se um conteúdo exclusivo, em tempos de duração e tipo de relação estabelecida entre o entrevistador e o entrevistado.

A entrevista semi-estruturada é uma forma particular de conduzir uma entrevista e, portanto, um instrumento de coleta de dados. Neste tipo de entrevista, o entrevistador possui um roteiro com os argumentos e as perguntas guias a serem tratadas durante a entrevista (CORBETTA, 1999). Embora esta seja uma direção fixa e comum a todos, a realização das entrevistas podem ser alteradas com base nas respostas dadas pelo entrevistado e com base na situação individual. O roteiro é uma espécie de fronteira em que o entrevistado tem a liberdade de movimento que Ihe permite tratar todos os assuntos necessários ao fim da pesquisa. Por isso é 
muito importante que seja bem claro o real propósito da pesquisa e os temas a serem enfrentados. Diferentemente da entrevista aberta, a fase de tratamento dos dados fica mais simples, possibilitando a comparação das respostas entre os entrevistados.

\section{3 - Método: pesquisa ação no Hospital Universitário da USP}

Um ponto crítico a ser levado em consideração no começo de uma PA é o vinculo temporal, sendo este tipo de pesquisa muito demorada (COUGHLAN e COGHLAN, 2002). A escolha do Hospital Universitário da Universidade de São Paulo (HU-USP) para a aplicação de uma PA foi natural. Além de responder aos requisitos descritos anteriormente de ter a presença de problemas reais de interesse de pesquisa e de conseguir um contato chave, a escolha do HU-USP permitiu também superar o limite do tempo. A precedente experiência e trabalho acadêmico na instituição no ano de 2006 permitiram ao pesquisador ter um conhecimento prévio da situação e da organização, ajudando-o a começar a pesquisa mais rapidamente.

A principal pessoa de referência no HU-USP para iniciar tal pesquisa foi uma das assessoras da Superintendência. Isso ajudou particularmente a pesquisa, pois a sua posição na hierarquia da organização facilitou consideravelmente o trabalho dos pesquisadores, sobretudo por ter uma ótima mobilidade no interior da empresa, mas também por conseguir os contatos necessários de vez em vez, em todas as áreas do hospital. Além disso, sendo ela medica e tendo experimentado as condições de trabalho da profissão, é mostrado um grandíssimo interesse em assuntos de qualidade de trabalho com o fim de implementar melhorias no hospital universitário.

Além da assessora da Superintendência, as pessoas do HU-USP envolvidas no projeto variaram de acordo com cada fase da pesquisa, chegando de diferentes áreas e de diferentes níveis hierárquicos. 


\subsection{1 - Pesquisadores envolvidos}

A pesquisa no HU-USP é possibilitada pelas ligações entre a Escola Politécnica da USP (em particular do departamento de Engenharia de Produção) e o hospital. Para cada projeto que já aconteceu foi criado um grupo ad hoc, e da mesma maneira, para o presente projeto, foi criado um outro grupo de pesquisadores. Este foi instituído no começo de 2009 por estudantes com o interesse em comum por assuntos de ergonomia, também se com diferentes vertentes. Os participantes foram dois estudantes de graduação e dois estudantes de mestrado.

As principais habilidades requeridas dos pesquisadores são de diagnose e intervenção em relação aos problemas presentes nas organizações. Além disso, os pesquisadores precisam gerar dados assim que algumas das competências essenciais encontram-se na área de autoconsciência e sensitividade. Ter conhecimentos na área do comportamento organizacional, no qual basearão suas observações é fundamental. É importante que os pesquisadores sejam treinados e educados em desenvolver habilidades de indagação interpessoais e de ajuda, assim se o pesquisador é ainda inexperiente torna-se interessante o acompanhamento de outro pesquisador mais experiente.

Por este motivo, além dos quatro estudantes o grupo de pesquisa é composto também por um professor da área de ergonomia com a tarefa de auxiliar e aconselhar. Todo o grupo encontra-se diretamente envolvido na implementação do comitê de melhoria (CM), enquanto cada um tem uma sub-pesquisa própria.

\subsection{2 - Ciclos do projeto de pesquisa ação}

O primeiro período de concepção do projeto de PA levou o autor à compreensão e a seleção dos principais problemas para os quais serão buscadas soluções. Este foi um processo bem complexo, exigindo que ele buscasse junto à assessora da Superintendência quais eram as oportunidades de pesquisa mais urgentes na organização e também procurasse junto ao professor orientador quais as possibilidades de intervenção segundo a própria linha de pesquisa. 
A fase de planejamento permitiu definir dois ciclos principais de PA:

- Análise e crítica do trajeto de ações ergonômicas desenvolvidas na instituição em estudo, e análise do grau de disseminação da ergonomia;

- Envolvimento dos trabalhadores em um processo de melhoria na organização num nível estratégico (aplicação na seção das compras);

A primeira fase de ambos os ciclos de PA foi desenvolvida logo na entrada no projeto através do contato inicial com as pessoas do HU-USP (sobretudo com a assessora da Superintendência) e as primeiras reuniões.

A seguir são descritos ambos os ciclos de PA desenvolvidos no projeto prático na HU-USP, lembrando que nem todos os dados levantados através estes ciclos serão apresentados nos resultados e na discussão dos mesmos.

No caso do autor, e como antecipado na introdução, a participação do autor foi num dos eixos do CM.

Analise e critica ao trajeto de ações ergonômicas desenvolvidas na instituição em estudo, e analise do grau de disseminação da ergonomia

Como já apresentado, no HU-USP atua em um CM. Este foi criado em 2008 com o objetivo principal de introduzir eixos de ação para implementar melhorias na organização. Com a entrada do autor em tal proposta, início de 2009, decidiu-se dar continuidade a este meio organizacional para conseguir aplicar os eixos propostos em toda a organização. $O$ foco do autor foi acompanhar as reuniões com o objetivo de identificar pontos fortes e fracos de tal meio, considerando-o como a continuação de todo um processo de melhoria ergonômica começado em 2000 na instituição em estudo.

Este ciclo de PA foi desenvolvido principalmente através do prévio estudo de AET no SAME, da participação no $\mathrm{CM}$ e do contato com os sujeitos participantes que foram em contato com as ações ergonômicas desenvolvidas no HU-USP até o instante. Sem entrar em detalhe sobre todas as fases da PA descritas por Coughlan e Coghlan (2002) deste ciclo, a presente dissertação encentrará a atenção sobre a fase de avaliação do conjunto de todas as ações desenvolvidas no HU-USP (e não exclusivamente do comitê). Esta, além do levantamento participativo de 
informações, foi possibilitada da aplicação de entrevistas semi estruturadas a todos os gestores do hospital, aos participantes do CM, e aos participantes do Grupo de Treinamento e Capacitação - GTC (os últimos dois grupos vistos como participantes das principais ações ergonômicas desenvolvidas no nível mais estratégico na organização). Além destas entrevistas semi-estruturadas, duas entrevistas abertas, uma com o superintendente e uma com a assessora investida de seguir e coordenar os projetos ergonômicos pelo hospital, permitiram ao pesquisador ter visão mais completa sobre toda a intervenção ergonômica neste enfoque.

No trabalho aqui descrito, a atenção foi dedicada ao estudo do comportamento dos atores-chave envolvidos diretamente ou indiretamente nas principais ações ergonômicas desenvolvidas até o instante, entendendo a relação entre o grau de envolvimento deles, ligado ao rolo institucional, com o grau de sucesso de tais ações.

Envolvimento dos trabalhadores em um processo de melhoria da organização no nível estratégico (aplicação na seção das compras)

Este ciclo de PA teve origem na proposta de ajudar diretamente na resolução de um dos quatro eixos de ação a serem analisados no CM, ou seja, a aquisição de materiais, equipamento, sistemas de informação e serviços. Nesta área estão presentes muitas queixas por parte dos operadores, sobretudo pela insatisfação na compra de material que auxilia o trabalho diário. Sendo de interesse estratégico a melhoria desta área, o autor quis testar a aplicação do próprio estudo provocando um processo de mudança que possa envolver diretamente os trabalhadores no instante da compra, sobretudo de equipamentos.

A equipe de pesquisa deste ciclo de PA é composta pelo autor do presente projeto de pesquisa, de uma assessora da Superintendência (diferente daquela de contato), do chefe da seção das compras do HU-USP, do chefe da seção dos materiais da enfermagem e o chefe da fisioterapia.

Também neste caso, objetivo da presente dissertação, não é descrever as fases de PA e a solução prática, mas ter um recorte sobre a temática do envolvimento dos trabalhadores em processo de melhoria da organização no nível estratégico. A discussão será assim centralizada na apresentação da problemática e na fase da 
coleta de dados (entrevistas semi-estruturadas sobre a temática das compras de todos os gestores do hospital) aonde são apresentados os resultados divididos em tipologia de entrevistados / grau de emancipação.

\subsection{3 - Entrevistas semi-estruturadas no HU-USP}

As entrevistas e as observações abertas constituíram um bom meio para a coleta de informações nas duas fases da PA, porém para a finalidade da dissertação foi fundamental a introdução de entrevistas semi-estruturadas.

As entrevistas semi-estruturadas foram direcionadas a três diferentes grupos de atores da organização:

- Todos os gestores do hospital. Por causa da falta de homogeneidade em termos de departamento de origem, de nível na hierarquia organizacional, e/ou do grau de conhecimento sobre os objetos da entrevista; foi decidido desenvolver as entrevistas sobre o inteiro universo de tal grupo, assim que tal entrevista foi desenvolvida a 46 entrevistados. Estes provinham do departamento da Enfermagem (quatro chefes das quatro macro áreas e dezessete sub-chefes), do departamento Medico (oito chefes de área), do serviço de arquivo medico e estatístico - SAME (a chefe do serviço e três sub-chefes), do serviço de Manutenção e Engenharia Hospitalar (duas chefes) e outros onze chefes diretos das áreas remanentes. O objetivo de tal entrevista era entender as dificuldades que a instituição apresenta e o envolvimento em tais assuntos das pessoas chave da organização. Uma segunda parte foi dedicada ao assunto das compras (tópico desenvolvido no segundo ciclo de PA) buscando as problemáticas e relacionando as mesmas ao grau de envolvimento do entrevistado (a estrutura e as perguntas de tal entrevista podem ser conferidas no anexo B).

- Os participantes do hospital no CM por pelo menos três reuniões no biênio 20092010. Desenvolvido com 6 entrevistados, o objetivo era obter os feedbacks sobre o trabalho desenvolvido no $\mathrm{CM}$, focalizando a atenção sobre as percepções de envolvimento dos vários atores de tal meio organizacional (a estrutura e as perguntas de tal entrevista podem ser conferidas no anexo C) 
- Quem participou do GTC. Desenvolvido com todos os 19 participantes do grupo, o objetivo de tal entrevista foi a obtenção dos feedbacks conclusivos sobre as impressões pessoais durante e depois da participação do grupo, focalizando sobre como o entrevistado passou a fazer parte da iniciativa, se ampliou os próprios conhecimentos e se consegui aplicá-los, o apoio da organização e o grau de envolvimento nos assuntos objetos do curso. (a estrutura e as perguntas de tal entrevista podem ser conferidas no anexo D)

As entrevistas foram de tipo pessoal e planejadas para serem desenvolvidas em uma hora. Embora tal propósito, a duração das mesmas foi variável entre os trinta minutos e uma hora e quinze minutos dependendo dos entrevistados. Na fase de preparação, construção e implementação das entrevistas foram consideradas e seguidas todas as sugestões buscadas na literatura e explicadas antecedentemente. $\mathrm{Na}$ fase de desenvolvimento da entrevista, estas eram entregues no dia sucessivo aos entrevistados para possibilitar uma rápida validação. 


\section{5 - RESULTADOS}

\section{1 - Apresentação geral da empresa}

O Hospital Universitário da Universidade de São Paulo (HU-USP) é um hospital com fins de pesquisa localizado no campus da Cidade Universitária de São Paulo, ocupando $36.000 \mathrm{~m}^{2}$ de área edificada. Construído em 1981 a partir de um projeto arquitetônico de hospital universitário alemão, o HU-USP depende economicamente do fomento da Universidade USP e do Estado de São Paulo, tendo por isso algumas limitações financeiras, sobretudo da primeira fonte. Diferentemente dos hospitais tradicionais, por ser universitário, além de ter metas de excelência na assistência médica, focaliza a sua atividade também em propiciar altos níveis de pesquisa e de ensino.

A sua estrutura organizacional é muito parecida com a dos outros hospitais universitários brasileiros e, por não ter objetivos empresariais como lucro e crescimento econômico, a estrutura organizacional não inovou muito, ficando estritamente ligada àquela da universidade. $O$ cargo de maior importância, e de conseqüência de maior prestígio do hospital, é o de superintendente, o qual participa do conselho de administração da universidade USP e depende diretamente do reitor da Universidade (llustração 6). A troca do cargo de superintendente é de decisão especifica da reitoria da universidade, e teoricamente pode ocorrer a qualquer instante. Em geral, a cada eleição do novo reitor da universidade segue a nomeação de um novo superintendente. Entrando em detalhes, no ano da entrada do novo reitor é feita uma votação no conselho de diretores do HU-USP para entregar ao reitor uma lista com três nomes com maior votação para ele escolher o novo superintendente. Como regra geral normalmente é escolhido aquele que recebeu mais votos, mas nem sempre isso acontece, sendo este um cargo de confiança. $O$ conselho de diretores é composto pelos nove diretores das nove faculdades e unidades de ensino presentes no hospital, por um representante de alunos, um representante de funcionários da USP, um representante da população da região, além do superintendente em cargo. $O$ conselho pode também fazer pressão para que o reitor troque o superintendente a qualquer instante, se existirem divergências, 
antes do término natural do cargo. Em janeiro de 2011 entrou no HU-USP um novo superintendente, conseqüente da troca de reitor da USP em 2010.

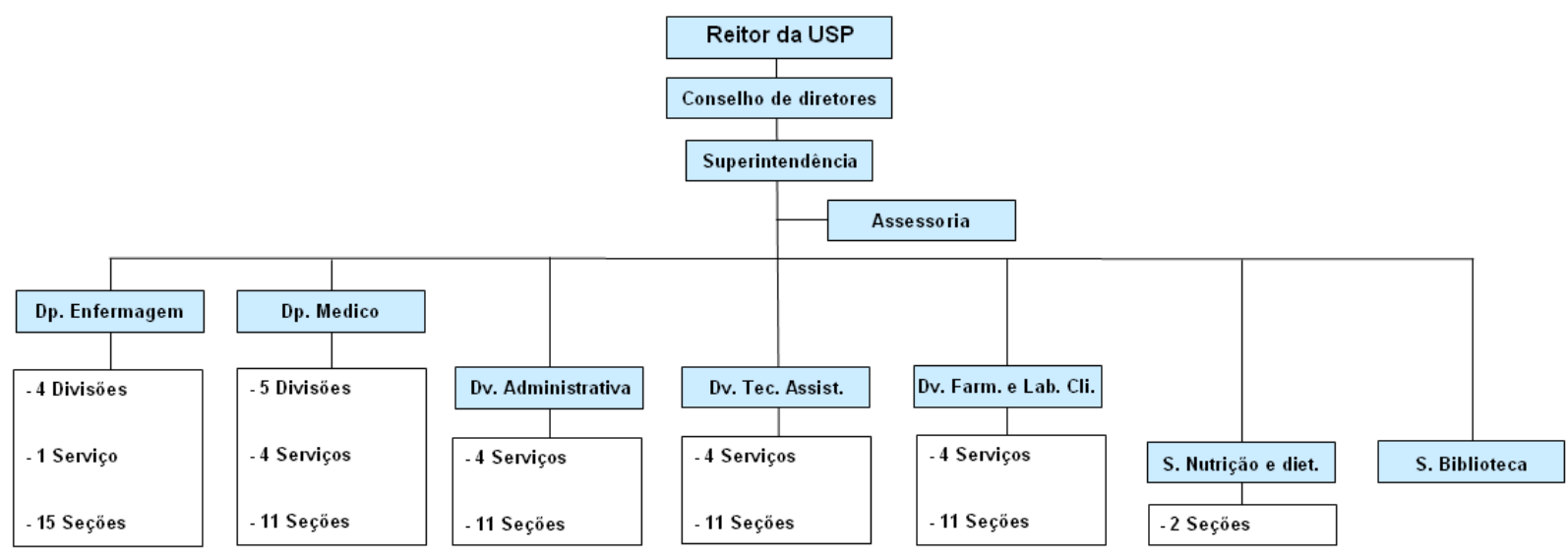

llustração 6 - Organograma do HU-USP.

Fonte: Elaboração própria a partir dos dados de pesquisa de campo.

No organograma do HU-USP e abaixo da Superintendência (numa posição de staff), se posiciona a assessoria, composta por cinco a seis cargos de indicação, sendo que estes são escolhidos diretamente pelo superintendente. Este os nomeia baseado na percepção dos pontos que não consegue alcançar na sua gestão pessoal, delegando assim indiretamente o próprio poder. Mesmo assim as decisões finais são exclusivas do superintendente. O cargo de assessor não pode ser considerado estável, podendo ser removido ou introduzido em qualquer instante pelo superintendente.

\section{2 - Questão da saúde dos trabalhadores no HU-USP}

Como apresentado na fase de formulação da problemática, no início da presente dissertação, os trabalhadores do atendimento hospitalar do estado de São Paulo tiveram a maior quantidade de acidentes comparados a todos os outros trabalhadores de outras áreas econômicas. O HU-USP não é exceção e apresenta muitos problemas internos devido ao alto número de pessoas que trabalham com restrições e de afastamentos a longo prazo causados por doenças ocupacionais. 
No anexo E são apresentados algum dados levantados através de entrevistas com os gestores. Além da área e o serviço de atuação dos entrevistados, foi levantado o número de funcionários ativos (excluindo os terceirizados), o número de funcionários com restrições no trabalho, e o número de afastados a longo prazo por doenças ocupacionais contraídas no trabalho no instante da entrevista. O resultado final nos mostra a dimensão do problema no $\mathrm{HU}$, aonde mais de $10 \%$ dos funcionários está trabalhando com restrições recomendadas pelo SESMT (de diferentes naturezas) e $1,5 \%$ de pessoas afastadas a longo prazo por doenças relacionadas ao trabalho.

Para simplificar a análise os dados foram divididos em quatro grupos de áreas (tabela 2): o grande bloco de enfermagem, o bloco dos médicos, os serviços que tiveram historicamente maiores problemas com a saúde dos trabalhadores no HUUSP (SAME, Higienização Especializada, Nutrição e dietética) e os demais. A divisão feita nas quatro categorias ajuda entender como problemas sobre a saúde no trabalho são igados a áreas (e atividades) bem definidas. Levantar o bloco de serviços que tiveram maiores problemas quer dizer encontrar os lugares aonde as condições de trabalho fazem adoecer com maior facilidade. Estes são: a enfermagem em geral, o bloco do SAME, Higienização hospitalar e Nutrição e dietética, e o serviço de informática, lugares aonde existem tarefas repetitivas, manuais e com baixa variação na rotina.

\begin{tabular}{|l|c|c|c|c|c|}
\hline \multicolumn{1}{|c|}{ Área } & $\begin{array}{c}\mathrm{N} . \\
\text { Funcionários }\end{array}$ & $\begin{array}{c}\text { Com } \\
\text { restrições }\end{array}$ & $\begin{array}{c}\% \\
\text { Restr. }\end{array}$ & $\begin{array}{c}\text { Afastamentos } \\
\text { a L.P. }\end{array}$ & $\begin{array}{c}\% \\
\text { Afast. }\end{array}$ \\
\hline Enfermagem & $775\left(685^{*}\right)$ & $81(8$ psiq. $)$ & $11,8 \%^{*}$ & $15(6$ psiq. $)$ & $1,9 \%$ \\
\hline Medico & 274 & 0 & $0,0 \%$ & 0 & $0,0 \%$ \\
\hline SAME, Hig. e Nutri. & 291 & $60(1$ psiq. $)$ & $20,6 \%$ & 8 & $2,7 \%$ \\
\hline OUTROS & $264\left(176^{*}\right)$ & 6 & $3,4 \% *$ & 1 & $0,4 \%$ \\
\hline TOTAL & $1604\left(1426^{*}\right)$ & $147^{*}$ & $10,3 \% *$ & 24 & $1,5 \%$ \\
\hline
\end{tabular}

Tabela 2 - Dados sobre funcionários com restrições e afastamentos a longo prazo no HU-USP.

* Nem todos os gestores responderam sobre o número de funcionários com restrições, de modo que as porcentagens foram calculadas exclusivamente sobre quem respondeu.

Fonte: Elaboração própria a partir dos dados de pesquisa de campo.

Oposta é a situação dos médicos. Foi explicado nas entrevistas por algum deles que não existe nenhum profissional com restrições ou com afastamento de longo prazo, já que geralmente executam atividades muito variadas. Acredita-se que existam 
médicos com doenças ocupacionais, mas pela própria posição profissional e pelas suas responsabilidades, não as reconhecem.

Além da natureza de algumas atividades, existem algumas agravantes no HU-USP:

- A estreita dependência econômica da universidade USP leva a uma política de contratação que minimize quanto possível o número de novos funcionários. Em uma situação de poucos funcionários, em comparação às necessidades reais, a situação piora ulteriormente com a presença de pessoas doentes e afastadas, necessitando portanto que haja uma intensificação do trabalho para os restantes.

- A população de trabalhadores do HU-USP está ficando idosa (ilustração 7) com as relativas conseqüências. Em alguns cargos existe uma rotatividade de funcionários quase nula.

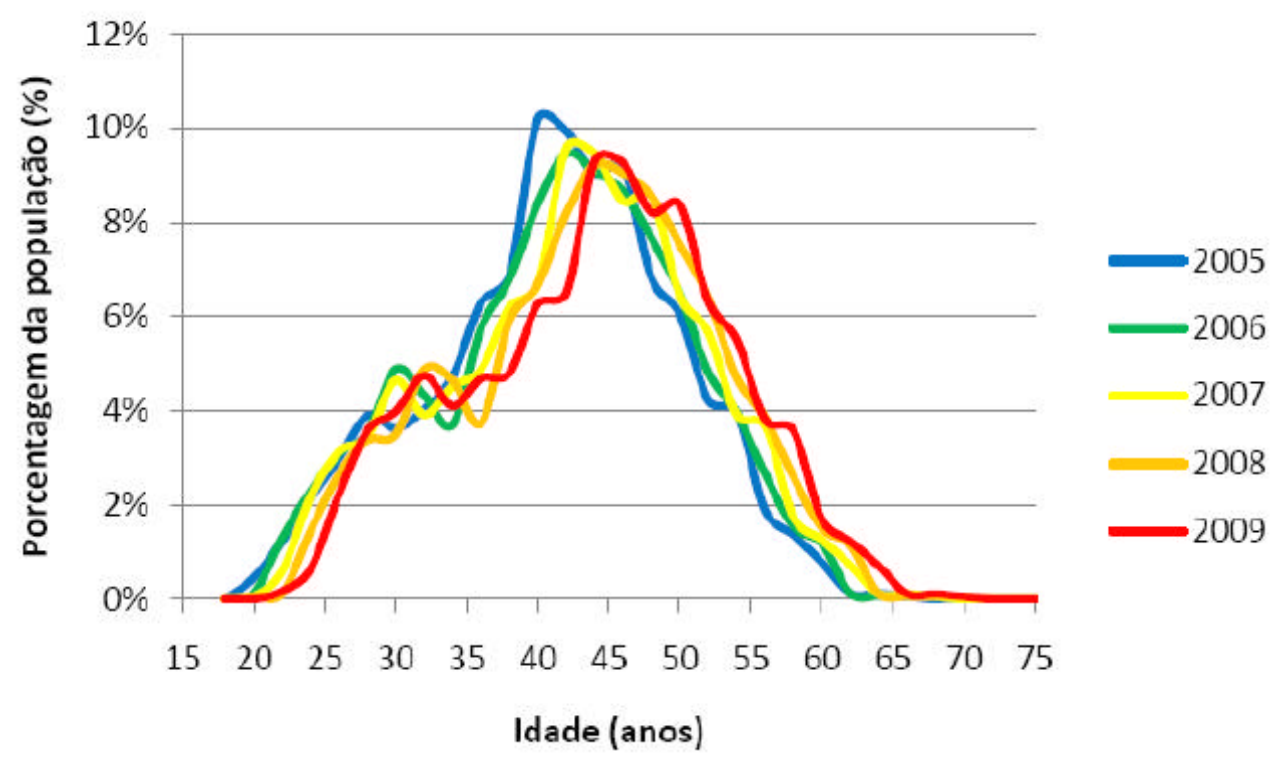

Ilustração 7 - Distribuição etária de 2005 a 2009.

Fonte: Extraído de Mitsuishi (2009).

- A estrutura existente não é adequada ao tamanho de trabalho que é desenvolvido nos últimos anos. O hospital foi construído 28 anos atrás, e desde esta época ocorreu um aumento relevante no número de pacientes que recorre ao hospital, sendo que apenas poucos dos processos já foram modernizados ou adaptados às novas exigências. Além disso, o fato de ter sido construído a partir de um projeto arquitetônico alemão introduz também problemáticas estruturais (ex. tomadas da corrente elétrica não utilizáveis, falta de luminosidade, etc). 
Tudo isso contribuiu para que a Superintendência percebesse a gravidade da situação e que apoiasse ações para prevenir doenças ocupacionais.

\section{3 - Análise e crítica do trajeto de ações ergonômicas desenvolvidas na instituição em estudo e análise do grau de disseminação da ergonomia - avaliação}

Como antecipado no capitulo da metodologia, através do primeiro ciclo de PA e focalizando na fase de avaliação do mesmo, o objetivo foi analisar o conjunto de todas as ações ergonômicas desenvolvidas no HU-USP em relação ao grau de envolvimento dos atores, ao papel da direção da organização e aos pontos de sucesso e insucesso de tal iniciativa. Para tal, além da participação ativa em algumas das propostas ergonômicas presentes no HU-USP, foram desenvolvidas entrevistas com vários atores que tiveram contato com tais propostas.

A seguir, são apresentados os resultados seja de observações que de entrevistas, divididos por tópicos. Pela sua importância na dissertação, o CM foi apresentado primeiro partindo dos resultados práticos alcançados e sucessivamente através da análise das entrevistas. A seguir o mesmo foi feito com o GTC. Como terceiro tópico, foi apresentado o conjunto de resultados das entrevistas aos gestores (buscando entender o grau de disseminação dos conceitos ergonômicos entre eles). Enfim a avaliação deste ciclo de PA se conclui com a descrição da visão estratégica por parte da direção da empresa, com os depoimentos da assessora que acompanhou diretamente este projeto de ergonomia no interno do HU-USP e do superintendente.

\subsection{1 - Comitê de melhorias (CM)}

O CM permitiu aos pesquisadores experimentar se na situação especifica do HUUSP é possível ou não obter alinhamento entre as necessidades e as oportunidades que surgem no trabalho operacional e as políticas estratégicas da empresa, além de experimentar se tal meio pode se sustentar ao longo do tempo. Com tal finalidade, a postura da equipe da Escola Politécnica foi sempre de exclusivo apoio em introduzir 
conceitos ergonômicos, ajudando ativamente a alcançar os objetivos preestabelecidos. Intencionalmente, com o passar do tempo foram sempre diminuindo os casos em que a equipe da Escola Politécnica tomou a iniciativa de propor reuniões para os participantes do CM.

$\mathrm{Na}$ fase atual os resultados alcançados foram os seguintes:

- no eixo da vigilância epidemiológica foi criado um sistema informático de coleta de dados de apoio às decisões dos gerentes (número de funcionários ativos, número de funcionários com restrições e a tipologia, o sexo, idade e tempo de casa de cada funcionário). Isso foi conseguido através de reuniões do CM na fase de definição dos conteúdos, e sucessivamente na fase de criação e teste através de reuniões entre uma mestranda, a assessora responsável pelo projeto no hospital, um técnico do departamento da Informática e o chefe do Serviço Pessoal. A determinação da assessora, a ajuda ativa da mestranda, e o apoio técnico do chefe do Serviço Pessoal e do técnico da Informática foram determinantes para o sucesso de tal eixo.

- no eixo das políticas para trabalhadores com restrições e necessidades especiais pouco foi feito, embora houvesse o envolvimento direto da chefe de Fisioterapia, que após a participação do GTC passou a executar estudos de AET nas áreas mais críticas e com alto número de trabalhadores com restrições. $\mathrm{O}$ fato de tais análises não causarem mudanças estruturais (apenas pontuais), de tomar muito tempo da chefe de Fisioterapia, e dela se sentir sozinha agindo em tal eixo, fez com que tal iniciativa fosse aos poucos deixada de lado.

- no eixo de aquisição de materiais, equipamentos, sistemas de informação e serviços ocorreram algumas discussões nas reuniões do $\mathrm{CM}$, mas as ações práticas foram desenvolvidas externamente, principalmente devido à ajuda da equipe do departamento de Engenharia da Produção. O autor desenvolveu uma análise do processo de aquisições na instituição, uma entrevista com todos os chefes sobre compras e a análise do caso de compra de cadeiras; a estudante de iniciação cientifica fez um estudo de AET que promoveu a compra de novas autoclaves para higienização de mamadeiras e a máquina para envasamento automático de leite, e enfim um docente da Escola Politécnica cuidou do estudo sobre carrinhos de transporte de refeições. Acredita-se que sem a ajuda da equipe da Engenharia da Produção poucos resultados seriam alcançados. 
- no eixo da adequação das instalações também ocorreram discussões nas reuniões do $\mathrm{CM}$, e no lado prático houve avanços para que as sugestões conseqüentes aos trabalhos de AET desenvolvidos através o GTC sejam aplicadas. Um papel fundamental foi o da assessora da Superintendência responsável pelo CM do hospital, que foi elo para obter apoio da Superintendência. Embora isso, o comitê não desenvolveu papel ativo sendo que, por exemplo, não existe ainda um plano de metas para a adequação das instalações com critérios ergonômicos.

Do lado organizativo, as reuniões do CM foram diminuindo de intensidade ao longo do tempo, nas últimas ocorreram à distância de meses. Com a necessidade da assessora responsável do $\mathrm{CM}$ de trabalhar em outro local fora do HU-USP por alguns meses (abril-setembro 2010) e a sua sucessiva volta na instituição sem o cargo de assessora, as reuniões pararam de acontecer.

\subsubsection{1 - Analise das entrevistas}

Os entrevistados sobre o $\mathrm{CM}$ foram seis, todos internos ao hospital, e que participaram pelo menos de três reuniões no biênio 2009-2010 (período de atuação do pesquisador). A escolha de entrevistar quem participou a um número mínimo de reuniões foi necessária para afunilar a entrevista aos atores realmente envolvidos. Destes, duas eram assessoras da Superintendência, uma a responsável pelas ações ergonômicas no hospital e a outra a indicada pela Superintendência para substituir a antecedente a partir de abril 2010. Outros participantes foram: a diretora de um dos departamentos mais críticos para o número de afastamentos de funcionários, um chefe de serviço direto ao cuidado de trabalhadores com doenças ocupacionais, e um chefe e um técnico envolvidos no eixo da vigilância epidemiológica na construção de ferramentas informáticas. Os resultados apresentados a seguir foram divididos por assunto.

\section{Objetivos do CM}

Definido na introdução da dissertação quais eram os objetivos do CM planejado pelo grupo de pesquisa e quais as finalidades da sua construção, foi buscado entender 
quais eram os objetivos na visão dos entrevistados. A entrevista permitiu entender que metade dos entrevistados tinha uma idéia completa e compatível àquela proposta pela Escola Politécnica, a outra metade não. Um participante apresentou uma idéia muito vaga e genérica, enquanto outros dois responderam limitando o $\mathrm{CM}$ ao único objetivo de construir a ferramenta informática, sendo que eles foram chamados exclusivamente para colaborar a desenvolver tal instrumento.

\section{Parecer sobre o CM (positivo - negativo)}

Obter um parecer sobre os resultados conseguidos até o instante permite entender qual a consideração dos participantes em tal meio organizacional. Em geral, o CM foi considerado uma ferramenta muito interessante e útil. Enquanto dois entrevistados descreveram que os resultados foram totalmente positivos, um não sabia o que responder por não conhecer os objetivos reais, um afirmou não conhecer todos os resultados para podê-los avaliar completamente, e dois, mesmo indicando a positividade da proposta, enxergaram alguns limites na presença de um número de eixos excessivo que poderia causar o não aproveitamento de todo o potencial de tal meio organizacional.

\section{Visão futura do $C M$}

Esta questão permite entender a sustentabilidade no tempo do CM no olhar dos participantes. Em geral as perspectivas futuras do CM para os entrevistados são negativas. Percebeu-se que os entrevistados encontraram algumas dificuldades organizativas, e com o tempo o comitê parou de atuar. Mesmo assim, segundo eles, o CM teria futuro se fizesse parte das futuras políticas estratégicas da organização, na entrada do novo superintendente. Permanece a sensação que nas condições organizativas atuais não existem perspectivas reais de atuação.

Grau de envolvimento da equipe do departamento de Engenharia da Produção até o momento atual

A importância desta resposta reside no fato de entender a necessidade de apoio externo por parte de profissionais da área de ergonomia. A resposta foi unânime e 
foi identificado como totalmente positivo o envolvimento de tal equipe. Os entrevistados reconhecem que sem a mesma teriam bem poucos fundamentos teóricos para introduzir uma ação bem estruturada. Além disso, a equipe da Escola Politécnica tem um olhar externo sobre a organização, e por isso menos viciado e mais objetivo.

Grau de envolvimento dos outros participantes do CM e da instituição até o instante

Esta questão permite entender qual foi o comprometimento percebido pelos entrevistados sobre os colegas do CM e da instituição (como diretoria, não incluindo as assessoras participantes do $\mathrm{CM}$ ) sendo que como foi confirmado pelos entrevistados, agir dentro de um grupo comprometido é um fator importante que impacta diretamente no grau de motivação e de participação dos mesmos. Resumindo as respostas, o envolvimento percebido dos outros participantes do CM foi em geral baixo. Ativo somente se os assuntos fossem relacionados a interesses pessoais dos mesmos. Com isso, houve concordância nas respostas indicando apenas duas pessoas como as mais ativas e participantes.

$\mathrm{Na}$ resposta sobre o grau de envolvimento da instituição, duas pessoas não exprimiram parecer algum, reconhecendo ter uma visão limitada, enquanto todos os outros foram concordes em afirmar que o apoio da instituição foi limitado pelo fato do CM não entrar nos planos estratégicos da Superintendência.

\section{Grau de envolvimento pessoal no CM até o instante e no futuro}

A pergunta sobre o grau de envolvimento pessoal no $\mathrm{CM}$ teve a intenção de entender a visão de cada componente sobre a importância dada a este meio organizacional e a contribuição que ele mesmo quer entregar. Percebeu-se diferentes níveis de envolvimento entre os entrevistados. Entrando em detalhes, dois deles executaram exclusivamente as tarefas para as quais foram introduzidos ao CM. Embora os dois não se sintam parte ativa, um se sente engajado porque gosta do assunto e seria totalmente disponível para ajudar futuramente, enquanto o outro se limita a "realizar o trabalho que foi definido", e no futuro participaria apenas se fosse requisitado o seu conhecimento técnico. Dois entrevistados tiveram uma postura proativa, uma deu uma contribuição total, coordenando e possibilitando o 
maior sucesso possível dentro do hospital para que esta ação ergonômica acontecesse, e outro, o qual além de ter participação ativa nas reuniões possibilitou a continuação de ações práticas fora do CM, mesmo estas não estando previstas nas suas tarefas de trabalho. Enfim, outra pessoa teve um apoio ativo acreditando na importância de tal meio, enquanto o ultimo entrevistado não se sentiu envolvido diretamente e a sua ajuda consiste, segundo depoimento pessoal, para questões pontuais, sendo que a ergonomia não fará parte da sua rotina de trabalho e prioridades.

\section{Sugestões}

Partindo do reconhecimento da importância do assunto e do fato que o CM parou de funcionar, a principal sugestão levantada foi retomar a iniciativa, mas com maior autonomia do hospital. Isso seria possível, segundo eles, aumentando a visibilidade, sendo que nunca houve no hospital uma preocupação em comunicar sequer os resultados positivos possibilitados pela ergonomia.

Para smplificar a compreensão, com a tabela 3 foram introduzidas as respostas dadas por cada entrevistado em quatro das seis questões antecedentemente apresentadas.

\begin{tabular}{c|c|c|c|c|c|c|}
\hline & Entrev. 1 & Entrev. 2 & Entrev. 3 & Entrev. 4 & Entrev. 5 & Entrev. 6 \\
\hline Env. Pessoal & Proativo & Proativo & Ativo & Suporte & Suporte & Externo \\
\hline Objetivos & Conhecidos & Conhecidos & Geral & Limitado & Limitado & Conhecidos \\
\hline Parecer & Tot. positivo & Positivo & Positivo & Tot. positivo & Neutro & Positivo \\
\hline Visäo futura & Negativa & Negativa & Neutra & Positiva & (Sem resp.) & Neutra \\
\hline
\end{tabular}

Tabela 3 - Respostas agregadas dos participantes do comitê de melhorias.

Fonte: Elaboração própria a partir dos dados de pesquisa de campo.

Dados interessantes extraídos desta tabela:

- Os que não tinham clareza dos objetivos do CM tiveram um envolvimento pessoal exclusivamente de suporte.

- Quem teve um envolvimento pessoal proativo conhecia os objetivos (sabendo também que o CM não tinha uma importância estratégica pela organização) e foram os únicos com uma visão futura negativa. 
- Existe uma unanimidade em quem conhece os objetivos reais do CM em dar um parecer positivo sobre o $\mathrm{CM}$.

\subsection{2 - Grupo de Treinamento e Capacitação (GTC)}

A fase de criação do grupo foi delegada à instituição, vinculada ao fato que a participação fosse voluntária e que não houvesse envolvimento por parte da área médica. Com tal limitação o grupo foi formado a partir de convites que a acessória da Superintendência enviou às áreas que, mais teriam aproveitado a aplicação de conceitos ergonômicos, áreas aonde os trabalhadores têm maior facilidade de contrair doenças ocupacionais (por exemplo, no Serviço de Arquivo Médico Estatístico - SAME, na Enfermagem, no Departamento de Nutrição, no Departamento de Higienização Especializada e no Almoxarifado), ou por trabalhar em áreas que cuidam da saúde ou da ergonomia de outros trabalhadores (por exemplo Fisioterapia, Terapia Ocupacional, Engenharia Hospitalar e SESMT).

O GTC foi composto por 19 profissionais provenientes de diferentes áreas do hospital e com diferentes cargos. Como apresentado na tabela 4, estes podem ser agrupados em quatro tipologias principais de profissionais: quem trabalha em áreas de cuidado direto da saúde do trabalhador (dois terapeutas ocupacionais e três fisiologistas), quem trabalha em áreas estratégicas para o cuidado da saúde do trabalhador (um chefe do SESMT e um chefe da Manutenção e Engenharia Hospitalar), quem trabalha na área operacional com presença de problemas de saúde (quatro enfermeiras, um trabalhador do SAME e um do almoxarifado) e enfim quem trabalha como chefe ou coordenador em áreas criticas (cinco da enfermagem e uma da farmácia).

\begin{tabular}{|c|l|c|}
\hline Cod. & \multicolumn{1}{|c|}{ Tipo de trabalhador } & Quantidade \\
\hline E & Em áreas de cuidado direto a saúde do trabalhador & 5 \\
\hline F & Em áreas estratégicas para o cuidado da saúde do trabalhador & 2 \\
\hline G & Operativos em áreas criticas, & 6 \\
\hline H & Em áreas criticas, com poderes de chefia ou de coordenador. & 6 \\
\hline
\end{tabular}

Tabela 4 - Tipologia de trabalhadores participantes do GTC.

Fonte: Elaboração própria a partir dos dados de pesquisa de campo. 
O nível hierárquico foi também homogêneo, com oito pessoas em diversos graus de chefia e onze chegando da área operativa.

O curso foi tanto teórico, com aulas conceituais, como prático, com apresentações e discussões de trabalhos de campo efetuados por duplas em nove áreas do hospital. O curso teve início em 2007 com duração de oito meses. Os participantes disponibilizaram uma sexta feira integral por mês (possibilitada pela permissão da instituição em liberá-los do próprio trabalho nos dias propostos).

Os resultados dos trabalhos finais de campo nas diferentes áreas do hospital foram todos apresentados no começo de 2009 na Escola Politécnica da USP, e singularmente em várias reuniões de chefias do HU-USP, a última em outubro de 2010. Muitas propostas de tais trabalhos resultaram em mudanças reais durante os períodos de estudo, tanto de pequeno porte como em projetos maiores com a execução de reformas em áreas inteiras, através da colaboração do $\mathrm{CM}$. Ainda não foram implementadas todas as propostas, já que este é um processo bem demorado que necessita também de apoio financeiro. A percepção do pesquisador é que continuarão sendo introduzidas melhorias partindo de tais trabalhos.

\subsubsection{1 - Analise das entrevistas}

Os trabalhadores envolvidos nas entrevistas foram todos os participantes do GTC. A seguir são apresentadas as respostas por tópico.

\section{Entrada no GTC}

A primeira informação que foi buscada por parte do pesquisador foi à efetiva voluntariedade da participação. A impressão é que a participação de alguma figura profissional estratégica a temática no hospital tenha sido obtida por meio de pressão.

As respostas foram encaixadas em quatro respostas principais:

- (1) participação totalmente voluntaria, ou seja, ao tomar conhecimento da proposta houve real interesse em participar 
- (2) participação voluntaria, mas seguida a um convite formal de um superior,

- (3) participação condicionada mais pelo convite de um superior do que por um interesse real,

- (4) participação condicionada a um convite que não podia ser recusado,

É necessário argumentar que a existência da voluntariedade nem sempre depende do interesse ou não nos assuntos discutidos, mas também das condições de tal curso, que exigiria dedicação e tempo.

Através de uma análise dos resultados presentes na tabela 5 é possível extrair que a metade dos participantes teve uma participação totalmente voluntária, enquanto só um foi "obrigado" a participar.

\begin{tabular}{|c|c|c|c|c|}
\hline \multirow{2}{*}{$\begin{array}{c}\text { Tipo de } \\
\text { trabalhador }\end{array}$} & \multicolumn{4}{|c|}{ Grau de volunt ariedade } \\
\cline { 2 - 5 } & $(1)$ & $(2)$ & $(3)$ & $(4)$ \\
\hline E & 3 & 1 & 1 & 0 \\
\hline F & 0 & 1 & 0 & 1 \\
\hline G & 5 & 1 & 0 & 0 \\
\hline H & 2 & 0 & 4 & 0 \\
\hline Tot & 10 & 3 & 5 & 1 \\
\hline
\end{tabular}

Tabela 5 - Grau de voluntariedade dos participantes do GTC.

Fonte: Elaboração própria a partir dos dados de pesquisa de campo.

Em referência à tipologia de trabalhador apresentada anteriormente, os mais "voluntários" foram os trabalhadores operativos das áreas críticas. Partindo do que foi verbalizado nas entrevistas, não ocorreu pressão alguma e todos mostraram interesse anterior em campos relacionados à temática e em melhorar o trabalho na própria área.

Um alto interesse foi mostrado também por parte dos trabalhadores das seções de Terapia Ocupacional e Fisiologia. A principal motivação é um altíssimo interesse pessoal em tais assuntos, mesmo o curso criando acúmulo de trabalho na própria área.

Esta ultima dificuldade é causa da baixa voluntariedade dos participantes das áreas estratégicas no cuidado da saúde do trabalhador. Pelo papel por eles exercido na organização, sua participação seria muito importante, e por isso foram 
particularmente convidados. A participação no curso, porém, provocou um grande acúmulo de trabalho.

Enfim, os chefes e representantes das áreas mais críticas foram muito condicionados pelos convites recebidos, principalmente por serem responsáveis pela saúde dos trabalhadores nas próprias áreas criticas.

\section{Conceitos aprendidos}

Discutindo sobre o curso, foi perguntado aos participantes sobre o conteúdo e o quanto foi aproveitado. Como apresentado na tabela 6, a maioria das pessoas percebeu aproveitamento do curso.

\begin{tabular}{|c|c|}
\hline \multicolumn{2}{|c|}{ Ampliou os próprios conhecimentos? } \\
\hline Sim & 15 \\
\hline Limitadamente & 2 \\
\hline Não & 1 \\
\hline
\end{tabular}

Tabela 6 - Conceitos aprendidos pelos participantes do GTC.

Fonte: Elaboração própria a partir dos dados de pesquisa de campo.

A pessoa que afirmou não ter ampliado os próprios conhecimentos, segundo o pesquisador, teve a percepção de que o curso não atendeu suas expectativas. Dois participantes ampliaram os próprios conhecimentos limitadamente, sobretudo devido ao nível do curso, muito elevado em comparação aos seus conhecimentos iniciais, e por isso difícil de ser seguido (também neste caso o curso não atendeu as expectativas). Este dado não tem correlações com a tipologia de trabalhador e com o grau de voluntariedade.

Entre aqueles que ampliaram os próprios conhecimentos, existe unanimidade em dizer que houve mudança no próprio olhar. Em geral, a visão da ergonomia era ligada à postura e ao mobiliário. Com o curso os participantes aprenderam que para obter uma melhoria da própria área seria necessário analisar outros aspectos como processos, atividades e relações pessoais. O curso permitiu também que alguns chefes das áreas críticas entendessem a importância de envolver o próprio funcionário na melhoria das condições de trabalho. (anexo $F$, falas 1) 
Para os Terapeutas Ocupacionais e Fisioterapeutas, a ampliação de visão permitiu aprender a importância da pesquisa de campo e da metodologia AET em analisar as situações dos pacientes, que simplifica o próprio trabalho (anexo $F$, fala 2). Através das falas 3, presentes no anexo $F$ são apresentadas duas verbalizações significativas sobre o novo olhar mais cuidadoso dos profissionais de tais setores do hospital.

\section{Trabalho prático no GTC}

Uma seção da entrevista foi dedicada à análise dos trabalhos práticos desenvolvidos pelos participantes durante o curso. Os resultados de tal parte da entrevista, por terem pouca relevância, não serão explicados em detalhe.

Levantamos, porém que os trabalhos práticos foram considerados positivamente, e uma avaliação negativa foi dada apenas por quem ainda não viu as próprias sugestões tornarem-se melhorias reais. Além disso, em geral, as pessoas não foram informadas sobre as mudanças reais ocorridas nas áreas estudadas (se, por exemplo, houve reformas, mudanças de processos, etc.) de maneira formal. Os poucos que se interessaram souberam das mudanças informalmente.

\section{Conhecimento de outras ações ergonômicas desenvolvidas no HU}

Aos participantes do GTC foi perguntado se conheciam outras ações ergonômicas desenvolvidas no $\mathrm{HU}$, principalmente a implementação do $\mathrm{CM}$ e ações isoladas de AET. Além disso, foi perguntado sobre o grupo LER-DORT e as ações de psicodinâmica. Também neste caso não entraremos nos detalhes das respostas, mas o resultado indicou que o conhecimento de tais ações, quando ocorria (poucas vezes) derivava de uma participação direta ou de informações recebidas informalmente. Traduzindo, o grupo não foi mais informado e atualizado, e a sua ação encerrou-se com as apresentações dos trabalhos práticos.

\section{Aplicação dos conhecimentos adquiridos no GTC}

A entrevista continuou discutindo a eficácia de tal grupo, identificando se os conhecimentos adquiridos são, ou não, aplicados na área de origem após o término 
do curso. Com esta pergunta foi possível descobrir quem aplica tais conhecimentos ativamente (5 pessoas), de modo limitado (9 pessoas) e quem não os aplica (4 profissionais). Na tabela 7 , além de apresentar em verde os resultados da pergunta, estes foram relacionados às outras respostas coletadas até o instante.

\begin{tabular}{|c|c|c|c|c|c|c|c|c|c|c|}
\hline \multirow{2}{*}{$\begin{array}{c}\text { Tipo de } \\
\text { trabalhad }\end{array}$} & \multicolumn{4}{|c|}{ Grau de volunt ariedade } & \multicolumn{3}{|c|}{ Ampliou os pr. conhecimentos? } & \multicolumn{3}{|c|}{ Os aplica? } \\
\hline & (1) & (2) & $(3)$ & (4) & Sim & Limitad. & Nao & Sim & Limitad. & Nao \\
\hline \begin{tabular}{l|l}
$E$ \\
\end{tabular} & 1 & & & & 1 & & & & 1 & \\
\hline $\mathrm{E}$ & 1 & & & & 1 & & & 1 & & \\
\hline$E$ & & 1 & & & 1 & & & 1 & & \\
\hline$E$ & & & 1 & & 1 & & & 1 & & \\
\hline$E$ & 1 & & & & 1 & & & & & \\
\hline $\mathrm{F}$ & & & & 1 & 1 & & & & & 1 \\
\hline $\mathrm{F}$ & & 1 & & & & & 1 & & & 1 \\
\hline G & 1 & & & & 1 & & & & 1 & \\
\hline $\mathrm{G}$ & 1 & & & & 1 & & & & 1 & \\
\hline $\mathrm{G}$ & 1 & & & & & 1 & & & & 1 \\
\hline G & 1 & & & & 1 & & & & 1 & \\
\hline $\mathrm{G}$ & & 1 & & & 1 & & & & 1 & \\
\hline $\mathrm{G}$ & 1 & & & & 1 & & & & 1 & \\
\hline $\mathrm{H}$ & & & 1 & & & 1 & & & & 1 \\
\hline $\mathrm{H}$ & & & 1 & & 1 & & & & 1 & \\
\hline $\mathrm{H}$ & 1 & & & & 1 & & & 1 & & \\
\hline $\mathrm{H}$ & & & 1 & & 1 & & & 1 & & \\
\hline $\mathrm{H}$ & 1 & & & & 1 & & & & 1 & \\
\hline $\mathrm{H}$ & & & 1 & & 1 & & & & 1 & \\
\hline & 10 & 3 & 5 & 1 & 16 & 2 & 1 & 5 & 9 & 4 \\
\hline
\end{tabular}

Tabela 7 - Aplicação dos conhecimentos adquiridos pelos participantes do GTC.

Fonte: Elaboração própria a partir dos dados de pesquisa de campo.

Elemento muito claro, marcado em cor laranja, identifica como a não aplicação dos conhecimentos na área de origem é estreitamente relacionada a quem teve uma participação condicionada a um convite que não podia ser recusado, ou a quem exprimiu não ter ampliado os próprios conhecimentos.

Analisando as respostas relacionadas ao tipo de trabalhador:

- Os terapeutas ocupacionais e os fisioterapeutas estão aplicando estes novos conhecimentos dentro do próprio trabalho. As verbalizações permitiram entender que atualmente existe um maior cuidado na análise da relação do trabalho do assistido com aquele das áreas limítrofes, de ir até o lugar de trabalho do paciente se necessário, e a importância da análise dos processos. O único profissional que mostrou uma aplicação limitada dos conhecimentos não o fez exclusivamente por falta de tempo. 
- Quem trabalha nas áreas estratégicas para o cuidado da saúde do trabalhador não aplica os conhecimentos de ergonomia. Neste caso, porém, não é possível generalizar os resultados pela categoria de trabalhadores. Foi muito claro para o entrevistador que os dois profissionais não entraram no grupo de um modo totalmente positivo; um por não poder recusar o convite e o outro entrou com enfoque bem diferente e acabou não aproveitando o curso.

- Os sujeitos do grupo da área operacional aplicam limitadamente o que foi aprendido. Através das verbalizações foi possível entender como estes participantes sofrem pela sua posição hierárquica. Dos seis, três gostariam de aplicar os próprios conhecimentos e ter papel ativo na instituição, reconhecem que podem melhorar pequenas coisas no trabalho diário, mas ficam muito limitados para participar de projetos de melhoria mais amplos (anexo F, falas 4). Em tal contexto tais participantes não se propõe ativamente em sugerir melhorias.

- Participantes de áreas criticas com poderes de chefia ou de coordenador, em geral aplicam os conhecimentos, também se de modo limitado. Os chefes e os coordenadores apresentam maior liberdade para aplicar os próprios conhecimentos em comparação aos participantes da área operacional, sendo responsáveis por áreas definidas. Com isso, eles também reconhecem os limites de terem influência em uma esfera delimitada, aonde existem aspectos fora do seu alcance (anexo $\mathrm{F}$, fala 5). Muda exclusivamente a amplitude da esfera de influência em relação ao participante anterior. Um aspecto reconhecido por muitas pessoas é a dificuldade em estudar processos partindo de um olhar interno e viciado da rotina de trabalho (anexo $F$, fala 6). Entre as pessoas que não conseguiram aplicar plenamente os assuntos aprendidos, dois profissionais relataram o problema da falta de tempo como elemento condicionante. Quem considera aplicar completamente os novos conhecimentos, em geral reconhece a própria esfera de ação e o quanto podem alcançar. Observam-se duas atitudes: a primeira é dos chefes que consideram exclusivamente o que pode ser feito na área independentemente da ajuda ou suporte do externo, a segunda, e mais proativa, é daqueles que buscam soluções e, quando sabem que estas se encontram fora do próprio alcance buscam quem tenha poder para realizá-las (anexo F, fala 7). Um elemento a ser extraído de tais entrevistas é que ninguém informou espontaneamente (embora parecesse que 
chefes o tenham feito com postura mais proativa) ter espalhado os conhecimentos aprendidos no curso dentro da própria área de origem.

\section{Suporte da organização}

Um elemento considerado relevante pelo pesquisador para o sucesso de tal grupo é o grau de comprometimento da organização diante dos participantes. Com tal foco foi perguntado sobre o apoio recebido antes, durante, e depois do curso.

Antes e durante o curso, as respostas foram unânimes em considerar o apoio da organização como muito positivo. Como elementos muito importantes foram considerados o fato de a instituição ter possibilitado a participação do curso durante o horário de trabalho, de ter convidado profissionais externos (da Escola Politécnica) e de possibilitar projetos práticos nas áreas ergonomicamente mais críticas, além de disponibilizar a estrutura.

Depois do curso, partindo das entrevistas, o apoio da organização foi diminuindo, como apresentado na tabela 8.

\begin{tabular}{|c|c|c|c|c|}
\hline \multicolumn{5}{|c|}{ Suporte da organização depois do curso } \\
\hline Ótimo & Bom & Neutro & Ruim & Muito ruim \\
\hline $1^{*}$ & 4 & 2 & 6 & 5 \\
\hline
\end{tabular}

Tabela 8 - Suporte da organização depois do curso no GTC.

Fonte: Elaboração própria a partir dos dados de pesquisa de campo.

Entrando rapidamente nos detalhes de cada avaliação:

- Ótimo: foi respondido por um único entrevistado, e que foi também o único que não realizou a entrevista oral por indisponibilidade, mas sim entrevista via e-mail. Segundo o pesquisador tal resposta foi muito superficial (observando também sua extensão) e por isso pode não ser considerada na análise,

- Bom: foi respondido por aqueles profissionais que enxergaram a proposta simplesmente como um curso sem obrigatoriedade de uma continuação e/ou entendendo que o $\mathrm{HU}$ deu grande suporte e o andamento sucessivo foi devagar por causas naturais, devido a recursos limitados em comparação com o número de sugestões levantadas nos trabalhos práticos. 
- Neutro: apresenta os casos das pessoas que, entendendo a boa intenção de quem possibilitou o curso e trouxe a temática para a organização, não conseguiu planejar ações futuras (anexo $\mathrm{F}$, fala 8).

- Ruim: foi respondido por todos que tinham a expectativa de haver uma continuação do grupo, ou pelo menos de propostas de ergonomia, que não aconteceram.

- Muito ruim: foi a resposta de quem entrou com motivação, sentiu faltar apoio e interesse da organização (anexo $F$, falas 9).

Um exemplo que foi dado por seis pessoas sobre o grau de apoio da diretoria após o curso, foi sobre a sua participação nas apresentações. Duas pessoas falaram positivamente, enquanto outras quatro, falaram negativamente, afirmando que quem teria poder para possibilitar as melhorias não estava presente, transmitindo uma idéia de desinteresse.

\begin{tabular}{|c|c|c|c|c|c|c|c|c|c|c|c|}
\hline \multirow{2}{*}{$\begin{array}{c}\text { Tipo de } \\
\text { trabalhad }\end{array}$} & \multicolumn{4}{|c|}{ Grau de voluntariedade } & \multicolumn{3}{|c|}{ Ampliou os pr. conhecimentos? } & \multicolumn{3}{|c|}{ Os aplica? } & \multirow{2}{*}{$\begin{array}{l}\text { Suporte } \\
\text { depois }\end{array}$} \\
\hline & (1) & (2) & (3) & (4) & sim & Limitad. & Nao & Sim & Limitad. & Nao & \\
\hline E & & 1 & & & 1 & & & 1 & & & Bom \\
\hline$E$ & 1 & & & & 1 & & & 1 & & & Bom \\
\hline $\mathrm{H}$ & 1 & & & & 1 & & & 1 & & & Bom \\
\hline $\mathrm{H}$ & & & 1 & & 1 & & & 1 & & & Bom \\
\hline $\mathrm{H}$ & & & 1 & & 1 & & & & 1 & & Bom \\
\hline$E$ & & & 1 & & 1 & & & 1 & & & Neutro \\
\hline $\mathrm{G}$ & 1 & & & & 1 & & & & 1 & & Neutro \\
\hline$E$ & 1 & & & & 1 & & & & 1 & & Ruim \\
\hline$F$ & & & & 1 & 1 & & & & & 1 & Ruim \\
\hline G & 1 & & & & 1 & & & & 1 & & Ruim \\
\hline$\underline{\mathrm{H}}$ & & & 1 & & & 1 & & & & 1 & Ruim \\
\hline $\mathrm{H}$ & & & 1 & & 1 & & & & 1 & & Ruim \\
\hline $\mathrm{H}$ & 1 & & & & 1 & & & & 1 & & Ruim \\
\hline E & 1 & & & & 1 & & & 1 & & & Mt ruim \\
\hline$F$ & & 1 & & & & & 1 & & & 1 & Mt ruim \\
\hline G & 1 & & & & 1 & & & & 1 & & Mt ruim \\
\hline G & 1 & & & & & 1 & & & & 1 & Mt ruim \\
\hline G & 1 & & & & 1 & & & & 1 & & Mt ruim \\
\hline
\end{tabular}

Tabela 9 - Suporte da organização depois do curso no GTC, relacionado a outras variáveis.

Fonte: Elaboração própria a partir dos dados de pesquisa de campo.

Existem algumas correlações entre as respostas (tabela 9). Conforme o piorar da avaliação sobre o suporte da organização depois do curso:

- o grau de voluntariedade inicial foi melhor,

- a pessoa teve menor aproveitamento no curso,

- a pessoa aplica menos os conhecimentos de ergonomia aprendidos, 
- o entrevistado não provém da chefia, mas da área operacional.

Elemento importante para explicar tais resultados é que a satisfação dos participantes deriva do seu grau de expectativa sobre o curso e/ou (menos) da abrangência do próprio poder em implementar melhorias ergonômicas. Muitas pessoas entraram com uma expectativa muito alta, que, porém não foi atendida. Em geral quem teve maior expectativa teve também maior desmotivação (anexo $\mathrm{F}$, fala 10). Interessante seria analisar a visão de um entrevistado que observasse um aspecto de marketing do hospital ao preocupar-se com os problemas de saúde (anexo F, fala 11).

\section{Dificuldades encontradas no GTC}

As principais dificuldades, verbalizadas de modo espontâneo, foram:

- Falta de tempo, verbalizado por sete pessoas, indica que segundo as mesmas o curso ocupou muito tempo. Mesmo sendo liberados para participarem do curso voltava na própria área com o trabalho acumulado por não terem nenhum substituto, além de precisar dedicar tempo fora do curso para o trabalho de campo. Não é uma casualidade que quem comentou esta dificuldade foram quatro chefes (sobre seis), os dois das áreas estratégicas para o cuidado da saúde do trabalhador, e uma pessoa entre os terapeutas e fisioterapeutas (como apresentado na tabela 10). Esta dificuldade teve impacto direto no grau de voluntariedade na entrada do projeto e na aplicação dos conhecimentos aprendidos.

\begin{tabular}{|l|c|c|c|c|c|c|c|c|c|c|}
\multirow{2}{*}{$\begin{array}{c}\text { Tipo de } \\
\text { trabalhad }\end{array}$} & \multicolumn{4}{|c|}{ Grau de voluntariedade } & Ampliou os pr. conhecimentos? & \multicolumn{3}{c|}{ Os aplica? } \\
\cline { 2 - 11 } & $(1)$ & $(2)$ & $(3)$ & $(4)$ & Sim & Limitad. & Nao & Sim & Limitad. & Nao \\
\hline $\mathrm{E}$ & & & 1 & & 1 & & & 1 & & \\
\hline $\mathrm{F}$ & & & & 1 & 1 & & & & & 1 \\
\hline $\mathrm{F}$ & & 1 & & & & & 1 & & & 1 \\
\hline $\mathrm{H}$ & & & 1 & & & 1 & & & & 1 \\
\hline $\mathrm{H}$ & & & 1 & & 1 & & & & 1 & \\
\hline $\mathrm{H}$ & & & & & 1 & & & & 1 & \\
\hline
\end{tabular}

Tabela 10 - Respostas de quem acha que o GTC tomou tempo demais deles.

Fonte: Elaboração própria a partir dos dados de pesquisa de campo.

- O conjunto de participantes do grupo não é ideal, explicado por quatro participantes, dizendo que o nível de conhecimento de base requerido pelo curso foi 
praticamente proibitivo para eles (anexo F, falas 12). Como apresentado na tabela 11 este foi o caso de participantes majoritariamente da área operacional e de quem pouco aplicou os conhecimentos aprendidos no curso.

\begin{tabular}{|l|c|c|c|c|c|c|c|c|c|c|}
\multirow{2}{*}{$\begin{array}{c}\text { Tipo de } \\
\text { trabalhad }\end{array}$} & \multicolumn{4}{|c|}{ Grau de voluntariedade } & Ampliou os pr. conhecimentos? & \multicolumn{3}{c|}{ Os aplica? } \\
\hline & $(1)$ & $(2)$ & $(3)$ & $(4)$ & Sim & Limitad. & Nao & Sim & Limitad. & Nao \\
\hline F & & & & 1 & 1 & & & & & 1 \\
\hline G & 1 & & & & 1 & & & & 1 & \\
\hline H & 1 & & & & & 1 & & & & 1 \\
\hline
\end{tabular}

Tabela 11 - Respostas de quem acha que o GTC teve um conjunto de participantes não ideal.

Fonte: Elaboração própria a partir dos dados de pesquisa de campo.

- Falta de informações iniciais, informada por quatro pessoas (três das quais expressaram também falta de tempo) indicou como algumas pessoas entraram no curso sem saber as condições mínimas, como programação e carga horária.

- Sobre o curso, aonde encontramos várias queixas. Uma foi sobre a alta carga de trabalho a e outra foi sobre a repetitividade de algumas partes, como por exemplo, das apresentações (anexo F, falas 13).

- Falta de incentivo, indicado por um único entrevistado, o qual viu o curso como um aumento de tarefas na própria rotina (anexo F, fala 14).

- Falta de objetivos claros e explícitos.

Embora a presença de tais problemáticas, as pessoas do grupo gostariam que a temática tivesse continuidade com outros cursos e que a pudessem utilizar na prática.

\section{Sugestões sobre o GTC}

$\mathrm{Na}$ última parte da entrevista foi possibilitada a abertura para sugestões. As principais foram:

- Introduzir novos cursos de ergonomia no hospital, aconselhado por oito participantes, incluindo um eventual segundo nível para quem participou, e/ou outros cursos para novos funcionários e/ou especializações externas ao hospital. Isso indica que houve envolvimento geral, embora as problemáticas. 
- Aumentar a divulgação da temática em toda a instituição, como por exemplo, através de cartazes para chamar a atenção para a temática, sugerido por duas pessoas.

- Envolver diretamente outras pessoas chave como Superintendência e SESMT, e aumentar o número de terapeutas ocupacionais e fisioterapeutas.

- Introduzir um grupo permanente cuidando do assunto, ligado à Superintendência e à Escola Politécnica (na prática, um CM), com planejamento preventivo.

- Ter um coordenador e uma pessoa de referência em assuntos ergonômicos, sendo que vêem dificuldade em transmitir pessoalmente tais conceitos uma vez acabado o curso (anexo F, fala 15).

\subsection{3 - Disseminação de conceitos ergonômicos entre os gestores}

A seguir são apresentados vários tópicos da entrevista com os gestores

\section{Conhecimentos da temática da ergonomia entre os gestores}

As entrevistas permitiram obter informações sobre os conhecimentos de base dos gestores relacionados à temática da ergonomia. Foram coletadas muitas definições e, para medir e comparar o grau de conhecimento entre grupos de gerentes, o entrevistador pediu aos entrevistados que fizessem uma lista de quais elementos a ergonomia estuda. Para simplificar a coleta de dados as respostas foram cadastradas em oito macro-categorias: equipamentos de trabalho, ambiente e layout, postura, área psicológico-emocional, nível da organização, atividades, relações internas à própria equipe, e relações com as equipes de trabalhadores externas. As entrevistas não foram induzidas, sendo as respostas totalmente espontâneas. Os dados foram divididos também segundo quatro grupos de gerentes:

- (A) Enfermeiros, os quais foram envolvidos em algumas ações ergonômicas antecedentemente,

- (B) Médicos, que não tiveram contato com ações de ergonomia, 
- (C) Outros que foram envolvidos em ações de ergonomia (chefes do SAME, Arquivo Médico e Estatística, Fisioterapia, Nutrição, Higiene Especializada, Compras e Manutenção e Engenharia Hospitalar),

- (D) Outros que não foram envolvidos diretamente em ações de ergonomia

$\mathrm{Na}$ tabela 12 os resultados descrevem como para os entrevistados a ergonomia analisa principalmente os equipamentos, a postura e o lado ambiental, enquanto só a metade achou que este tema analisa as atividades, e menos de um terço os aspectos psicológicos - emocionais. Só $10 \%$ ou menos discutiu sobre as restantes macro-categorias.

\begin{tabular}{|c|c|c|c|c|c|c|c|c|c|}
\hline & Equip. & Postura & Ambiente & Atividades & Psicológico & Rel. int. & Rel. ext. & Organiz. & TOT. \\
\hline A & 18 & 15 & 15 & 11 & 5 & 2 & 2 & 2 & 21 \\
\hline B & 6 & 7 & 5 & 4 & 1 & 0 & 0 & 0 & 8 \\
\hline C & 7 & 5 & 7 & 6 & 6 & 3 & 3 & 1 & 7 \\
\hline D & 7 & 8 & 5 & 3 & 2 & 0 & 0 & 0 & 10 \\
\hline & 38 & 35 & 32 & 24 & 14 & 5 & 5 & 3 & 46 \\
\hline
\end{tabular}

Tabela 12 - Respostas da pergunta feita aos gerentes sobre qual o objeto de estudos ergonômicos.

Fonte: Elaboração própria a partir dos dados de pesquisa de campo.

Maior é o conhecimento de ações de ergonomia na instituição e proporcionalmente melhor é a resposta a tal pergunta, como mostrado na tabela 13. Por exemplo, mesmo tendo um nível de estudo reconhecido como superior, os médicos enxergam a ergonomia de um modo mais limitado que os enfermeiros.

\begin{tabular}{|c|c|c|c|c|c|c|c|c|}
\hline & Equip. & Postura & Ambiente & Atividades & Psicológico & Rel. int. & Rel. ext. & Organiz. \\
\hline A & $85,7 \%$ & $71,4 \%$ & $71,4 \%$ & $52,4 \%$ & $23,8 \%$ & $9,5 \%$ & $9,5 \%$ & $9,5 \%$ \\
\hline B & $75,0 \%$ & $87,5 \%$ & $62,5 \%$ & $50,0 \%$ & $12,5 \%$ & $0,0 \%$ & $0,0 \%$ & $0,0 \%$ \\
\hline C & $100,0 \%$ & $71,4 \%$ & $100,0 \%$ & $85,7 \%$ & $85,7 \%$ & $42,9 \%$ & $42,9 \%$ & $14,3 \%$ \\
\hline \multirow[t]{2}{*}{ D } & $70,0 \%$ & $80,0 \%$ & $50,0 \%$ & $30,0 \%$ & $20,0 \%$ & $0,0 \%$ & $0,0 \%$ & $0,0 \%$ \\
\hline & $82,6 \%$ & $76,1 \%$ & $69,6 \%$ & $52,2 \%$ & $30,4 \%$ & $10,9 \%$ & $10,9 \%$ & $6,5 \%$ \\
\hline
\end{tabular}

Tabela 13 - Respostas da pergunta feita aos gerentes sobre qual o objeto de estudos ergonômicos (em porcentagem).

Fonte: Elaboração própria a partir dos dados de pesquisa de campo. 


\section{Dificuldades ergonômicas verbalizadas pelos gestores}

Explicado o termo mais amplo da ergonomia a todos os entrevistados, foi pedido para que fizessem uma lista de todas as principais problemáticas presentes na própria área de atuação. Reunindo as respostas nas oito macro-categorias anteriores, os resultados são visíveis na ilustração 8.

\begin{tabular}{|l|c|}
\hline \multicolumn{1}{|c|}{ Tipologia } & N. queixas \\
\hline Ambiente & 42 \\
\hline Atividades & 34 \\
\hline Equipamentos & 32 \\
\hline Organização & 30 \\
\hline Postura & 11 \\
\hline Psicológico & 16 \\
\hline Relações ext. & 4 \\
\hline Relações int. & 1 \\
\hline & 170 \\
\hline
\end{tabular}

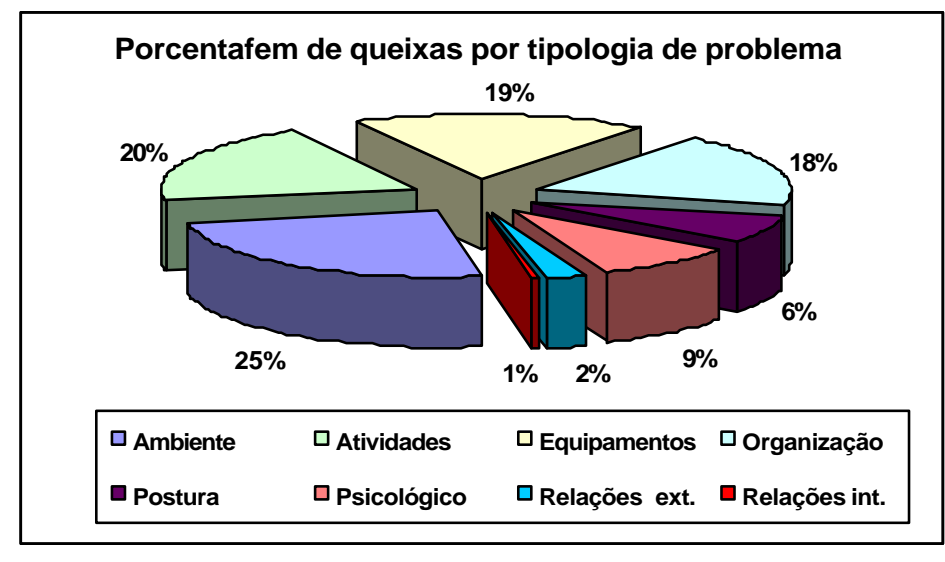

Ilustração 8 Dificuldade ergonômicas verbalizadas pelos gestores.

Fonte: Elaboração própria a partir dos dados de pesquisa de campo.

Não é possível fazer uma comparação entre as quantidades de queixas entre as macro-categoria, sendo as problemáticas diferentes e com impacto no bem estar dos trabalhadores bem variáveis. Sobre os equipamentos obtivemos doze queixas sobre cadeiras e mesas, e outras vinte de outros equipamentos; Sobre o ambiente, sete com ruídos, cinco com iluminação, doze com layout em geral, quatorze com layout pequeno se comparado ao necessário, dois devido ao hospital ser velho (com estruturas não tão funcionais) e dois do ambiente não ter uma boa aparência estética. Sobre posturas, houve seis queixas sobre a presença de movimentos repetitivos e cinco sobre a obrigação de ter uma determinada postura física inadequada durante o trabalho; nos psicológicos, existem problemas de estresse, em particular sob a presença de pacientes entre a vida e a morte. Sobre o lado da organização, temos dezesseis queixas sobre a falta de sensibilização dos próprios funcionários com a temática ergonômica, nove sobre uma diminuição do próprio quadro de funcionários, três sobre a baixa rotatividade dos funcionários e um aumento da idade média (existe uma crítica direta ao fato de possibilitar que pessoas aposentadas continuem trabalhando) e duas sobre a falta de programas corretivos como ginástica laboral. Das trinta e quatro queixas sobre as atividades, 
quatro são sobre horários, quinze sobre altas cargas de peso, sete sobre a presença de pessoas com restrições, as quais causam mais trabalho para os demais, e oito sobre processos em geral. Na categoria das relações externas entram todas aquelas pressões que outros departamentos exercem para ter uma maior produtividade, de um departamento gargalo para a produtividade geral da empresa. A única queixa sobre relações internas foi detectada em uma equipe onde havia pessoas com restrições, as quais são vistas negativamente pelos demais, que se sentem sobrecarregados.

\section{Conhecimento de ações de tipo ergonômico no HU-USP pelos gestores}

$\mathrm{Na}$ entrevista aos gestores foi perguntado sobre o seu conhecimento sobre ações ergonômicas desenvolvidas no $\mathrm{HU}$, e em caso afirmativo para falar dos detalhes que conhecem. De tal modo foi possível identificar o grau de conhecimento de cada ação ergonômica desenvolvida no hospital.

Para simplificar, as respostas foram cadastradas pelo pesquisador em quatro principais:

- (0) Nunca ouvi falar sobre tal assunto no HU-USP;

- (1) Já ouvi falar o nome, mas não conhece os argumentos tratados em tal ação;

- (2) Conhece os principais assuntos tratados, mas não os detalhes;

- (3) Conhece bem as propostas no HU-USP.

Pode-se afirmar que as primeiras duas respostas indicam que o entrevistado não conhece tais ações ergonômicas.

Conhecimento de ações de tipo ergonômico - GTC.

Sobre o GTC, as respostas são apresentadas na tabela 14 .

Esta ação ergonômica é conhecida por mais da metade dos entrevistados $(58,7 \%)$ embora seja conhecida bem apenas por cerca de um quarto dos gestores (26\%). Observando os grupos; chefes da enfermagem (A) e dos outros departamentos que foram envolvidos em ações de ergonomia (C) tiveram melhores conhecimentos, enquanto os médicos foram os menos informados. O que possibilitou que tantas 
pessoas ficassem conhecendo o GTC foi pela participação direta, ou por terem assistido à apresentação dos trabalhos finais nas reuniões de chefias.

\begin{tabular}{|c|c|c|c|c|c|}
\cline { 2 - 6 } \multicolumn{1}{c|}{} & $(0)$ & $(1)$ & $(2)$ & $(3)$ & \\
\hline$A$ & 1 & 4 & 9 & 7 & 21 \\
\hline$B$ & 4 & 2 & 2 & 0 & 8 \\
\hline$C$ & 0 & 1 & 2 & 4 & 7 \\
\hline$D$ & 1 & 4 & 4 & 1 & 10 \\
\hline & 6 & 11 & 17 & 12 & 46 \\
\hline
\end{tabular}

Tabela 14 - Conhecimento de ações de tipo ergonômico pelos gestores - GTC.

Fonte: Elaboração própria a partir dos dados de pesquisa de campo.

Quem conhece bem esta ação e os seus resultados tem ótima consideração da mesma (anexo F, falas 16), e existem chefes, sobretudo da enfermagem, que teriam gostado de participar e apontar como principal culpa a baixa divulgação.

Esta ação foi considerada útil porque permitiu sensibilizar as chefias, ampliando a visão sobre o trabalho de outras equipes no hospital. Como exemplo, um chefe da área médica comentou, fazendo referencia à equipe de hotelaria, que descobriu o quanto eles estão exposto a riscos de saúde, e por isto trocou atitudes na própria rotina de trabalho em favor deles.

Quem conhece pouco sobre tais ações e apresentações dos participantes do GTC, afirma que o assunto da ergonomia é muito específico a respeito do número de atividades e pesquisas que são desenvolvidas no HU-USP a cada dia.

Conhecimento de ações de tipo ergonômico - CM

Sobre o CM, os resultados são apresentados na tabela 15.

\begin{tabular}{|c|c|c|c|c|c|}
\cline { 2 - 6 } \multicolumn{1}{c|}{} & $(0)$ & $(1)$ & $(2)$ & $(3)$ & \\
\hline A & 14 & 4 & 1 & 2 & 21 \\
\hline$B$ & 5 & 2 & 1 & 0 & 8 \\
\hline C & 1 & 4 & 1 & 1 & 7 \\
\hline$D$ & 9 & 1 & 0 & 0 & 10 \\
\hline & 29 & 11 & 3 & 3 & 46 \\
\hline
\end{tabular}

Tabela 15 - Conhecimento de ações de tipo ergonômico pelos gestores - CM.

Fonte: Elaboração própria a partir dos dados de pesquisa de campo. 
Poucos foram os chefes que tiveram conhecimento sobre o $\mathrm{CM}$, sendo tal ação divulgada quase exclusivamente para quem participou dele. Excluindo os dois chefes que participaram diretamente, as outras quatro pessoas que conhecem qualquer informação deste meio organizativo a obtiveram de modo informal.

Conhecimento de ações de tipo ergonômico - Comentários finais

A entrevista permitiu levantar muitas outras ações (também os estudos de AET) que foram desenvolvidas no hospital para melhorar a saúde dos trabalhadores.

Ficou claro com as entrevistas que todas estas ações de tipo ergonômico não foram bem definidas e claras para os trabalhadores da instituição durante sua introdução. Também os chefes não têm sempre claras as delimitações de cada uma, resultando assim numa mistura de pequenos conhecimentos soltos de ações ergonômicas e não ergonômicas.

\section{$\underline{\text { Relação entre as ações de ergonomia e melhorias nas condições de trabalho }}$}

A entrevista continuou discutindo se nos últimos anos os gestores conseguiram perceber melhorias no próprio trabalho. As respostas foram cadastradas em cinco possibilidades:

- (0) Não houve melhorias,

- (1) Houve uma melhoria natural ao longo do tempo,

- (2) Houve uma melhoria continua e gradual no cuidado das condições de trabalho devido a políticas da empresa,

- (3) Houve grandes melhorias, mas a ergonomia não teve papel principal,

- (4) Houve grandes melhorias ligadas estritamente às ações de ergonomia.

Os resultados de tal pergunta são apresentados na tabela 16 (nem todas as pessoas responderam). Partindo dos resultados podemos constatar que segundo o parecer dos gestores as condições de trabalho dos funcionários do HU melhoraram sensivelmente. 


\begin{tabular}{|c|c|c|c|c|c|c|c|}
\cline { 2 - 8 } \multicolumn{1}{c|}{} & $(0)$ & $(1)$ & $(2)$ & $(3)$ & $(4)$ & SR & \multicolumn{1}{c|}{} \\
\hline A & 1 & 2 & 3 & 2 & 10 & 3 & 21 \\
\hline B & 1 & 0 & 1 & 6 & 0 & 0 & 8 \\
\hline C & 0 & 0 & 0 & 1 & 4 & 2 & 7 \\
\hline$D$ & 1 & 1 & 1 & 4 & 1 & 2 & 10 \\
\hline & 3 & 3 & 5 & 13 & 15 & 7 & 46 \\
\hline
\end{tabular}

Tabela 16 - Relação entre as ações de ergonomia e melhoria nas condições de trabalho. (SR = sem resposta).

Fonte: Elaboração própria a partir dos dados de pesquisa de campo.

Do lado oposto, quem analisou as mudanças num nível mais global e respondeu como (3) e (4), identificou como causas principais de grandes mudanças pelo menos um dos três eventos:

- A troca de superintendente (desde 2002) e conseqüentemente da mudança da política da empresa. Ao período antecedente, considerado sem cuidados com as condições de trabalho ("Antes o HU era um hospital de terror, maluco. Tinha muita pressão") são contrapostas várias melhorias a partir da época da troca do superintendente.

- A introdução de pesquisas com o objetivo de melhorar o bem estar do trabalhador elou a eficiência e eficácia do trabalho no $\mathrm{HU}$, independentemente das mudanças na diretoria do HU. É neste contexto que as ações ergonômicas tiveram grande impacto, sobretudo o GTC.

- O alto número de funcionários afastados, aonde as melhorias foram obrigatórias para a situação não piorar ulteriormente (como explicado na introdução).

Precisamos contextualizar que tal pergunta foi inserida numa entrevista para levantar feedbacks sobre ações ergonômicas, e por isso pode ter tido influências nas respostas. Ficou claro que para quem participou das ações a ergonomia teve um grande papel na melhoria das condições de trabalho na instituição (anexo $F$, falas 17).

A seguir, a tabela 17 mostra a relação entre as respostas sobre a última questão a respeito da percepção de melhoria no cuidado das condições de trabalho nos últimos anos e o nível de conhecimento da ação ergonômica mais divulgada (o GTC). 


\begin{tabular}{|c|c|c|c|c|c|c|c|c|}
\hline & \multicolumn{6}{|c|}{ Percebeu melhorias nos ultimos anos? } & \\
\hline & & $(0)$ & (1) & $(2)$ & (3) & (4) & SR & \\
\hline \multirow{4}{*}{$\begin{array}{l}0 \\
0 \\
\circ \\
8 \\
8 \\
\overline{0} \\
\overline{0}\end{array}$} & (0) & 1 & & 2 & 2 & & 1 & 6 \\
\hline & (1) & 1 & 1 & 2 & 5 & & 2 & 11 \\
\hline & (2) & & 2 & 3 & 3 & 7 & 2 & 17 \\
\hline & (3) & & 1 & & 1 & 8 & 2 & 12 \\
\hline & & 2 & 4 & 7 & 11 & 15 & 7 & 46 \\
\hline
\end{tabular}

Tabela 17 - Relação entre conhecimento do GTC e percepção de melhorias entre os gerentes.

Fonte: Elaboração própria a partir dos dados de pesquisa de campo.

A relação que podemos extrair é que quem chegou a conhecer as aplicações práticas de ergonomia, em geral acredita que tal temática teve impacto positivo na melhoria das condições de trabalho no HU-USP.

\subsection{4 - Visão do projeto de ergonomia por parte da direção da empresa - assessora}

É introduzida a visão da assessora coordenadora sobre todos os projetos de ergonomia desenvolvidos no HU-USP. A seguir são introduzidas as principais afirmações do encontro, começando pela sua atuação como assessora na organização. Por comodidade os assuntos serão divididos por tópicos.

\section{Poder do assessor frente o superintendente}

A assessoria é um cargo de indicação, e tudo aquilo que este ator faz tem que ser comunicado ao superintendente, o qual pode autorizá-lo ou não. O assessor então pensa estrutura, escreve e, se o superintendente concorda, atua. Este cargo na prática não tem autonomia e trabalha com fortes limitações. No caso da ação ergonômica, por exemplo, quando se sentiu a necessidade de construir um sistema informatizado para controle epidemiológico das doenças profissionais, buscaram-se recursos externo através da FAPESP. 


\section{Alcançou-se os objetivos? Houve um plano de fundo?}

Houve uma melhoria contínua, uma grande sensibilização em assuntos ergonômicos em todo o hospital e muitas coisas concretas ficou, porém existem muitas oportunidades que poderiam e podem ainda ser feitas.

Do lado estratégico houve a necessidade de melhorias nas condições de trabalho dos funcionários do hospital, mas as ações ergonômicas não tinham prioridade. Não havia um plano estruturado em longo prazo, nem qual seria o passo sucessivo dos estudos ergonômicos. O projeto tornou-se grande frente à demanda inicial e, no final, foi um trabalho de muito impacto. Foi tudo construído passo a passo, sempre observando as possibilidades existentes. O seu envolvimento foi casual ("Nunca me imaginei voltada ao assunto de ergonomia").

\section{$\underline{\text { Resumo da trajetória ergonômica sob o olhar da assessora }}$}

Partindo da demanda inicial de resolver o problema dos funcionários afastados do INSS, o projeto foi se ampliando e alcançando resultados muito positivos através de ações práticas e de outros aspectos não mensuráveis. Do lado prático existem todos os projetos que se tornaram realidade através de melhorias e reformas, motivadas pelo GTC e do projeto da FAPESP sobre o sistema informático para controle epidemiológico das doenças profissionais que irá permitir no futuro a mensuração e monitoramento das doenças ocupacionais no $\mathrm{HU}$.

O aspecto não mensurável é a sensibilização de muitos atores do HU sobre esta causa, fazendo entender a importância da melhoria do processo, de comprar equipamentos mais adequados, e em geral de melhorar o olhar da organização sobre os aspectos ergonômicos.

Apesar das limitações, os resultados das ações ergonômicas no HU foram extremamente positivos.

\section{Visão final}

O projeto de ergonomia gerou impacto em todos os setores do hospital. Existem queixas de dor em todos os setores, o hospital esta sobrecarregado, precisa-se de mais funcionários e de melhorias de processos; ao abarcar um projeto como este é 
possível proporcionar melhorias no hospital como um todo. As possibilidades de atuação são muitas, com as evidências levantadas é possível convencer um gestor superior sobre as necessidades reais do hospital (precisar contratar mais pessoas, comprar equipamentos melhores, etc.) e de se engajar ainda mais neste assunto.

A assessora constatou que ao fazer parte de tal projeto foi possível conhecer cada problema do hospital, tendo uma visão muito mais ampla. Isso a levou a se engajar muito no projeto, e embora sabendo ter uma atuação limitada, tentou dentro dos próprios limites resolver os problemas apresentados, sobretudo tendo poucos recursos e uma baixa visibilidade do projeto no hospital, além de abrir novas oportunidades.

\subsection{5 - Visão do projeto de ergonomia por parte da direção da empresa - Superintendente}

A seguir é introduzida a visão do superintendente sobre a temática da ergonomia e sobre todos os projetos relacionados, desenvolvidos no HU-USP. Esta foi levantada em entrevista aberta executada em dezembro de 2010, na fase final da participação do autor no projeto. A seguir são introduzidas as principais afirmações do encontro, as quais foram entregues e validadas diretamente pelo entrevistado. Por comodidade os assuntos serão divididos por tópicos.

\section{Sobre a questão ergonômica em geral}

A questão da saúde dos trabalhadores sempre foi uma coisa que preocupou muito dentro da instituição.

No caso do hospital, como para o Brasil, a crítica ergonômica principal deve ser feita sobre os produtos, antes que sobre os processos de trabalho. A maioria dos produtos presentes no hospital é inadequado, como por exemplos as macas, as camas e as cadeiras de rodas, as quais causam dificuldades imensas para os trabalhadores. O problema principal é não conseguir encontrar no mercado nacional produtos válidos do ponto de vista ergonômico. No setor de limpeza, por exemplo, a qualidade dos equipamentos nacionais não é boa, tendo aspiradores de pó que não 
aspiram, por exemplo. Tendo produtos ruins, conseqüentemente é necessário esforço físico maior de quem trabalha com os mesmos. Houve a tentativa de implementar carrinhos automáticos de limpeza, mas existem muitas restrições e dificuldades em comprar equipamentos importados no serviço público.

Talvez, o aparente desprezo em adotar equipamentos e estabelecer processos que atendam a ergonomia no Brasil decorre da mão-de-obra barata, sendo que não se faz necessário investir em novas máquinas quando é possível substituí-las por pessoas. Isso vale para a iniciativa privada que contrata pessoas jovens com baixos salários por um tempo mínimo e, uma vez que estes são esgotados são dispensados, renovando sempre a mão-de-obra. Em setores públicos como o caso do hospital isso não existe, a demissão precisa ser justificada, e o tempo de exposição a atividades prejudiciais e os riscos vão sempre aumentando. Este é o grande drama do HU-USP.

A questão do processo de trabalho é outro fator importante, mas secundário. Por exemplo, um setor que demonstrou precisar de grandes melhorias foi o da nutrição e dietética. Neste as ferramentas de trabalho são razoáveis, enquanto a questão de processo é muito complicada. No exemplo do trabalho com legumes, no passado estes chegavam in natura e eram trabalhados, enquanto hoje chegam já processados. Isso permitiu melhorar muito as condições de trabalho no setor, mas houve uma dificuldade em aplicar a mudança devido à idéia pré-concebida de que os produtos in natura têm melhor qualidade, sem pensar que isso implica trabalho adicional com custo de mão-de-obra e realização de atividades danosas.

Outra limitação presente no HU é a questão das compras, a qual precisaria ser mais dirigida. Isso não é possível tendo limitações legais; as compras são realizadas por meio de licitações, aonde a escolha é por preço.

\section{Grau de apoio da superintendência aos projetos de ergonomia em geral}

Ao projeto plurianual de ergonomia foi dada a máxima prioridade possível, mas não tendo os departamentos de $\mathrm{RH}$ e do SESMT dentro do hospital (os quais ficam somente no nível da inteira universidade), não foi possível introduzir uma ação dirigida. Como estes departamentos não devem obediência ao HU, eles trabalham separadamente e não tem grandes responsabilidades sobre o que fazem, podendo 
participar ou não dos projetos internos de melhoria. Estes dificilmente alinham as próprias políticas àquelas necessárias para 0 hospital, podendo ocasionar comprometimentos no bom funcionamento do mesmo, como por exemplo, possibilitando que pessoas aposentadas continuem trabalhando. Além do mais o reitor exerce grande influência, podendo até barrar a contratação de pessoas no HUUSP, mesmo não tendo um controle sobre as necessidades locais.

Existem então limitações organizativas, sendo que o superintendente não pode ter um papel estratégico sem ter poder, sobretudo para gerenciar pessoas. Ele não consegue mudar o contrato de trabalho por inserir incentivos de produtividade, ter uma política de corte ou de admissão do pessoal de acordo com o orçamento. Além disso, existe um forte freio para a terceirização. Como o hospital não tem a governabilidade dos recursos humanos, tudo aquilo que é feito, compreendidas as ações ergonômicas, é apoiado apenas pela superintendência, não conseguindo se inserir numa política mais atuante.

Não adianta propor soluções atrativas se não existe a capacidade de implementálas. Antes de programar políticas ergonômicas estruturadas é necessário ter os meios para conseguir gerenciá-las. O primeiro grande objetivo da superintendência foi então conseguir sensibilizar as chefias para melhorar a própria liderança (através de algum curso interno). Existem dificuldades externas que não propiciam uma política estruturada para introduzir ações que melhorem a saúde dos trabalhadores. O NSS, por exemplo, nos últimos oito anos mudou continuamente as suas políticas. O sindicado ainda não compreende que não deve monetizar a saúde e a vida do trabalhador exigindo adicionais de insalubridade, mas ao contrário obrigando que todos os ambientes sejam saudáveis. .

\section{Sobre o GTC}

Devido à existência de limitações este não foi um projeto prioritário. Muitos aspectos deram certos, mas existem coisas que acabam com qualquer projeto; no hospital, em 2010, houve 42 pessoas na enfermagem a menos (em comparação com o quadro normal), sendo que as contratações foram desbloqueadas no último período depois de um ano. Tendo 42 funcionários a menos e não havendo reposição, qualquer política de ergonomia e melhoria de processo não tem condições de ser 
aplicada. Com tamanha falta de funcionários ou se trabalha menos, ou deixa-se de executar algumas tarefas, como estudar e alterar processos. Ou coloca-se um número de funcionários que consiga suprir tantas vagas vazias, ou qualquer inovação proposta não oferecerá impacto algum.

Quando se cria esta instabilidade sem saber se haverá reposição, qualquer coisa que se queira fazer perde o sentido. A disciplina interna cai já que o funcionário percebe que, devido à ausência de reposições, a chance de ser repreendido ou demitido se reduz, então diminui também o nível de comprometimento. Ele tende a fazer, mas fica desmotivado. As pessoas precisam sentir consistência por parte do empregador para ficarem motivadas, não acontecendo isso, falar sobre implementar um trabalho muito bom para as condições de trabalho fica para eles muito aleatório e o processo não entra. Na situação do HU-USP a reposição é fundamental, é a premissa para os funcionários, só depois chega o resto.

\section{Sobre o CM}

Este comitê consegue existir apenas com a superintendência tendo governabilidade. O CM é importante, mas precisa de pessoas especializadas, precisa de uma área física de RH e um SESMT do HU para conseguir entrar nos planos estratégicos. É inútil fazer grandes planos e maravilhas se não existem bases: conseguir uma estrutura de RH no HU-USP é então prioritário e chega antes de qualquer outra coisa. Toda a empresa racionaliza processos, elimina postos de trabalhos e ganha produtividade. Em um hospital, essa cadeia administrativa não ocorre.

\section{4 - Envolvimento dos trabalhadores no processo de melhoria na organização em nível estratégico (aplicação na seção das compras) - a questão das compras no HU-USP.}

Um dos eixos propostos na fase inicial para o desenvolvimento do $\mathrm{CM}$ foi a adequação do processo de compras para considerar, além de aspectos técnicos, também os aspectos ergonômicos na aquisição de materiais e equipamentos. 
Observações gerais e trabalhos de AET concluídos em algumas das seções mais críticas deixaram claro para o pesquisador esta falha na gestão hospitalar. Boa parte dos equipamentos de trabalho presentes nos departamentos não é adequada para proporcionar boas condições de trabalho, sobretudo os mais antigos e ainda não trocados desde a inauguração do hospital.

O HU-USP, por ser uma instituição pública, tem várias limitações, seja no processo técnico para adquirir material, precisando justificar cada investimento e submetendose à legislação em matéria, seja na própria organização, muito difícil de ser adaptada a esta necessidade, não podendo no instante introduzir um departamento ou algum profissional com competência técnica para aumentar o sucesso das compras.

Já foram realizados alguns trabalhos acadêmicos (MITSUISHI, 2009) discutindo a necessidade de proporcionar um maior cuidado na saúde do trabalhador no ato da compra, mas as poucas ações práticas introduzidas foram todas aplicadas por departamentos delimitados. Estes estudos, junto à introdução na instituição de outras pesquisas de ergonomia, aumentaram a sensibilização dos trabalhadores em introduzir ou embutir parâmetros ergonômicos na compra de novos equipamentos, mas mesmo assim a situação é ainda muito incipiente

No anexo G podemos conferir como atualmente é gerenciado o processo de compras no HU-USP e as dificuldades que o processo de licitação traz à instituição para a inclusão de aspectos de comparação ao ato da compra.

\subsection{1 - Entrevista com os gestores sobre ergonomia ligada às compras}

Conhecer o processo técnico de compra não foi suficiente para que o pesquisador entendesse aonde agir, sendo que atualmente a responsabilidade por pedir materiais e equipamentos é deixada aos chefes e aos responsáveis de compras das áreas. Para tal explicação foi necessária a execução de entrevistas qualitativas com os gestores do hospital, para entender os problemas e o estado as is no local. A entrevista com os gerentes foi necessária devido à sua posição no processo de compra do hospital: por um lado, observar as problemáticas operativas e, por outro, são eles que preenchem as "Requisições de compra" buscando solucionar as 
necessidades da própria área. Para o interesse da presente dissertação são reportados abaixo exclusivamente os dados da entrevista, os quais permitirão ampliar a discussão sobre a temática da emancipação do trabalhador.

\section{Problemas no trabalho com equipamentos.}

As questões da entrevista com todos os gerentes do HU-USP ajudaram a compilar uma lista que permitiu mapear as principais dificuldades presentes no hospital. Entre os agrupamentos feitos, as dificuldades devidas a equipamentos inadequados são aquelas que podem ser relacionadas mais proximamente ao problema de compras. Não ter equipamentos eficientes no próprio lugar de trabalho significa não conseguir comprar o requerido, ou obter através das compras equipamentos que não estejam conforme o esperado. Como apresentado na ilustração 9, foi coletado que menos da metade dos entrevistados, ou seja, 19 deles (42\%), não relataram problemas sobre equipamentos inadequados.

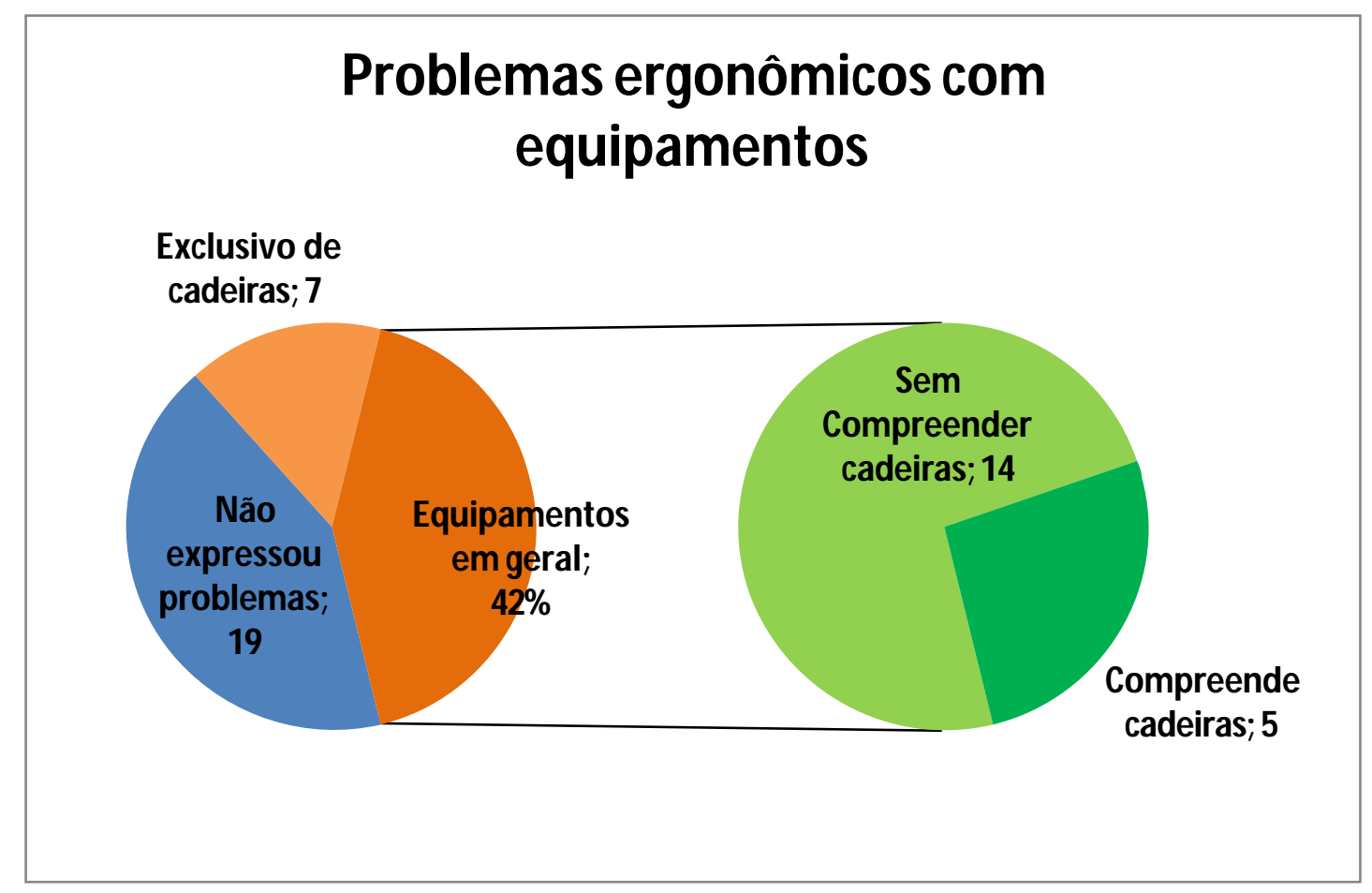

llustração 9 - Problemas ergonômicos com equipamentos.

Fonte: Elaboração própria a partir dos dados de pesquisa de campo.

Levantamos como causa principal de tal dado o fato que somente nos últimos anos começou-se a investir na introdução de equipamentos que possam permitir 
condições adequadas no trabalho, mas existem muitos equipamentos que nunca foram substituídos desde a inauguração do hospital, ocorrida há 29 anos, período que não era ainda presente uma preocupação específica com o bem estar dos funcionários.

Este dado pode contextualizar a dimensão da problemática, mas nem tudo pode ser responsabilizado por uma gestão inadequada das compras. Tal finalidade foi levantada entre os gestores que já realizaram compras que não atenderam as suas necessidade, ou que se revelaram ruins para as condições de trabalho dos funcionários. Os resultados são apresentados na ilustração 10.

O dado mais importante que podemos extrair é que a quantidade de gestores que já tiveram problemas com compras inadequadas é muito elevada: o objetivo da instituição seria então zerar este número. Por causa deste grande número de insucessos, existem trabalhadores que estão atualmente utilizando equipamentos velhos, preferindo-os aos recém comprados. Uma melhoria do sucesso na compra, como esperado no eixo do CM do HU-USP em análise, teria assim um impacto muito significativo. O problema então não é exclusivo do processo de compras no HUUSP, mas também sobre o conhecimento de quem formula a "Requisições de compra".

\section{Presencia de compras que deram problemas}

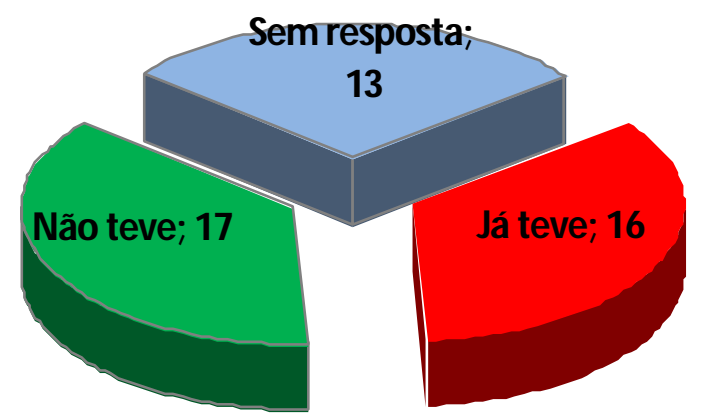

llustração 10 - Presencia de compras que deram problemas.

Fonte: Elaboração própria a partir dos dados de pesquisa de campo. 


\section{Cuidado com a temática ergonômica no momento da requisição de compras}

Levantado a problemática, buscou-se conhecer a relação dos entrevistados com o cuidado sobre a saúde do trabalhador da própria área de atuação na hora de compilar as "Requisições de compra". Para alcançar tal análise foram definidos cinco possíveis tipos de cuidado:

- Delegado: este é o caso de chefias que delegam totalmente a compilação da "Requisição de compra" para um responsável. Em tal sentido, eles não se preocupam diretamente se as compras consideram os aspectos ergonômicos. Nestes casos existe total confiança no trabalho de compras delegado.

- Ausente: o gestor não se preocupa com os aspectos ergonômicos; estes não são elementos considerados numa eventual compra.

- Implícito: na hora da compra o aspecto técnico (adequação para atender e resolver as necessidades do usuário do serviço) é prioritário para a escolha do material (ou equipamento), mas partindo dos próprios conhecimentos (geralmente limitados) se propõe a compra de materiais que não sejam nocivos às condições de trabalho dos próprios funcionários.

- Presente: ao fazer requisições de compra, o gestor considera tanto os aspectos técnicos como os aspectos ergonômicos. Procura-se indagar se o material (ou equipamento) é adequado ao trabalho dos funcionários.

- Proativo: é o caso de gestores que consideram o aspecto ergonômico como prioritário. Neste caso, além de ter presente a preocupação, se busca proativamente por soluções, muitas vezes também originais, para resolver completamente problemas de saúde dos próprios postos de trabalho.

Uma empresa que quer cuidar dos próprios trabalhadores precisaria ter um cuidado completamente proativo. Mesmo assim, ter pessoas com um cuidado presente sobre aspectos ergonômicos é positivo. Ter cuidado implícito não pode ser considerado positivo, sendo que os conhecimentos iniciais das pessoas sobre a ergonomia é geralmente limitada, mas pode ser considerado razoável, o esperado médio numa empresa que nunca teve interesse em melhorar as próprias compras sob o aspecto ergonômico. 
Os resultados iniciais relativos aos gestores do HU-USP (ilustração 11) descrevem uma situação inicial que pode ser considerada positiva. Apenas cinco pessoas relatam não ter este tipo de cuidado, enquanto quase a metade dos entrevistados (22) tem um cuidado pelo menos ativo. Nas entrevistas fica claro como alguns gestores reconhecem que nos últimos tempos, diferentemente do passado, são considerados aspectos ergonômicos na hora da compra, existindo um novo olhar. A instituição também esta desenvolvendo um papel importante no que se refere a cuidar da saúde do trabalhador. Embora isso, falta ainda que todos os gerentes priorizem também a saúde do funcionário na hora da compra.

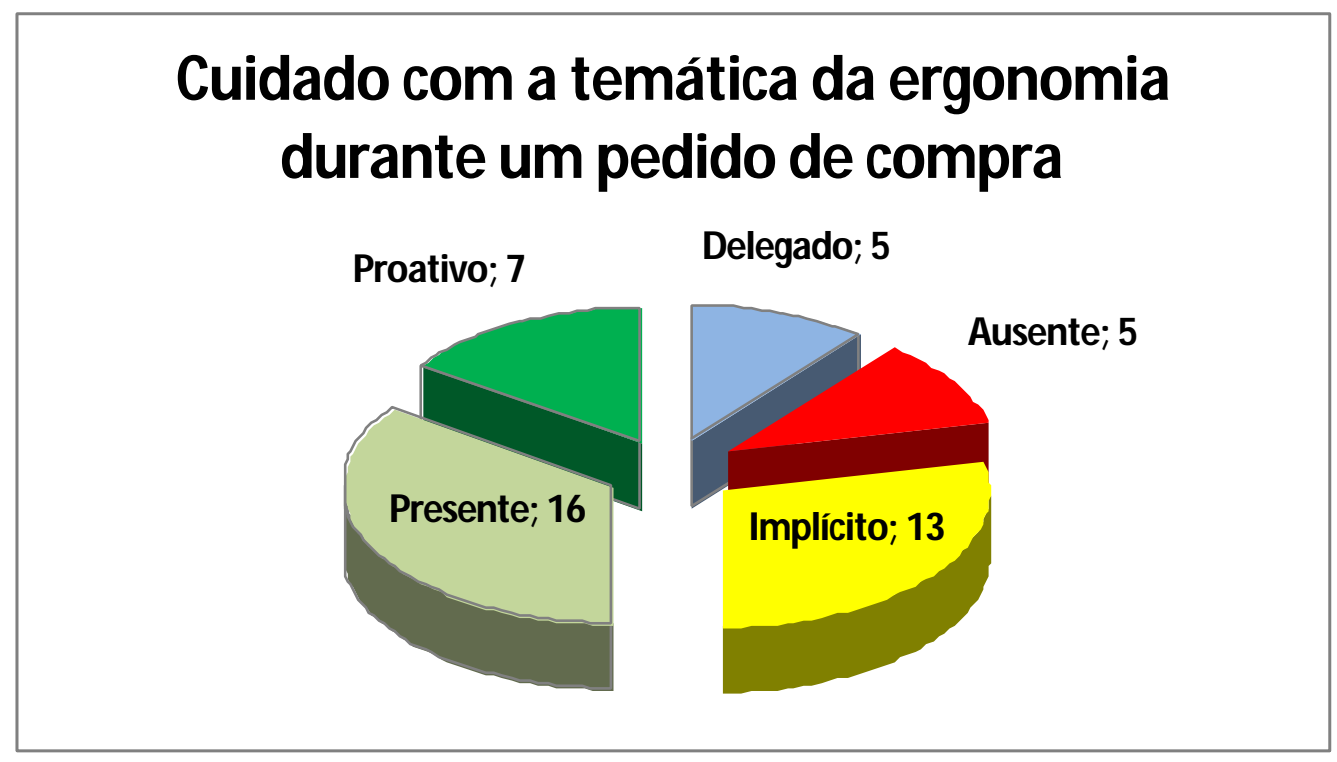

Ilustração 11 - Cuidado com a temática da ergonomia durante um pedido de compra.

Fonte: Elaboração própria a partir dos dados de pesquisa de campo.

Este resultado é fortemente influenciado pelos projetos de ergonomia que ocorreram no hospital. Vários trabalhos de AET e GTC desenvolvidos nos últimos anos aumentaram o interesse dos gestores na temática da ergonomia. Isso é confirmado pela tabela 18, na qual foram divididos os tipos de cuidados por grupos de gestores.

Para tal análise foram formados os grupos da Enfermagem e Médico que agregam os gerentes das relativas áreas, o grupo Outros (1) com as chefias do SAME, Nutrição e Dietética, Higienização especializada e Compras e o grupo Outros (2) com os gestores remanescentes. Excluindo o cuidado Delegado, podemos extrair como os grupos da Enfermagem e Outros (1) tiveram um cuidado médio mais ativo: os principais projetos de ergonomia foram desenvolvidos entre os gerentes destes 
dois grupos. Os médicos, embora os próprios conhecimentos profissionais se coloquem sucessivamente, demonstram um "cuidado em aspectos ergonômicos" melhor que Outros (2)

\begin{tabular}{|c|c|c|c|c|c|}
\cline { 2 - 6 } \multicolumn{1}{c|}{} & Enfermagem & Medico & Outros (1) & Outros (2) & \multicolumn{1}{c|}{} \\
\hline Delegado & 4 & 0 & 0 & 1 & 5 \\
\hline Ausente & 0 & 2 & 1 & 2 & 5 \\
\hline Implícito & 5 & 3 & 0 & 5 & 13 \\
\hline Presente & 10 & 1 & 4 & 1 & 16 \\
\hline Proativo & 2 & 2 & 2 & 1 & 7 \\
\hline & 21 & 8 & 7 & 10 & $\mathbf{4 6}$ \\
\hline
\end{tabular}

Tabela 18 - Tipo de cuidado em assuntos ergonômicos em compras, por grupos de gestores.

Fonte: Elaboração própria a partir dos dados de pesquisa de campo.

Junto à resposta do tipo de cuidado, muitos entrevistados comentaram sobre a capacidade pessoal de propor a compra de materiais e equipamentos ergonomicamente corretos. Os resultados (ilustração 12) esclarecem como a maioria dos gerentes não conseguiria escolher o que realmente seria ideal para o bem-estar dos próprios funcionários, mas que precisariam de ajuda externa.

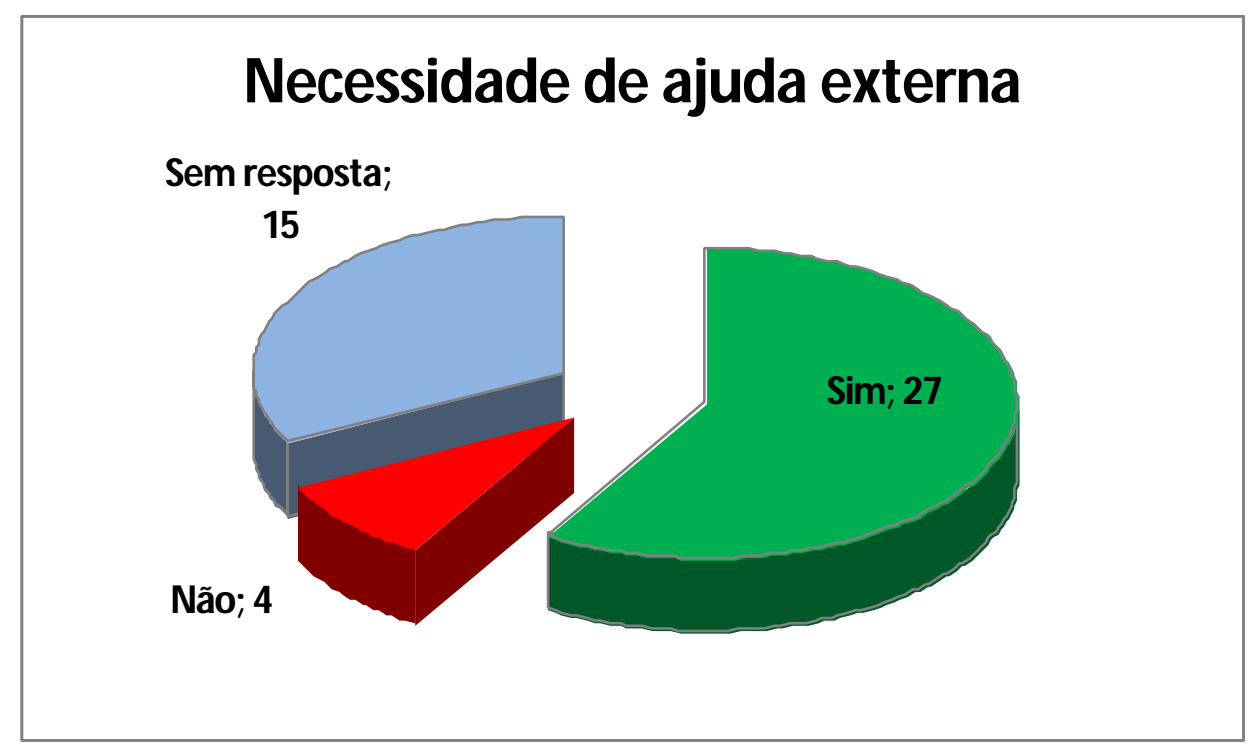

llustração 12 - Necessidade de ajuda externa em considerar aspectos ergonômicos nas compra.

Fonte: Elaboração própria a partir dos dados de pesquisa de campo.

$\mathrm{Na}$ análise sobre os chefes que responderam de necessitar de ajuda externa, poucos indicaram como solução o envolvimento de uma figura profissional já 
presente e atuante no hospital (ilustração 13). Não houve uma descrição detalhada, mas a maioria dos entrevistados gostaria da presença de uma nova figura profissional no HU-USP com conhecimentos técnicos e específicos em ergonomia. Traduzindo, eles acreditam que atualmente no hospital não seria possível contemplar completamente o aspecto ergonômico nas compras.

Médicos e enfermeiros já têm o suporte de uma enfermeira responsável pelas compras que dedica completamente o próprio trabalho em solucionar problemas e melhorar tal processo. As sete enfermeiras e o médico que comentaram sobre esta figura profissional concordaram em afirmar que ela desenvolve um papel muito importante para estes dois departamentos, sendo que anteriormente as compras estavam muito diluídas, e hoje a especialização desta atividade trouxe benefícios generalizados. O limite desta figura, porém, é o fato de ser realizado por uma enfermeira ótima para especificações técnicas e conhecimentos sobre a funcionalidade dos equipamentos, mas menos direcionada aos aspectos ergonômicos (anexo F, fala 18).

\section{Quem poderia dar suporte?}

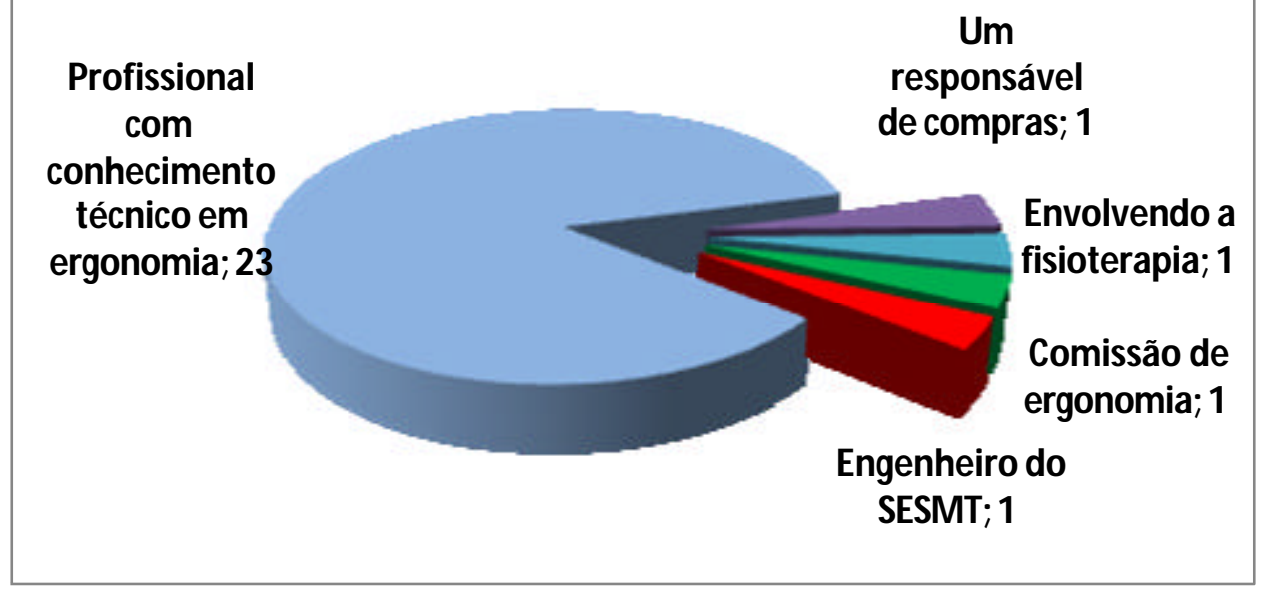

llustração 13 - Respostas de quem poderia dar suporte por questões ergonômicas na hora da compra.

Fonte: Elaboração própria a partir dos dados de pesquisa de campo.

Relacionando as respostas sobre problemas nas compras e sobre a necessidade de ajuda, junto ao tipo de cuidado, foi construída a tabela 19. 


\begin{tabular}{|c|c|c|c|c|c|c|c|}
\cline { 3 - 9 } \multicolumn{2}{c}{} & \multicolumn{4}{c|}{ Teve problemas? } & \multicolumn{3}{c|}{ Ajuda externa? } \\
\hline Cuidado ergonomico sobre as compras & Sim & Nao & Sem R. & Sim & Nao & Sem R. \\
\hline Delegado & 5 & 3 & 1 & 1 & 3 & 0 & 2 \\
\hline Ausente & 5 & 0 & 3 & 2 & 1 & 0 & 4 \\
\hline Implícito & 13 & 4 & 6 & 3 & 8 & 0 & 5 \\
\hline Presente & 16 & 6 & 0 & 10 & 15 & 0 & 1 \\
\hline Proativo & 7 & 0 & 7 & 0 & 0 & 4 & 3 \\
\hline & 46 & 13 & 17 & 16 & 27 & 4 & 15 \\
\hline
\end{tabular}

Tabela 19 - Relação entre tipo de cuidado ergonômico, presença de problemas sobre a saúde do trabalhador e necessidade de ajuda externa na hora da compra de equipamentos.

Fonte: Elaboração própria a partir dos dados de pesquisa de campo.

Os que não têm cuidado em geral nunca tiveram problemas com compras inadequadas. Partindo de tal situação, eles não se questionam sobre temática nem sobre a necessidade de uma ajuda externa para melhorar as próprias compras. Os gestores com cuidado presente, por outro, lado já tiveram problemas, o que os levou a se interessarem pela temática ativamente e a perceber que seria uma coisa melhor resolvida com uma ajuda externa. Enquanto os entrevistados com cuidado implícito se encontram entre as duas posições antecedentemente descritas, quem tem cuidado proativo nunca teve problemas. Estes últimos antecipam as problemáticas e escolhem cuidadosamente as compras com sucesso, não precisando assim de uma ajuda externa.

\section{Problemas ligados ao conforto na compra de equipamentos}

A entrevista aprofundourse sobre esta temática tentando localizar as raízes de tal problema sob o olhar de quem está presente nas áreas e conhece diretamente os problemas. Durante as verbalizações dos entrevistados surgiram muitos pareceres sobre o motivo de uma limitação geral em considerar aspectos ergonômicos durante as compras. Foram levantadas 11 macro-motivações (ilustração 14):

- Falta de conhecimento ergonômico: embora haja preocupação, boa parte dos gestores acredita não ter competência o bastante em escolher o equipamento mais adequado, não conseguindo adicionar esta atenção no processo de compra. Durante as entrevistas os gestores reconhecem sua maior habilidade, domínio técnico, e científico em analisar equipamentos relacionados ao âmbito da sua 
atuação, e este lado muitas vezes é prioritário, (ou mesmo o único) a ser considerado.

A falta de conhecimento ergonômico é a principal causa de uma porcentagem tão alta de gestores que gostariam ser auxiliados por um profissional externo nas questões ergonômicas.

- Especificações: Existe uma dificuldade generalizada em traduzir as próprias necessidades ergonômicas em especificações (anexo F, falas 19). Saber especificar o produto requerido e com bom nível de detalhe é indispensável ao sucesso da compra. São tais especificações que se não atendidas desqualificam do processo licitatório, eventuais propostas com materiais inadequados. Este problema é estreitamente ligado ao problema descrito antecedentemente de falta de conhecimento em matéria ergonômica: sem noções adequadas é impossível a especificação em um nível apropriado.

Nas entrevistas não existem queixas sobre o trabalho do setor das Compras neste aspecto: todos reconhecem como as especificações dadas sempre foram respeitadas durante a compra.

Um dos problemas levantados sobre a licitação de material e equipamentos de largo consumo é que as compras são agregadas por diversos setores, podendo acontecer que quem faz pedidos e solicitações nem sempre é quem utiliza o material ou equipamento.

- Aspecto cultural: Alguns gestores do HU-USP afirmam que uma das causas da baixa consideração dos aspectos de melhoria deve-se ao aspecto cultural, aonde não existe muita iniciativa em buscar soluções (anexo F, falas 20), nem um cuidado estruturado da organização em compras focalizadas no funcionário.

- Testes não suficientes: Antes da compra os materiais e os equipamentos são testados, sendo que aqueles avaliados positivamente são efetivamente pedidos. Este cuidado nem sempre leva a resultados positivos: pode acontecer que no uso sucessivo se perceba algum defeito ou inconformidade, então material não é mais usado. Muitas chefias utilizam esta fase para testar e embutir a avaliação ergonômica à compra, mas este tempo pode não ser suficiente (anexo $\mathrm{F}$, falas 21).

- Demora da compra e prioridades: O processo de licitação é considerado pela a maioria dos entrevistados como demorado. Isso, em princípio, não é visto 
negativamente; todos concordam que o tempo atual é efetivamente o necessário e justo, considerando como a licitação acrescenta muitos procedimentos não presentes, por exemplo, numa empresa particular. Um dos chefes com cuidado proativo descreve esta demora positivamente: "Demora porque esta tendo muito cuidado. Quando tenho urgência chegam". O aspecto negativo é que tanta demora leva as pessoas a serem mais imediatistas. Um exemplo significativo pode ser encontrado na fala 22 no anexo $\mathrm{F}$.

As prioridades de compras, definidas pelo grupo de investimentos, causam também problemas. Mesmo existindo um plano quadrienal, a prioridade de compra de determinados equipamentos pode mudar anualmente. Sobretudo em áreas menos consideradas, as quais não envolvem problemas específicos sobre a saúde dos pacientes, vêem as próprias compras sendo postergadas ano a ano, desmotivando e obrigando a soluções mais imediatas e não ótimas.

- Obstáculos no processo de compra: O processo de compra compreende muitos passos, e isso complica ulteriormente a situação para quem quer adquirir produtos prevendo as necessidades ergonômicas Um exemplo levantado é a necessidade de passar a "Requisição de compra" para o NUGEM. Este órgão pode reprovar pedidos simplesmente partindo do formulário, o qual nem sempre reporta a total realidade.

Muitos atores do processo não compreendem as necessidades, mesmo ergonômicas, dos setores, e as requisições podem parar.

- População média: Em uma entrevista foi explicado como durante a compra não são consideradas as particularidades de cada posto de trabalho, mas é vista apenas a média da população do hospital. Disso deriva o fato que normalmente a compra prioriza a aquisição de equipamentos para a população média, que nem sempre cuida das particularidades físicas de algumas pessoas, com uma estatura física, por exemplo, extremamente baixa ou alta.

- Mercado: Foi afirmado que as especificações do mercado nem sempre não atendem as necessidades, mas existe também a crença de alguns que as opções no mercado são limitadas (anexo F, falas 23). Além disso, podem existir empresas que produzem produtos com ótimos parâmetros ergonômicos, mas que não entram no processo de licitação porque este é muito complexo e não vantajoso para elas. 
- Falta de tempo: Existe a dificuldade por parte de alguns gestores em sair da própria rotina de trabalho para observar os detalhes e buscar no mercado equipamentos que permitam solucionar as dificuldades ergonômicas.

- Externo ao processo de compra: Existem compras inviáveis por alguma variável externa (como exemplo, a necessidade de realizar antecedentemente uma reforma do lugar de trabalho) ou compras que seriam ótimas na teoria, mas que precisam ser readaptadas por forças maiores, e que na prática não resolvem problemas ligados ao conforto (por exemplo, se num serviço assistencial subestimado torna-se necessário transformar ótimas macas em leitos)

- Econômico: Alguns entrevistados acreditam que existem dificuldades de verba e que o equipamento ergonomicamente melhor é o mais caro, inviabilizando então a sua compra. A limitação econômica leva à reutilização de alguns equipamentos, sobretudo de escritório (mesas e cadeiras) e informáticos. Os últimos, em particular, são um problema por serem recursos que muitas vezes chegam nas áreas de destino já ineficientes.

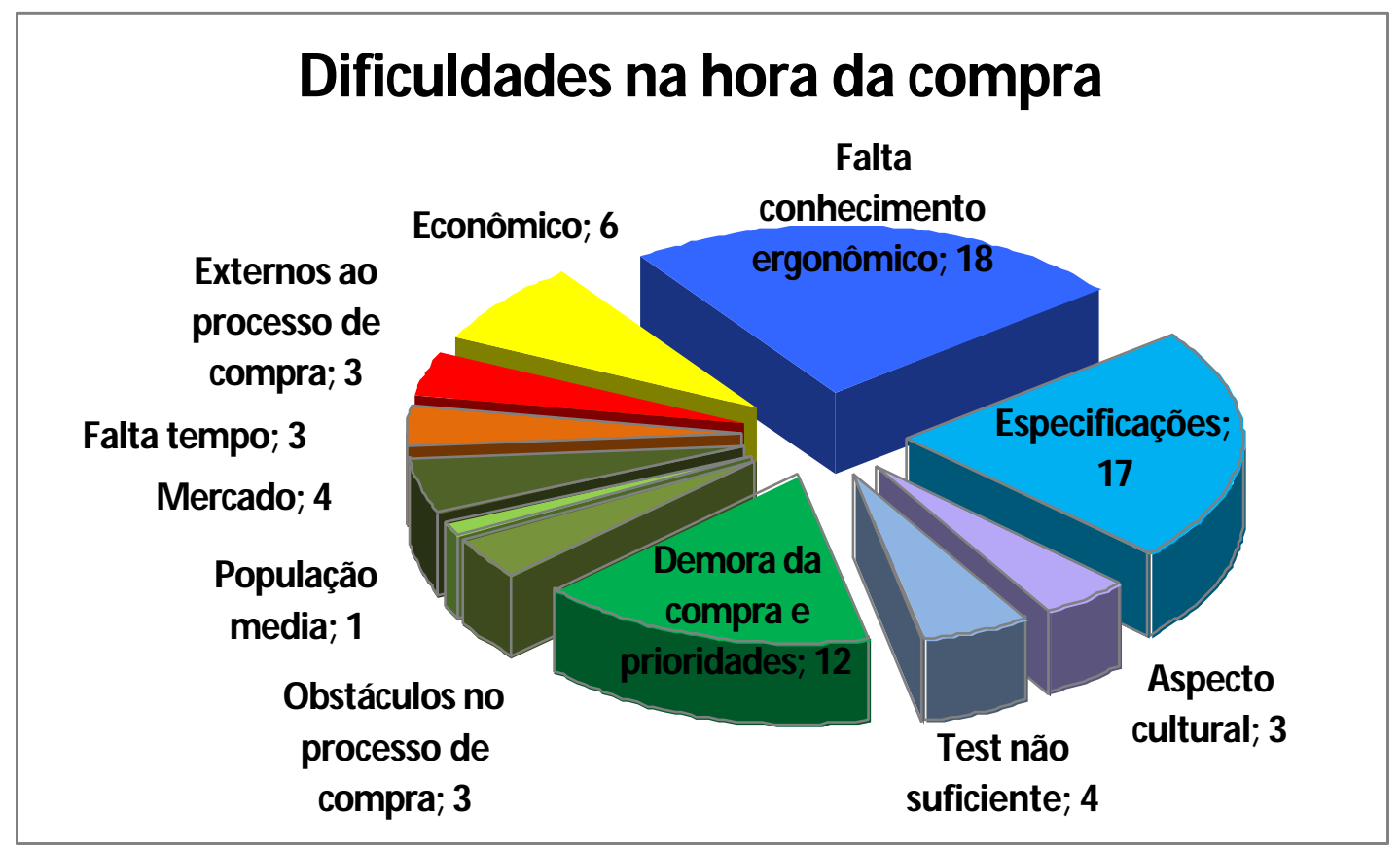

llustração 14 - Dificuldades dos gestores na hora da compra de equipamentos.

Fonte: Elaboração própria a partir dos dados de pesquisa de campo.

Com a ajuda da ilustração 14 fica então claro como os mesmos gestores indica a própria falta de conhecimento sobre a temática da ergonomia como a maior causa 
da presença de tantos problemas com a compra de equipamentos. Esta dificuldade pode ser adicionada às respostas dadas sobre "Especificações", "Aspecto cultural", "Teste não suficiente", as quais se assemelham por poderem ser resolvidas através da maior formação dos gerentes. Esta falta é a maior causa raiz, com 42 respostas sobre 74. Outra causa raiz é o conjunto de "Demora da compra e prioridades", "Obstáculos no processo de compra", "População Média" e "Mercado" os quais dificilmente podem ser mudados devido ao do processo licitatório.

Por outro lado, "Falta de tempo" e "Externos ao processo de compra" podem ser melhorados, se modificada alguma estratégia da organização. Para alterarmos estes quesitos seriam necessários estudos específicos. Por última, a "Dificuldade Econômica" pode ser considerada como um vínculo, necessitando também de outra análise mais aprofundada

Falta de conhecimento ergonômico, dificuldades em especificar adequadamente, e falta de tempo são problemas de responsabilidade direta dos gestores. Buscando as respostas dadas sobre estas dificuldades, e considerando exclusivamente aquelas informadas individualmente (e não com referência na impressão geral sobre os outros atores da organização) a tabela 20 as relaciona com o tipo de cuidado declarado.

\begin{tabular}{c|c|c|c|c|c|c|c|} 
Tipo cuidado & Total & \multicolumn{2}{|c|}{ Falta conh. erg. } & \multicolumn{2}{|c|}{ Especificações } & \multicolumn{2}{|c|}{ Falta tempo } \\
\hline Delegado & 5 & 1 & $20 \%$ & 1 & $20 \%$ & 0 & $0 \%$ \\
\hline Ausente & 5 & 3 & $60 \%$ & 2 & $40 \%$ & 0 & $0 \%$ \\
\hline Implicito & 13 & 5 & $38 \%$ & 3 & $23 \%$ & 0 & $0 \%$ \\
\hline Presente & 16 & 8 & $50 \%$ & 5 & $25 \%$ & 4 & $25 \%$ \\
\hline Proativo & 7 & 0 & $0 \%$ & 0 & $0 \%$ & 0 & $0 \%$ \\
\hline Total geral & 46 & 17 & $37 \%$ & 11 & $\mathbf{2 3 , 9} \%$ & 4 & $\mathbf{8 , 7} \%$ \\
\hline
\end{tabular}

Tabela 20 - Relação ente tipo de cuidado ergonômico e quem respondeu da existência de problemas na falta de conhecimento ergonômico, no especificar e na falta de tempo.

Fonte: Elaboração própria a partir dos dados de pesquisa de campo.

Sendo uma entrevista livre, e tendo a possibilidade que alguma pessoa não tenhamse exprimido sobre estas temáticas, não é possível obter conclusões muito comparativas entre os números coletado. Fica claro, porém, como os chefes com cuidado proativo não apresentaram nenhuma dificuldade pessoal. Nas suas entrevistas fica claro como eles vão buscando os conhecimentos, dedicando tempo 
a este assunto, e existe muito cuidado para que as especificações técnicas sejam as mais detalhadas possíveis para comprar o produto mais funcional tecnicamente e que proporcione as melhores condições de trabalho possíveis. Isso justifica o porquê da ausência de casos de compras inadequadas no passado.

Entrevistas pessoais do pesquisador com a seção de compras e com a seção financeira do hospital ajudaram no entendimento de que existem dois elementos na lista de problemáticas que podem ser considerados falsas crenças:

- No problema "econômico" existem sim limitações de verba, mas não existem dificuldades em justificar necessidades ergonômicas. Com boa argumentação e com especificações bem detalhadas são comprados os equipamentos requisitados. A única limitação é não poder escolher um produto específico de uma marca específica.

- O mercado não é tão limitado como muitos crêem. Devido à grande variedade de produtos, uma busca mais detalhada no mercado permite encontrar muitas soluções além daquelas imaginadas.

Relacionando estas respostas com o tipo de cuidado (tabela 21), é interessante notar que quanto menor é o cuidado e o interesse em questões ergonômicas, maior é a presença de falsas crenças.

\begin{tabular}{|c|c|c|c|c|c|}
\hline Tipo cuidado & Total & \multicolumn{2}{|c|}{ Econômico } & \multicolumn{2}{c|}{ Mercado } \\
\hline Delegado & 5 & 0 & $0 \%$ & 0 & $0 \%$ \\
\hline Ausente & 5 & 0 & $0 \%$ & 2 & $40 \%$ \\
\hline Implícito & 13 & 1 & $8 \%$ & 0 & $0 \%$ \\
\hline Presente & 16 & 1 & $6 \%$ & 0 & $0 \%$ \\
\hline Proativo & 7 & 0 & $0 \%$ & 0 & $0 \%$ \\
\hline Total geral & $\mathbf{4 6}$ & $\mathbf{2}$ & $\mathbf{4 , 3} \%$ & $\mathbf{2}$ & $\mathbf{4 , 3} \%$ \\
\hline
\end{tabular}

Tabela 21 - Relação ente tipo de cuidado ergonômico e quem respondeu da existência de problemas econômicos e no mercado na hora da compra de equipamentos.

Fonte: Elaboração própria a partir dos dados de pesquisa de campo.

É muito importante investir na educação, principalmente daqueles atores que podem em disseminar conceitos ergonômicos no hospital. Partindo de uma entrevista feita com o gestor de um setor que se encontra numa posição intermediária entre as 
compras e as outras seções do hospital, e que muitas vezes auxilia nos pedidos de compra, confirmamos a presença de falsas crenças ou falta de cuidado ergonômico.

\section{Envolvimento de funcionários da área operativa}

Um aspecto interessante levantado durante as entrevistas é o envolvimento nas decisões de compras dos próprios trabalhadores da área operativa. Estes são considerados os maiores portadores do conhecimento relativo ao trabalho (mais que os chefes), mas foi geral a afirmação de que estes, sem o acompanhamento de um profissional, nem sempre conseguem trazer sugestões corretas (anexo F, falas 24). As duas seguintes verbalizações levantam dois exemplos:

\subsection{2 - Envolvimento dos coparticipantes do HU-USP na resolução do eixo da aquisição de materiais, equipamentos, sistemas de informação e serviços}

Na experiência prática de resolução do segundo ciclo de pesquisa-ação, o autor da dissertação teve a possibilidade de contato com diferentes atores do hospital. Um dado interessante a ser descrito foi o grau de envolvimento de tais pessoas:

- Assessora da Superintendência (diferente daquela de contato): além de ser o primeiro contato, foi à pessoa que levantou a problemática do hospital ao pesquisador. Numa única reunião foram mostrados os pedidos ainda não processados (alguns com já dois anos) e a dificuldade em obter compras que suprissem totalmente as necessidades. O principal problema observado foi responder às necessidades específicas de equipamentos comuns (como cadeiras) e a impossibilidade de fazer pedidos personalizados (por causa das licitações). 0 envolvimento desta assessora na resolução do eixo foi de suporte (permitiu o contato com os outros participantes do eixo, entendendo a importância estratégica que uma solução teria trazido), mas passivo (deixando que a equipe resolvesse tudo sozinha).

- Chefe da seção das Compras do HU-USP: foi contatado sucessivamente junto à seção dos materiais da enfermagem, e mesmo sendo responsável exclusivamente pelo processo administrativo de compras (transformar as requisições de compras em 
compras reais) ajudou e disponibilizou muito tempo em reuniões para resolver o problema. O envolvimento foi totalmente ativo e ajudou o autor a levantar todas as informações necessárias ao estudo.

- Chefe da seção dos materiais da Enfermagem: interessada na melhoria real de tal eixo (sendo a responsável pelas compras de toda a enfermagem e da área médica) teve um envolvimento semelhante ao chefe da seção de compras, e disponibilizou o seu tempo para todas as necessidades envolvidas na resolução do problema.

- Chefe da Fisioterapia: foi contatada sucessivamente aos demais por já ter tentado resolver a problemática anteriormente, e por isso foi uma ótima fonte para levantar informações. Um ponto claro desde o início é que, se necessário, o contato teria agido pessoalmente em algumas questões, mas apenas com suporte externo. $\mathrm{O}$ seu envolvimento foi totalmente ativo, sendo que já houve também um envolvimento proativo (com as informações até então obtidas, mesmo não cuidando do aspecto ergonômico no hospital) que não foi posto em prática, já que a questão ergonômica no hospital não tinha prioridade estratégica por parte da Superintendência. 


\section{6 - DISCUSSÃO}

Com esta seção não pretendemos entregar um diagnóstico da pesquisa ação, nem as sugestões de melhoria sobre o trajeto de ações ergonômicas desenvolvidas no HU-USP, conseqüentes das entrevistas. Neste capítulo, os resultados alcançados antecedentemente são reunidos e analisados a partir dos objetivos e das proposições iniciais. Para facilitar a leitura os sub-capítulos são divididos partindo dos objetivos; começando com o sub-objetivo geral, para passar sucessivamente aos dois principais da dissertação. A discussão se conclui com algumas considerações sobre o Comitê de Melhorias, meio organizacional de extrema importância.

\section{1 - Analise do sucesso ou insucesso dos projetos de ergonomia no HU-USP}

A seguir são apresentadas as três ações ergonômicas mais importantes desenvolvidas no HU-USP, analisadas segundo o grau de sucesso ou insucesso das mesmas. O sub-capítulo se conclui analisando o projeto como o conjunto de todas estas ações coordenadas.

\section{Comitê de melhorias (CM)}

O CM é uma aplicação da ergonomia com uma literatura que não pode ser considerada extensa, e sem uma metodologia de aplicação que seja unívoca (GUIMARÃES, 2000; OHCOW, 2001), sendo construído a partir das necessidades e das oportunidades especificas de cada situação de análise (SILVERSTEIN et al., 1991; NAGAMACHI, 1995; MOORE e GARG, 1998, ST-VINCENT, CHICOINE e BEAUGRAND, 1998; HAGG, 2003; TORMA-KRAJEWSKI et al., 2007; VILLENEUVE et al., 2007; ACOSTA e MORALES, 2008; NEUMANN, EKMAN e WINKEL., 2009). $\mathrm{Na}$ avaliação de tal comitê o autor quis trazer resultados, benefícios, e até limites, da aplicação específica no HU-USP.

Fazendo uma avaliação sobre os sucessos e insucessos alcançados por tal CM relacionando-os às oportunidades presentes no HU-USP, os resultados podem ser 
considerados positivos, sendo que na organização foram implantadas várias ações e melhorias de impacto não exclusivamente local, mas transversais a toda a organização, como descrito no capitulo dos resultados. Porém, com referência na visão inicial dos pesquisadores sobre o trajeto de ações ergonômicas desenvolvidas no HU-USP apresentada no terceiro capitulo, pouco foi alcançado, limitando sensivelmente os benefícios que o $\mathrm{CM}$ poderia ter trazido. Em particular, este meio organizacional mostrou pouca força de ação tanto na instituição como entre os próprios participantes, o que provocou a sua parada logo após o término da participação no projeto da assessor-coordenadora. A aprendizagem conseqüente a esta experiência mostra dois elementos fundamentais para o sucesso desta ação:

- A existência de apoio e comprometimento constante, desde o início do projeto, dos que têm poder de decisão na organização (TORMA-KRAJEWSKI et al., 2007; VILLENEUVE et al., 2007, NEUMANN, EKMAN e WINKEL., 2009). Para conseguir um crescente apoio e maior confiança da diretoria no HU-USP os pesquisadores desenvolveram várias ações com impacto positivo crescente, mas acredita-se que com uma maior propaganda dos resultados alcançados e uma avaliação prévia de custos e benefícios, como aconselhado por Hendrick (2003), o apoio ao CM teria sido maior.

- Pro atividade, uma postura dos participantes em direção à emancipação, para que estes possam expor as sugestões de melhoria e conseguir resolvê-las.

No caso do HU-USP o sucesso restringiu-se devido à limitação da contribuição positiva destes dois elementos:

- Por parte da direção da organização foi claro que existiam dificuldades para implementar a discussão da ergonomia em um nível estratégico. Existem bloqueios, por exemplo, como as responsabilidades legais derivadas do processo de compra através de licitações, aonde é preciso ainda construir uma prática mais apurada. Com a existência de grandes problemas no dia-dia, e sendo difícil uma gestão a médio e longo prazo, a diretoria, também no caso do $\mathrm{CM}$, limitou-se a dar um simples suporte delegando a coordenação das ações ergonômicas no HU-USP a uma assessora.

- Na postura dos participantes, partindo das entrevistas realizadas, foi claro como o grau de envolvimento geral foi baixo, sendo que nem todos conheciam os objetivos 
globais do CM, fazendo com que a visão futura sobre o mesmo fosse geral negativa. A freqüência das reuniões foi um indicador indireto disso; não existiu uma apropriação geral do CM como um espaço para a melhoria do próprio trabalho (e do trabalho em toda a instituição). Segundo o autor, o CM foi percebido, maiormente através de uma visão funcionalista, considerado um meio organizacional construído com a função de resolver problemas exclusivamente de cima para baixo. Houve, porém a confirmação da presença de sujeitos proativos no meio.

Excluindo os resultados alcançados com a presença ativa da equipe da Escola Politécnica, os outros resultados foram possibilitados quase que exclusivamente por parte das pessoas que, através da análise, foram definidas proativas (por exemplo, no suporte à implementação prática de parte dos diagnósticos dos trabalhos AET desenvolvidos no GTC, na construção da ferramenta da vigilância epidemiológica, e nas ações no eixo das políticas para trabalhadores com restrições e necessidades especiais).

\section{Grupo de Treinamento e Capacitação (GTC)}

O GTC é uma ação de ergonomia para a qual não encontramos uma literatura estruturada e uma metodologia de aplicação unívoca, sendo então construído como no caso do CM, partindo das necessidades e das oportunidades específicas de cada situação de análise. Com a exposição dos resultados de tal grupo, o autor quis entregar aos leitores os benefícios e os limites da aplicação específica no HU-USP.

Numa avaliação global os resultados finais alcançados no HU-USP podem ser considerados positivos, em particular por três motivações:

- A grande maioria dos participantes ampliou os próprios conhecimentos na temática da ergonomia,

- Os projetos práticos derivados dos estudos de AET nas nove áreas de estudo do hospital impulsionaram, através do $\mathrm{CM}$, a introdução de reformas físicas e melhorias de processos em diversos espaços do hospital.

- Embora tenha sido mostrado que os participantes dos cursos não foram grandes elementos ativos e multiplicadores dos conceitos ergonômicos no hospital, tais assuntos foram espalhados indiretamente a todos os chefes da instituição (alguns 
mais, outros menos) através da exposição dos casos de AET que tiveram maior sucesso. Por meio destas exposições foi permitindo alcançar o objetivo principal do curso.

Pontos positivos e limites do GTC foram já descritos a partir das entrevistas com os participantes no capítulo dos resultados, mas partindo de uma análise conjunta dos dados, grande parte da influência no grau de sucesso do mesmo deveu-se:

- Ao papel daqueles com poder de decisão no HU-USP em proporcionar as melhores condições para que os participantes tivessem total aproveitamento da proposta ergonômica. Mostrourse muito positivo possibilitar a dedicação de uma sexta-feira por mês ao GTC, embora tenha surgido dificuldade por parte dos gestores em lidar com um acúmulo de trabalho depois do curso. Dentro do HU-USP surgiu, sucessivamente, uma problemática: foram capacitadas pessoas para trazer amplos benefícios à organização, estas, porém não foram envolvidas em projetos de melhoria sucessivos, e partindo das expectativas criadas acabaram sentindo-se como que "abandonadas". Com um melhor gerenciamento por parte do topo da estrutura organizacional (e também dos pesquisadores) não teria ocorrido tal problema, e os benefícios da ação ergonômica poderiam ter sido muito maiores,

- Às expectativas dos participantes do curso, as quais precisam estar alinhadas com os "planos futuros" da instituição. Ter expectativas maiores provoca insatisfação e desmotivação. Ligado a tal aspecto, as pessoas devem que ser perfeitamente informadas sobre todos os detalhes, para que não haja incompreensões e frustrações.

- Ao grau de envolvimento e participação dos sujeitos que compõem o grupo. A voluntariedade na entrada do grupo é fundamental, sendo maior a possibilidade que os participantes ampliem os próprios conhecimentos e os apliquem no próprio trabalho. Foi demonstrado, porém, que aqueles que tiveram um grau de voluntariedade inicial mais alto expuseram pior avaliação do suporte da diretoria após o curso, ou seja, segundo o autor, as pessoas mais propensas a se emancipar podem se desiludir, tirando o potencial emancipador e possibilitando a entrada de sentimentos negativos de insatisfação e desmotivação (gerando menor aproveitamento do curso e aplicação dos conhecimentos de ergonomia aprendidos) 


\section{$\underline{A E T}$}

A AET apresenta uma literatura vasta, completa e consagrada (GUÉRIN et al., 2001; FALZON, 2007; ABRAHÃO et al., 2009) e por isso não foram feitos julgamentos da mesma, nos seus elementos constitutivos. Contudo, foi possível levantar algumas sugestões (abertas a críticas) sobre quais os melhores momentos para um ergonomista aplicar tal metodologia. Os estudos de AET foram aplicados em diferentes fases ao longo do trajeto ergonômico no HU-USP e na análise de atividades locais e na área operativa. Baseado na experiência do pesquisador seja na análise de todo o projeto de ergonomia como no próprio trabalho de graduação (BOLIS, 2007), foi possível afirmar que as análises de AET tiveram sucesso e foram muito úteis em determinadas circunstâncias:

- No começo de um trajeto de melhorias ergonômicas de longo prazo, auxiliando na introdução da temática da ergonomia nas organizações,

- Durante cursos de capacitação técnica, aonde se mostrou uma metodologia de fácil aprendizagem e aplicação, permitindo que pessoas com pouca experiência possam traduzir com facilidade a teoria em prática,

- Em solucionar problemas graves no bem-estar dos trabalhadores,

- No estudo de introdução de melhorias pontuais, seja nos processos, seja nas atividades, seja na estrutura física dos ambientes de trabalho,

- Do lado acadêmico, na fase inicial de aprendizagem na iniciação cientifica de profissionais na área de ergonomia,

- Ao fazer propagandas da temática da ergonomia na organização, depois de conseguir um estudo bem estruturado que possa virar um exemplo, uma referência (best practice).

Porém a experiência do pesquisador mostrou a existência de alguns limites:

- Estudos ergonômicos podem ser compostos exclusivamente de estudos de AET, mas existe o risco em muitas situações de resultados limitados, caso não exista a possibilidade de chamar a atenção para a melhoria de aspectos da organização de trabalho. 
- Análises de AET são demoradas, assim existem limites de tempo para que possam ser aplicadas.

- É necessário que em tais estudos haja um olhar externo, dificilmente uma pessoa é capaz de realizar uma análise completa na própria área.

- Aplicado em nível acadêmico, existe a necessidade de planejar bem as ações. Além de chegar ao diagnóstico, é interessante que o trabalho chegue na fase de implementação prática e na fase de avaliação.

- A conscientização dos trabalhadores e dos gestores das áreas a serem analisadas seria um plus para aumentar a efetividade das soluções. O seu comprometimento com a crença em poder efetivamente melhorar o próprio trabalho é fundamental para envolvê-los e maximizar os benefícios da ação ergonômica.

Resumindo, os estudos AET aplicados em estudos de atividades localizadas em áreas operativas são aconselhados seja na fase de aprendizagem de um novato na ergonomia, seja se aplicadas em grandes problemáticas locais e críticas para a inteira organização. Este último caso é bem raro, assim que o conselho do autor para análises feitas por ergonomistas é que, seja realizada anteriormente uma análise organizacional para introduzir melhorias que impactem na organização como um todo. Apenas num segundo instante, uma vez melhorado o lado organizacional, introduzir estudos de AET para permitir um aperfeiçoamento das soluções em situações locais ainda com margem de melhoria.

\section{O conjunto das ações ergonômicas no HU-USP}

Contextualizando todos os resultados das ações de tipo ergonômico nas oportunidades e limitações presentes no caso do HU-USP, o autor alinha a sua avaliação com aquela da assessor-coordenadora, avaliando positivamente o inteiro processo de aplicação ergonômica. Além dos resultados práticos alcançados, através das entrevistas com os gestores é possível entender como quem teve maior contato com as ações ergonômicas tem uma idéia mais abrangente do que significava ergonomia, recebeu maior sensibilização, e tem em geral um maior cuidado com tais aspectos. Através da mesma entrevista foi reconhecido por 15 
gestores dentre 39 (38,46\%) que existiu forte relação entre a presença de ações de ergonomia e as melhorias alcançadas nas condições de trabalho no HU-USP nos últimos anos. Outro elemento claramente positivo é o numero de gestores com cuidado "presente" ou "proativo" na temática da ergonomia durante um pedido de compra.

Partindo da visão inicial dos pesquisadores, não podemos considerar que o projeto tenha tido completo "sucesso". Aos elementos de sucesso se alternou também outros de insucesso, o que no final foi muito positivo para a finalidade da pesquisa, possibilitando que tais resultados sejam relacionados. A aprendizagem que derivou de tal projeto, sobretudo no CM e no GTC, possibilitou responder a questão de pesquisa inicial. Em particular, os dois elementos a serem analisados de tal questão, o nível aonde se situam a discussão ergonômica na organização e o grau de envolvimento/participação/emancipação dos trabalhadores, além de serem confirmados como importantes para obter resultados ergonômicos mais amplos e duradouros no tempo, puderam ser também relacionados entre si.

\section{2 - Benefícios em elevar a temática da ergonomia no nível estratégico da organização}

As estruturas organizacionais são compostas por vários níveis, sendo que no topo encontra-se os elementos da organização com maior poder de decisão, e normalmente na base a área operacional. Quem trabalha neste último tem um maior conhecimento do trabalho operacional, lugar aonde se encontra os maiores problemas ligados à saúde dos trabalhadores. Em tal contexto, a diretoria tem poder de implementar políticas estruturais para resolver tais problemas, mas que nem sempre são efetivas, não conhecendo detalhadamente os processos e as situações de trabalho. Os operadores, por outro lado, têm alto conhecimento sobre o próprio trabalho, mas não tem poder de decisão abrangente. Isso foi resumido pelo autor através da ilustração 15, alocando no gráfico os atores dos níveis do topo, da linha intermédia, e da base da estrutura organizacional (diretoria, gestores, e área operacional) em relação ao grau de influencia nas decisões da organização e o conhecimento do trabalho operacional. 
A conseqüência é que existem sujeitos da organização com mais poder de decisão e menos conhecimento do trabalho específico (embora tenham conhecimentos gerais que incorporam outros aspectos), e outros em situação oposta.

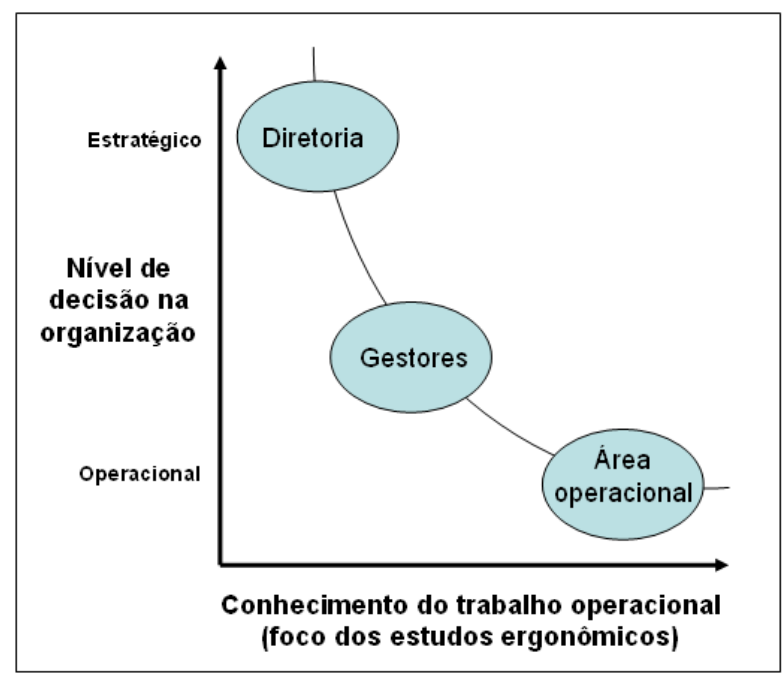

Ilustração 15 - Posicionamento dos sujeitos que atuam na organização entre nível de decisão na organização e conhecimento do trabalho operacional.

Fonte: Elaboração própria a partir dos dados de pesquisa de campo.

Sobre esta base foi concebido todo o processo ergonômico no HU-USP. Como apresentado na ilustração 16, os trabalhos de AET permitiram análises locais na área operacional, e sem necessitar de um suporte particularmente ativo da organização. O potencial de melhoria era localizado exclusivamente naquela situação de trabalho. Sem eliminar estudos de $\mathrm{AET}$, e não esquecendo o trabalho operacional, o GTC nasceu a partir do envolvimento de pessoas com um nível de decisão na organização mais elevado, e os benefícios foram mais amplos. Relembrando os principais resultados, tal proposta permitiu treinar e capacitar 19 pessoas em toda a organização, além de produzir nove trabalhos de AET. Enfim, o $\mathrm{CM}$ envolveu pessoas ainda mais próximas do topo da estrutura organizacional, e as melhorias foram de maior alcance. Entre todos os resultados descritos, a possibilidade de que algum dos trabalhos de AET do GTC fosse implementado na prática já nos dá a idéia do potencial que teve o $\mathrm{CM}$.

A progressão no aumento do potencial de melhorias na evolução das propostas ergonômicas no HU-USP foi totalmente claro, assim podemos afirmar que com um maior engajamento por parte da diretoria (por exemplo, um CM com maior 
comprometimento), as melhorias poderiam ter sido ainda mais estruturais. Este aspecto foi de importância fundamental na experiência desenvolvida pelo autor, o que contrasta com quanto escrito por Ingelgard e Norrgren (2001), que afirmam que o envolvimento da alta diretoria não é um dos fatores mais importantes para obter melhores resultados econômicos e na qualidade de vida no trabalho.

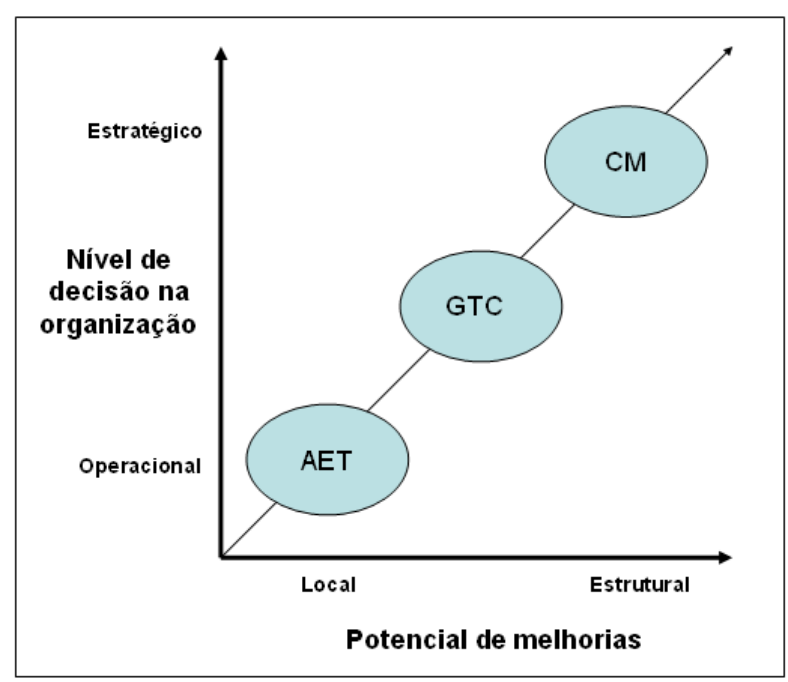

Ilustração 16 - Posicionamento das ações ergonômicas desenvolvidas no HU-USP entre nível de decisão na organização e potencial de melhorias.

Fonte: Elaboração própria a partir dos dados de pesquisa de campo.

O CM assume com este trabalho uma importância fundamental: as outras ações, sobretudo o GTC, não teriam tido tantos benefícios sem a sua constituição. A tarefa do $\mathrm{CM}$ consiste em servir como integrador entre diferentes visões permitindo o alinhamento de dois movimentos, apresentados também como estratégias por Hignett (2001), um descendente (top-down), partindo da diretoria que olha para a organização geral do sistema de trabalho e aos processos relacionados, define as linhas de políticas de melhorias e as faz aplicar, e o outro ascendente (bottom-up), dos trabalhadores das áreas a serem melhoradas que implementam na prática tais políticas e podem apontar os problemas e as oportunidades reais presentes nas situações de trabalho (ilustração 17).

O alinhamento destes dois movimentos, possibilitado através da introdução do $\mathrm{CM}$, tem a potencialidade de trazer à organização amplos benefícios. Um exemplo que esclarece tal afirmação é o caso das compras. Obtivemos evidências do por que a organização ainda não resolveu completamente o problema da presença de compras de equipamentos não ótimos para a saúde dos próprios trabalhadores: 
através da entrevista desenvolvida com o superintendente, para a diretoria comprar através de licitações existem limitações legais, a compra é feita exclusivamente por preço inviabilizando assim alguma melhoria em tal processo. Entrando numa análise do trabalho, porém, quem trabalha nas compras sabe que uma licitação pode ser dirigida ao sucesso inserindo nas licitações especificações com bom nível de detalhe e bem justificadas, deixando claro porque seria melhor comprar, por exemplo, um equipamento mais "confortável".

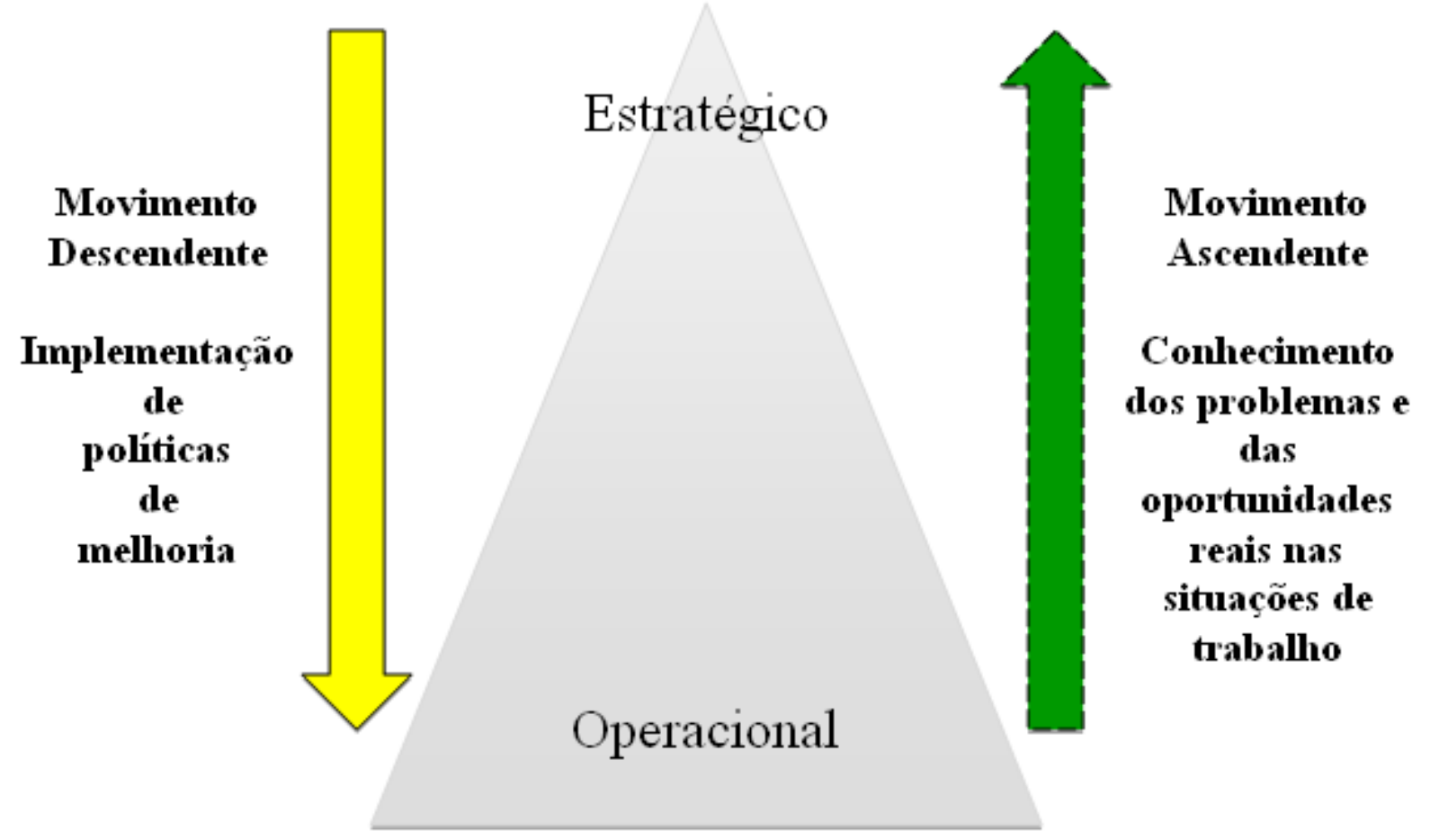

llustração 17 - Movimento descendente e ascendente na organização para a implementação eficaz de políticas de melhoria.

Fonte: Elaboração própria a partir dos dados de pesquisa de campo.

A discussão da ergonomia, que chega da análise da atividade, pode ser assim catalisadora no CM para que o problema das compras seja resolvido, permitindo que o tomador de decisão tenha as informações corretas para suportar ativamente este assunto e implementar as políticas de melhorias mais adequadas. Permitir que pessoas de diferentes lugares da organização entrassem em contato para discutir do assunto de ergonomia, alinhando os próprios conhecimentos, permite que estudos ergonômicos tenham sucesso (TORMA-KRAJEWSKI et al., 2007) . 
Com o CM foi possível sair de uma discussão sobre a temática da ergonomia num nível exclusivamente operacional para envolver também os tomadores de decisão. Dul e Neumann escreveram: "Conectar a ergonomia à estratégia da empresa pode proporcionar aos gerentes uma maior motivação "positiva" para aplicar a ergonomia" (DUL e NEUMANN, 2009, p 746). Ou seja, quanto mais elevamos na estrutura organizacional a introdução do $\mathrm{CM}$, mais forte é o impacto que a ergonomia pode obter na implementação de políticas de melhoria (no movimento descendente). É a diretoria que pode agir sobre os fatores organizacionais, os quais, como estudado por Ku e Smith (2010), têm impacto direto sobre os aspectos sociais e o bem-estar das pessoas na organização. O projeto de ergonomia no HU-USP mostrou claramente que o tipo de visão da diretoria impacta diretamente sobre o grau de sucesso do mesmo. Como conseqüência cresce a importância de obtermos o respaldo ativo da direção, o qual não deve ser feito apenas com palavras (HENDRICK, 2003).

É neste ponto que cabe a ligação com a temática da emancipação dos trabalhadores de todos os níveis da organização. Enquanto subir a discussão da ergonomia na estrutura organizacional quer dizer expandir a amplitude dos benefícios (dando maior força ao movimento descendente), envolver e emancipar os trabalhadores permite aumentar a intensidade dos projetos ergonômicos (dando particular força ao movimento ascendente). Estes dois movimentos se retroalimentam, sendo que o movimento descendente pode criar um ambiente de maior autonomia no qual as pessoas tenham condições para se emancipar, e por outro lado, o movimento ascendente permite resultados de maior sucesso para a empresa, ajudando que os tomadores de decisão tenham maior consciência dos benefícios e apóiem com mais força as melhorias.

\section{3 - Benefícios de um papel proativo dos trabalhadores em vários níveis da organização numa intervenção ergonômica}

Perguntas sobre o grau de envolvimento, o grau de voluntariedade, e tipo de cuidado não faltaram durante as entrevistas, o que permitiu levantar muitos dados sobre a temática da emancipação do trabalhador. Cabe neste ponto fazer uma 
especificação: existe uma impossibilidade de fundo em definir um sujeito emancipado, permanecendo numa estrutura organizacional funcional. Em tal caso o sujeito pode ter um grau maior ou menor de emancipação, mas o seu grau de liberdade e autonomia nunca pode ser total. Partindo desta especificação, em todo o capítulo de resultados nunca foi discutido sobre pessoas emancipadas, mas o tipo de cuidado e o grau de envolvimento proativo caminham na direção da emancipação completa (tabela 22).

O grau de voluntariedade será analisado com grande cuidado por não ser considerado exclusivamente ligado ao grau de emancipação, dependendo também de outros fatores (ex. interesse pessoal).

\begin{tabular}{|c|c|c|c|}
\hline Grau de emancipaçäo & Grau de envolvimento & Tipo de cuidado & Grau de voluntariedade \\
\hline \multicolumn{4}{|l|}{ Nulo } \\
\hline & \multirow{2}{*}{ Suporte } & Ausente & Condicionada sem recusa \\
\hline \multirow{4}{*}{$\underset{\text { Total }}{\downarrow}$} & & Implícito & Condicionada \\
\hline & Ativo - Presente & Presente & Participaçẫo voluntaria \\
\hline & Proativo & Proativo & Totalmente volunt. \\
\hline & & & \\
\hline
\end{tabular}

Tabela 22 - Grau de emancipação.

Fonte: Elaboração própria a partir dos dados de pesquisa de campo.

Unindo todos os resultados obtidos foi possível extrair os seguintes comentários sobre a temática da emancipação em projetos ergonômicos. Em geral, com o aumento do grau de emancipação o sujeito (como descrito graficamente na ilustração 18):

- Chega a resultados ergonômicos mesmo sem a ajuda de um profissional externo na área. Isso foi mostrado por casos encontrados durante a experiência de PA do autor. Na dissertação tal afirmação é confirmada através da postura das pessoas com envolvimento proativo no $\mathrm{CM}$ na instituição. Sem estas pessoas chave poucas das mudanças teriam acontecido, independentemente do que foi introduzido pela equipe da Escola Politécnica.

- Torna-se mais engajado, conhece melhor as ações ergonômicas e os seus objetivos (como no caso dos entrevistados sobre o $\mathrm{CM}$ ), tem um desempenho melhor nas ações ergonômicas (como no caso das entrevistas sobre GTC com pessoas que aprenderam e aplicaram mediamente mais os conceitos de ergonomia) 
e por isso diminui a presença de falsas crenças (como as limitações de mercado e econômicas apresentadas na entrevista com os gestores sobre compras).

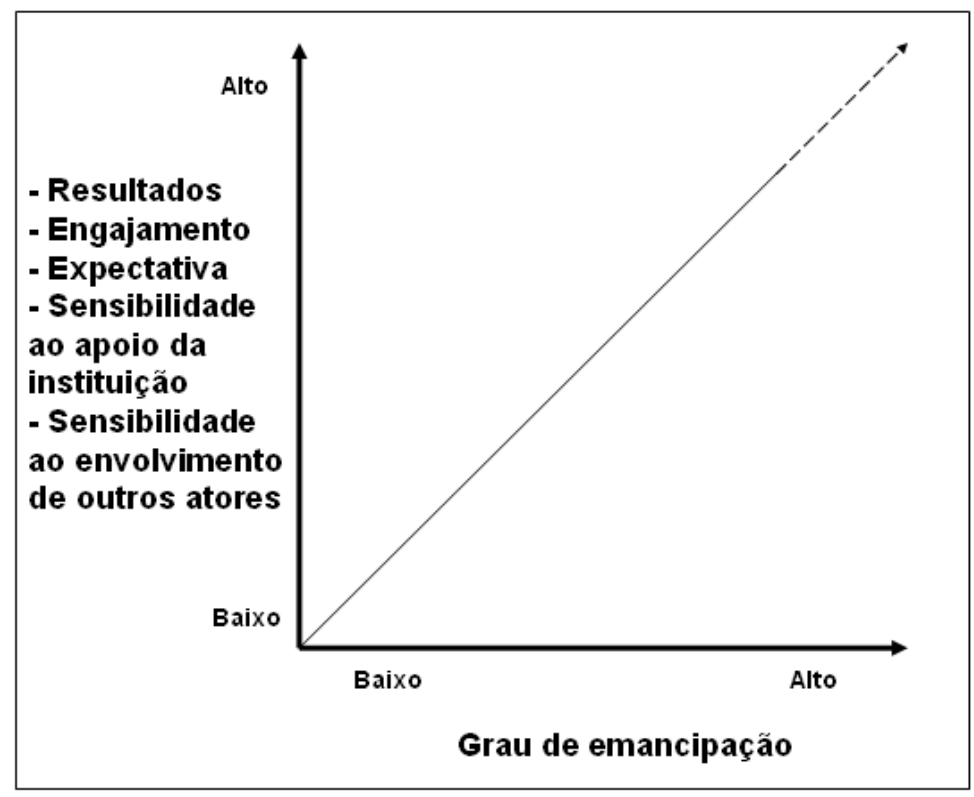

Ilustração 18 - Variáveis com aumento "linear" ao aumento do grau de emancipação.

Fonte: Elaboração própria a partir dos dados de pesquisa de campo.

- Tem geralmente uma expectativa maior sobre os resultados que a ergonomia pode alcançar (como no caso das entrevistas sobre GTC)

- É mais sensível ao grau de apoio da instituição (como na pergunta da visão futura do CM, aonde os mais emancipados - entendendo que a ação ergonômica não tinha importância primaria por parte do tomador de decisão da organização - responderam ter uma visão negativa), sendo assim mais sensível a insucessos e a quando as próprias expectativas não são atendidas (como no caso das entrevistas sobre GTC, com muita desmotivação na avaliação do suporte da organização após o término do curso)

- É mais sensível ao grau de envolvimento de outros atores da organização que tenham influência para o sucesso das ações de ergonomia. (como nas entrevistas sobre CM aonde o grau de envolvimento dos outros participantes e da organização, que foi baixo, provocou altos índices de desmotivação).

O terceiro e quarto ponto permitem a entrega de um resultado muito importante: as organizações precisam atentar para que o grau de emancipação dos próprios 
trabalhadores seja alinhado com as possibilidades reais de influenciar e permitir mudanças e melhorias. Simplificando através da ilustração 19, se a organização permite que os próprios trabalhadores tenham um maior grau de emancipação e, como conseqüência, expectativas maiores, mas tem baixa capacidade de atender tais expectativas, o resultado é o insucesso, fazendo com que tais sujeitos percam o próprio potencial emancipador e a confiança nos benefícios reais de ações ergonômicas. Se este aspecto não é cuidado, pode nascer muita insatisfação nos participantes de tais propostas em relação à gerência, como descrito também no caso apresentado por Pehkonen et al. (2009). Acredita-se que uma postura proativa de uma pessoa isolada tenha efeitos limitados, e há o risco dela se desiludir com o processo. Seria necessário um maior esforço da organização para mostrar as condições adequadas e apoio para ação. Por outro lado, se não existem pessoas "emancipadas", mas existem capacidades da organização em desenvolver ações ergonômicas, o resultado é que ocorra uma real perda de oportunidades.

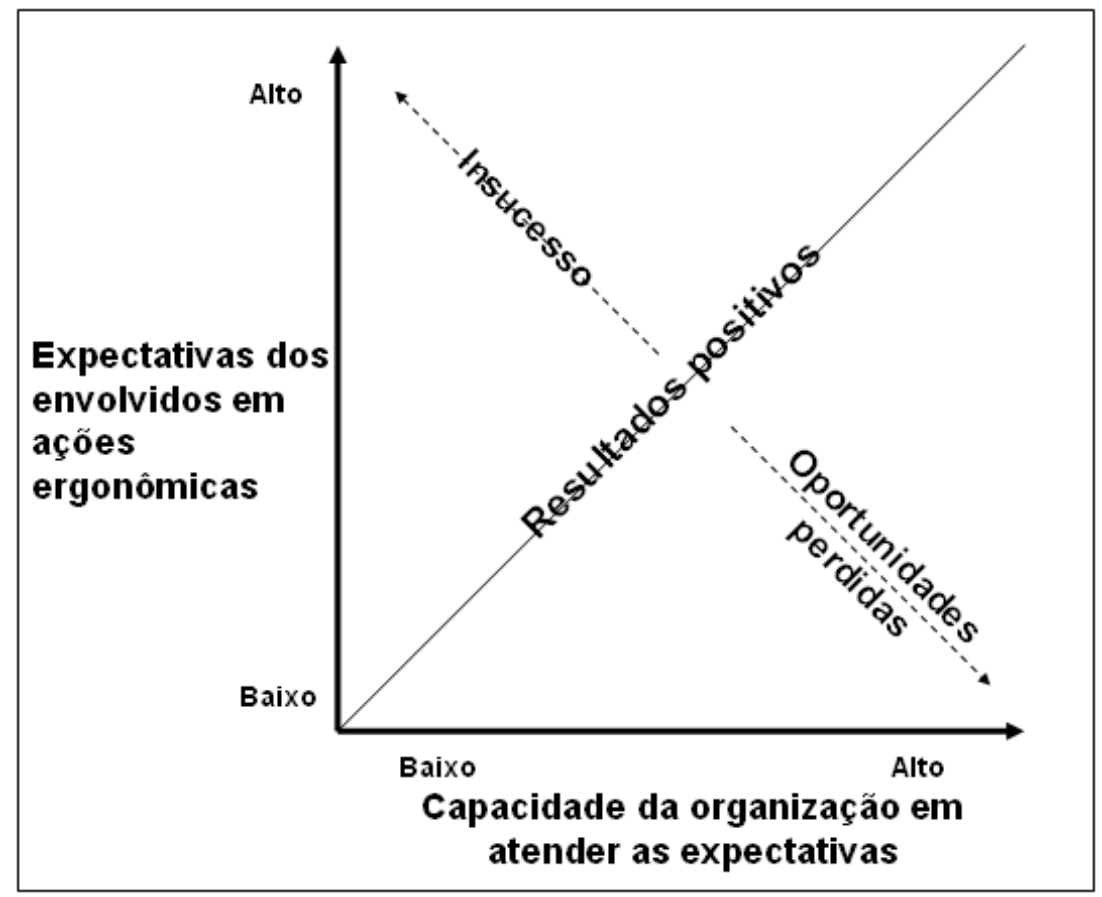

Ilustração 19 - Relação entre expectativas e resultados positivos.

Fonte: Elaboração própria a partir dos dados de pesquisa de campo.

Um resultado intermédio de tais considerações é que pessoas com um maior grau de emancipação permitem a sustentabilidade no tempo de ações ergonômicas: da experiência do $\mathrm{CM}$ podemos extrair que até existam pessoas proativas, as ações 
preventivas e corretivas de tipo ergonômico são desenvolvidas e apoiadas voluntariamente por parte dos trabalhadores, enquanto a desmotivação e a presença de pessoas menos "emancipadas" causam a parada de tais ações.

Embasado nas entrevistas com os gestores sobre compra, existem outros elementos de discussão sobre emancipação, que se apresentam com uma freqüência baixa entre pessoas com grau de emancipação baixo e alto, e com grande freqüência entre os dois extremos de grau de emancipação (como descrito graficamente através da ilustração 20, a qual não tem bases estatísticas), ou seja:

- O conhecimento da presença de problemas sobre a saúde dos trabalhadores. Como explicado nos resultados das entrevistas sobre compras, este indicador é baixo em pessoas pouco emancipadas, porque ou não tem muitos problemas na própria situação do trabalho ou porque não os reconhecem, e nas pessoas muito emancipadas, porque resolvem os problemas logo em seu surgimento. É alto entre as duas situações porque existem os problemas, são visíveis, e precisam ser resolvidos por pessoas que tenham maiores conhecimentos.

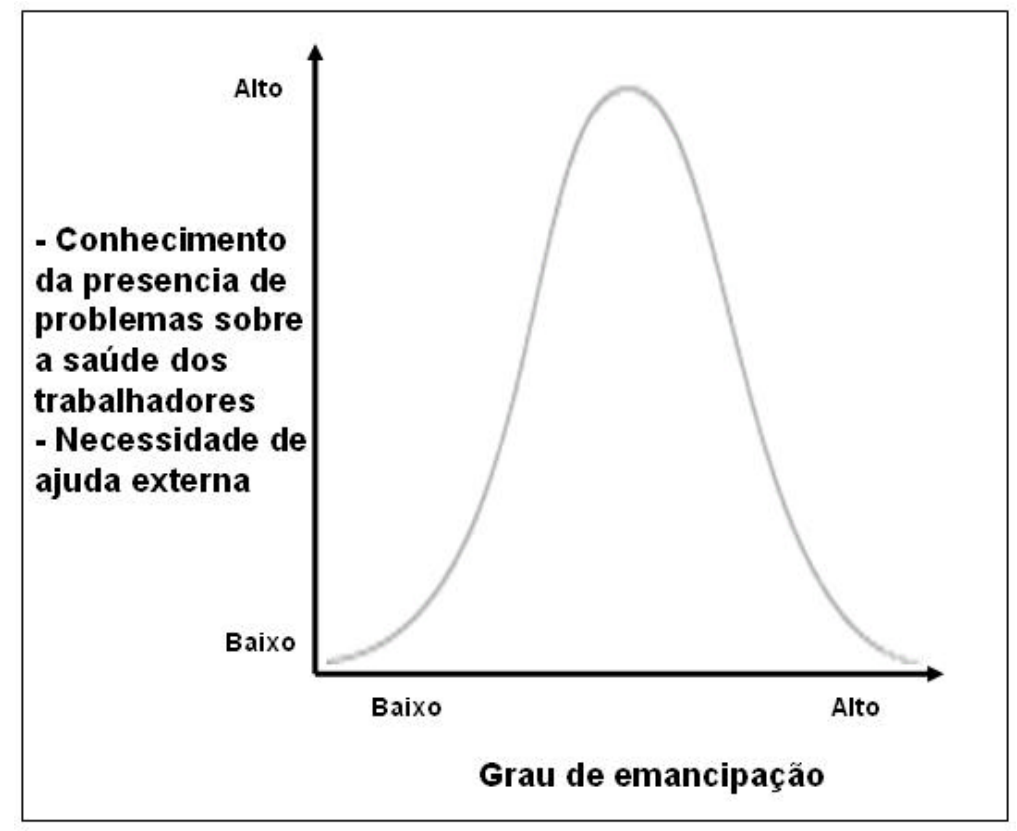

Ilustração 20 - Variáveis com aumento "não linear" ao aumento do grau de emancipação.

Fonte: Elaboração própria a partir dos dados de pesquisa de campo. 
- A necessidade de ajuda de um profissional externo na resolução de problemas. Este indicador é estreitamente ligado ao antecedente; reconhecendo a presença de problemas nas condições de trabalho esta necessidade diminui quanto mais o sujeito é proativo e emancipado, conseguindo resolvê-las até individualmente.

Existem algumas considerações adicionais que foram levantadas:

- As pessoas desejam se envolver quando conseguem ver benefícios diretos ou indiretos para si. Isso quer dizer que precisamos de uma comunicação bem desenvolvida para mostrar os resultados e os possíveis benefícios que podem ser alcançados. Em vários pontos das entrevistas foi levantado como muitas vezes faltaram informações, seja na entrada dos projetos de ergonomia (como no caso do GTC), seja na saída (mesmo caso do GTC) e entre toda a organização.

- A possibilidade de emancipação é independente do nível hierárquico do trabalhador na organização (no GTC, por exemplo, os mais voluntários chegavam da área operacional). Entretanto, quem realmente consegue maior grau de emancipação depende estreitamente do grau de liberdade recebido da organização, o qual no caso do HU-USP aumenta com o crescimento do nível hierárquico na organização (como resultou na entrevista do GTC sobre a aplicação dos conhecimentos adquiridos no GTC, as pessoas da área operacional ficam em situações bem delimitadas e atualmente não se propõem ativamente em sugerir melhorias).

Todas as considerações levantadas até este ponto indicam como um papel proativo dos trabalhadores em vários níveis da organização traz benefícios e resultados reais em intervenções ergonômicas. Os sujeitos proativos se interessam pela saúde dos próprios colegas e de seus subalternos (quando tem cargo de chefia) e tentam melhorar de acordo com nível de autonomia que têm na organização. Estas pessoas não ficam esperando que a organização crie algum meio formal de prevenção ou correção, mas tornam-se eles mesmos uma força ativa que ajuda a organização a se conscientizar e tomar conta o mais rápido possível de tais problemáticas.

Além desta consideração, neste trabalho de dissertação foi claro a estreita ligação do tema de emancipação com o nível da estrutura organizacional no qual a 
discussão da temática da ergonomia se situa. Como mostrado na discussão do primeiro objetivo, com a elevação da temática da ergonomia na estrutura organizacional conseguimos maiores oportunidades de mudança e um maior apoio para eventuais projetos.

A experiência prática no HU-USP mostrou como estes dois aspectos têm que se alinhar e crescer juntos para obter resultados ergonômicos de sucesso global e que sejam sustentáveis ao longo do tempo. Como mostrado no modelo desenvolvido pelo autor (lustração 21), se tais aspectos não são alinhados, os resultados e o sucesso de melhorias podem ser limitados, ou no alcance espacial delimitado apenas nas áreas de trabalho aonde atuam pessoas mais "emancipadas", ou no tempo, aonde melhorias acontecem somente através de políticas descendentes desenvolvidas pela organização.

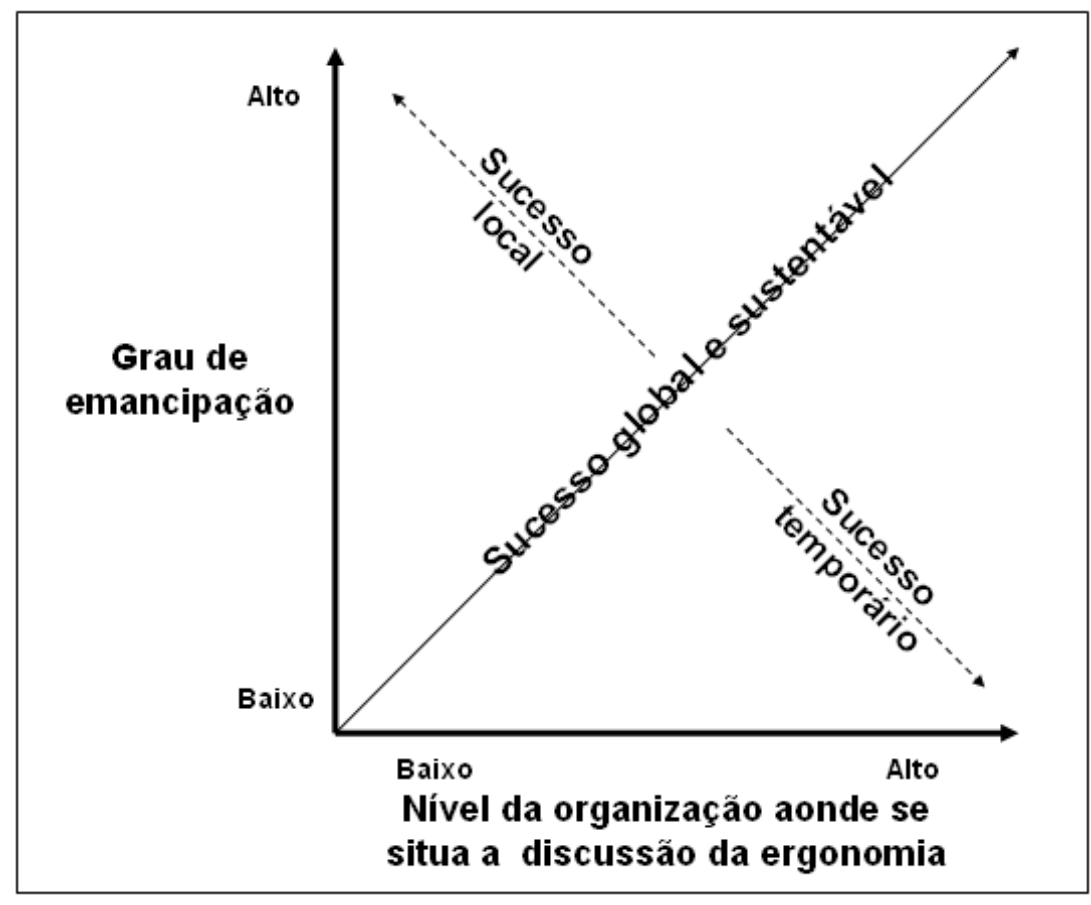

llustração 21 - Tipologia de sucesso com diferentes graus de emancipação dos trabalhadores e diferentes níveis da organização aonde se situa a discussão ergonômica.

Fonte: Elaboração própria a partir dos dados de pesquisa de campo.

Acredita-se que propiciar condições para os sujeitos se engajarem permite levá-los na direção da emancipação. Se tal idéia irá se concretizar não é possível sabermos; permanece no autor da dissertação a idéia que o nível de emancipação pode ser 
fortemente influenciado pela organização que permite espaços de autonomia e condições para a ação, mas depende também das pessoas serem mais ou menos aptas a se emancipar. Ninguém pode obrigar o trabalhador a ter um grau de emancipação maior.

\section{4 - O papel do Comitê de Melhorias}

Segundo Maggi (2006) quanto maior é o envolvimento e a participação do trabalhador, melhor são os resultados conseguidos pelas organizações. Nos textos de ergonomia há várias referências para o fato que nas intervenções ergonômicas os trabalhadores são os melhores conhecedores do próprio trabalho (embora este conhecimento às vezes seja inconsciente e limitado, portanto não explícito) e precisam participar ativamente em tais estudos (FALZON, 2007; ABRAHÃO et al., 2009). Segundo Dejours (2009) existiria uma possibilidade de, através da participação efetiva dos sujeitos em organizações onde a cooperação seja estimulada ao invés de combatida, e onde os sujeitos tenham condições de participar de processos de deliberação internos às empresas, de se trilhar um caminho em direção à emancipação. Embora ainda seja prevalente uma cultura geral de acomodação e de delegar para que outros façam as melhorias, fruto provavelmente de visões pouco democráticas existentes em muitas organizações. As pessoas desejam que melhorias ergonômicas aconteçam em toda a organização e acham as propostas ergonômicas muito interessantes, mas poucos agem efetivamente. Como proposto por Torma-Krajewski et al. (2007), as pessoas deveriam se sentir parte dos processos para garantir 0 sucesso de empreendimentos, como um comitê de ergonomia.

Para maximizar a eficácia da implementação de ações ergonômicas nas organizações o CM deve receber uma importância estratégica, podendo ser o catalisador das ações ergonômicas. Isso é possível através do apoio dos tomadores de decisão da organização que podem permitir que este meio organizacional tome força para que, se bem estruturado, possa ajudar os trabalhadores a senti-lo como um espaço de autonomia para poder agir proativamente na busca de melhorias nas próprias condições de trabalho. Através do $\mathrm{CM}$, diferentes níveis de conhecimento 
poderiam comunicar entre si, havendo assim um aumento da interação entre empregados e diretores (TORMA-KRAJEWSKI et al., 2007). Com tal visão as sugestões de melhoria não precisam chegar ao comitê para serem resolvidas, mas estas questões chegam para voltar aos departamentos de origem com maior força e com um apoio da instituição concedendo autonomia de ação e possibilitando a abertura de espaços para os sujeitos poderem se emancipar. O CM não tem que dar respostas para todos, não sendo constituído por especialistas funcionais, mas deve ser de tipo mais político. Para isso, de modo semelhante ao grupo de "concepção do espaço de trabalho" apresentado por Seim e Broberg (2010), o CM tem que trabalhar com autonomia, ser um meio de disseminação livre de burocracias na estrutura organizacional, lugar de diálogo entre pessoas de diferentes níveis organizacionais e catalisador de todas as ações de ergonomia. Se for possibilitada a presença de um profissional dedicado no interior da organização (coisa considerada positiva), o seu papel precisaria ser parecido com aquele descrito por Dul e Neumann (2009) e Seim e Broberg (2010) de coordenador e de facilitador, e não de especialista em assuntos ergonômicos. Em tal contexto a participação de especialistas externos à instituição pode ser importante para intervenções pontuais e na fase de introdução na organização do CM. 


\section{7 - CONCLUSÃO}

O tema tratado na presente dissertação é muito interessante, mas ao mesmo tempo muito complexo. Durante o desenvolvimento do trabalho foi clara a presença de muitas variáveis que podem influenciar no sucesso (ou insucesso) da implementação de ações ergonômicas que sejam duradouras e de alcance mais extenso. Sem entrar na análise de todas as variáveis, focalizamos exclusivamente em duas variáveis presentes na questão de pesquisa, (ou seja, o grau de envolvimento/participação/emancipação dos trabalhadores, e o nível em que se situa a discussão ergonômica na organização), o que levou a um trabalho de pesquisa bastante amplo. Existem muitos elementos que poderiam ser estudados e analisados para chegarmos às conclusões, assim sendo que o pesquisador precisou fazer um recorte, tentando buscar elementos quantificáveis e com um esforço adicional para não cair em interpretações subjetivas.

Embora tal complexidade, a presente dissertação provou que o trabalhador que tem um maior grau de emancipação consegue agir com mais autonomia e, sem freios por parte da organização, sente-se mais motivado. São estes sujeitos que conseguem introduzir com maior sucesso ações em beneficio da saúde dos trabalhadores não só na própria área de atuação, mas em toda a organização. Paralelamente, este trabalho trouxe evidências sobre aonde melhor situarmos a discussão dentro da organização. No estudo da ergonomia muitas vezes nos detemos na análise de metodologias ou em conceitos mais teóricos, enquanto uma vez aplicada, a prática promove profundas diferenças e melhorias. Esta discussão precisa alcançar esferas mais altas da estrutura organizacional, aproximando-se dos tomadores de decisão da organização, seja para buscar maior engajamento destes como por criar benefícios maiores e mais extensos, que podem ser descritos também em termos econômicos (a fim de incentivar ainda mais o engajamento), que é uma das linguagens mais influentes das organizações voltadas para os negócios.

A pesquisa apresenta algumas limitações, sendo que se encaixa num estudo de pesquisa ação desenvolvido em tempos e espaços bem delimitados. Em relação ao tempo, o pesquisador teve a seu favor o fato de participar na pesquisa no HU-USP já em um estado avançado, tornando possível a análise de outros estudos antecedentes desenvolvidos por outros pesquisadores na mesma instituição. Mesmo 
contando com esta vantagem, a temática da ergonomia ainda não conseguiu se enraizar na organização em análise, sendo que tal projeto provavelmente continuará com novos estudos desenvolvidos por outros pesquisadores. O principal limite temporal consiste no fato que a análise foi desenvolvida partindo de um projeto que não alcançou ainda um sucesso completo, mas sim um sucesso parcial. Do lado espacial, o principal limite consiste no desenvolvimento da pesquisa numa empresa pública e ligada a outra instituição maior (a universidade). As características principais que delimitam este trabalho é o fato do HU-USP ser uma instituição de pesquisa e ter uma estrutura organizacional particular. Ser dedicada à pesquisa provoca a vantagem de as pesquisas serem bem aceitas e, relativamente, facilmente desenvolvidas. Por outro lado, também pela quantidade de pesquisas em constante andamento, estas dificilmente são introduzidas num nível superior ao operacional, sobretudo se a demanda da pesquisa é mais externa que interna na instituição (como no caso da Ergonomia). Sucessivamente, a estrutura organizacional encontrada no HU-USP pode ser considerada outro grande elemento que limita os resultados da atual pesquisa. Estruturas onde há concentração de poder dificultam este tipo de processo.

Para superar esses limites, é fundamental que se consiga um alinhamento organizacional que tenha como ponto de apoio, os níveis mais elevados de decisão para que este tipo de política seja efetiva e possa ser ampliada e durar. Além disso, seria importante que se desenvolvessem outras pesquisas no HU-USP, e também em empresas não públicas e orientadas a um mercado competitivo. Enfim, os novos projetos desse estilo poderiam ter mais sucesso se desenvolvidos em empresas com um engajamento direto e ativo da diretoria, além de serem bem planejados e integrados nos processos de produção e de trabalho da instituição / empresa. Isso poderia permitir confirmar ou não o quanto foi discutido neste trabalho, possibilitando resultados mais universais. 


\section{8 - REFERÊNCIAS BIBLIOGRÁFICAS}

ABRAHÃO, J.; SZNELWAR, L.I.; SILVINO, A.; SARMET, M. PINHO, D. Introdução à ergonomia da prática à teoria. São Paulo: Blucher, 2009.

ACOSTA, G.; MORALES, L. Macroergonomic study of food sector company distribution centres. In: Applied Ergonomics, vol. 39(4), 2008.

ALBUQUERQUE, L. G. A Gestão Estratégica de Pessoas. In: FLEURY, M. T. L. (Org) As Pessoas na organização, São Paulo: Gente, 2002.

ALTRICHTER, H.; POSCH, P.; SOMEKH, B. Teachers investigate their work: An introduction to the methods of action research. London, UK: Routledge, 1993.

ALVARINHO, E.; WU, M. J. Olhar, Refletir e Transformar: um aprendizado construído no Hospital universitário /USP. São Paulo: Hospital Universitário da USP (Relatório final de estágio), 2002.

ANFOSSI, A. Prospettive sociologiche sull'organizzazione aziendale. Gli esperimenti di Hawthorne, Franco Angeli, p. 108-122, 1971.

ANTUNES, R. Os sentidos do trabalho: Ensaio sobre a afirmação e a negação do trabalho. 6ª ed. São Paulo: Boitempo, 2003.

AVOLIO, B. J. e WALDMAN D. A. Variations in Cognitive, Perceptual, and Psychomotor Abilities Across the Working Life Span: Examining the Effects of Race, Sex, Experience, Education, and Occupational Type. In: Psychology and Aging, vol. 9, n. 3, p. 430-442, 1994.

BALSAMO, A. C. Estudo sobre os acidentes de trabalho com exposição aos líquidos corporais humanos em trabalhadores da saúde. Escola de Enfermagem da Universidade de São Paulo, dissertação (Mestrado em enfermagem), São Paulo, 2002.

BALSAMO, A. C., BARRIENTOS, D. S. \& ROSSI, J. C. B. Acidentes de trabalho com exposição à líquidos corporais humanos ocorridos nos funcionários do Hospital Universitário da Universidade de São Paulo (HU-USP). In: Revista Médica HU-USP, vol. 10(1) p. 39-45, 2000. 
BARNARD, C. I. Functions of the executive. Cambridge Harvard University, p.334, 1947.

BARTEZZAGHI, E. L'organizzazione dell'impresa. Processi, progetti, conoscenza, persone, Editore Etas, 2010.

BECKER, G. S. El capital humano. Madrid: Alianza Universidad Textos, 1983.

BICKMAN, L.; ROG, D. (Eds). The handbook of applied social research methods. Los Angeles, CA: Sage Publications Inc., 2009.

BOLIS, I. Analisi ergonmica in ambiente ospedaliero. Studio del caso HUUSP. Trabalho de formatura, Politecnico di Milano, Milano, 2007.

BONAZZI, G. I quattro principi alla base dell'Organizzazione Scientifica del Lavoro. In: Storia del pensiero organizzativo, Franco Angeli, p. 40-49, 2002.

BORDUM, A. From Tacit Knowing to Tacit Knowledge-Emancipation or Ideology? In: Critical Quarterly, vol. 44, n. 3, p.50-54, 2002.

BRADBURY, D. Ergonomics: Hidden costs of the uncomfortable workplace,. Disponível em http://www.ft.com/cms/5b39b180-c6d1-11db-8f4f000b5df10621.html, Acesso em: 03 de maio de 2009.

BROWN Jr. O. The development and Domain of Participatory Ergonomics. In: Proceedings of the IEA world Conference 1995, Rio de Janeiro, 1995.

BUGAJSKA J., MAKOWIEC-DABROWSKA T., JEGIER A., MARSKALEK A. Physical work capacity (VO2 max) and work ability (WAI) of active employees (men and women) in Poland. In: Elsevier International Congress Series, vol. 1280, p. 156-160, 2005.

BUREAU OF LABOR STATISTICS Injuries, Illnesses, and Fatalities.

Disponível em: http://www.bls.gov/iif/. Acesso em: 18 de novembro de 2010.

CASADO, T. A motivação e o trabalho. In: FLEURY, M. T. L. (Org) As pessoas na organização. São Paulo: Gente, 2002.

CASSANO, G. R. Proposta de reestruturação do processo e do setor de montagem das refeições do SND do HU-USP. 133 p. Trabalho de Formatura - Escola Politécnica, Universidade de São Paulo, São Paulo, 2010. 
CATALDI, P.; ABATE, E.; LUPERINI, S.; MARCHIANI, L.; SPINGOLA, C.; Di fronte alla storia - Volume 2. Dalla guerra dei Trent'anni all'imperialismo (1648-1914). Scuola secondaria di $2^{\circ}$ grado - Storia, 2009.

CHAPANIS, A. Engenharia e o relacionamento homem-máquina. São Paulo, Atlas, 1997.

CHECKLAND, P.; HOLWELL, S. Action Research: Its Nature and Validity. In: Systemic Practice and Action Research, vol. 11(1), p. 9-21, 1998.

COCKELL, F. F.; VASCONCELOS, R. Importância da continuidade do processo de intervenção ergonômica através do comitê de ergonomia: um estudo de caso. Anais do VII Congresso Latino-Americano de Ergonomia XII Congresso Brasileiro de Ergonomia I Seminário Brasileiro de Acessibilidade Integral, 2002.

CORBETTA, P. Metodologia e tecnica della ricerca sociale. II Mulino, Bologna, 1999.

CORIAT, B. Pensar pelo avesso. 0 modelo japonês de trabalho e organização. Rio de Janeiro: UFRJ/Revan, 1994.

COSTA, T. F.; FELLI, V. E. A. Exposição dos trabalhadores de enfermagem às cargas químicas em um hospital público universitário da cidade de São Paulo. In: Revista Latino-Americana de Enfermagem, vol.13, n.4, 2005.

CRESWELL, J. W. Projeto de Pesquisa: métodos qualitativo, quantitativo e misto. Trad. Luciana de Oliveira da Rocha. $2^{a}$ ed. Porto Alegre: Artmed, 2007.

DANIELLOU, F. A ergonomia em busca de seus princípios: debates epistemológicos. São Paulo, Edgar Blucher, 2004.

DANIELLOU, F. The French ergonomists' approach to work activity: Crossinfluences of field intervention and conceptual models. In: Theoretical Issues in Ergonomics Science, vol. 6(5), p. 409-27, 2005.

DAS, B.; SHIKDAR, A. Participative versus assigned production standard setting in a repetitive industrial task: A strategy for improving worker productivity. In: International Journal of Occupational Safety and Ergonomics, vol. 5(3), p. 417-430, 1999. 
DERANGO, K; AMICK, B .C; ROBERTSON M .M.; ROONEY, T.;BAZANNI, L. The Productivity Consequences of Two Ergonomic Interventions, Institute for Work and Health Working Paper 286, Toronto, Canada, 2003.

DEJOURS, C. A banalização da injustiça social. Trad. Luiz Alberto Monjardim. Rio de Janeiro: Fundação Getúlio Vargas, 3 ed., 2000.

DEJOURS, C. Nouvelles formes de servitude et suicide. Travailler, 13, 53-73, 2005.

DEJOURS, C. Entre o desespero e a esperança: como reencantar o trabalho? Cult [S.I.], vol. 139, p. 49-53, 2009.

DIESAT Anuário Estatístico de Acidentes de Trabalho de 2007. Disponível em: http://www.diesat.org.br/arquivos/aeat2007.pdf. Acesso em: 18 de novembro de 2010.

DRUCKER, P. Sociedade pós-capitalista. 6.ed., Pioneira, São Paulo, 1993.

DUARTE, F. Complementaridade entre ergonomia e engenharia em projetos industriais. In: Ergonomia \& projeto na indústria de processo contínuo. Rio de Janeiro: Editora Y. H. Lucerna LTDA, 2001.

DUL, J.; NEUMANN, W. P. Ergonomics Contributions to Company Strategies. In: Applied Ergonomics, vol. 40(4), p. 745-752, 2009.

DURANT, R.A.; CASHMAN, J.F. Theorizing limits: an exploration of boundaries, learning, and emancipation. In: Journal of Organizational Change Management, vol. 16. n. 6, p. 650-665, 2003.

DUTRA, A. R. A. Introdução à Ergonomia. PR. Unioeste, 2003.

EMERY, F. E.; TRIST, E. L. Sistemi socio-tecnici, tr. it.. In: FABRIS A.; MARTINO F. "Progettazione sviluppo delle organizzazioni", Etas Libri, p. 28-33, 1974.

EUROPEAN AGENCY FOR SAFETY AND HEALTH AT WORK. Quality of the working environment and productivity - Research findings and case Studies. http://www.osl.upf.edu/pdfs/quality_productivity_en.pdf, Luxembourg, 2004.

FACCHINI, A. R.; BIGNETTI, L. P. O papel do executivo e o alcance das práticas de RH: o desafio da eficácia. In: XXVIII Encontro Nacional da 
associação macional de pós-graduação e pesquisa em administração ANPAD, Curitiba, 2004.

FALZON, P. Ergonomia. São Paulo, Edgard Blucher, 2007.

FALZON, P.; SAUVAGNAC, C. Carga de trabalho e estresse. In: FALZON, P. Ergonomia. São Paulo: Ed. Edgar Blucher, p. 141-154, 2007.

FISCHER. A. L., Um resgate conceitual e histórico dos modelos de gestão de pessoas. In: FLEURY, M. T. L. (Org) As Pessoas na organização, São Paulo: Gente, 2002.

FLEURY, M. T. L. A Gestão de Competência e Estratégia Organizacional. In: FLEURY, M. T. L. (Org) As Pessoas na Organização. São Paulo: Gente, 2002.

FLEURY, M. T. L.; OLIVEIRA JR. Aprendizagem e Gestão do Conhecimento. In: FLEURY, M. T. L. (Org) As Pessoas na organização, São Paulo: Gente, 2002.

FOCCILLO A. Quali partiti e quale sindacato?. Disponível em: http://www.uil.it/li-notizie/li-lug-ago2010.htm. Acesso em: 18 de novembro de 2010.

FREITAS, L. G. O processo de saúde e adoecimento dos professores que atuam em ambiente virtual. Em Mendes, A. M. (org) A psicodinâmica do Trabalho: teoria, método e pesquisas. São Paulo: Casa do Psicólogo, 2007.

FUGULIN F. M. T.; GAIDZINSKI R. R.; KURCGANT P. Ausências previstas e não previstas da equipe de enfermagem das unidades de internação do $\mathrm{HU}$ USP. In Revista da Escola de Enfermagem USP; vol. 37(4), p. 109-17, 2003.

FUNDCÃO NACIONAL DA QUALIDADE (FNQ). Cadernos de Excelência: Pessoas. Série Cadernos de Excelência, n. 6, São Paulo, 2008.

GEIGER, A.; SZNELWAR, L. I. Criação e institucionalização do comitê de melhorias no Hospital Universitário. Relatório final de Ergonomia e Psicodinâmica do trabalho, São Paulo: EPUSP. Departamento de Engenharia de Produção / FCAV (relatório técnico), 2008. 
GENERALIS, G.; MYLONAKIS, J. Productivity and Ergonomics: A Strong Relationship Leading to Best Working Results. In: European Journal of Social Sciences, vol 5, n.1, 2007.

GIANOLA, R. Lo strappo di Pomigliano. Disponível em: http://www.sinistraeliberta.eu/vetrina/lo-strappo-di-pomigliano -inaugurafabbrica-italia-ma-per-fiat-e\%CC\%80-solo-l\%E2\%80\%99inizio. Acesso em: 18 de novembro de 2010.

GUIMARÃES, L. B. M. Análise Macroergonômica do Trabalho (AMT): modelo de implementação e avaliação de um programa de ergonomia na empresa. In: Produto e Produção, Porto Alegre, 1999.

GUIMARÃES, L. B. M. Análise Macroergonômica do Trabalho (AMT): modelo de implementação e avaliação de um programa de ergonomia da empresa. In: Produto e Produção. Porto Alegre, 2002.

GUMMESSON, E. Qualitative Methods in Management Research. Thousand Oaks, CA: Sage, (revised 2nd edition), 2000.

HAAK, M. K. Programas de qualidade e a motivação para o trabalho: um estudo exploratório no setor de serviços. In: Revista de Administração, vol. 35(30), p. 60-70, 2000.

HAGG, G. M. Corporate initiatives in ergonomics - an introduction. In: Applied Ergonomics, vol. 34, p.3-15, 2003.

HAINES, H; WILSON JR; VINK, P, KONINGSVELD, E. Validating a framework for participatory ergonomics (the PEF). In: Ergonomics, vol. 45, p. 309-327, 2002.

HARO, E., KLEINER, B. M. Macroergonomics as an organizing process for system safety. In: Applied Ergonomics, vol. 39, n. 4, p. 450-458, 2008.

HARRISON, M. I. Diagnosing Organizations: Methods, Models, and Processes. Thousand Oaks, CA: Sage Publications, 2004.

HENDRICK, H. W. Human factors in organizational design and management. In: Ergonomics, vol. 34, p. 743-756, 1991.

HENDRICK, H. W. Determining the cost-benefits of ergonomics projects and factors that lead to their success. In: Applied Ergonomics , vol. 34, p. 419-427, 2003. 
HENDRICK, H. W. ODAM and macroergonomics 20 years later: You've come a long way baby! In: Human Factors in Organizational Design and Management - VIII (P. Carayon, M. Robertson, B. Kleiner, P.L.T. Hoonakker, eds) Santa Monica: IEA Press, p. 25-34, 2005.

HENDRICK, H. W. Applying ergonomics to systems: Some documented "lessons learned". In. Applied Ergonomics, vol. 39, p. 418-426, 2008.

HENDRICK, H. W.; KLEINER, B. M. Macroergonomics: an introduction to work system design. Santa Monica, CA: Human Factors and Ergonomics Society, 2001.

HERTZBERG, F.; MAUSNER, B.; SNYDERMAN, B. B. The Motivation to Work (2nd ed.). New York: John Wiley \& Sons, 1959.

HIGNETT, S. Embedding ergonomics in hospital culture: top-down and bottomup strategies. In. Applied Ergonomics; vol. 32, p. 61-69, 2001.

IIDA, I. Ergonomia: Projeto e Produção. São Paulo: Edgard Blücher, 1990.

IMADA, A. The rationale and Tools of Participatory Ergonomics. In: NORO K.; IMADA A. S. (eds.) Participatory Ergonomics, Taylor and Francis, Londres, p. 30-50, 1991.

IMADA, A.; CARAYON, P. Editors' comments on this special issue devoted to macroergonomics. In: Applied Ergonomics, vol. 39(4), p. 415-417, 2008.

IMBIMBO, M.; PARASPORO, L.; SALUCCI, M. Viaggio nella filosofia, vol. 3, Palumbo Editore, Palermo 2004.

INGELGARD, A.; NORRGREN, F. Effects of change strategy and topmanagement involvement on quality of working life and economic results. In: International Journal of Industrial Ergonomics, vol. 27, p. 93-105, 2001.

JENKINS, S., RICKARDS, J. The economics of ergonomics: three workplace design case studies. In: ALEXANDER, D.C.; RABOURN, R. (Eds.), Applied Ergonomics. Taylor \& Francis, London, p. 336, 2001.

KLEIN, H. K.; MYERS, M. D. A set of principles for conducting and evaluating interpretive field studies in information systems. In: Management Information Systems Quarterly, vol. 23(1), p. 67-88, 1999. 
KUORINKA, I. Participatory ergonomics at the shop floor level. In:

KARWOWSKI, W.(Ed. ), International Encyclopedia of Ergonomics and Human Factors. Taylor \& Francis, London, p. 1290-1292, 2001

KRAFCIK, J. F. Triumph of the Lean Production System. In: Sloan Management Review, vol 30, n 1, p 41-52, 1988.

KUHNE, G. W.; QUIGLEY, B. A. Understanding and Using Action Research in practice Settings. In QUIGLEY, B. A.; KUHNE, G. W. Creating Practical Knowledge Trough Action Research: Posing Problems, Solving Problems, and Improving Daily Practice, San Francisco: Jossey-Bass Publishers, p. 2340, 1997.

KVALE, S. Doing Interviews: the Sage Quality Research Kit, The Cromwell Press Ltd., Trowbridge, 2007.

LAMBERT, R.; WEBSTER, E. Social emancipation and the new labour internationalism: a southern perspective. In: SOUSA SANTOS, B. (ed) Another Production is Possible: beyond the capitalist canon. London and New York: Verso, 2006.

LANCMAN, S.; ROMERO, M. M. L.; SANTOS, M. C. dos; BONEQUINI, Renata Letícia. Informar e Refletir: uma experiência de Terapia Ocupacional. Revista de Terapia Ocupacional da Universidade de São Paulo. São Paulo, 2004

LANCMAN S.; UCHIDA S. Trabalho e subjetividade: o olhar da Psicodinâmica do Trabalho. In: Cadernos de Psicologia Social do Trabalho, vol. 6, p. 79-90, 2003. http://www.revistasusp.sibi.usp.br/pdf/cpst/v6/v6a06.pdf

LEPLAT, J.; MONTMOLLIN, M. As relações de vizinhança da ergonomia com outras disciplinas. In FALZON, P. Ergonomia. Editora Blucher, 2007.

LIMONGI-FRANÇA, A. C.; ARELLANO, E. B. Os processos de recrutamento e seleção. In: FLEURY, M. T. L. (Org) As pessoas na organização, São Paulo: Gente, 2002.

LOPES, D. R.; GUIMARÃES, L. B. Apreciação ergonômica no trabalho de auxiliares de enfermagem do bloco cirúrgico do hospital de clinicas de Porto Alegre. In: Ação Ergonômica, vol.1, n. 2, p. 92, 2001.

MAGGI, B. Lavoro organizzato e salute, Tirrenia Stampatori, Torino, 1991. 
MAGGI, B. L'Ergonomia e le scienze umane. In: Ergonomia, n.1, p.58-60, Moretti e Vitali Ed., Bergamo, 1993.

MAGGI, B. Do agir organizacional: um ponto de vista sobre o trabalho, o bem-estar, a aprendizagem. São Paulo: Edgard Blucher, 2006.

MARRAS, W. S.; ALLREAD, W. G. How to develop and manage an ergonomics process. Colombus: Institute for Ergonomics, The Ohio State University, 2005.

MARX, Karl. Manuscritos econômico-filosóficos. São Paulo, Martin Claret, 2002.

MASLOW, A. H. Motivation and Personality. New York: Harper \& Row, 1954.

MASLOW, A. Diário de negócios de Maslow. São Paulo, Qualitymark, 2003.

McDONAGH, J.; COGHLAN, D. The art of clinical inquiry in information technology-related change. In: Reason, P. and Bradbury, H. (eds.), Handbook of Action Research, London: Sage, p.372-378, 2001.

McGREGOR, D. The Human Side of Enterprise. New York: McGraw-Hill, 1960.

McNAMARA, C. General guidelines for conducting interviews. Disponível em: http://managementhelp.org/evaluatn/intrview.htm. Acesso em: 27 outubro 2010.

MINISTERIO DA PREVIDENCIA SOCIAL. Saúde e Segurança Ocupacional. Disponível em: http://www.previdenciasocial.gov.br/conteudoDinamico.php?id=39. Acesso em: 05 de outubro de 2010 (a).

MINISTERIO DA PREVIDENCIA SOCIAL. Anuário Estatístico de Acidentes do Trabalho 2008. Disponível em: http://www.previdenciasocial.gov.br/ conteudoDinamico.php?id=904. Acesso em: 05 de outubro de 2010 (b).

MINISTÉRIO DO PLANEJAMENTO: Avaliação da Gestão de Recursos Humanos no Governo - Relatório da OCDE. Brasil 2010. Disponível em: http://www.planejamento.gov.br/secretarias/upload/Arquivos/noticias/srh/10052 0_estudo_OCDE.pdf. Acesso em: 03 de dezembro de 2010. 
MINTZBERG, H. Criando organizações eficazes. São Paulo: Atlas, 2003.

MONTGOMERY, D. Citizen Worker: The Experience of Workers in the United States with Democracy and the Free Market during the Nineteenth Century. New York: Cambridge UP, 1993.

MOORE, J. S.; GARG, A. The Effectiveness of Participatory Ergonomics in the Red Meat Packing Industry: Evaluation of a Corporation. In: International Journal of Industrial Ergonomics, vol. 21, p. 47-58, 1998.

MOTTA, F. P.; VASCONSELOS, I. Teoria Geral da Administração. São Paulo: Thomson Pioneira, 2002.

NAGAMACHI, M. Requisites and practices of participatory ergonomics. In: International Journal of Industrial Ergonomics, vol. 15, p. 371-377, 1995.

NAGAMACHI, M. Relationship beetween Job Design, Macroergonomics and Productivity, In: Human Factors and Ergonomics in Manufacturing. New York: John Willey. vol. 6, n. 4, p. 309-322, 1996.

NAKAHARA, D. Análise ergonômica do trabalho de distribuição de refeições no HU-USP. 132 p. Trabalho de Formatura - Escola Politécnica, Universidade de São Paulo, São Paulo, 2008.

NATIONAL INSTITUTE FOR OCCUPATIONAL SAFETY AND HEALTH. A critical review of epidemiologic evidence for work-related musculoskeletal disorders of the neck, upper extremity, and low back. Disponível em: http://www.cdc.gov/niosh/docs/97-141/. Acesso em: 03 de maio de 2009.

NEUMANN, W. P.; EKMAN, M.; WINKEL, J. Integrating ergonomics into production system development - The Volvo Powertrain Case. In: Applied Ergonomics. 40 (3) s. 527-537, 2009.

NEUMANN, P.; WINKEL, J. Ergonomics and effective production systems moving from reactive to proactive development. Swedish National Institute for Working Life and Volvo Powertrain in Skövde, Sweden, 2005.

NONAKA, I.; TAKEUCHI, H. The Knowledge Creating Company. University Press, Oxford, 1995.

NORMANN, R. Administração de Serviços. Atlas, São Paulo, 1993. 
NUNES C. M.; TRONCHIN D. M. R., MELLEIRO M. M.; KURCGANT P. Satisfação e insatisfação no trabalho na percepção de enfermeiros de um hospital universitário. Revista da Escola da Enfermagem da USP. Disponível em: http://www.fen.ufg.br/revista/v12/n2/v12n2a04.htm,12(2):252-7, 2010

OCCUPATIONAL HEALTH CLINICS FOR ONTARIO WORKERS (OHCOW). Resource Guide Ergonomics Committee Workbook. OHCOW Canadá. Disponível em: http://www.ohcow.on.ca, Ontário. 2001.

OECD. Country statistical profiles 2010: Brazil. Disponível em: http://stats.oecd.org/index.aspx?queryid=23113. Acesso em: 03 de dezembro de 2010.

OLIVEIRA, M. M. Como fazer pesquisa qualitativa. Recife: Bagaço, 2005.

PEHKONEN, I.; TAKALA, E. P.; KETOLA, R.; VIIKARI-JUNTURA, E.; LEINOARJAS, P.; HOPSU, L.; VIRTANEN, T.; HAUKKA, E.; HOLTARI-LEINO, M.; NYKYRI, E.; RIIHIMAKI, H. Evaluation of a participatory ergonomic intervention process in kitchen work. In: Applied Ergonomics, vol. 40, p. 115-123, 2009.

PÉRILLEUX T. L'autonomie est-elle encore un idéal d'émancipation dans le travail?, in Travailler. Revue Internationale de Psychopathologie et de Psychodynamique du Travail, $n^{\circ} 1$, p. 17-39, 1998.

PIRES, M. R. G. M. Politicidade do cuidado e processo de trabalho em saúde : conhecer para cuidar melhor, cuidar para confrontar, cuidar para emancipar. In Ciência e saúde coletiva, vol. 10, n. 4, p. 1025-1035, 2005.

RESNICK, M. L.; ZANOTTI, A. Using ergonomics to target productivity improvements. In: Computers and hdustrial Engineering, vol. 33(1-2), p. 185-188, 1997.

ROBERTSON, M. M., AMICK, B., DERANGO, K., PALACIOS, N., ROONEY, T., ALLIE, P.; BAZZANI, L. The Impact of an Office Ergonomics Training on Worker Knowledge, Behavior and Musculoskeletal Risk. In: Proceedings of the Conference on Work With Display Units, Berchtesgaden, Germany, p. 1112-1115, 2002. 
RULLI, G; CRISTOFOLINI, A.; TOMMASINI, M.; VELASCO, R.; GRANDO, M.S.; GIRARDI, G.; ASTE, F. Le attività di laboratorio con uso di sostanze cancerogene-mutagene. Un'esperienza di valutazione e gestione del rischio tramite l'applicazione del Metodo delle Congruenze Organizzative, Edizioni Provincia Autonoma di Trento, Assessorato alle Politiche per la Salute, Trento, 2004.

SABATINI COLETTI, Dizionario della lingua Italiana, Rizzoli Larousse, 2007.

SANDERS, M. S.; McCORMICK, E. J. Human factors in Engineering and Design. McGraw-Hill, Inc, 1993.

SCHEIN, E.H. Process consultation revisited: Building the helping relationship. Reading, MA: Addison-Wesley, 1999.

SCHMITTER, D. Ergonomia. Un fattore di successo per ogni impresa, SUVA, Istituto nazionale svizzero di assicurazione contro gli infortuni, Cartoon, 2003.

SEIM, R.; BROBERG, O. (2010). Participatory workspace design: A new approach for ergonomists? In: International Journal of Industrial Ergonomics, vol. 40, p. 25-33, 2010.

SILVA-BAU', L.M. Fisioterapia do trabalho: ergonomia, legislação, reabilitação. Curitiba: Cladosilva, 2002.

SILVERSTEIN, B. A.; RICHARDS, S. E.; ALCSER, K.; SCHURMAN, S. Evaluation of in-plant ergonomics training. In: International Journal of Industrial Ergonomics, vol. 8, p. 179-193, 1991.

SIMON, H. (1947) Administrative behavior; a study of decision-making processes in administrative organization. New York, Macmillan, 1947.

SMITH, V. Worker participation: current research and future trends. Amsterdam: Elsevier, 2006.

SOARES, M. M.; SILVA, G. G. A. S.; RAMOS, D. T. F.; CABRAL, G. G.; CRUZ, J. L. D. Os primeiros passos de um programa de ergonomia na empresa: duas experiências distintas. In: Revista Gestão Industrial, vol. 03, n. 03: p.160-171, Paraná, Brasil, 2007. 
ST-VINCENT, M.; CHICOINE, D.; BEAUGRAND, S. Validation of a participatory ergonomic process in two plants in the electrical sector. In: International Journal of Industrial Ergonomics, vol. 21, p. 11-21, 1998.

SZNELWAR, L. I.; LANCMAN, S.; WU, M. J.; ALVARINHO, E.; SANTOS, M.d. Análise do Trabalho e serviço de limpeza hospitalar: contribuições da ergonomia e da psicodinâmica do Trabalho. Revista Produção, São Paulo, vol. 14, p. 45-57, 2004.

SZNELWAR, L. I.; MASCIA, F. L., ZILBOVICIUS, M.; MONTEDO, U.;UCHIDA, S.; LANCMAN,S.; VEZZÁ, F.G. Programa de cooperação técnica HU / FCAV. São Paulo: EPUSP. Departamento de Engenharia de Produção / FCAV (relatório técnico), 2006.

SZNELWAR, L. I.; NEIVA, A. G. Relatório Final: Criação e Institucionalização do Comitê de Melhorias no Hospital Universitário. São Paulo: EPUSP. Departamento de Engenharia de Produção / FCAV. (relatório técnico), 2008.

THIOLLENT, M. Metodologia da Pesquisa-ação. 13a ed. Cortez, São Paulo, 2004.

THOMPSON, J. D. Organizations in Action. New York: Mc Graw-Hill. 1967.

TORMA-KRAJEWSKI, J.; STEINER, L.; LEWIS, P.; GUST, P.; JOHNSON, K.. Implementation of an ergonomics process at a U.S. surface coal mine. In: International Journal of Industrial Ergonomics, vol. 37, n. 2, p. 157-167, 2007.

U.S. BUREAU OF LABOR STATISTICS. Nonfatal occupational injuries and illnesses requiring days away from work, 2007. Disponível em: http://www.bls.gov/news.release/osh2.nro.htm. Acesso em: 17 de maio de 2009.

VERHAEGEN, P.; SALTHOUSE T. A. Meta-Analyses of Age Cognition Relations in Adulthood. Estimates of Linear and Nonlinear Age Effects and Structural Models. In: Psychological Bulletin, vol. 122, n. 3, p. 231-249, 1997.

VILLENEUVE, J.; REMIJN, S.L.M.; LU, J.; HIGNETT, S.; DUFFY, A.E. Ergonomic Intervention in hospital architecture. In: PIKAAR, R. (Hrsg.) ; KONINGSVELD, E. (Hrsg.) ; SETTELS, P. (Hrsg.): Meeting Diversity in Ergonomics. Amsterdam : Elsevier, 2007. 
VOORBIJ, A., STEENBEKKERS, L. The composition of a graph on the decline of total body strength with age based on pushing, pulling, twisting and gripping force. In: Applied Ergonomics, vol. 32, p. 287-292, 2001.

WEBER, M. Economia e sociedade: fundamentos da sociologia compreensiva. Brasília Universidade de Brasília São Paulo Imprensa Oficial do Estado de São Paulo, 2v., 2004. (Original 1922)

WISNER, A. Antropotecnologia. Rio de Janeiro, 2004.

ZALK, D. M. Grassroots Ergonomics: Initiating an Ergonomics Program Utilizing Participatory Techniques. In: Annals of Occupational Hygiene, vol. 45, n. 4, p. 283-289, 2001.

ZARIFIAN, P. As novas abordagens da produtividade. In: SOARES, R. M. S. M. Gestão da empresa, automação e competitividade: novos padrões de organização e de relações de trabalho, Brasília, IPEA/IPLAN, 1990. 


\section{9 - ANEXOS}

\section{ANEXO A: Definições de participar e envolver.}

FONTE: (http://michaelis.uol.com.br/moderno/portug ues/index.php. Acesso em: 15 outubro 2010$)$

\section{Par.ti.ci.par}

(lat participare) vtd 1 Comunicar, fazer saber, informar: Participamos nossa mudança. Participou ao chefe o motivo de sua ausência. vti. 2 Ter ou tomar parte em: "...participa comigo dos trabalhos do Evangelho, segundo a virtude de Deus" (2ª . Epístola a Timóteo, 1, 8 - tradução do Padre Matos Soares). Participaria dos ensinamentos secretos pela iniciação. vti 3 Associar-se pelo pensamento ou pelo sentimento; solidarizar-se: "...do sentimento de temor, que sobressaltava Inocência, também participava Cirino" (Visconde de Taunay). vti 4 Ter natureza ou qualidades de: $O$ filho participa da índole paterna. vti 5 Comunicar-se com: Participar com parentes, com amigos de outras cidades.

\section{En.vol.ver}

(lat involvere) vtd e vpr 1 Enrolar(-se), embrulhar(-se), meter(-se) dentro de invólucro: Envolvera o rosto num véu. Tiritando de frio, envolveu-se nos cobertores. vtd 2 Servir de invólucro a: Um canudo envolvia o documento. vtd 3 Esconder, dissimular: Envolveu a paixão numa aparência de desdém. vtd 4 Abranger: Esta função ainda envolve outras responsabilidades. vtd 5 Cercar, rodear, circundar: "...a poeirada fina envolvia as figuras, dava-lhes um tom neutro" (Eça de Queirós). vtd 6 Comprometer, enredar: "A injúria deste cristianismo caçador de homens cujas preces, Deus da bondade e do perdão, te envolvem na cumplicidade dos sacrifícios mais atrozes" (Rui Barbosa). vpr 7 Entremeter-se, incluir-se, comprometer-se: Envolver-se em negociatas. vpr 8 Resguardar-se, salvaguardar-se: "Envolveurse na sua dignidade" (Morais). vpr 9 Anuviar-se, toldar-se (o céu, o dia, o tempo). 


\section{ANEXO B: Roteiro da entrevista aos gestores do hospital.}

Nome - Cargo - Área - E-mail - Data.

DADOS GERAIS SOBRE A AREA:

Funcionários:

Afastamentos de longo prazo:

Funcionários com restrições do SESMT:

Atividades principais:

O QUE É ERGONOMIA?

Definição:

Cuida de (excluir aqueles que não são discutidos pelo entrevistado):

- Ambiente e layout

- Equipamentos

- Biomecânica e posturas

- Estresse e distúrbios psicológicos

- Nível organização

- Ligado a atividade

- Relações interpessoais

- Relações com outros departamentos

EXISTEM DIFICULDADES DE TIPO ERGONOMICO NA AREA?

A área é muito critica?

CONHEÇE AÇÕES DE TIPO ERGONOMICO QUE ESTÃO SENDO

DESENVSOLVIDAS NO HU-USP?

Trabalho "Grupos de treinamento e capacitação":

Trabalhos de microergonomia conseqüente ao grupo:

Trabalho LER-DORT:

Comitê de melhorias:

Outro (fisioterapia ou trabalhos de graduação)

Quais os resultados?

O trabalho na área melhorou no tempo (ligação com as ações de tipo ergonômico)?

ENVOLVIMENTO PESSOAL SOBRE ASSUNTOS ERGONOMICOS NO HUUSP.

Reativa o proativa? Precisa de ajuda externa?

Seria autônoma numa eventual nova ação estruturada?

Melhorou o cuidado?

O que faria no caso de novas queixas de ergonomia?

DIFICULDADES DE TIPO ERGONOMICO NA COMPRA DE EQUIPAMENTOS E MATERIAL

Autonomia pode levar a escolhas certas? Ou precisa apoio da organização?

Como resolver as dificuldades? 


\section{ANEXO C: Roteiro da entrevista dos participantes ao "Grupo de Melhorias".}

Nome - Cargo - Área - E-mail - Data.

Quais os objetivos do "Comitê de Melhorias"?

O que acha das ações desenvolvidas no "Comitê de Melhorias"? (Positivonegativo?)

O que espera no futuro do "Comitê de Melhorias"?

Qual o grau de envolvimento pessoal no "Comitê de Melhorias" até o instante?

Qual o grau de envolvimento pessoal no "Comitê de Melhorias" no futuro?

Qual o grau de envolvimento dos outros componentes do "Comitê de Melhorias"?

Qual o grau de envolvimento da instituição no "Comitê de Melhorias"?

Qual o grau de envolvimento da equipe da Escola Politécnica no "Comitê de Melhorias"?

Sugestões: 
ANEXO D: Roteiro da entrevista a quem participou do "Grupo de treinamento e Capacitação".

Nome - Cargo - Área - E-mail - Data.

Como entrou a fazer parte do "Grupo de treinamento e capacitação"?

Acha de ter ampliado os conhecimentos?

Sobre o trabalho pratico final...

Consegue aplicar os novos conhecimentos na própria área?

Qual o suporte da superintendência (ou dos diretores do próprio departamento)?

Conhece ações de tipo ergonômico que estão sendo desenvolvidas no HUUSP alem e depois do curso?

Sugestões: 


\section{ANEXO E: Dados sobre funcionários com restrições e afastamentos a longo prazo no HU-USP.}

\begin{tabular}{|c|c|c|c|c|c|c|}
\hline Área & Serviço & $\begin{array}{c}\mathrm{N} . \\
\text { Funcionários }\end{array}$ & $\begin{array}{c}\text { Com } \\
\text { restrições }\end{array}$ & $\begin{array}{c}\% \\
\text { Restr. }\end{array}$ & $\begin{array}{c}\text { Afastamentos } \\
\text { a L.P. }\end{array}$ & $\begin{array}{c}\% \\
\text { Afast. }\end{array}$ \\
\hline Enfermagem & Endoscopia & 25 & 3 & $12,0 \%$ & 1 & $4,0 \%$ \\
\hline Enfermagem & Alojamento conjunto & 49 & $\mathrm{NI}$ & $\mathrm{NI}$ & 1 (1 psiq.) & $2,0 \%$ \\
\hline Enfermagem & PS & 54 & 11 & $20,4 \%$ & 1 & $1,9 \%$ \\
\hline Enfermagem & CME & 33 & 6 & $18,2 \%$ & 0 & $0,0 \%$ \\
\hline Enfermagem & Clinica Medica & 58 & 10 & $17,2 \%$ & 2 (1 psiq.) & $3,4 \%$ \\
\hline Enfermagem & Ambulatório & 18 & 8 (3 psiq.) & $44,4 \%$ & 0 & $0,0 \%$ \\
\hline Enfermagem & Centro obstétrico & 44 & 3 & $6,8 \%$ & 1 & $2,3 \%$ \\
\hline Enfermagem & Clinica Cirúrgica & 61 & 11 (2 psiq.) & $18,0 \%$ & 5 (2 psiq.) & $8,2 \%$ \\
\hline Enfermagem & Pediatria & 55 & 3 & $5,5 \%$ & 2 (1 psiq.) & $3,6 \%$ \\
\hline Enfermagem & UTI adulto & 64 & 6 & $9,4 \%$ & 0 & $0,0 \%$ \\
\hline Enfermagem & UTI pediátrica & 52 & 0 & $0,0 \%$ & 1 & $1,9 \%$ \\
\hline Enfermagem & Apoio educacional & 5 & 1 & $20,0 \%$ & 0 & $0,0 \%$ \\
\hline Enfermagem & Clinica Cirúrgica & 41 & $\mathrm{NI}$ & $\mathrm{NI}$ & 0 & $0,0 \%$ \\
\hline Enfermagem & Berçário & 41 & 7 (1 psiq.) & $17,1 \%$ & 0 & $0,0 \%$ \\
\hline Enfermagem & Imagenologia & 73 & 3 & $4,1 \%$ & 0 & $0,0 \%$ \\
\hline Enfermagem & PS infantil & 28 & $4(2$ psiq. $)$ & $14,3 \%$ & 1 (1 psiq.) & $3,6 \%$ \\
\hline Enfermagem & Laboratório clinico & 74 & 5 & $6,8 \%$ & 0 & $0,0 \%$ \\
\hline Enfermagem* & TOTAL & $775\left(685^{*}\right)$ & 81 (8 psiq.) $^{*}$ & $11,8 \% *$ & 15 (6 psiq.) & $1,9 \%$ \\
\hline Medico & PS & 70 & 0 & $0,0 \%$ & 0 & $0,0 \%$ \\
\hline Medico & Clínica Medica & 66 & 0 & $0,0 \%$ & 0 & $0,0 \%$ \\
\hline Medico & Clinica Obstétrica & 29 & 0 & $0,0 \%$ & 0 & $0,0 \%$ \\
\hline Medico & UTI adulto & 12 & 0 & $0,0 \%$ & 0 & $0,0 \%$ \\
\hline Medico & Clinica pediátrica & 43 & 0 & $0,0 \%$ & 0 & $0,0 \%$ \\
\hline Medico & Endoscopia & 7 & 0 & $0,0 \%$ & 0 & $0,0 \%$ \\
\hline Medico & Clinica pediátrica & 10 & 0 & $0,0 \%$ & 0 & $0,0 \%$ \\
\hline Medico & Clinica Cirúrgica & 37 & 0 & $0,0 \%$ & 0 & $0,0 \%$ \\
\hline Medico & TOTAL & 274 & 0 & $0,0 \%$ & 0 & $0,0 \%$ \\
\hline SAME & Arquivo M. e Estatistica & 17 & 2 & $11,8 \%$ & 0 & $0,0 \%$ \\
\hline SAME & Ambulatório & 25 & 3 & $12,0 \%$ & 1 & $4,0 \%$ \\
\hline SAME & Registro & 34 & 4 & $11,8 \%$ & 0 & $0,0 \%$ \\
\hline Higienização espec. & Higienização espec. & 103 & 29 & $28,2 \%$ & 4 & $3,9 \%$ \\
\hline Nutrição e Diet. & Nutrição e Diet. & 112 & $22(1$ psiq. $)$ & $19,6 \%$ & 3 & $2,7 \%$ \\
\hline SAME, Hig. e Nutri. & TOTAL & 291 & 60 (1 psiq.) & $20,6 \%$ & 8 & $2,7 \%$ \\
\hline Almoxarifado & Almoxarifado & 20 & 2 & $10,0 \%$ & 0 & $0,0 \%$ \\
\hline Compras & Compras & 7 & 0 & $0,0 \%$ & 0 & $0,0 \%$ \\
\hline Farmácia & Farmácia & 45 & $\mathrm{NI}$ & $\mathrm{NI}$ & 1 & $2,2 \%$ \\
\hline Finança Social & Finança Social & 12 & 0 & $0,0 \%$ & 0 & $0,0 \%$ \\
\hline Fisioterapia & Fisioterapia & 15 & 0 & $0,0 \%$ & 0 & $0,0 \%$ \\
\hline Informática & Informática & 18 & 4 & $22,2 \%$ & 0 & $0,0 \%$ \\
\hline Manut. e eng. Hosp. & Manut. e eng. Hosp. & 43 & $\mathrm{NI}$ & $\mathrm{NI}$ & 0 & $0,0 \%$ \\
\hline Serv. Social & Serv. Social & 18 & 0 & $0,0 \%$ & 0 & $0,0 \%$ \\
\hline Transporte & Transporte & 26 & 0 & $0,0 \%$ & 0 & $0,0 \%$ \\
\hline Zeladoria & Zeladoria & 60 & 0 & $0,0 \%$ & 0 & $0,0 \%$ \\
\hline OUTROS & TOTAL & $264\left(176^{*}\right)$ & $6^{*}$ & $3,4 \% *$ & 1 & $0,4 \%$ \\
\hline TOTAL & & $1604\left(1426^{*}\right)$ & $147^{*}$ & $10,3 \% *$ & 24 & $1,5 \%$ \\
\hline
\end{tabular}




\section{ANEXO F : Falas coletadas durante as entrevistas semi-estruturadas}

Falas 1, sobre o envolvimento em projetos de melhoria das condições de trabalho do trabalhador da área operativa: "Mudou um pouco a visão em relação aos trabalhadores: precisa considerar o trabalhador antes de qualquer julgamento". "Mudou o olhar. Cada móvel que a gente adquire existe uma preocupação que nunca tivemos... Na compra de equipamentos de trabalho as decisões são tomadas juntas"

Fala 2, sobre o novo olhar ergonômico dos Terapeutas Ocupacionais e Fisioterapeutas: "A gente, empiricamente, fazia uma análise ergonômica, porém dávamos uma volta maior do que nos foi ensinado".

Falas 3, sobre o novo olhar ergonômico dos Terapeutas Ocupacionais e Fisioterapeutas: "Uma coisa que chamou muito atenção é que na hora da admissão de um novo funcionário, de acordo com a função e atividade que exerceria, se esperava que fosse um homem porque a gente precisa de um certo esforço físico. Agora penso que cada trabalho teria que ser feito por todos os trabalhadores. Com algum equipamento as atividades poderiam ser feito por qualquer pessoa, independente do sexo, e constituição física". "Ampliou no sentido de conhecer melhor a forma de trabalhar de quem trabalha na área e de conhecer a problemática do hospital como um todo. Estavam representados vários setores, e o fato de cada dupla apresentar o seu trabalho, deu a possibilidade de conhecer as problemáticas de cada setor. Aquele sentimento, de falar que o próprio setor é o mais prejudicado, foi superado. Não tem uma coisa que fica no escanteio, todos os departamentos tem problemas e precisam de melhorias. Todo mundo esta no mesmo barco, e todo mundo esta batalhando. Aumentou e fortaleceu o grupo."

Falas 4, sobre os limites dos trabalhadores da área operativas em propor mudanças ergonômicas: Entre as verbalizações: "Existem problemas de tipo ergonômico na área, mas muitas vezes não são no meu alcance e não conseguiria resolve-los sem o suporte dos superiores. Não tenho força para agir sozinha". "Não existem requisições oficiais para fazer um trabalho dedicado (mas o curso deu base para fazê-la). Eu teria condições se solicitado". "O chefe da minha seção esta muito aberta para ajudar. $O$ meu envolvimento é em fazer sugestões, mas é muito raro que as mudanças dependem de mim. Tudo depende também de verba e do tempo".

Fala 5, sobre os limites dos gestores em propor mudanças ergonômicas: "Eu posso ate sugerir, comentar, mas não vai ter o mesmo peso que do comitê. Por exemplo se uma pessoa vai pegar um peso, eu sei como orientar, qual a posição que precisa ter para fazer determinada atividade, pausa, para minimizar algum dano".

Fala 6, sobre a dificuldade de estudar processos com um olhar interno e viciado da rotina de trabalho: "Por pequenas melhorias existe a preocupação no aspecto ergonômico, mas é difícil para quem trabalha na área fazer um estudo estruturado: 0 
olhar fica viciado, mas também ficando na área não se consegue destinar tempo a uma analise focada, tendo cada vez outras coisas as quais se da maior prioridade".

Fala 7, sobre a atitude proativa de um gestor: . "Eu dependo muito da Administração do HU. As solicitações foram já encaminhadas... Tudo aquilo que depende de mim já foi feito. O que envolve reforma já foi encaminhado, e algumas coisas já estão sendo feitas. Muito do trabalho manual será automatizado daqui a um ano com a instalação de lavadoras no expurgo".

Fala 8, de uma pessoa do GTC com avaliação neutra sobre o suporte da organização depois do curso: "Eu não vejo negativamente a posição da Superintendência, simplesmente minimizaram os efeitos de uma sensibilização da instituição com assuntos de melhoria das condições de trabalho... Eles não tinham idéia do que era, mexeram num vespeiro... Faltou estratégia e planejamento... Entendo também que é difícil para o empregador mexer em todo".

Falas 9, de duas pessoas do GTC com avaliação muito ruim sobre o suporte da organização depois do curso: "A gente fez, fez, fez, mas acabou". "Parece que tudo morreu, tudo acabou".

Fala 10, sobre o sentimento de um participante do GTC no meio do curso: "Durante o curso sentimos: o que vamos fazer depois do curso de capacitação? Aonde vamos atuar?".

Fala 11, sobre a visão de um entrevistado do GTC sobre as ações ergonômicas desenvolvidas pelo HU-USP: "A visão que teve é que antes do curso é aquele fogo de palha de uma iniciativa que trouxe visibilidade de fora com o hospital que esta inovando, olhando estas pessoas... Quando foi deixada a posição mais operante eles começaram enxergar que não tem só a fachada e ai deram uma apagada, uma sumida, assim que se perguntaram: Entramos nessa para ter visibilidade, mas temos que responder a esta demanda, e agora?".

Falas 12, sobre comentários do mix de pessoas participantes do GTC: Havia uma barreira de conhecimento e na maneira em se expressar. Não consegui compreender para poder aprender". "As pessoas da área da fisioterapia estavam bem envolvidos, mas eu e outros enfermeiros não. Quando começamos entender um pouco de ergonomia o curso acabou".

Falas 13, de queixas dos participantes sobre o curso no GTC: ("As pessoas se perderam um pouco e depois de seis meses a turma resolveu pedir para diminuir a carga de trabalho". "As aulas eram muito longas e a didática deixava a desejar. Se perdia no assunto e o fato de apresentar todas as vezes os trabalhos de todos os grupos demorava e cansava".

Fala 14, sobre falta de incentivo á participação no GTC: “... e mesmo se precisa ficar mais tempo para fazer estas atividades ajudando o hospital, o salário é o mesmo" 
Fala 15, sobre a importância de ter um coordenador no GTC: "O ser humano é preguiçoso de natureza e se não tem ninguém que puxa o assunto vai ficar ser esquecido. Se fosse pergunto a qualquer pessoa se tem tempo para ceder ao hospital, todo mundo falaria que esta ocupadíssimo).

Falas 16 sobre o GTC, de gestores que conhecem bem tal proposta no hospital: "Acho muito importante que a enfermagem tenha participado nisso para cobrar a instituição". "Aonde foram feitos estudos, trouxe bom resultados". "Este grupo veio solidificar as ações já empreendidas para limitar problemas ergonômicos e resultou em um maior esforço do departamento e do hospital como um todo".

Falas 17 sobre a importância do papel da ergonomia nas melhorias das condições de trabalho nos últimos anos no HU-USP: "Participar desta proposta ajudou em possibilitar escolhas mais cuidadosas no ato da compra, em gerenciar melhor as rotinas dos funcionários com restrições, a rotina de trabalho é discutida juntos e em melhorar a escuta do trabalhador, é da sugestão deles que podem chegar muitas melhorias, as vezes eles tem visões legais". "Eu percebi que no auge do curso tinha um olhar ergonômico melhor. Já agora vejo menos pessoas discutindo neste aspecto. Mudou um pouco, mas não como esperado". "As condições de trabalho na área melhoraram bastante no tempo e os trabalhos de ergonomia chegaram a reforçar e a dar uma argumentação melhor. Ajudou em conseguir resultados tendo trabalhos e docentes por trás. As mudanças foram feitas no decorrer da realização dos trabalhos. A instituição se sente em obrigação. Mudou a mentalidade das pessoas".

Fala 18, que resume o pensamento geral de médicos e enfermeiras sobre a figura da responsável de compras das próprias áreas: " $E$ ' muito bom ter uma pessoa especifica na enfermagem que cuida integralmente da parte de compras de materiais e que tem a preocupação extrema com a qualidade de nossos insumos. De certa forma ela é a intermediadora das solicitações dos setores dentro do departamento, porque tem o conhecimento técnico para discutir, diferente do que ocorre na questão ergonômica, aonde não temos uma pessoa que sirva de referencia técnica".

Fala 19 sobre o problema dos gestores em fazer especificações completas nas licitações: "Eu tenho idéias do que eu quero, mas não consigo encaixá-lo em especificações completas.".

Fala 20, sobre um problema ergonômico na compra de equipamentos: "Existe pouca iniciativa das pessoas; na hora das mudanças eles esperam as decisões das chefias em vez de demonstrar iniciativa em realizar as mudanças".

Fala 21, sobre a limitação do teste antes de comprar com licitação: "Não é só testar 10 minutos que não se percebe o real conforto. E' no dia-dia que você começa perceber (verbalização de um chefe sobre a compra de cadeiras na própria área".

Fala 22, com um exemplo indicando um dos impactos causados da grande demora no processo de compra: "Partindo da necessidade de trocar as cadeiras, ou pelo menos 
os estofados que depois de oito anos estavam de uma aparência péssima, fui enfrentar uma escolha: ou trocar completamente as cadeiras, ou permanecer com as mesmas, mas trocando o estofado. A escolha caiu sobre a segunda opção. Fator determinante na escolha foi o tempo de atuação das duas alternativas: a primeira teria demorado bem mais da segunda que mesmo assim necessitou de um ano para ser atendida e concluída.... Não percebemos na hora da decisão que o desconforto da apresentação do tecido e a desarmonia visual, criticas para um serviço a forte contato com os clientes, foi mais determinante que a escolha de uma alternativa mais demorada, mas que teria ajudado os trabalhadores a ter um melhor conforte".

Falas 23, sobre as limitadas opções de ferramentas no mercado: “...não há muita opção. As empresas fornecedoras já se preocupam com ergonomia e nós não temos como influir... Não há possibilidade de escolha do equipamento estabelecendo a ergonomia como parâmetro principal. Em tese, todos são ergonômicos". "Os equipamentos já são padronizados assim que na hora de fazer a requisição de compra é inútil especificar muito. Se é pedida alguma coisa fora do padrão, ou ninguém vende, ou o preço fica muito alto".

Fala 24, sobre os benefícios em envolver trabalhadores da área operativa em projetos de melhoria: "Compra de equipamentos e mudanças estruturais são concordadas com toda a equipe interessada. O envolvimento dos trabalhadores é essencial, porque eles conhecem as necessidades e dificuldades que enfrentam para desenvolver sua atividade. As pesquisas de opinião levam a compra de equipamentos quase personalizados. Isso nem sempre é positivo, precisaria de uma orientação. Acontece que alguma cadeira, por exemplo, é comprada por indicação do trabalhador o qual num segundo instante não a utiliza porque pouco confortável. Antes da compras os materiais são experimentados e avaliados por parte dos trabalhadores. Tem exemplos de sucesso de como o palpite dos trabalhadores puderam melhorar projetos de layout feitos por parte dos engenheiros do trabalho (externos a realidade)". "(Falando sobre a compra de carrinhos) ...eu dou as limitações, por exemplo que o equipamento seja de metal por questões de higiene, mas as escolhas são dos funcionários. Os funcionários não sempre são completamente cuidadosos na escolha de novo material pensando em assuntos ergonômicos, também se nos últimos anos melhorou muito". 


\section{ANEXO G: Características do processo de compra do HU-USP.}

Entender o processo técnico de compras do hospital é necessário para entender onde o pesquisador pode atuar para melhorá-lo e conseguir embutir melhorias de tipo ergonômico. Conhecer os limites, em particular, vai permitir numa fase sucessiva da análise, delinear os vínculos que a organização tem que valorizar e quais podem inviabilizar muitas soluções de mudança.

Como antecipado, o Hospital Universitário é uma instituição publica, e como tal precisa que seja gerenciado com a máxima transparência permitindo que cada atividade possa ser controlada por parte das autoridades publicas para não ter abusos de administração. As compras, para os processos envolvidos nela e a utilização de verba publica, é uma das áreas que precisa ter mais controle. Para prevenir qualquer abuso financeiro foi introduzido no processo de compra de empresas públicas brasileiras a obrigatoriedade de abrir licitações no ato de adquirir materiais de valor médio-elevado no mercado, e outros processos para permitir a traçabilidade e a transparência em compras emergenciais e de baixo valor. A Licitação é o procedimento administrativo para contratação de serviços ou aquisição de produtos executado pelas entidades que façam uso da verba pública.

Precisar mostrar transparência no próprio processo de compra, e aplicar mais procedimentos, come aqueles derivados da uma licitação, na prática engessam tal processo e provoca um alto impacto sobre a possibilidade de adquirir, ou não, o equipamento mais adequado para o trabalho dos funcionários do HU-USP

\section{Atores envolvidos no processo de compra}

Antes de descrever o processo de compra do HU foi necessário saber quais são os atores envolvidos no processo e aonde eles atuam.

Trabalhadores da área operacional: eles são os principais utilizadores de materiais e equipamentos durante os próprios procedimentos de trabalho. São eles os primeiros a terem controle sobre as quantidades e a disponibilidade de materiais necessários a um ótimo funcionamento dos serviços, sobre o estado dos equipamentos e sobre o aparecer de novas necessidades. Eles são os principais consumidores, e por isso a demanda de compra parte deles.

Chefias।Gestores: Os gestores de serviços e de departamentos têm a função de ser os catalisadores de todas as necessidade de compras expressas por parte dos 
próprios trabalhadores. Eles têm a tarefa de coletar e juntar todas as requisições de compras de materiais para poder entregar um documento único e controlar que não haja desperdício. Os gestores asseguram atualmente também um papel importante em propor a compra de novos materiais ou equipamentos com valor médio-alto no mercado decorrentes seja de novas necessidades ou de novos processos, seja para melhorar os procedimentos preexistentes.

Responsáveis de compras: Nem em todos os departamentos as chefias des envolvem o papel de catalisador da demanda de compras: dependendo do tamanho da unidade se faz necessário para as chefias a delegação da gestão de compras para uma pessoa específica do mesmo departamentolserviço. Este é o caso do Departamento do Laboratório Clinico e dos departamentos da Enfermagem e Médico. Neste caso, este funcionário tem a tarefa de juntar todas as requisições, e de buscar soluções interessantes partindo das necessidades levantadas. Dada a especialização, esta figura é muito interessante porque permite a padronização de alguns itens, uma dedicação exclusiva para buscar soluções melhores e originais e a difusão de eventuais melhorias em equipamentos em mais áreas.

NUGEM: é um grupo implantado a nível estratégico composto por enfermeiros e médicos que avalia os materiais que entram no hospital impossibilitando a compra de produtos não necessários aos tipos de serviços oferecidos no HU-USP. Eles analisam exclusivamente as requisições de compra de novos materiais e novos equipamentos.

Grupo de investimentos: é um grupo interno composto por elementos da superintendência e do setor financeiro que define a prioridade das compras de todo o hospital em relação à verba disponível cada ano. Aquele que não pode ser comprado num ano por menor prioridade passa a ser considerado o ano sucessivo. Existe porém já um plano quadrienal para compra de equipamentos de grande porte para conseguir alem de priorizar, também planejar as requisições de todas as áreas.

Setor de compras: O setor de compras do HU é um setor interno ao hospital com a função de gerenciar os processos administrativos de aquisição. $\mathrm{Na}$ prática, os funcionários de tal área executam fisicamente a compra partindo das necessidades filtradas do hospital e viram os interlocutores entre todos os departamentos internos com os fornecedores externos. 


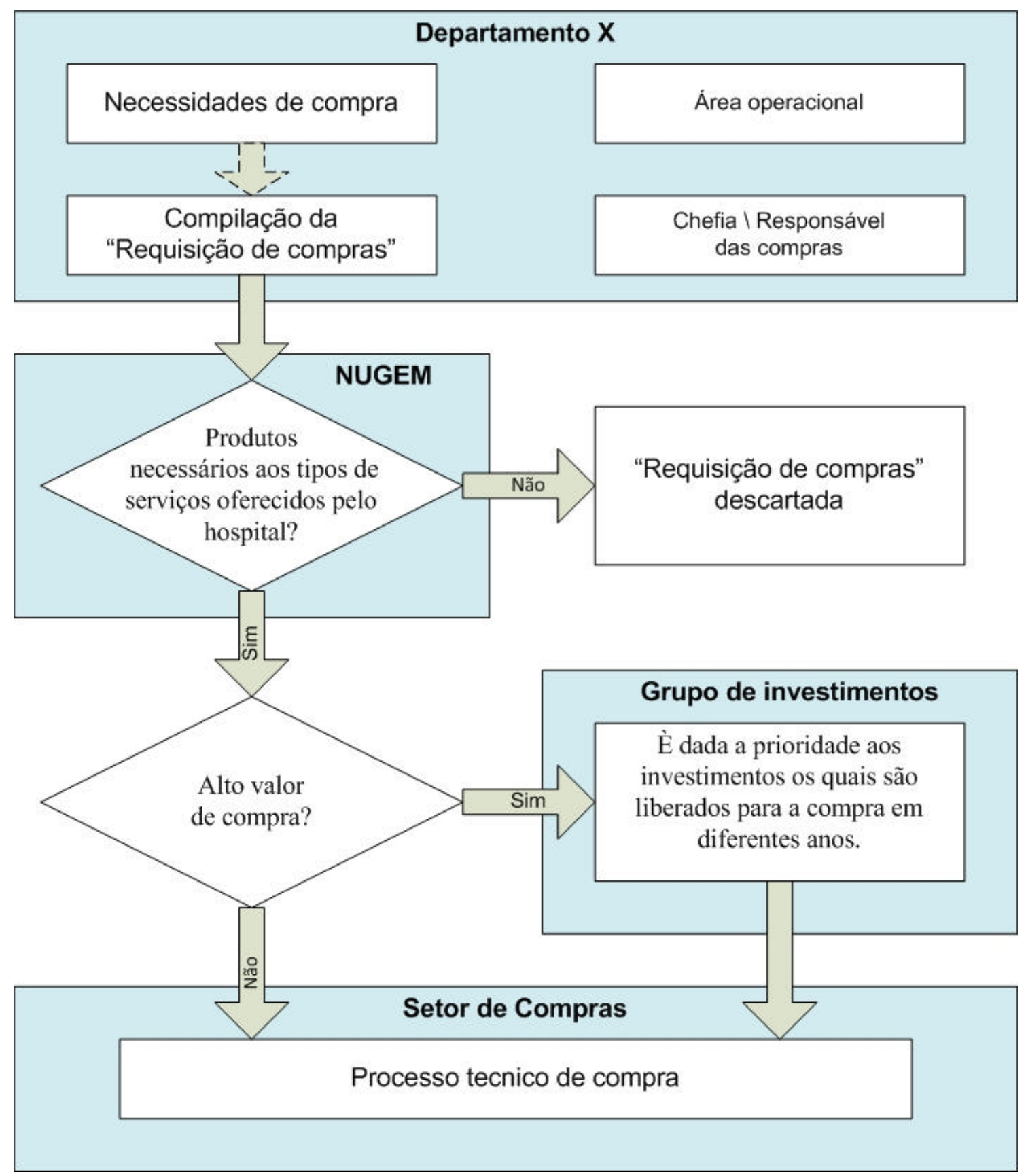

Figura A1 - Fluxo do documento "Requisição de compra”.

Fonte: Elaboração própria a partir dos dados de pesquisa de campo.

\section{A "Requisição de compras"}

A "Requisição de compras" é a única ferramenta utilizada para levantar as necessidades de compra de todos os departamentos. Este é um formulário preenchido ao nível das chefias, ou dos responsáveis de compra com o objetivo de agregar as necessidades de compra de itens iguais nos diferentes departamentos, levantar todas as informações técnicas dos materiais pedidos e as especificações dos produtos a 
serem comprados, e de introduzir também a motivação da compra.. É importante ressaltar que este documento não é utilizado para a compra de material habitual o qual é gerenciado em estoque (come descrito no próximo sub-capitulo). Deste é feita a requisição de compra exclusivamente na primeira vez e sucessivamente é cadastrado num sistema informático e sempre comprado cada mês.

$\mathrm{Na}$ figura A1 é apresentado o fluxo da "Requisição de compra" que representa a maneira de levantar as necessidades até a compra dos materiais aptos a satisfazêlas.

\section{Processo técnico de compras do HU-USP (fluxograma)}

Entrando numa análise mais detalhada, em seguida é apresentado o processo técnico de compras. Existem duas modalidades gerais de gestão logística interna das compras (figura A2). Estas dependem da habitualidade da compra e, conseqüentemente, da tipologia do produto, e são:

- a estoque. Nesta categoria são incluídos cerca de 3000 itens que são tipicamente de uso continuo e de alto turnover (como por exemplo materiais descartáveis e medicamentos). Estes são estocados no almoxarifado (ou no setor da farmácia) e as quantidades são controladas semanalmente. Do lado gerencial, até hoje, a reposição é feita seguindo uma avaliação da demanda mensal, resultado da soma de cotas fixas mensais de consumo que cada setor prevê. Estas cotas são definidas inicialmente junto ao NUGEM enquanto cada alteração é gerenciada autonomamente por cada setor e é informada diretamente ao almoxarifado o qual ás re-cadastra no próprio sistema informático. A tarefa principal do setor de compras nesta modalidade é aquela de formular pedidos de compra mensais resultante da soma de todas as cotas. Os trabalhadores do setor das compras não são responsáveis em definir qual produto comprar, nem em controlar a alteração das quantidades nas cotas. Existe um projeto, já começado com pilotos no centro cirúrgico e na farmácia e que vai ser completado em 1-2 anos, aonde os pedidos de compras irão ser gerenciadas através um sistema informático que funciona com previsão de demanda partindo do histórico e dos forecasts. No futuro então, serão formulados pedidos de compra uma vez que as quantidades de materiais descem abaixo do estoque de segurança.

- por pedido (através requisições de compra). Esta modalidade é típica da compra de equipamentos e novos materiais (também de produtos que substituirão outros já presentes no almoxarifado) a qual precisa passar do grupo NUGEM. Para gerenciar esta modalidade, nos últimos anos foi definida uma janela temporária de um mês no ano aonde os setores podem entregar pedidos de aquisição. Antes a compra ocorria 
de jeito continuo, e a criação desta janela permitiu possibilitar as compras por prioridade (tendo um budget anual limitado e pré-estabelecido destinado a compras), ajudando em juntar as quantidades de muitos pedidos de mesmos produtos (que ajuda indiretamente na diminuição dos preços e numa melhor administração dos tempos) e disciplinando as pessoas no envio de tais pedidos (forçando as pessoas a se programar). A janela normalmente é aberta no meio do ano, sendo os pedidos, uma vez aprovados, comprados só no ano sucessivo. Em casos extraordinários é possível ter exceções uma vez que é enviada uma justificativa. Outros eventos não previsíveis, como o exemplo de quebras de equipamentos não únicos (ex de cadeiras) são geralmente gerenciados antecipando os acontecimentos, através contratos por exemplo de pregão por "registro de preço". Uma vez que as solicitações são aceitas pelo NUGEM, dependendo do valor da compra, se alto, o pedido precisa passar para o "grupo de investimento".

Com foco na gestão do processo de suprimento ao externo, as modalidades de gestão das compras são diferentes dependendo do preço (valor). Uma vez que os pedidos de compra chegam no departamento responsável, estes são enviados para o comprador, uma figura interna que através uma busca entre pelo menos três empresas chega a entregar um orçamento "indicativo". O valor do orçamento vai definir como será realizada a compra. Três modalidades:

- Compras por adiantamento e para emergências. Os objetos ou matérias adquiridos com esta modalidade geralmente são pequenos, com baixo volume, não apresentam geralmente estoque e, sobretudo tem um preço baixo. O que caracteriza este tipo de compra é a possibilidade de comprar o produto diretamente da qualquer fornecedor já no ato do pedido. Se o produto nunca foi adquirido anteriormente é normal receber uma amostra para avaliar a qualidade do produto com o fim, se atende todos os parâmetros, de homologá-lo. Para as sucessivas compras esta marca terá a precedência.

-Licitação / pregão. É obrigatória para pedidos de compra que superam o valor de $8000 \mathrm{R} \$$. Nesta tipologia é necessário abrir um processo de compra publico entre varias empresas que vendem os produtos com as características requeridas. $O$ ganhador de tal pocesso resultará aquele que apresenta a oferta mais vantajosa, normalmente em termo de melhor preço. 


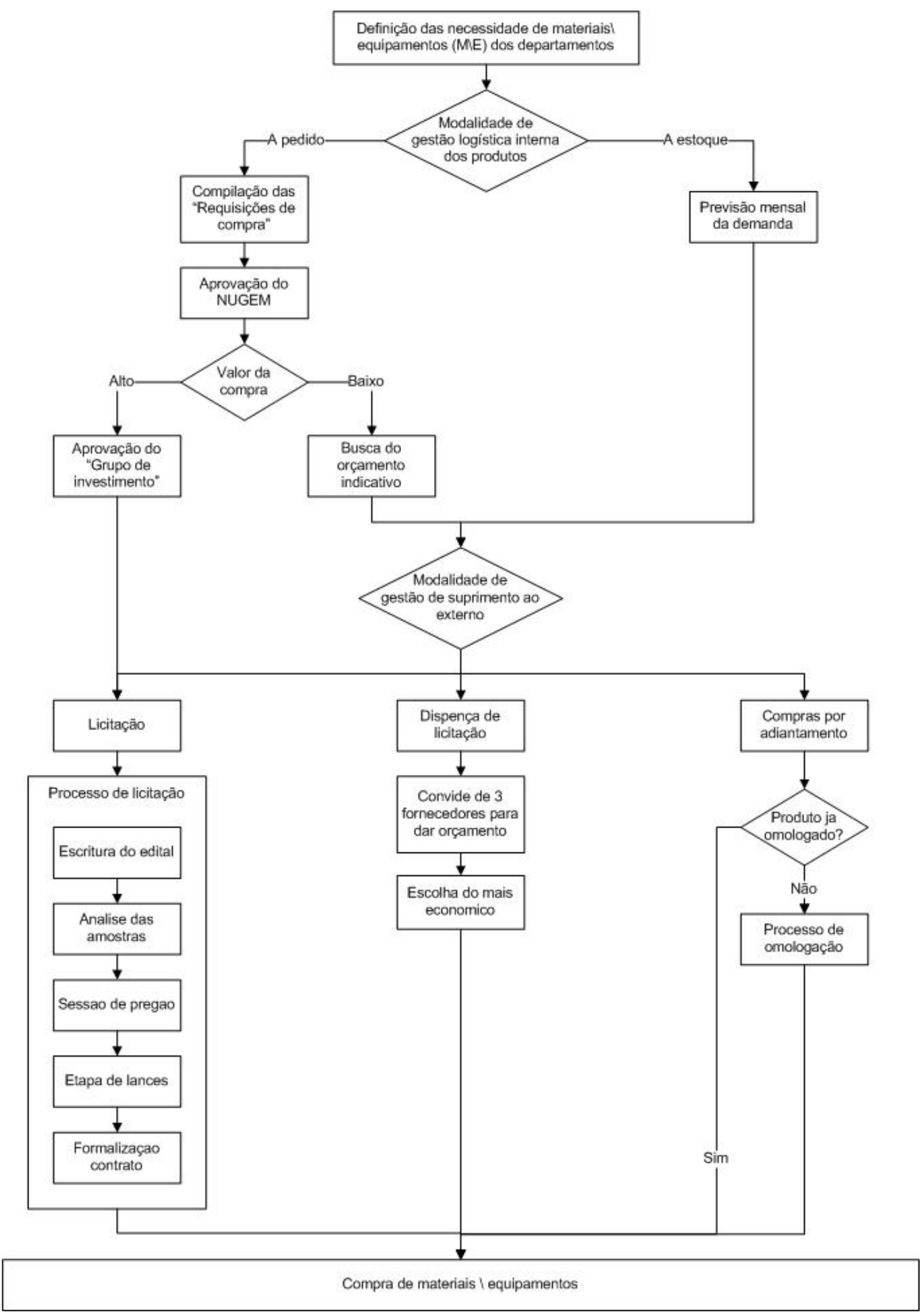

Figura A2 - Processo técnico de compras do HU-USP.

Fonte: Elaboração própria a partir dos dados de pesquisa de campo. 
Existem varias modalidades de licitação, reguladas através da lei n.8.666, de 21 de junho de 1993. No hospital universitário a mais utilizada é a de Pregão tipo "registro de preço". Uma vez terminada uma licitação, o ganhador vai fornecer o material comprado naquela licitação por um ano, sobre encomenda e com um preço préestabelecido. Esta é tipicamente utilizada por pedidos de grandes quantidades (geralmente de material de uso cotidiano aonde o reabastecimento é feito através previsão da demanda) ou de equipamentos de reposição continua (em seguida a pedidos de compras dos setores em todo o hospital). Outros tipos de licitações utilizadas no hospital são: convite, tomada de preço (que alem do preço na avaliação tem também um julgamento técnico, ex. na construção de um andar) e concorrência.

O processo de licitação demora na volta de 30 dias. O processo, descrito superficialmente é o seguinte: o comprador monta o processo de compra escrevendo um edital que define os parâmetros e condições requeridas por tais produtos, é aberta uma sessão de pregão, as propostas selecionadas vão para a etapa de lances, o menor lance será o vencedor e é formalizado um contrato. Entre o edital e a sessão, uma equipe técnica se reúne para analisar as amostras do produto pedido de cada fornecedor potencial com o objetivo de avaliá-lo, tais amostras se homologadas a empresa pode continuar no processo de licitação, se rejeitadas a empresa estará desclassificada.

O pregão é um modalidade administrativa mais recente de licitação, que proporciona mais agilidade ao processo de compras. A documentação dos fornecedores não é mais conferida e juntada antes do processo de seleção, mas é feito só depois e só com o vencedor.

- Dispensa de licitação. É a modalidade de compras para pedidos que chegam a um valor de até $8.000 \mathrm{R} \$$. Geralmente é típica da compra de materiais não são de uso cotidiano e de quantidade razoáveis. Alem disso, tal modalidade de compra permite o abastecimento do almoxarifado de um item que ainda está em processo licitatório.

O processo de compra neste caso não é publico, mas são convidados pelo menos três fornecedores potenciais a dar um orçamento, e o ganhador e aquele que apresenta as condições, normalmente de preço, melhores.

Enquanto a compra por adiantamento e para emergências permite de comprar em qualquer empresa que tenha nota fiscal, nas outras duas modalidades a legislação 
exige que as empresas entreguem todas as documentações que elas não estejam em falência e não tenha dividas com o estado. A empresa precisa provar isso.

\section{Avaliação ergonômica no processo de compra de materiais e equipamentos}

Atualmente não existe uma avaliação ergonômica estruturada dos materiais adquiridos do mercado. A iniciativa para levar em considerações os aspectos ergonômicos é deixada a iniciativa pessoal de cada chefia ou responsável de compra de cada departamento. Dependendo daquele que é especificado na requisição de compra e do detalhe da mesma depende a qualidade e a aderência das compras em satisfazer as próprias necessidades em termo técnico (permitir uma execução ótima do serviço) e de proporcionar ótimas condições de trabalho para os funcionários que vão utilizar estes produtos. Durante as licitações são as mesmas chefias ou responsáveis de compras que compõe a equipe técnica que testa os produtos e tem o puder de desqualificar eventuais produtos inadequados.

Os outros atores do processo de compra atualmente não incluem nas próprias atividades avaliações de tipo ergonômico. Os trabalhadores da área operacional raramente levantam idéias de melhoria ergonômica para os próprios equipamentos de trabalho e de qualquer jeito estas idéias são coletadas por parte das chefias e responsáveis de compra. O NUGEM avalia unicamente que não sejam comprados materiais e equipamentos que não sejam necessários a prestação dos serviços presentes no HU-USP, sem entrar então no mérito da funcionalidade dos mesmos. Como foi claro na entrevista com uma participante do grupo, o NUGEM não pode falar ao sujeito se a sua requisição é boa ou não, não podendo então opinar sobre a bondade do material \equipamento no aspecto ergonômico. O grupo de investimentos faz unicamente uma avaliação de prioridade econômica. Do seu lado o setor das compras cuida essencialmente do procedimento de compra em termos administrativos ou seja, partindo dos parâmetros do produto que chegam a ela através dos pedidos, ele executa a compra as melhores condições (normalmente de preço, partindo da especificações fixadas) do mercado.

Tudo depende então da qualidade das especificações, definidas nos pedidos dos responsáveis para as requisições de compra de cada setor do hospital. Se não chegam completas, tem boa probabilidade que os materiais comprados não sejam úteis para o requerente. Paralelamente as mesmas requisições podem não considerar especificadamente as condições de trabalho de quem vai utilizar estes materiais. 
No hospital, partindo da experiência da responsável do setor compras, mesmo tendo cuidado para considerar o bom conforto nos materiais pedidos, infelizmente não existe uma cultura que leva os setores a considerar o impacto de tais objetos nas atividades dos próprios trabalhadores em termo de saúde e bem estar. 